\title{
Assessing Integration Methodology (AIM): A Handbook for Measuring and Assessing the Integration of Family Planning and Other Reproductive Health Services
}

M. Estela Rivero-Fuentes

Saumya RamaRao

Population Council

Ricardo Estrada

Charlotte E. Warren

Population Council

Saiqa Mullick

Population Council

See next page for additional authors

Follow this and additional works at: https://knowledgecommons.popcouncil.org/departments_sbsr-rh

Part of the Demography, Population, and Ecology Commons, Family, Life Course, and Society Commons, Gender and Sexuality Commons, International Public Health Commons, Maternal and Child Health Commons, Medicine and Health Commons, and the Women's Health Commons How does access to this work benefit you? Let us know!

\section{Recommended Citation}

Rivero-Fuentes, M. Estela, Saumya RamaRao, Ricardo Estrada, Charlotte E. Warren, Saiqa Mullick, Ian Askew, Harriet Birungi, John Townsend, and Susana Medina. 2008. "Assessing Integration Methodology (AIM): A Handbook for Measuring and Assessing the Integration of Family Planning and Other Reproductive Health Services." Washington, DC: Population Council. 


\section{Authors}

M. Estela Rivero-Fuentes, Saumya RamaRao, Ricardo Estrada, Charlotte E. Warren, Saiqa Mullick, Ian Askew, Harriet Birungi, John Townsend, and Susana Medina 


\section{Assessing Integration Methodology}

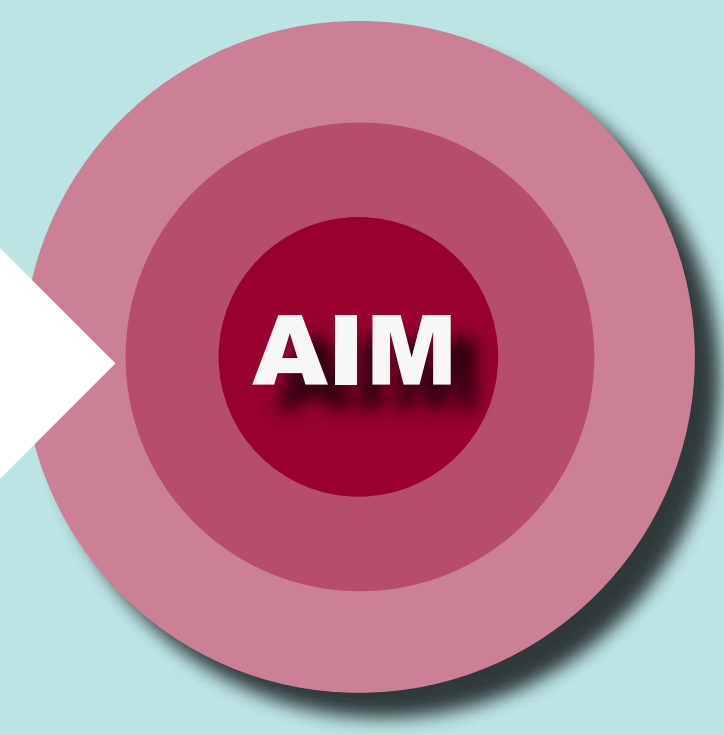

A Handbook for Measuring and Assessing the Integration of Family Planning and Other Reproductive Health Services 



\title{
Assessing Integration Methodology (AIM)
}

\author{
A Handbook for Measuring and Assessing the Integration \\ of Family Planning and Other Reproductive Health Services
}

\author{
Frontiers in Reproductive Health \\ Population Council \\ M. Estela Rivero-Fuentes \\ Saumya Ramarao \\ Ricardo Estrada \\ Charlotte Warren \\ Saiqa Mullick \\ Harriet Birungi \\ Ian Askew \\ John Townsend \\ Susana Medina
}

2008

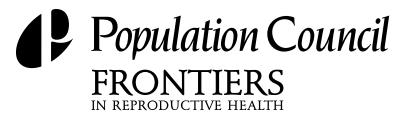


The Population Council is an international, nonprofit, nongovernmental institution that seeks to improve the well-being and reproductive health of current and future generations around the world and to help achieve a humane, equitable, and sustainable balance between people and resources. The Council conducts biomedical, social science, and public health research and helps build research capacities in developing countries. Established in 1952, the Council is governed by an international board of trustees. Its New York headquarters supports a global network of regional and country offices.

The Frontiers in Reproductive Health Program (FRONTIERS) applies systematic research techniques to improve delivery of family planning and reproductive health services and influence related policies. FRONTIERS is funded by the United States Agency for International Development (USAID) and led by the Population Council in collaboration with Family Health International.

This publication is made possible by the generous support of the American people through the United States Agency for International Development (USAID) under the terms of Cooperative Agreement No. HRN-A-00-98-00012-00. The contents are the responsibility of the FRONTIERS Program and do not necessarily reflect the views of USAID or the United States Government.

This publication may be reproduced in whole or in part without permission of Population Council provided full source citation is given and the reproduction is not for commercial purposes.

Suggested citation: Rivero-Fuentes, Estela, et al. "Assessing integration methodology (AIM): A handbook for measuring and assessing the integration of family planning and other reproductive health services," FRONTIERS Manual. Washington, DC: Population Council.

Frontiers in Reproductive Health Program (FRONTIERS)

Population Council

4301 Connecticut Avenue, NW, Suite 280

Washington, DC 20008

Telephone: (202) 237-9400

Facsimile: (202) 237-8410

E-mail: frontiers@popcouncil.org

www.popcouncil.org/frontiers

(C) 2008 The Population Council, Inc. 


\section{Contents}

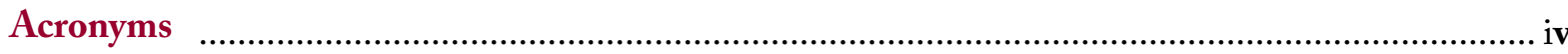

Background

Section 1: Assessing Integration Methodology: Why, what and how? ..............................................1

Section 2: Data collection instruments for the integration of family planning and antenatal care services

Section 3: Data collection instruments for the integration of family planning and postnatal care services

Section 4: Data collection instruments for family planning in postabortion care services

Section 5: Data collection instruments for the integration of family planning and HIV and STI prevention and detection 


\begin{tabular}{|c|c|}
\hline AIM & Assessing Integration Methodology \\
\hline ALVA & Consultoria y Asesoria \\
\hline ANC & Antenatal Care \\
\hline CDPHC & Center for Development in Primary Health Care \\
\hline CERA & Centre d'Evaluation et de Recherche Apliquee \\
\hline CIOMS & Council for International Organizations of Medical Sciences \\
\hline C\&T & Counseling and Testing \\
\hline DHS & Demographic and Health Surveys \\
\hline $\mathrm{ERC}$ & Ethical Review Committee \\
\hline ESIC & Employees' State Insurance Corporation \\
\hline FANC & Focused Antenatal Care \\
\hline FASQ & Facility Audit of Service Quality \\
\hline $\mathrm{FP}$ & Family Planning \\
\hline FGD & Focus Group Decisions \\
\hline FRONTIERS & Frontiers in Reproductive Health Program \\
\hline $\mathrm{HFC}$ & Health Facility Census \\
\hline HIV & Human Immunodeficiency Virus \\
\hline $\mathrm{ICU}$ & Integral Care Units \\
\hline IRB & Institutional Review Board \\
\hline JICA & Japan International Cooperation Agency \\
\hline $\mathrm{M} \& \mathrm{E}$ & Monitoring and Evaluation \\
\hline $\mathrm{MCH}$ & Maternal and Child Health \\
\hline MEASURE & Monitoring and Evaluation to Assess and Use Results \\
\hline MODE & Taylor Nelson Sofres Mode Pvt. Ltd. \\
\hline $\mathrm{MOH}$ & Ministry of Health \\
\hline MSH & Management Sciences for Health \\
\hline $\mathrm{PAC}$ & Postabortion Care \\
\hline $\mathrm{PNC}$ & Postnatal Care \\
\hline PMTCT & Prevention of Mother to Child Transmission \\
\hline PSAM & Prevention Service Availability Mapping \\
\hline RA & Rapid Assessment Tool for Sexual and Reproductive Health and HIV Linkages \\
\hline SA & Situation Analysis \\
\hline SPA & Service Provision Assessment \\
\hline $\mathrm{SRH}$ & Sexual and Reproductive Health \\
\hline STI & Sexually Transmitted Infections \\
\hline SyS & Systematic Screening \\
\hline VCT & Voluntary Counseling and Testing \\
\hline WHO & World Health Organization \\
\hline
\end{tabular}




\section{The origins and purpose of this handbook}

Several international statements over the past two decades have endorsed the integration of family planning (FP) services with other reproductive health services as a means of expanding availability and access for potential users. Initially, the focus was on integrating FP with maternal and child health $(\mathrm{MCH})$ services; indeed, in virtually all African countries, FP services were initially introduced through integrating their provision into existing $\mathrm{MCH}$ service programs. Although FP services were introduced in Africa through organizing their provision within existing $\mathrm{MCH}$ programs, rather than creating separate programs as had largely been the case in Asia, they still tended to be provided separately from, rather than integrated with, the antenatal, delivery, postnatal, and child health services offered by these programs.

More recently, there has been tremendous interest in exploring ways of integrating the provision of FP information and services with other relevant services. For example, counseling during antenatal care (ANC) on the importance of using FP after delivery for spacing births and the subsequent provision of contraceptive methods in the postpartum period during postnatal and child health consultations are widely recommended as 'postpartum FP' services (Vernon 2008). Efforts to incorporate FP counseling as an integral component of focused antenatal care (FANC) (WHO 2002; Birungi et al. 2006; Birungi and Onyango-Ouma 2006) and to develop integrated postnatal-FP service packages during the series of consultations during the 12-month postpartum period, all demonstrate the increasing interest in integrating FP with MCH services (Mwangi, Koskei, and Blanchard 2008). For more than a decade, the value of offering FP services to women receiving postabortion services has been recognized and endorsed, with FP being seen as one of the critical components of any postabortion care (PAC) service (Postabortion Care Consortium 2002). Since the advent of the AIDS pandemic, especially in Africa, considerable attention is being paid to both integrating FP information and services into services for the prevention, management, and treatment of HIV/AIDS and other sexually transmitted infections (STIs), as well as integrating these services with $\mathrm{FP}$ services (WHO, UNFPA, UNAIDS, and IPPF 2005).

The World Health Organization (WHO) defines integrated service delivery as:

"The management and delivery of health services so that clients receive a continuum of preventive and curative services according to their needs over time and across different levels of the health system." (WHO 2008)

Many rationales underlie the move toward integrating FP with other services. First among these is that combining the provision of one or more services provides a number of benefits to both the client and the program. Moreover, there is the expectation (although evidence is still scarce) that the costs to the health system of configuring two or more services to be provided either jointly at the same time and by the same provider or through referral will be less than providing these services independently (Das et al. 2007). These benefits include: (1) meeting multiple reproductive health needs of a client simultaneously, (2) reducing the stigma associated with providing a service independently, (3) combining several services needed for a multifaceted health condition, and (4) achieving cost efficiencies through sharing staff skills, infrastructure, and equipment. Experience indicates, however, that creating service configurations for integrated services is usually not straightforward; can place a strain on the underlying logistics, training, supervisory, and management systems, especially if the services are provided through different programs (as is the 
case with sexual and reproductive health [SRH] and HIV/AIDS services); and may overstretch service providers with limited skills and support.

However, there is still remarkably little empirical evidence available about integration of services to guide policy makers, program managers, those providing technical assistance, and those responsible for financing health care. The following questions are critical, but the answers remain largely unknown, or are uncertain in a particular country or program context:

- Which service combinations are feasible?

- Which services are acceptable to clients and providers?

- Which services can effectively increase access to one or both services without compromising the quality or safety of their delivery?

- Does their joint provision lead to a synergistic impact on both the individual client's health status and that of the population served?

In part, this knowledge gap exists because there has been little attention paid to assessment methodologies to generate such information. Over time, a number of methodologies for undertaking what are known as health facility assessments (HFAs) of service delivery have been developed and field-tested (Measure/Evaluation 2006; International Health Facility Assessment Network 2008), but none of these focus specifically on measurement of the integration of services.

This handbook presents a methodology that seeks to address this gap. Termed the Assessing Integration Methodology, or AIM, it has been developed from experience gained by the Population Council in undertaking assessments of various combinations of integrated services in many developing countries, most of which was undertaken through the USAID-funded Frontiers in
Reproductive Health Program (FRONTIERS). This methodology derives from the Situation Analysis (SA), a methodology originally devised by the Population Council in the 1990s through its USAID-funded Africa OR/TA Project, to better understand the range of programmatic factors that influence the quality of care received by a client during facility-based FP services (Miller et al. 1997; Miller et al. 1998).

Since the SA methodology was first developed and used in Kenya in 1990, the means by which FP and other SRH services are delivered have increased and changed substantially, most notably through the integration of FP with other services. Offering services in a combined fashion requires appropriate methodologies for determining the feasibility of various combinations, assessing and monitoring the quality of service received, and evaluating their effect on utilization. Responding to this need, FRONTIERS has adapted and revised the SA methodology to create and use AIM to help health programs in many countries to address the questions concerning integration posed above.

Over the past decade, FRONTIERS has implemented more than 15 projects in a dozen countries that have assessed the feasibility, acceptability, and effectiveness of integrating FP services with maternal and child health, postabortion, and HIV/STI prevention. The purpose of this handbook is to serve as a reference for organizations and individuals that would benefit from methodological guidance when describing, measuring, or assessing

\section{Map of FRONTIERS country projects using AIM}

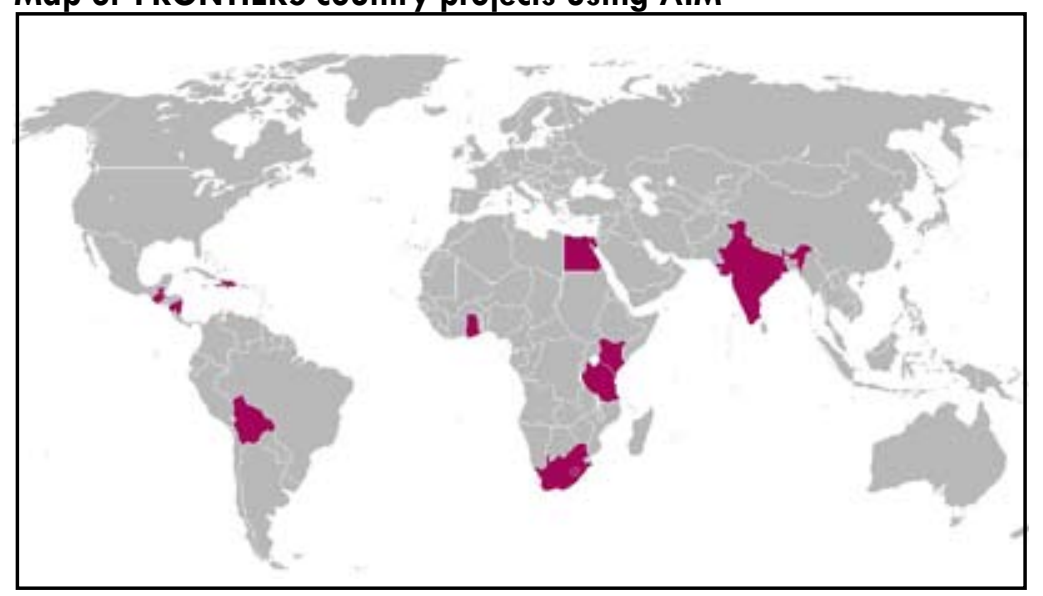


integrated services. The handbook (a) explains the basic principles of conducting studies using AIM,

(b) provides tips for the data collection, and

(c) makes available data collection instruments

that have been validated in projects throughout the developing world. The map on the previous page highlights those countries in which

FRONTIERS carried out projects utilizing the AIM strategy. Additionally, a detailed list of these projects can be found in Appendix 3.

\section{How to use the materials in this handbook}

The focus of this handbook is on the AIM and the instruments that can be used to collect data at health facilities offering, or considering offering, integrated services. Data analysis will depend on the specific objectives of each study and so will not be reviewed here; most HFAs such as AIM use primarily univariate or bivariate descriptive statistics, so advanced statistical skills are usually not required. Examples of the types of analyses that can be undertaken with AIM data can be found in the reports from the completed studies (all available on the Population Council's website). Once the context and objectives of the study have been specified, the data collection instruments provided here can be adapted and adjusted to ensure that they cover only the issues of interest so that unnecessary data are not collected.

The handbook is organized in five sections. The first section describes the overall methodology in terms of:

- Uses for AIM

- Components of an AIM study

- Data collection instruments

- Conducting an AIM study

- Limitations of AIM

- Comparison of AIM with other HFA methodologies
Sections 2 to 5 present generic data collection instruments for implementing AIM studies that address the integration of $\mathrm{FP}$ with four services: ANC, postnatal care (PNC), PAC, and STI/HIV services. Each section includes:

- A facility inventory of services, infrastructure, equipment, and supplies

- An observation guide for recording provider-client interactions

- A standardized questionnaire for exit interviews with clients

- A questionnaire for interviews with providers

The questions included here have been tested and validated in more than one setting. The instruments are intended to be comprehensive and therefore include some topics that will not be relevant for every context or study; to facilitate adaptation of the instruments, items that are fundamental for all AIM studies are distinguished from those that are specific for a particular combination of services. 


\section{Using this handbook}

The Assessing Integration Methodology (AIM) can be used to describe, measure, and assess many aspects of integrated services:

- Type of integration of services

- Readiness of health facilities and staff to provide integrated services to clients

- Number and type of services accepted by clients

- Quality of care received by clients for each individual service

- Costs to the program and service fees

- Acceptability of integrated services to providers and client satisfaction with integrated services

As an example, consider using AIM to help a sexual and reproductive health (SRH) program decide how to better integrate family planning (FP) into existing counseling and evacuation services to create a package of postabortion care (PAC). Using AIM, program managers could learn which FP services and which postabortion services are currently available at the health facilities of interest, whether there is any existing integration among the services, and which configurations could be considered to better enable a PAC client to receive all relevant services. For example, should FP services be provided in the same place and by the same staff that provide the evacuation counseling and service, or should they be provided through referral of clients to the unit in the facility that delivers FP services? What is the best timing during the visit to discuss and provide FP? AIM can provide valuable information on whether facilities have the necessary staff, infrastructure, equipment, supplies, and commodities and are organized appropriately for FP to be integrated with postabortion evacuation.
Having used AIM to design one or more service configurations, it could then be used again after introducing this configuration(s) on a pilot basis to assess the feasibility of each configuration, its acceptability to staff and clients, and whether the proportion of clients receiving and using FP services increased as a result of offering integrated services compared with when the services were not integrated. Once the final service configuration has been decided on and put into place, elements of AIM can be used to monitor integrated services. Appendix 1 shows examples of how AIM has been used to guide and evaluate the integration of $\mathrm{FP}$ with maternal and child health (MCH) and testing and treatment services for HIV and sexually transmitted diseases (STIs).

The findings from assessments using AIM most often inform decisions about the delivery of integrated services at the program and systems level, and can also guide the development of health sector policies. The data are collected, however, through visits to a sample or universe of health facilities, in order to understand what is happening and what is feasible at the point of contact with the client. Other methodologies do exist that collect information from program and policy levels in the health system ${ }^{1}$ to better understand the systems, policy, and management implications of integrating services, and indeed some studies that use AIM also include data collection instruments to address such factors (e.g., the assessments of integrating FP into focused antenatal care (FANC) in Ghana [Birungi et al. 2006] and Kenya [Birungi and Onyango-Ouma 2006]).

\footnotetext{
${ }^{1}$ For example, the WHO/AFRO region and the United Nations Population Fund (UNFPA) are developing a rapid assessment tool for services integration that includes both a small sample of facilities and interviews with policymakers and program managers (WHO/AFRO and UNFPA Regional Committee 2008). UNFPA, IPPF, WHO, and UNAIDS are in the process of developing a generic tool for integrating $S R H$ and HIV/AIDS.
} 
AIM has been used to assess services in facilities at primary through tertiary levels and in different sectors (public, private, and non-governmental organizations [NGOs]). Studies using AIM can include all facilities in a district or region, or they can be used in a smaller sample of facilities representative of a particular administrative/ geographic area or program. While the maximum number of facilities included in any study is usually determined by budgetary considerations, the minimum number and type of facilities included in a sample should be guided by the study's purpose.

\section{When a program needs to diagnose the}

feasibility of being able to provide integrated services, the number of facilities to include will be determined by the types of facilities in which the integration of services is being considered. For example, if integration is being considered only at the primary level, then only primarylevel clinics need to be included. If integration is being considered in both public sector and NGO programs, then facilities from both programs (and at all relevant levels) need to be included. Although a census of all facilities may be considered when the number of facilities of interest is small-for instance, when studying tertiary-level facilities or those in a small NGO - a representative sample of facilities is usually sufficient and is recommended in order to conserve resources and ensure a rapid diagnostic assessment.

For diagnostic purposes, the sample should represent the variability of facilities in terms of those factors that may affect the delivery and quality of service provision. Generally speaking, this means ensuring that the sample reflects the different types of facility that may offer the integrated services (e.g., general hospital, specialized hospital, health center, and dispensary), the administrative/geographic locations where they would be introduced (e.g., region, province, and urban/rural), and type of sector (e.g., public, private, and NGO). In addition, the number of facilities in each group should be sufficient to be representative of that group and to enable comparisons to be made. Simple random sampling, cluster random sampling, or stratified random sampling also can be used when selecting the facilities to include.

When a program is seeking to pilot-test

the effectiveness of one or more models for configuring services, it is preferable to use an experimental or quasi-experimental design (Fisher et al. 1998; Fisher and Foreit 2002). With such a design, one or more new configurations of services can be introduced into a small group of facilities (approximately six to eight) to form the experimental group. The nature and quality of services provided in these facilities can then be compared with provision of the same services in a group of facilities with similar characteristics that are delivering the services in the existing configuration. The experimental and comparison groups of facilities can be created by either:

- Selecting the experimental group first (either randomly or according to certain criteria, such as location, type, and program affiliation) and then selecting a group of equivalent facilities that have been "matched" for similar characteristics; or

- Randomly selecting 12 to 16 facilities and then randomly assigning 6 to 8 to the experimental group and 6 to 8 to the control group.

AIM can then be used at each facility to measure the key process and outcome variables, which can then be compared statistically to determine whether there are significant differences between offering the services individually or jointly.

The number of consultations that should be observed and the number of clients that should be interviewed can vary depending on the objectives of the study and the resources available. The number of observations and client exit interviews should be sufficient to generate information that is representative of the service(s) being assessed and may need to be determined based on the magnitude of change in specific outcome variables that needs to be detected.

In most AIM studies, the intention is to assess the services offered by a facility rather than by individual providers. The number of observations 
and interviews, therefore, is usually determined for a facility, regardless of which provider is delivering the service, on the assumption that the AIM is being used to describe the services available and received by clients on the day of the research team's visit, which, having been randomly selected, is assumed to be representative of a typical day. In general, most AIM studies have sought to observe and interview at least five or six clients receiving a particular service. If there is interest in comparing the nature and quality of service provided to clients with different characteristics, then it will be necessary to observe and interview five to six clients with each characteristic, for example, new and revisiting FP clients or younger and older clients. This sample size is based on Lot Quality Assurance Sampling ${ }^{2}$, a sampling method that enables performance to be assessed with small sample sizes.

\section{Components of the assessment}

The AIM collects data from facilities through a visit to the facility by a research team, usually comprising two persons. During their visit, the team stays in each facility for a minimum of one full day and conducts the following activities:

- Carries out an inventory of services, equipment, and supplies available

- Collects all service statistics available for the past 12 months

- Interviews service providers delivering the services of interest

- Observes the interaction between service providers and clients

- Interviews clients before they leave the facility

These five datasets, when used jointly, will provide the information needed to address the types of issues described above for which the AIM has been designed. Descriptions of the four instruments used to collect them (abstraction of service statistics is included in the facility inventory) are given below. Although one day

\footnotetext{
2 For an overview, see http://www.cpc.unc.edu/measure/ publications $/ \mathrm{html} / \mathrm{ms}-00-08$-tool09.html.
}

is usually sufficient to complete the inventory and provider interviews, for studies in which large numbers of clients need to be observed and interviewed, and/or the facilities have low client loads, it may be necessary for some members of the team to stay for five or more days at each clinic.

Some studies using AIM have also incorporated other data collection methods such as: (1) document reviews to identify national policies and standards; (2) interviews with key informants not present at the facility, such as program managers and policymakers, staff in technical assistance, and donor agencies (Birungi et al. 2006); (3) in-depth interviews and focus group discussions (FGDs) with service users and nonusers (Rivero-Fuentes et al. 2008); (4) ethnographic descriptions of the context where services are provided (Quiterio et al. 2008); and (5) client flow analyses (Youssef et al. 2007). Including such methods can provide important additional insights into how services are perceived and delivered and how programs function; their use will, however, increase the resources and time needed for a study. Table 1 , on the following page, lists some of the studies in which these optional data collection methods have been used.

\section{Data collection instruments}

AIM measures the availability of services and the readiness of facilities to offer them. It also describes the actual services that clients receive and measures their quality. Four data collection instruments are used to collect this information:

\section{A) Inventory for facilities available and services provided at the facility. The main purpose of the inventory is to assess the readiness of a facility to provide services, both individually and together. The inventory instrument comprises items that describe:}

- Availability of particular services

- Their organization within the facility

- Management, supervision, and recordkeeping procedures followed 
- Equipment, supplies, materials, and commodities available and in working order

- Service statistics for the preceding 12 months

The inventory is usually completed through two means: direct observation of the availability of equipment, supplies, and infrastructure and a semi-structured interview with the facility manager, or someone knowledgeable about its functioning and organization, to collect information on items such as facilitylevel procedures and staffing availability. One inventory is completed per facility.

B) Observation guide. This instrument allows a nonparticipant observer to record what happens during the consultation between the client and provider. After obtaining informed consent from both the provider and client, information is recorded on an itemized checklist by the observer, who sits silently in the area where the service(s) is being provided. Observers should have clinical training in service delivery, as well as be thoroughly trained in non-participant observation, so they can identify the procedures and examinations that occur during the consultation and the information exchanged between provider and client. The observation guide contains a listing of all of the key items that should be covered when counseling and providing a client with the service of interest, and the observer is expected to record (usually with a tick) when an item is covered. The observer needs to be very familiar with the structure of the observation guide because most client-provider interactions will not follow the same path. The observer should also be prepared to make notes in the margin for items covered in the consultation that are not included in the observation guide.

For some services, and especially services that are integrated, a client may be required to interact with more than one provider, or with the same provider at different places within the clinic. In these situations, two approaches have been used: (1) the observer accompanies the client as she progresses through the clinic (preferable, but feasible only in facilities or for services with low client loads or for which a small number
Table 1.

Examples of additional data collection methods used with AIM

\begin{tabular}{|l|l|l|}
\hline Mechanism & $\begin{array}{l}\text { Type of information } \\
\text { collected }\end{array}$ & Example \\
\hline $\begin{array}{l}\text { Interviews } \\
\text { with key } \\
\text { informants }\end{array}$ & $\begin{array}{l}\text { Perspectives of MOH } \\
\text { directors and cooperation } \\
\text { agencies on the functioning } \\
\text { of programs }\end{array}$ & $\begin{array}{l}\text { Nicaragua 2008, } \\
\text { Integration of } \\
\text { family planning } \\
\text { and postpartum } \\
\text { services }\end{array}$ \\
\hline $\begin{array}{l}\text { Focus group } \\
\text { discussions } \\
\text { with the } \\
\text { community }\end{array}$ & $\begin{array}{l}\text { Collective perceptions of } \\
\text { a group of potential users } \\
\text { about the accessibility and } \\
\text { quality of services }\end{array}$ & $\begin{array}{l}\text { Senegal 2007, } \\
\text { Postabortion } \\
\text { services }\end{array}$ \\
\hline $\begin{array}{l}\text { Focus group } \\
\text { discussions } \\
\text { with users }\end{array}$ & $\begin{array}{l}\text { Commonalities in users } \\
\text { experiences and needs }\end{array}$ & $\begin{array}{l}\text { Nicaragua 2008, } \\
\text { Integration of } \\
\text { family planning } \\
\text { and prevention } \\
\text { of mother to child } \\
\text { transmission of } \\
\text { HIV }\end{array}$ \\
\hline $\begin{array}{l}\text { In-depth } \\
\text { interviews } \\
\text { with selected } \\
\text { clients }\end{array}$ & $\begin{array}{l}\text { In-depth understanding } \\
\text { of clients experience } \\
\text { and satisfaction with the } \\
\text { services }\end{array}$ & $\begin{array}{l}\text { Dominican } \\
\text { Republic 2008, } \\
\text { Integration of } \\
\text { family planning } \\
\text { and postpartum } \\
\text { services }\end{array}$ \\
\hline $\begin{array}{l}\text { Ethnographic } \\
\text { observation }\end{array}$ & $\begin{array}{l}\text { Description of the } \\
\text { environment where services } \\
\text { are provided and of the } \\
\text { way in which clients are } \\
\text { treated }\end{array}$ & $\begin{array}{l}\text { Dominican } \\
\text { Republic 2008, } \\
\text { Integration of } \\
\text { family planning } \\
\text { and postabortion } \\
\text { care services }\end{array}$ \\
\hline $\begin{array}{l}\text { Measurement of the time } \\
\text { clients spend in each station } \\
\text { during their visit to the } \\
\text { facility }\end{array}$ & $\begin{array}{l}\text { Nairobi, Kenya } \\
\text { 2001, Syphilis } \\
\text { screening program } \\
\text { in antenatal clinics }\end{array}$ \\
\hline
\end{tabular}

of clients are being observed); or (2) separate observers are stationed at each step of the service and observe and record that step for each client on their individual checklist (can be used when many clients are being observed and each step of the service is fairly well-defined).

The observation guide is primarily used to assess the quality of care provided during the consultation, in terms of whether the provider follows expected norms and procedures for delivering a service (i.e., provider compliance), the information exchanged and the decisions reached concerning the client's use (or nonuse) of the service, and any follow-up actions to be taken. Consequently, the items included are usually derived from national and international service delivery guidelines for each service being measured, and therefore construction of 
this tool usually requires extensive consultation with relevant experts. This approach also allows quantitative summary scores to be calculated for each consultation by aggregating the number of items correctly covered when providing a service(s). These scores can then be aggregated to estimate a mean score for the provider or facility, and can be used to make comparisons with other providers/facilities and/or against some agreedupon standard or norm. For examples, see the scoring systems developed for HIV counseling and testing $(\mathrm{C} \& \mathrm{~T})$ integrated with FP (Liambila et al. 2008) and for FP integrated with postnatal care (PNC) (Mwangi et al. 2008) in Kenya.

\section{C) Questionnaire for clients' exit interviews.}

After observing the client-provider interaction, clients are asked for their informed consent to have a short exit interview before they leave the facility. These interviews collect information about the clients' perceptions of the service(s) just received and gather some information about their personal desires, intentions, and attitudes concerning $\mathrm{FP}$ and other issues around reproductive health that are relevant to the services obtained. This information complements that gathered through observation on the quality of care received and can be used to contextualize how and why the client will use the service received.

At a minimum, an AIM study should interview all clients whose consultation has been observed. If resources permit, it may be possible to interview all clients receiving that service on the day(s) of the research team's visit, which would increase the validity of the findings. However, in cases where a large number of clients are receiving services, a subsample of the total will need to be drawn. For example, when researchers were conducting an AIM study on the integration of antenatal care (ANC) and FP in two of the National Maternities in the Dominican Republic, the team interviewed every fourth antenatal client (Quiterio et al. 2008) to generate a systematic random sample.

\section{D) Questionnaire for providers' interviews.}

These structured instruments are used to gather information on the training, knowledge, perceptions, and practices of providers. The information from these interviews can be used to determine the levels of knowledge and attitudes of providers toward the services to be integrated and their experience in their provision. From diagnostic studies, training can be developed to build the capacity of staff to implement integrated services, and find out the acceptability of integrated services by providers, most of whom are probably more used to providing services individually. One interview guide is completed for all providers at a facility who provide the services of interest and are present on the day of the visit (for example, a study on the integration of $\mathrm{FP}$ and $\mathrm{PAC}$ should interview all providers delivering the evacuation services and those providing the FP services, if different persons).

\section{Conducting an AIM study}

The design and implementation of an AIM study can be thought of as a series of steps, as follows:

1. The decision to conduct a study and the definition of the objectives

2. The selection of the sample

3. The design of the data collection instruments

4. The data collection process

5. Data entry and cleaning

6. Data analysis and dissemination and utilization of the results

It is highly recommended that program managers and other stakeholders who will use the data are actively involved in as many of these steps as possible. At a minimum, they need to (a) participate in specification of the study objectives and selection of facilities to be included, (b) review and comment on the data collection instruments, (c) interpret the preliminary findings, and (d) develop plans and budgets for using the findings. Box 1 lists some of the key decisions that need to be made when designing a study.

Implementation of studies using AIM is exactly the same as that used for SA studies and other HFAs. Guidelines for implementing SA studies published by the Population Council (Miller et 
al. 1997) give detailed descriptions of the key steps and activities that should be followed when conducting such a study; in brief, a typical AIM or HFA study will include the activities outlined in Appendix 2.

AIM collects information from human subjects, and so although the intention of carrying out the research is to benefit future service users, all interviews and observations have some potential risk for causing harm to the study participants. To minimize these risks, all studies should comply with local and international laws and regulations governing the review of research proposals. ${ }^{3}$ Depending on the context and funding mechanism, a study proposal will have to be submitted for review and approval by an Institutional Review Board (IRB) and/or an Ethical Review Committee (ERC), each of which may have its own guidelines and requirements. To meet these requirements, all health facility assessments (HFAs) must be designed and implemented to follow the three general principles governing all research involving human subjects (CIOMS 2002): (1) respect for personal autonomy and protection of vulnerable persons with impaired or diminished autonomy; (2) beneficence, that is, the obligation to maximize benefits and to minimize harms; and (3) justice, which requires the equitable distribution of the burdens and the benefits of participation in research.

These review committees should be independent of the research team, and their approval must be obtained before undertaking the research. Studies that are sponsored by foreign organizations should submit the research protocol for review in the country of the sponsoring organization as well as the host country. This process can often take up to six months or more, and therefore needs to be scheduled into the overall study plan.

All providers and clients need to give their informed consent before information can be collected, indicating that (a) they understand the nature of the study and any risks and benefits

\footnotetext{
${ }^{3}$ A useful series of papers discussing a variety of ethical issues around research on reproductive health services can be found in a special edition of Studies in Family Planning (Population Council 2007).
}

Box 1.

Important decisions when designing a study using AIM

1) What are the specific objectives of the study?

2) Of all the different methodologies available, is AIM the most appropriate for achieving these objectives?

3) Which type of facilities will be assessed?

4) Will the study include facilities that are already implementing the services to be integrated, or will it include facilities that do not yet offer one or more of these services?

5) How many facilities should be included in the study? How are these to be selected?

6) How many observations of client-provider interactions are needed for each service and for each facility?

7) Which instruments will be used?

8) What topics will be covered in the instruments?

9) How many research teams with what members will be needed to visit each facility?

10) What kind of training or professional background is needed from the team?

11) How many days should a team stay at each facility?

12) Where are clients going to be interviewed?

13) Are all clients going to be interviewed or only those observed receiving a service?

14) What indicators will be presented in the report?

15) How will stakeholders be engaged with and participate in the study design and implementation?

16) Are the data being collected clearly relevant for decisions to be made concerning the introduction or strengthening of integrated services?

associated with their participation, (b) they can refuse to answer any questions or stop the interview or observation at any time, and (c) the information collected will be confidential. Clients must be informed that they can receive all services whether or not they participate, and providers must understand that the results will not be communicated to their supervisors in a way that could identify them individually. This understanding of informed consent is important because, during some AIM studies, requests have been made by supervisors about the performance of individual providers. Consent should not be obtained when the client is under duress, in pain, medicated with consciousness-altering drugs, or in need of acute care; particular care is needed when collecting data from women receiving PAC services, who have delivered recently, or who may have recently been diagnosed with a serious condition, such as HIV. Also, potential 
participants should be able to differentiate clinic staff from researchers collecting assessment data so they do not agree to participate in the study thinking that not participating could affect the quality of their care.

Most IRB/ERCs require that a written informed consent form is read and signed by the participant before the interview or observation takes place. To maintain the confidentiality of subjects, these consent forms should be kept separately from the instruments in a secure and private place.

Some studies may have sufficient resources to reimburse subjects for time spent while answering the questions in the interview schedules. These payments should only be symbolic and small enough so they do not coerce participation in the study.

Providers who are being observed can become nervous, which potentially could put clients at some risk. However, experience suggests that providers actually tend to perform to the best of their ability when being observed, and so the more important issue is that analysis of the data takes this possibility into account.

For some IRBs, informed consent from providers is not considered necessary if the research activity has been approved by their supervisors and organization. In these situations, informed consent is only necessary if information of a personal nature (such as questions about their attitudes, beliefs, personal practices, and socioeconomic status), rather than related to their professional work, is being collected. The data collection instruments used in AIM studies generally do not collect this information, but it is important to review this possibility during their adaptation.

Some AIM studies require that a cohort of clients is followed over time and reinterviewed (see, for example, the study of postnatal FP in Kenya [Mwangi et al.2008]) to assess whether new service configurations affect the mediumterm behavior of clients. Clients must be asked, at the beginning of the exit interview, whether they are willing to be recruited into the cohort, if they are willing to have their names and addresses recorded, and if they are willing to be reinterviewed at a later point in time. Because this information identifies a client, the name and address must be removed from the rest of the questionnaire and stored separately; the only identifier on the questionnaire should be a code number. At this stage, study subjects must be made aware that follow-up contacts may take place in their homes or another location where a spouse or other family member may learn that the interviewee has obtained a clinical service they wanted to keep secret (e.g., FP or treatment for an STI). If the client does not wish to be in the study for this or any other reason, the researcher must honor their decision.

AIM studies are designed to measure service quality and identify improvements that can be addressed by a program later. Occasionally, however, observers may witness a gross violation of acceptable provider behavior that puts the client at risk of morbidity (for example, if a provider conducts a pelvic examination without disinfecting the instruments first). In such instances, the observer has the responsibility to intervene to protect the client from potential harm, even if their intervention influences the research and leads to the observation being excluded from the study. A list of such potential situations that might call for some form of intervention should be developed in collaboration with project managers and relevant local authorities and reviewed during training. For this reason, it is also strongly recommended that all observers of client-provider interactions in AIM studies be well-qualified medically and sufficiently competent to detect such problems correctly. Such cases are rare and must be carefully documented and reported when they occur.

\section{Limitations}

As with all research methodologies, AIM does have certain limitations. AIM studies can provide a detailed and systematically organized description of the existing situation at facilities, but it may not be able to pinpoint the precise 
cause of any problems detected. For example, an AIM study may detect that there are frequent contraceptive stock-outs in most facilities, but it cannot distinguish whether these are due to inappropriate mechanisms for ordering resupplies by the facility management or to a general shortage of supply in the country.

AIM studies generate important but limited information on provider competence and skills. Interviews with providers can describe their training and their knowledge of specific topics, and observation of client-provider interactions records their actual performance during interactions with a small number of clients. However, unless there are deliberate efforts to measure the provision of certain services, or combinations of services, AIM studies cannot describe how providers would perform for activities or situations that are not observed. For example, an AIM study may indicate, from provider interviews, that nurses have been trained in delivering postnatal IUD services, but if no postnatal clients choose to use this method on the day(s) of the research team's visit to a facility then, the nurses' competence in doing so cannot be measured.

AIM studies may provide overly optimistic estimates of the typical quality of care provided. Health providers may make an extra effort to give their highest quality of service on the days that the research team visits the facility. This bias decreases if the research team stays in the facility for several days because their presence becomes familiar. Interpreting the findings should always take into account, therefore, that the measures of service quality are likely to be better than typical, and therefore, any inappropriate actions observed should be considered indicative of a possible problem with service delivery and acted upon accordingly.

AIM studies cannot measure the impact of the service received on the client's reproductive health behaviors unless a panel or cohort design is used to follow clients for a period of time after receiving the service. Given that their behavior after receiving the service may also be influenced by other factors besides the service itself, it is important to ensure that follow-up interviews collect information about a range of possible determinants of their behavior, in addition to utilization of the service(s) being assessed.

AIM studies cannot be used to estimate access to health services or the health needs of the general population because they are facility-based. Any information collected about access and the extent to which clients have needs and preferences for certain services can be used only to describe the population that visits the health facilities.

\section{Comparison with other health facility assessment methodologies}

Several methodologies exist for collecting facility-based information for assessing the readiness of facilities and systems to offer services and to assess the quality of care provided. This section presents a brief description of other methodologies, describing their advantages and limitations in comparison with AIM; ${ }^{4}$ Table 2 provides a summary.

Analysis of service statistics. Service statistics are an important resource for monitoring the performance of programs because they can describe trends over time; compare facilities, districts, and sectors; and may also be able to describe some basic characteristics of the clients served. Monitoring delivery of integrated services, however, requires the collection of service statistics that may be recorded in different reports, depending on how the services are organized-this is especially the case when services are provided separately. For example, to monitor whether FP services are being offered within PAC, it may be necessary to collect data from the records of the in-patient ward where the evacuation took place and from the $\mathrm{MCH} /$ FP unit where contraception was discussed and provided. One of the challenges facing the development of integrated services has been

\footnotetext{
4 A detailed comparison of some of these methodologies can be found in Measure/Evaluation (2006). Selected descriptions in the following text have been adapted from http://www.cpc.unc.edu/measure/tools/monitoringevaluation-systems/profiles-of-hfa-methods.
} 
Table 2.

Comparison of facility-based methodologies for monitoring and evaluation of the integration of family planning and other services

\begin{tabular}{|c|c|c|c|c|c|c|c|}
\hline \multirow[b]{2}{*}{ Method } & \multicolumn{7}{|c|}{ Areas measured } \\
\hline & $\begin{array}{l}\text { Quality } \\
\text { of Care }\end{array}$ & $\begin{array}{l}\text { Readiness } \\
\text { to provide } \\
\text { services }\end{array}$ & $\begin{array}{l}\text { Clients' } \\
\text { needs }\end{array}$ & $\begin{array}{l}\text { Services } \\
\text { needed }\end{array}$ & $\begin{array}{l}\text { Integration } \\
\text { model }\end{array}$ & $\begin{array}{l}\text { Time- } \\
\text { trends }\end{array}$ & $\begin{array}{l}\text { Geographical } \\
\text { location of } \\
\text { facilities }\end{array}$ \\
\hline AIM & $\checkmark$ & $\checkmark$ & $\checkmark$ & $\checkmark$ & $\checkmark$ & & \\
\hline $\begin{array}{l}\text { Service } \\
\text { Statistics }\end{array}$ & & & & $\checkmark$ & & $\checkmark$ & \\
\hline Sys & & & $\checkmark$ & $\checkmark$ & & & \\
\hline SPA & $\checkmark$ & $\checkmark$ & $\checkmark$ & & & & $\checkmark$ \\
\hline FASQ & & $\checkmark$ & & & & & $\checkmark$ \\
\hline HFC & & $\checkmark$ & & & & & $\checkmark$ \\
\hline PSAM & & $\checkmark$ & & & & & $\checkmark$ \\
\hline RA & & $\checkmark$ & $\checkmark$ & $\checkmark$ & $\checkmark$ & & \\
\hline
\end{tabular}

the parallel integration of record keeping. For example, when integrating HIV C\&T into FP services in Kenya, adjustments had to be made to the standard FP register to include space for recording the delivery of HIV C\&T during an FP consultation (Liambila et al. 2008). Ensuring that this information is also reported in a facility's overall report on HIV C\&T, and that the service was received during an FP consultation and not as a stand-alone voluntary counseling and testing (VCT) service, can be a challenge.

\section{Service Provision Assessment (SPA).}

Developed by the USAID-funded Monitoring and Evaluation to Assess and Use Results (MEASURE) Program, the SPA can be used to assess the quality of five services (maternal health; child health; FP; STIs; and HIV prevention, care, and support) in the health facilities of a given region or nation. SPA provides information about staff qualifications, adherence to standard practices, resources for providing given services, and other information. The SPA method is useful for stakeholders who are investing in health systems or in the development of health services and who want to objectively observe regional changes over time. A SPA is a nationally representative survey and is commonly conducted in conjunction with a Demographic and Health Survey (DHS). SPAs use data collection methods that are similar to AIM, but they are not designed to assess whether services are integrated.
Facility Audit of Service Quality (FASQ). The FASQ provides low-cost monitoring of facilitybased reproductive and child-health services at every government and private facility in a given region. Information provided by an FASQ includes the range of a health facility's operating hours, its facility infrastructure and readiness to provide quality care, and digital maps of its available services. Local staff can implement a FASQ with minimal or no technical assistance. The FASQ is specifically designed to be useful in the context of decentralization and projectlevel monitoring and evaluation (M\&E); it is recommended when projects or local officials need to quickly and inexpensively monitor health-facility service quality and availability.

Health Facility Census (HFC). The HFC collects detailed information about the physical assets of all the public and semi-public health facilities in a region or nation. The Japan International Cooperation Agency (JICA) designed the HFC to identify health facilities that do not meet criteria in providing key health services in the following areas: availability and condition of physical infrastructure, health services, and equipment; the location of health service delivery points; and headcounts of health workers. By identifying facilities that lack these resources or abilities, the HFC provides a baseline assessment for deciding how to invest resources into an area. 
WHO Health Facility Census (WHO-HFC)
and Prevention Service Availability Mapping

(PSAM). These two systems are designed to

allow national and district planners to regularly map and monitor health-system information.

The WHO-HFC quantifies, estimates, and maps health services and resources, while PSAM quantifies, estimates, and maps HIV prevention efforts. Both of these approaches are districtowned, facility monitoring systems, and HFC in particular is highly adaptable. Teams under the direction of district planners receive PDAs and GPS equipment as well as training in their use; these teams can then collect data about local health facilities on a regular basis.

\section{Rapid Assessment Tool for Sexual and Reproductive Health and HIV Linkages}

(RA). GNP+ et al. (2008) developed a rapid assessment methodology to gather information on the status of integration of SRH and HIV and AIDS policies, programs, and services. This methodology collects information from decisionmakers and program planners at the central level and from development partners on the status and priorities of service integration. In addition, this methodology undertakes provider and client interviews in a small, representative sample of facilities to gather information about providers' integration practices, services that clients received, and their attitudes toward integrated services.

\section{Systematic Screening (SyS) for determining} and meeting clients' reproductive health needs. This strategy, developed by the Population Council and tested in a variety of contexts, is an intervention to help providers detect and address unmet reproductive health needs of a client in addition to the primary purpose of her/his visit to a facility (Vernon, Foreit, and Ottolenghi 2008). Providers use a brief checklist to identify each client's needs and desires for reproductive health services and then provide them to the client either during the same visit, through an appointment at the same facility, or through referral to another clinic. Although not a methodology to generate information about the level of integration of services, implementation of SyS requires that a facility collects data about clients' needs and acts upon these data to provide improved, integrated services.

\section{Contents of the following sections}

The next sections of this handbook contain examples of the four core data collection instruments for implementation of AIM studies. The instruments are designed to assess the integration of $\mathrm{FP}$ and four other reproductive health services: (1) antenatal, (2) postnatal, (3) postabortion, and (4) HIV and STI prevention and detection. These instruments were developed and tested by the Population Council in different contexts. They are generic and can be easily adapted for use in any country. 


\section{Bibliography}

Birungi, H. and W. Onyango-Ouma. 2006.

"Acceptability and sustainability of the

WHO focused antenatal care package in Kenya,"

FRONTIERS Final Report. Washington, DC:

Population Council.

Birungi, H. et al. 2006. "Acceptability and feasibility of introducing the WHO focused antenatal care package in Ghana," FRONTIERS Final Report. Washington, DC: Population Council.

CIOMS. 2002. International Ethical Guidelines for Biomedical Research Involving Human Subjects. Geneva: Council for International Organizations of Medical Sciences (CIOMS).

Das, R. et al. 2007. "Strengthening financial sustainability through integration of voluntary counseling and testing services with other reproductive health services," FRONTIERS Final Report. Washington, DC: Population Council.

Fisher, A. et al. 1998. Handbook for Family Planning Operations Research Design (2nd edition). New York: Population Council.

Fisher, A. and J. Foreit. 2002. Designing HIVI AIDS Intervention Studies: An Operations Research Handbook. New York: Population Council.

GNP+ et al. 2008. Rapid Assessment Tool for Sexual \& Reproductive Health and HIV Linkages: Generic Guide. Mexico City: IPPF, UNFPA, WHO, UNAIDS, GNP+, ICW and Young Positives.

Hong, R., et al. 2005. "Ghana Trend Analysis for Family Planning Services, 1993, 1996, and 2002,” DHS Trend Reports, No. 1. Calverton, Maryland USA: ORC Macro.

International Health Facility Assessment Network. 2008. "Health facility assessment: Relevant resources/supporting documents and mapping resources: Annotated bibliography," Working Paper WP-08-107, Chapel Hill, NC: Carolina Population Center.
Liambila, W. et al. 2008. "Feasibility, acceptability, effect, and cost of integrating counseling and testing for HIV within family planning services in Kenya," FRONTIERS Final Report. Washington, DC: Population Council

Measure/Evaluation. 2006. "Profiles of Health Facility Assessment Methods," Technical Report tr-06-36. Washington, DC: JSI.

Miller et al. 1997. The Situation Analysis Approach to Assessing Family Planning and Reproductive Health Services: A Handbook. New York: Population Council.

Miller et al. (eds.) 1998. Clinic-Based Family Planning and Reproductive Health Services in Africa: Findings from Situation Analysis Studies. New York: Population Council.

Mwangi, A. et al. 2008. "Strengthening postnatal care services including postpartum family planning in Kenya," FRONTIERS Final Report. Washington, DC: Population Council.

Nawar, L. et al. 2003. "Assessment of pilot health project outcome indicators: West Bank/Gaza," FRONTIERS Final Report. Washington, DC: Population Council.

Population Council. 2007. "Ethical Issues in Reproductive Health," Studies in Family Planning, $38(4)$.

Postabortion Care Consortium Community Task Force. Essential Elements of Postabortion Care: An Expanded and Updated Model. Postabortion Care Consortium. July 2002.

http://www.pac-consortium.org/site/

PageServer?pagename $=P A C \_$Model

Quiterio et al. 2008. "Situation analysis of the integration of family planning services in postpartum, postabortion and prevention of mother to child transmission programs in the Dominican Republic," FRONTIERS Final Report. Washington, DC: Population Council.

Ramarao, S. et al. 2007. "Assessment of the extension of postabortion care services in Senegal," FRONTIERS Final Report. Washington, DC: Population Council. 
Rivero-Fuentes, E. et al. 2008. "Situation analysis of the integration of family planning services in postpartum, postabortion and prevention of mother to child transmission programs in Haiti," FRONTIERS Final Report. Washington, DC: Population Council.

Solis, F. et al. 2008. "Situation analysis of the integration of family planning services in postpartum, postabortion and prevention of mother to child transmission programs in Nicaragua," FRONTIERS Final Report. Washington, DC: Population Council.

Vernon, R. 2008. "Meeting the family planning needs of postpartum women," FRONTIERS Program Brief No. 10. Washington, DC: Population Council.

Vernon, R., J. Foreit, and E. Ottolenghi. 2008. "Introducing systematic screening to reduce unmet health needs: A manager's manual," FRONTIERS Manual, revised edition. Washington, DC: Population Council.
WHO. 2002. WHO Antenatal Care Randomized Trial: Manual for the Implementation of the New Model. Geneva: World Health Organization.

WHO. 2008. "Integrated health services. What and why?" Technical Brief No. 1. Geneva: World Health Organization.

WHO, UNFPA, UNAIDS, and IPPF. Sexual and Reproductive Health \& HIV/AIDS. A Framework for Priority Linkages. October 2005. http://www.who.int/reproductive-health/stis/ framework.html

Youssef, H. et al. 2007. "Linking family planning with postabortion services in Egypt: Testing the feasibility, acceptability and effectiveness of two models of integration," FRONTIERS Final Report. Washington, DC: Population Council. 


\section{Appendix 1: Examples of the use of AIM to guide and evaluate integration of FP and other services}

\section{Use of AIM in the Dominican Republic to assess the integration of FP and antenatal care, postnatal care, postabortion care, and the prevention of mother-to-child transmission of} HIV. The Population Council and CESDEM, a Dominican private, nonprofit research organization, used AIM in a diagnostic study of the provision and use of contraception in postnatal, postabortion, and PMTCT programs in the Dominican Republic. The objectives of the study were to assess (a) the contraceptive knowledge, attitudes, and behaviors of providers and clients; (b) the degree to which information, counseling, and delivery are implemented in postnatal, postabortion, and PMTCT services; and (c) the quality of these services and the readiness of postnatal, postabortion, and PMTCT services to offer contraceptive services. The study, which had a national scope, covered 59 public facilities at the primary, secondary, and tertiary level.

The study showed that FP services are integrated with antenatal, delivery, and postnatal care in most of the health units visited and, to a lesser degree, to the integral care provided for persons living with HIV. However, a strong limitation was the lack of integration of counseling during ANC with the provision of methods at the hospitals and maternities after delivery. The study resulted in several recommendations to improve the quality of the services and its integration with FP, including, among others: (1) to design an information system to help identify women who decide during ANC that they want to start using an IUD or undergo sterilization before discharge; (2) to systematically screen outpatient service clients for FP needs; and (3) to increase the integration of FP with services at Integral Care Units (ICUs), either by arranging frequent visits by FP providers to the ICU or by training the ICU providers to screen for FP needs and provide contraceptive technology or refer clients to contraceptive service delivery sites.
See $h t t p: / / w w w . p o p c o u n c i l . o r g / p d f s /$ frontiers $/ F R$ FinalReports/DR_FP.pdf for more information on this project.

\section{Use of AIM to test the feasibility, acceptability, effect, and cost of integrating HIV C\&T with FP services in Kenya. In} Kenya, AIM was used to pilot-test two models of integration of HIV C\&T into existing FP services. In one model, FP clients were educated about HIV prevention generally, and C\&T in particular, and they were offered HIV C\&T during this consultation by the FP provider. In the second model, FP clients were educated about HIV C\&T, and those interested were instead referred to a specialized C\&T service, either within the same facility or at another health facility or a stand-alone VCT center.

A pre-post intervention design was used to obtain information about the effect of both models on the use and quality of services and their feasibility, acceptability, and costs. The study demonstrated that both models were feasible and acceptable to providers and to clients as means of integrating HIV prevention counseling, condom promotion, and C\&T with FP services, and both models were effective in increasing quality of care and service utilization. The majority of facilities had the capacity to integrate HIV prevention counseling and provision or referral for C\&T services within existing FP services, and the costs of the integration were affordable. Provision of both services jointly was perceived by clients to be beneficial and attractive and was welcomed by providers as an opportunity to provide a comprehensive service that better meets their clients' needs. Furthermore, significant improvements were observed in the quality of $\mathrm{FP}$ counseling and the discussions about HIV C\&T during the FP consultations.

See $h t t p: / / w w w . p o p c o u n c i l . o r g / p d f s / f r o n t i e r s /$ FR_FinalReports/Kenya_CT_FP.pdffor more information on this project. 
3. Use of AIM to assess the acceptability and feasibility of introducing the WHO-focused antenatal care package in Ghana. The main objective of this study, undertaken by Noguchi Memorial Institute for Medical Research in collaboration with the Population Council, was to examine the extent to which adaptation of the WHO's FANC package influenced the quality of care received by pregnant women and was acceptable to both providers and clients. AIM was used to collect information on the clinics where FANC had been introduced and four comparison clinics. Results showed that the FANC package was well accepted by both clients and providers because of its comprehensiveness and the individualized care. Some components of the package were lacking in several clinics, in particular procedures for disease detection (e.g., testing for syphilis and HIV/AIDS). Existing opportunities for referral were also not fully utilized. Clients visiting the intervention clinics obtained more comprehensive care than those visiting the comparison clinics. However, despite the fact that the FANC package recommends FP counseling to each ANC client, introduction of FANC had no effect on the integration of ANC and FP services.

See http://www.popcouncil.org/pdfs/frontiers/ FR_FinalReports/ghana_who_anc.pdf for more information on this project.

\section{Use of AIM to assess the extension of postabortion care services in Senegal.}

In 2006, AIM was used to assess the expansion of PAC services to the primary health-care level in Senegal. From November 2003 to June 2005, Management Sciences for Health (MSH) partnered with the MOH to extend PAC services in 23 Health Districts in the 5 regions in the country. The PAC model that was promoted in this expansion included FP services and counseling, and integration with other reproductive health services. The study, conducted in 2006, had three overarching objectives: (1) to assess the achievements of USAID PAC Working Group's financial investments in the extension of PAC services in Senegal; (2) to assess the extent to which the MSH-supported extension of PAC services has occurred; and
(3) to document the existing model of services, lessons, and challenges that would inform national and global replication and scale-up efforts. During the study, AIM methodology was used to collect information on seven health centers, seven health posts, two health huts, and two regional hospitals across four regions. In addition, the study included interviews with 23 key stakeholders and FGDs with community members, including adults and youth of both genders. Results showed that one limitation to providing FP services to PAC clients was the lack of FP methods available at the site where emergency services were provided.

See http://www.popcouncil.org/pdfs/frontiers/ FR_FinalReports/Senegal_PACAssess.pdf for more information on this project. 


\section{Appendix 2: Key steps in a typical AlM study}

\section{Define the objectives of the study in collaboration with $\mathrm{MOH}$ directors, program managers, donors, and other partners. This process also should involve defining the services and type of facilities that will be included in the study.}

\section{Collect information on the location, level} of care, and type of all health facilities in the country or region of interest. If possible, also gather information on the number of clients served in each facility.

3. Define the sample of facilities that will be included in the study.

4. Collect background documents that describe the level of integration of services, such as past assessments and any existing norms and protocols on service provision.

5. Make an initial data analysis plan. Define the key indicators that you want to measure and the disaggregated or comparisons that are of interest. For example, in an AIM study on the integration of HIV C\&T into FP services, you may want to measure what percentage of facilities offer HIV $\mathrm{C} \& \mathrm{~T}$ to their FP clients and how this varies between public and private institutions.

6. Once the key indicators have been identified, prepare the data collection instruments from those presented in this handbook, select items that are pertinent to the objectives of the study, discard any items or modules that are not relevant, and adapt the instruments, if necessary, to the local context and language.

7. Write a research protocol describing the study. Submit the protocol to the relevant IRBs and ERCs. Revise the research protocol according to the comments of the IRBs and ERCs.

8. Request letters of support from the MOH or other partner agencies to facilitate the research team's access to the facility. The letters should explain the objectives of the study and state that a team of researchers will be visiting the facility during a range of possible dates. The letters also should describe briefly what will happen during the research team's visit, emphasizing that the team will minimize any disturbance to the providers and maintain the privacy and confidentiality of providers and clients. Two copies of each letter should be produced: one to be mailed to the facility and one to be kept by the field supervisors and carried with them during their visits.

\section{Recruit two or three of the persons with experience in health surveys to serve as} supervisors. They also can conduct a pretest of the interviews in two or three nonsampled health facilities to test interviewee comprehension, willingness to answer questions, and the amount of time required for the interviews. Supervisors will usually train the interviewers, allocate them to facilities, explain the study objectives to facility managers, obtain their permission to collect data, supervise the research team, review completed instruments to verify validity, and assist interviewers if problems arise.

\section{Determine how many data collection} teams and field supervisors will be needed for the study based on the location and number of facilities in the sample, the mean number of clients served in each facility, and the time required for interviews and other tasks.

\section{Recruit the data collection teams and} field supervisors who will conduct the study. Organize and conduct a training workshop for the complete research team; everyone who will be involved in the research should attend the workshop, including field supervisors, data collection teams, data entry personnel, and data analysts. In this training, the team should become familiar with the objectives of the study and the concepts and procedures of ethical research, acquire skills in selecting and approaching the interview subjects, and learn how to use all the data collection instruments. The training also should serve to organize the travel logistics and the administrative and financial issues of the data collection teams. A sample training schedule for an eight-day workshop is given in Box 2 . 
12. Require that field supervisors visit each of the facilities before data collection begins (if the budget allows). In addition to meeting with the facility managers to request their support for the study, field supervisors should collect information about the exact location of the facility, the distance between facilities, the condition of the roads, and the flow of patients. This information should be used for planning the time that each data collection team will stay in each location, where will they reside, and where interviews of clients can take place.

\section{Include a minimum of three} persons in the data collection teams visiting each facility: at least one person with clinical training, one person with a social science training, and one person with interviewing experience. Those with a clinical background should conduct the observations of client-provider interactions and the service inventories, while those with a social science background are best suited to conduct the client and provider interviews. Data collection teams need to arrive at the facility early in the morning, before services start. Priority should be allocated to observing the consultations and interviewing the clients. If possible, the facility inventory and provider interviews should be carried out simultaneously or at times when the providers are less busy, which is usually in the afternoon.

\section{Require that supervisors} visit each facility under their supervision at least once during data collection to detect and help solve any problems and to reallocate interviewers between facilities if progress is too slow.

Box 2.
15. Identify situations where the team may need to stay longer than one day, for example, when AIM is used to assess integration of services that are relatively rare, such as PAC and delivery. Some studies have situated a data collection team in a convenient location so that they can be "on call" and ready to move between facilities when an appropriate client becomes available. When measuring the integration of FP with services that are provided around the clock, such as PAC and delivery, it may be necessary to have team members working on shifts or working alternative days and nights over several days.

Sample training schedue for an 8-day workshop

\begin{tabular}{|c|c|}
\hline Day & Activities \\
\hline One & $\begin{array}{l}\text { Introductions } \\
\text { Training plans } \\
\text { Objectives of the study } \\
\text { Research plan }\end{array}$ \\
\hline Two & $\begin{array}{l}\text { Concepts of reliability, validity and overview of data collection } \\
\text { Overview of the instruments } \\
\text { Principles of ethical research }\end{array}$ \\
\hline Three & $\begin{array}{l}\text { Review of the Observation Guide instrument } \\
\text { Review of the Client Exit Interview instrument }\end{array}$ \\
\hline Four & $\begin{array}{l}\text { Review of the Provider Interview instrument } \\
\text { Review of the Inventory instrument } \\
\text { Plenary meeting to discuss issues arising from instrument } \\
\text { reviews }\end{array}$ \\
\hline Five & $\begin{array}{l}\text { Guidelines for conducting good interviews } \\
\text { Break into specialized groups of interviewers and observers } \\
\text { Review administration of specific instruments for each group }\end{array}$ \\
\hline Six & $\begin{array}{l}\text { Role-playing to practice the instruments } \\
\text { Plenary meeting to discuss role-playing experiences }\end{array}$ \\
\hline Seven & $\begin{array}{l}\text { Review of supervisory roles with Field Supervisors } \\
\text { Break into research groups } \\
\text { Each team plans its travel logistics }\end{array}$ \\
\hline Eight & $\begin{array}{l}\text { Plenary meeting to discuss group plans } \\
\text { Administrative and financial issues }\end{array}$ \\
\hline
\end{tabular}


16. Require that supervisors meet with the data collection teams at the end of each day and review the data collection instruments. This review is an excellent opportunity to revise any inconsistencies in the responses, while the observations and interviews are still fresh in the memory, or go back to the facility and reexamine data that seems erroneous.

17. After data have been collected, create codes for open-ended questions, code data, write a data entry program, and enter the data. Clean the data by verifying that the responses for all items in the databases include only permissible values.

\section{Estimate frequencies for all items}

and determine whether the responses seem reasonable. In suspicious cases, review that the data were coded correctly and that there were no mistakes in the data entry program.
19. Plan a way to present the data that is not too technical and communicates findings in a way that allows their programmatic implications to be identified clearly. Consider which indicators to present in a table and which to present graphically. Determine which indicators to compare across different groups.

\section{Analyze the data, and prepare a draft report} and a presentation.

\section{Hold a data interpretation meeting to} present the preliminary findings to program managers, donors, and other stakeholders. Use this and subsequent follow-up meetings to identify the key conclusions to be drawn from the data, develop programmatic recommendations, and plan for how the findings can be used in decisions concerning service integration. 


\section{Appendix 3: FRONTIERS projects using AIM}

\section{FP/MCH/HIV Integration}

Dominican Republic (11/05 - 4/07)

Centro de Estudios Sociales y Demograficos, A.C. (CESDEM)

- To assess the use of family planning in postpartum, postabortion, and prevention of mother-to-child transmission of HIV (PMTCT) services

http://www.popcouncil.org/frontiers/projects/lac/DomRep_Contra.htm

Nicaragua (11/05-4/07)

Consultoria y Asesoria (ALVA)

- To assess the use of family planning in postpartum, postabortion, and prevention of mother-to-child transmission of HIV (PMTCT) services

http://www.popcouncil.org/frontiers/projects/lac/Nicaragua_PMTCT.htm

Haiti (01/06 - 03/07)

Centre d'Evaluation et de Recherche Apliquee (CERA)

- To assess the use of family planning in postpartum, postabortion, and prevention of mother-to-child transmission of HIV (PMTCT) services

http://www.popcouncil.org/frontiers/projects/lac/Haiti_PMTCT.htm

India (03/01 - 03/03)

Employees' State Insurance Corporation (ESIC), Taylor Nelson Sofres Mode Pvt. Ltd. (MODE)

- To assess the effect of male involvement in ANC and at postpartum on FP uptake and STI prevention http://www.popcouncil.org/frontiers/projects/ane/India_MiM.htm

Kenya (09/06 - 03/08)

Jhpiego/ACCESS-FP, Ministry of Health

- To develop, introduce, and assess the acceptability and feasibility of a strengthened postnatal care package that consists of four postnatal visits and integrated FP counseling

http://www.popcouncil.org/frontiers/projects/afr/Kenya_StrengthenPostnatal.htm

Lesotho (01/06 - 05/08)

Ministry of Health and Social Welfare

- To test the feasibility and effect of a strengthened postpartum care package that includes syphilis screening and management; HIV testing, counseling, and PMTCT; and discussion of postpartum FP and STI prevention counseling

http://www.popcouncil.org/frontiers/projects/afr/Lesotho_PMTCT.htm

Kenya (06/04 - 06/05)

Institute of African Studies, University of Nairobi

- To assess the Kenyan MOH's adaptation of the WHO ANC package, the effect of the model on service quality and coverage, and its sustainability

http://www.popcouncil.org/frontiers/projects/afr/Kenya_ANCPackage.htm

Ghana (10/04 - 08/05)

Noguchi Memorial Institute for Medical Research

- To assess the implementation and effects of the government's 2003 ANC policy

http://www.popcouncil.org/frontiers/projects/afr/Ghana_ANCPackage.htm 
South Africa (04/02 - 06/04)

Reproductive Health Research Unit, University of the Witwatersrand, Ministry of Health

- To develop and test an improved and integrated ANC program that increases the range and quality of services provided to ANC clients in public clinics

http://www.popcouncil.org/frontiers/projects/afr/SouthAfrica_ANCCostAnalysis.htm

\section{West Bank/Gaza (03/01 - 03/02)}

Center for Development in Primary Health Care (CDPHC)

- To create a service strategy that increases postpartum use of health care services by first-time mothers or women with one or two children

http://www.popcouncil.org/frontiers/projects/ane/WBGaza_Postpartum.htm

\section{PAC/FP Integration}

Bolivia (05/99 - 06/01)

Ipas, Ministry of Health

- To test improvements in the delivery of postabortion care (PAC) in public hospitals in Bolivia http://www.popcouncil.org/frontiers/projects/lac/Bolivia_TestingModel.htm

\section{Egypt (08/04 - 08/06)}

Tahseen/Catalyst Project, Ministry of Health

- To measure acceptability and cost-effectiveness of offering FP counseling to PAC clients through two models of integration

http://www.popcouncil.org/frontiers/projects/ane/Egypt_FP_PACLinks.htm

Tanzania (09/05 - 10/06)

ACQUIRE Project, Ministry of Health

- To assess the feasibility of decentralizing PAC services at lower-level facilities in rural areas http://www.popcouncil.org/frontiers/projects/afr/Tanzania_PACAssess.htm

\section{FP/C\&T Integration}

South Africa (07/04-09/07)

Department of Health

- To determine the feasibility and cost effectiveness of integrating HIV C\&T services with FP counseling in two different models: one in which C\&T referrals were made based on an STI risk assessment as part of FP counseling, and another in which the C\&T services were offered on-site http://www.popcouncil.org/frontiers/projects/afr/SouthAfrica_ANCCostAnalysis.htm

\section{Kenya (08/05 - 01/08)}

Ministry of Health

- To determine the feasibility and cost effectiveness of integrating HIV C\&T services with FP counseling in two different models: one in which C\&T referrals were made based on an STI risk assessment as part of FP counseling, and another in which the C\&T services were offered on-site

http://www.popcouncil.org/frontiers/projects/afr/Kenya_HIVFPIntegration.htm 


\section{Data collection instruments for the integration of family planning and antenatal care services}

This section contains the four basic instruments for conducting an AIM on the integration of family planning and ANC services. Instruments are presented in the following order:

\section{A) Inventory for facilities available and services provided at the facility \\ B) Observation guide \\ C) Questionnaire for clients' exit interviews \\ D) Questionnaire for providers' interviews}

Since some may be interested in using AIM to gather information exclusively about the integration of ANC and FP services, while others may want to take advantage of a research team already visiting the facility to obtain information about the general quality of ANC, the instruments below contain questions that are relevant for both purposes. The first two modules of the inventory and the observation guide and the first three modules of the provider's and client's interviews are designed to serve as a questionnaire that can easily be adapted to any study that focuses exclusively on measuring the integration of antenatal and FP services.

All the modules that follow the one labeled "Integration of Antenatal Care and Family Planning Services" are designed to assess different components of the quality of ANC services. Those interested in this aspect can adapt the whole instruments to their own context. Some of the questions in these modules are relevant only in certain contexts or for specific objectives, such as those that refer to the activities PMTCT of HIV and STIs, or the questions about costs. These optional questions are shaded for easy identification.

We recommend that only those questions that are directly linked to the objectives of each study (as defined by the researchers) are included in the final questionnaires. Otherwise, research teams risk wasting money and time collecting too much information that will not be used.

\section{A) Inventory for facilities available and services provided at the facility}

\section{INSTRUCTIONS TO DATA}

COLLECTOR: This inventory should be completed by observing the facilities that are available and having discussions with the person in charge of ANC on the day of the visit. For some questions, you may also have to talk to the person in charge of FP.

For some of the questions in this instrument, you will have to observe directly the availability of equipment, supplies, and infrastructure. Ask the clinic staff member who is assisting you to direct you to the room, laboratory, or storage area that you need to verify the availability of each item. In all cases, you should verify that the items exist by actually observing them yourself; if you are not able to observe them, then code accordingly. Remember that the objective of the inventory is to identify equipment and facilities that currently exist and are in working order and not to evaluate the performance of the staff or the clinic. For each item, circle the code of the most suitable response or describe as appropriate. Before beginning, read the following greeting when you meet with the staff person who will help you complete the inventory.

GREETING: Good morning. My name is , and I work for

We are currently doing a study about the way that family planning services are being integrated with ANC in the country and the problems that interfere with integration. This is not an evaluation of this facility or of the staff who provide us this information. We are visiting a number of facilities. All the information will be combined, and all the information you provide me will be confidential. No one will know what you said. Are you willing to assist? 
1. Facility identification

\begin{tabular}{|c|c|c|c|}
\hline No. & QUESTIONS & \multicolumn{2}{|l|}{ CODING CATEGORIES } \\
\hline 1.1 & Date of observations & \multicolumn{2}{|l|}{ 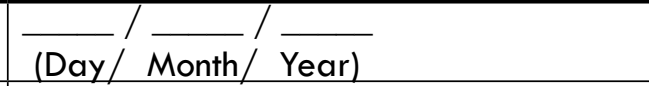 } \\
\hline 1.2 & Facility name & \multicolumn{2}{|l|}{ (Day/ Month/ Year) } \\
\hline 1.3 & City or locality & & \\
\hline \multirow[t]{7}{*}{1.4} & \multirow[t]{7}{*}{ Type of facility } & Hospital & 1 \\
\hline & & Health center with maternity ward & 2 \\
\hline & & $\begin{array}{l}\text { Health center without maternity } \\
\text { ward }\end{array}$ & 3 \\
\hline & & Health post with maternity ward & 4 \\
\hline & & Health post without maternity ward & 5 \\
\hline & & Dispensary & 6 \\
\hline & & Other (specify): & 7 \\
\hline \multirow[t]{4}{*}{1.5} & \multirow[t]{4}{*}{ Type of sector } & Government & 1 \\
\hline & & NGO & 2 \\
\hline & & Private & 3 \\
\hline & & Other (specify): & 4 \\
\hline \multirow[t]{4}{*}{1.6} & \multirow[t]{4}{*}{ Result of the inventory } & Complete & 1 \\
\hline & & Incomplete & 2 \\
\hline & & Refused & 3 \\
\hline & & Other (specify): & 4 \\
\hline
\end{tabular}

2. Questions to measure the integration between FP and ANC

\begin{tabular}{|c|c|c|c|c|c|}
\hline \multirow{3}{*}{\begin{tabular}{|l|} 
No. \\
2.1
\end{tabular}} & QUESTIONS & \multicolumn{3}{|c|}{ CODING CATEGORIES } & $\mathrm{GO} \mathrm{TO}$ \\
\hline & \multicolumn{4}{|c|}{$\begin{array}{l}\text { Is (read } 1 \text { to } 3 \text { ) available to outpatient clients in this health facility? How many days per } \\
\text { week are (read } 1 \text { to } 3 \text { ) services offered? }\end{array}$} & \\
\hline & & Yes & No & Days & \\
\hline & 1) FP counseling & 1 & 2 & & \\
\hline & 2) Contraceptives & 1 & 2 & & \\
\hline & 3) $\mathrm{ANC}$ & 1 & 2 & & \\
\hline \multirow[t]{4}{*}{2.2} & \multirow{4}{*}{$\begin{array}{l}\text { Do the hours of operation of ANC } \\
\text { coincide with the hours of operation } \\
\text { of FP services? }\end{array}$} & \multirow{2}{*}{\multicolumn{2}{|c|}{$\begin{array}{l}\text { Yes. Whenever ANC services are } \\
\text { open, FP services are also open. } \\
\text { Sometimes. There are times when } \\
\text { ANC services are open that FP } \\
\text { services are closed. Explain: }\end{array}$}} & 1 & \\
\hline & & & & 2 & \\
\hline & & \multirow{2}{*}{\multicolumn{2}{|c|}{$\begin{array}{l}\text { No. Whenever ANC services are } \\
\text { open, FP services are closed. } \\
\text { Other: }\end{array}$}} & 3 & \\
\hline & & & & 4 & \\
\hline
\end{tabular}




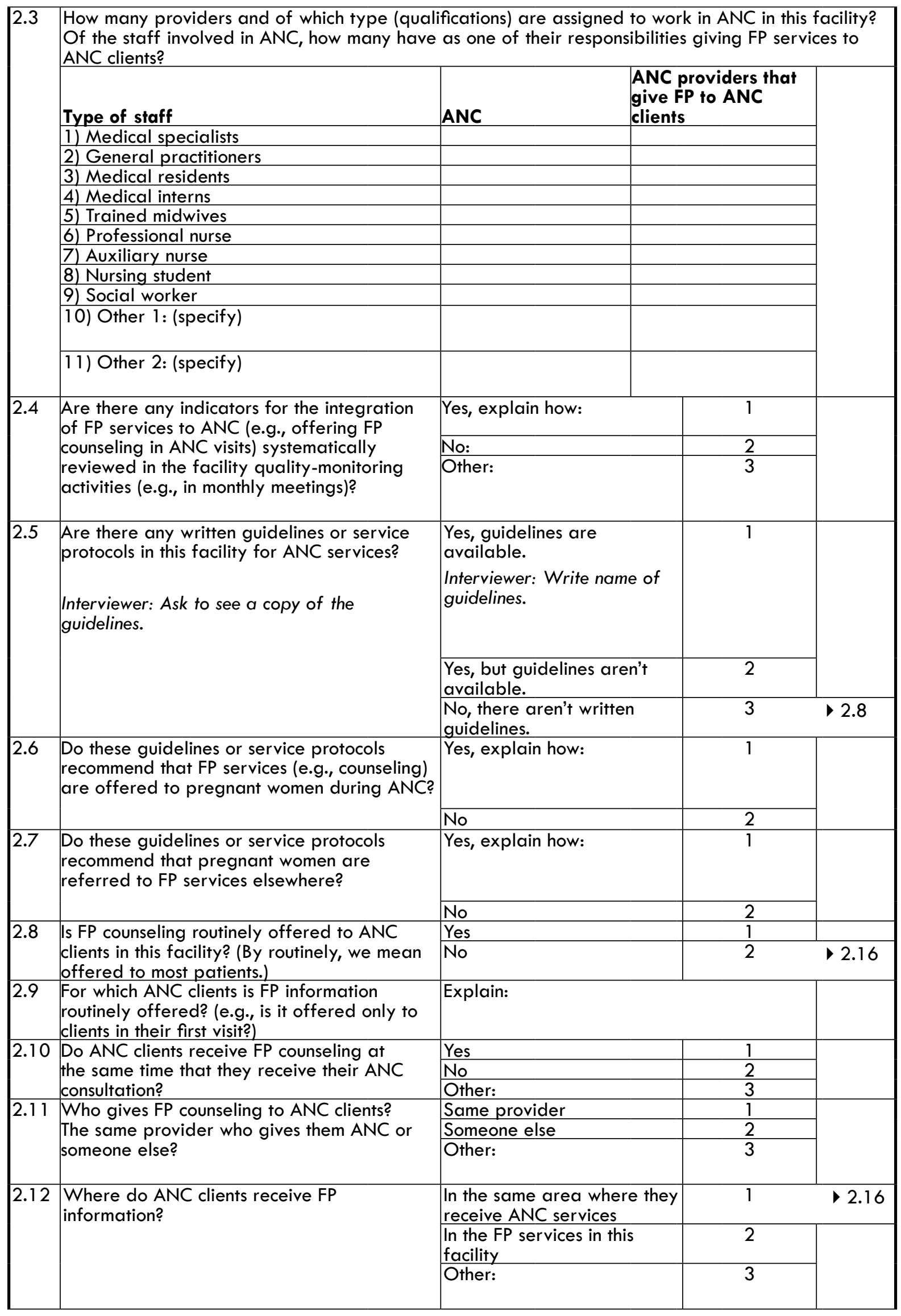




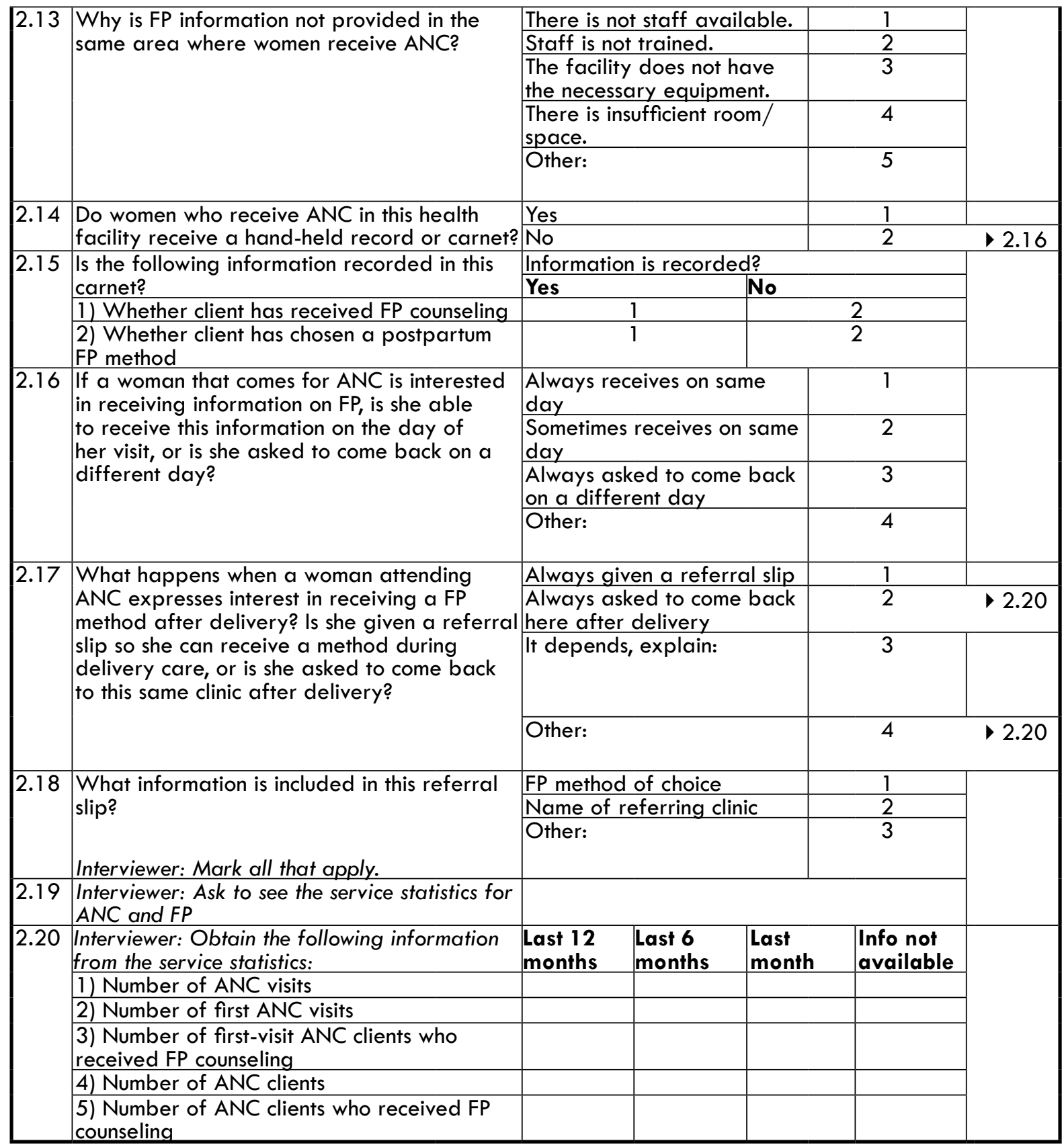

\section{Description of the service area}

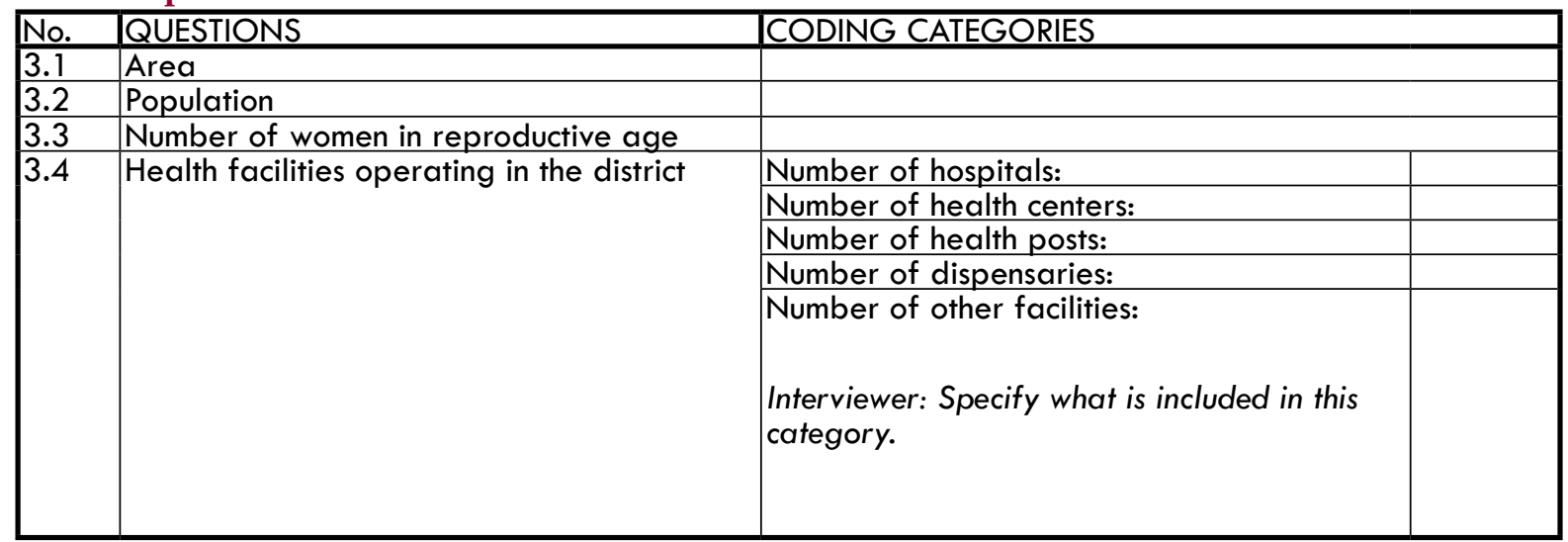




\section{Hours of operation}

\begin{tabular}{|c|c|c|c|c|}
\hline No. & QUESTIONS & \multicolumn{3}{|c|}{ CODING CATEGORIES } \\
\hline 4.1 & $\begin{array}{l}\text { Routinely, how many days per week is the } \\
\text { facility open for outpatient services? }\end{array}$ & \multicolumn{3}{|l|}{ Days: } \\
\hline 4.2 & $\begin{array}{l}\text { What are the opening and closing times for } \\
\text { outpatient services at this facility? }\end{array}$ & \multicolumn{3}{|c|}{$\begin{array}{ll}\text { Opening time } & \\
\text { Closing time } & : \\
& \text { (Hour }: \text { Minutes) }\end{array}$} \\
\hline \multirow[t]{2}{*}{4.3} & \multirow{2}{*}{$\begin{array}{l}\text { Is there a nurse or doctor present at the facility } \\
\text { at all times? ( } 24 \text { hours/day) }\end{array}$} & Yes & & 1 \\
\hline & & No & & 2 \\
\hline 4.4 & $\begin{array}{l}\text { Is there a nurse or doctor available on call at al } \\
\text { times after hours? }\end{array}$ & \begin{tabular}{|l|} 
Yes \\
No \\
\end{tabular} & & 2 \\
\hline
\end{tabular}

5. Services available/staff

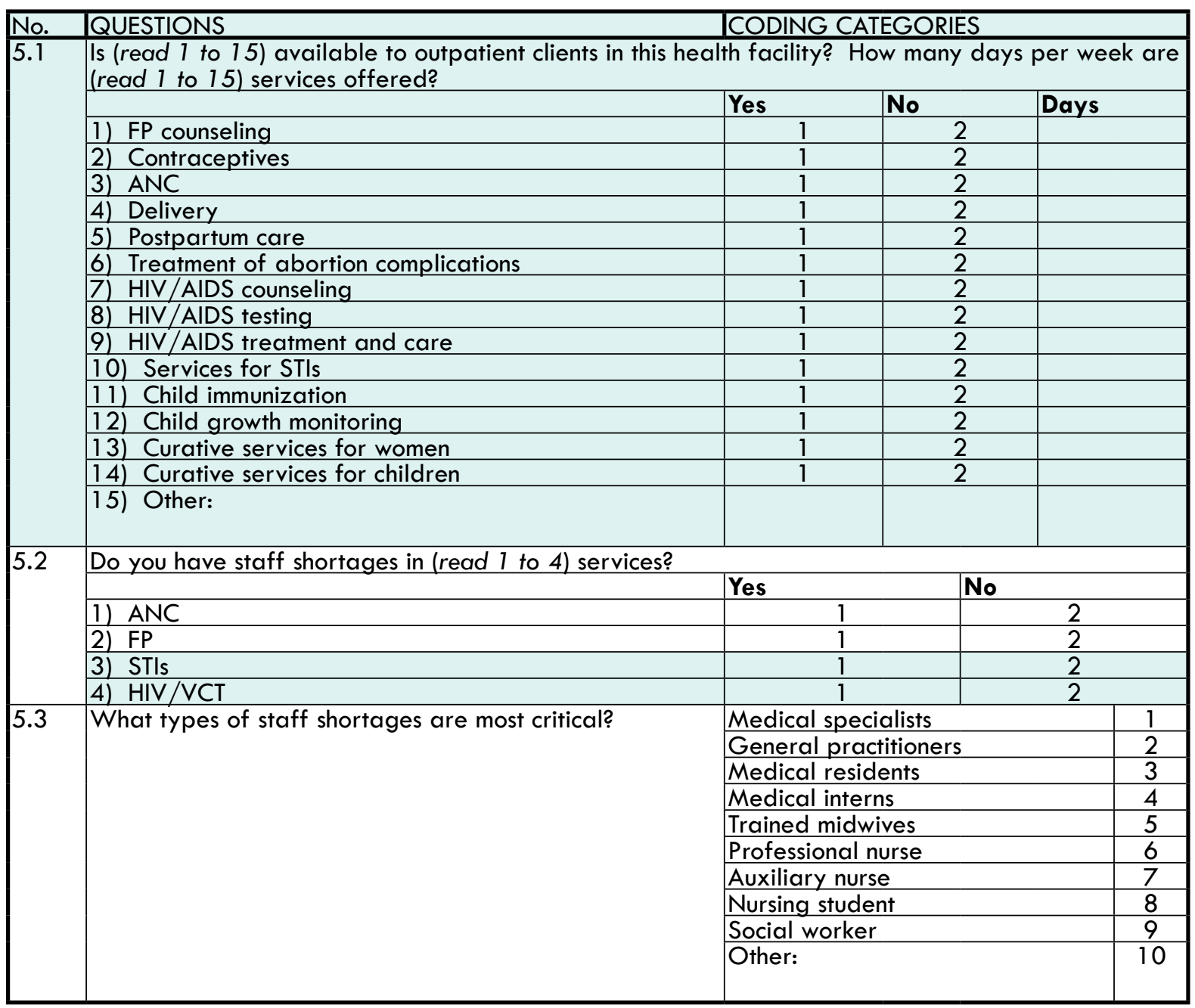


6. Supervision

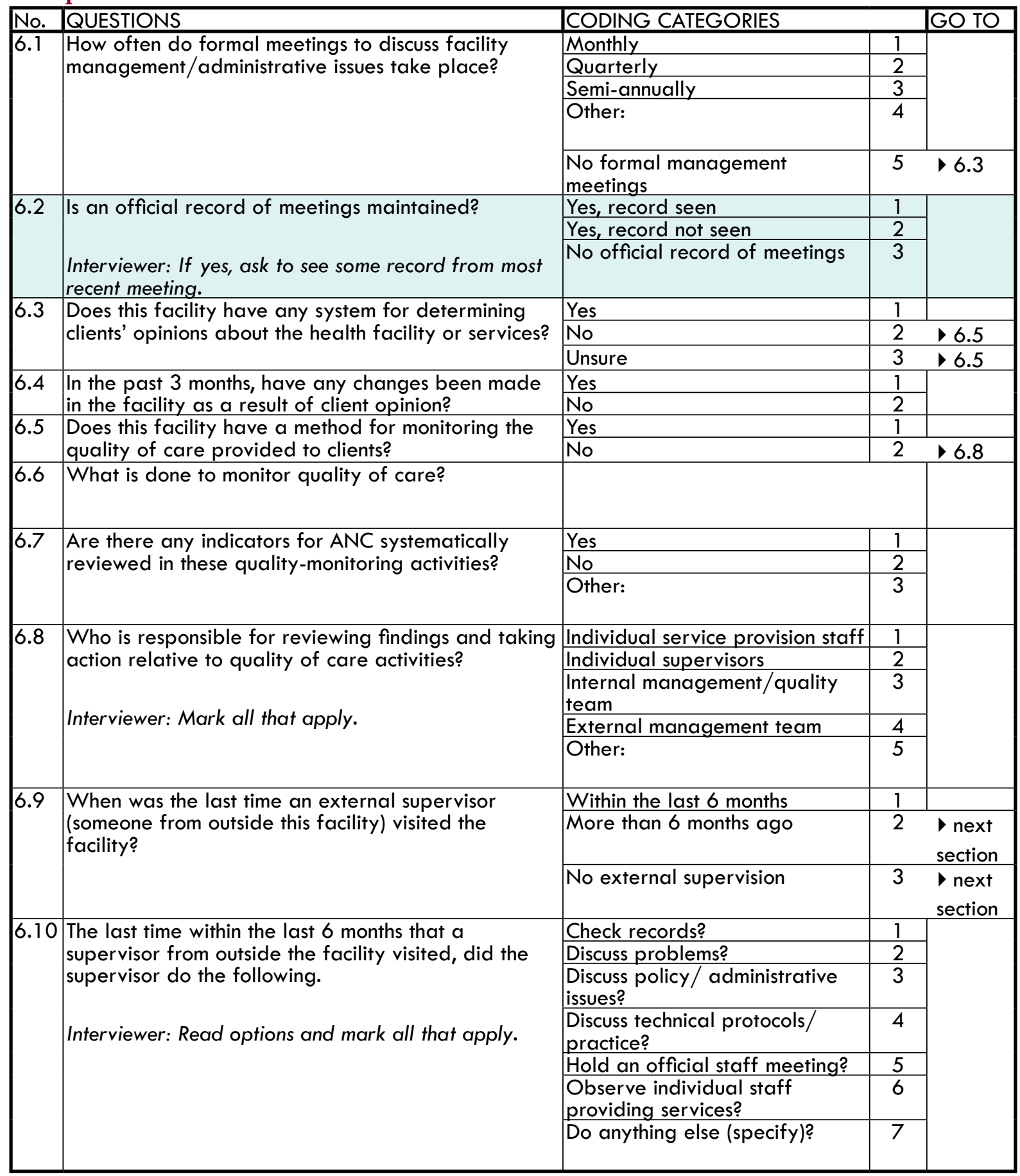


7. ANC quality

No. QUESTIONS

CODING CATEGORIES

GO TO

\begin{tabular}{|l|l|}
\hline 7.1 & $\begin{array}{l}\text { Does this facility have a routine system for } \\
\text { taking measurements of antenatal clients prior to } \\
\text { consultation? }\end{array}$ \\
\hline 7.2 & $\begin{array}{l}\text { Are tetanus toxoid vaccination services available } \\
\text { each day ANC services are provided? }\end{array}$ \\
\hline 7.3 & Whe \\
\hline
\end{tabular}

7.3 Where does this facility refer clients for delivery?

7.4 Which of the following services are routinely offered to ANC patients in this facility? (By routinely, we mean offered to most patients.) If a service is not routinely offered in this

facility, are ANC patients referred to a different health facility to obtain this service?

Interviewer: Read options.

Service

1) HIV/AIDS voluntary counseling

2) HIV/AIDS testing

3) Antiretroviral (ARV) prophylaxis treatment for

HIV-positive women

4) Syphilis screening and treatment

5) Other STls screening and treatment

6) Malaria screening and treatment

7) TB screening and detection

8) TB X-ray services

9) TB treatment services DOTS

\begin{tabular}{l|l}
7.5 & In the cases where ANC clients are referred
\end{tabular} elsewhere for some services, are they given a referral slip or coupon with information such as the name of the clinic to which they should go, the service they need, or any other information?

Interviewer: Ask to see a referral slip.

7.6 What information is included in the referral slip or coupon?

Interviewer: Mark all that apply.

\begin{tabular}{|l|l|}
\hline Yes & 1 \\
\hline No & 2 \\
& \\
\hline Yes & 1 \\
\hline No & 2 \\
\hline
\end{tabular}

Thviewer: Mark all that apply.

\begin{tabular}{l|l|}
7.7 & $\begin{array}{l}\text { Does staff working on ANC in the outpatient area of } \\
\text { this health facility have a directory or list of referral } \\
\text { services? }\end{array}$ \\
\cline { 2 - 3 }
\end{tabular}

\begin{tabular}{l|l}
7.8 & Is this referral list easily accessible to all staff
\end{tabular} working on ANC?

7.9 Are the following tests available to ANC clients in this health facility?

\begin{tabular}{|l|c|c|c|c|}
\hline Type of test & Conduct test & $\begin{array}{l}\text { Collect } \\
\text { specimen }\end{array}$ & $\begin{array}{l}\text { Test is } \\
\text { referred }\end{array}$ & $\begin{array}{l}\text { Test is not } \\
\text { referred }\end{array}$ \\
\hline 1) HIV/AIDS preliminary tests & 1 & 2 & 3 & 4 \\
\hline 2) HIV/AIDS confirmation tests & 1 & 2 & 3 & 4 \\
\hline 3) Syphilis & 1 & 2 & 3 & 4 \\
\hline 4) Gonorrhea & 1 & 2 & 3 & 4 \\
\hline 5) Test for blood anemia & 1 & 2 & 3 & 4 \\
\hline 6) Test urine for protein & 1 & 2 & 3 & 4 \\
\hline 7) Test urine glucose & 1 & 2 & 3 & 4 \\
\hline 8) Malaria & 1 & 2 & 3 & 4 \\
\hline 9) Blood group & 1 & 2 & 3 & 4 \\
\hline 10) TB & 1 & 2 & 3 & 4 \\
\hline 11) Cervical smear & 1 & 2 & 3 & 4 \\
\hline
\end{tabular}


8. Syphilis in ANC

\begin{tabular}{|c|c|c|c|c|}
\hline No. & QUESTIONS & CODING CATEGORIES & & GO TO \\
\hline 8.1 & Are syphilis tests... & Conducted & 1 & 8.5 \\
\hline & & Specimen collected & 2 & \\
\hline & Interviewer: Obtain answer from question 7.9-3. & Referred or not offered & 3 & $\begin{array}{l}\text { next } \\
\text { section }\end{array}$ \\
\hline 8.2 & How often are syphilis screening specimens & Once & 1 & \\
\hline & collected from the clinic (times per week)? & Twice & 2 & \\
\hline & & 3 times & 3 & \\
\hline & & More than 3 times & 4 & \\
\hline & & Other: & 5 & \\
\hline 8.3 & What is the longest interval between blood & 1 day & 1 & \\
\hline & being taken and the collection day (days)? & 2 days & 2 & \\
\hline & & 3 days & 3 & \\
\hline & & More than 3 days & 4 & \\
\hline 8.4 & What type of equipment do you use to store & Refrigerator & 1 & \\
\hline & specimens while waiting for collection? & Cold box & 2 & \\
\hline 8.5 & When are clients asked to return for syphilis & Next ANC appointment & 1 & \\
\hline & results? & 2 weeks & 2 & \\
\hline & & Other: & 3 & \\
\hline 8.6 & Does this clinic routinely provide syphilis test & Positive clients only? & 1 & \\
\hline & results to... & Both positive and negative? & 2 & \\
\hline & & Neither positive nor negative clients? & 3 & \\
\hline & $\begin{array}{l}\text { Interviewer: Read options until you get a positive } \\
\text { response. }\end{array}$ & & & \\
\hline 8.7 & Is there a mechanism for informing clients who & Yes & 1 & \\
\hline & do not return to ANC of test results? & No & 2 & 8.9 \\
\hline 8.8 & What is the mechanism? & & & \\
\hline 8.9 & How are partners of clients who tested positive & 1 dose without test & 1 & \\
\hline & for syphilis treated? & $\begin{array}{l}\text { Asked to come for } 3 \text { doses without } \\
\text { blood test }\end{array}$ & 2 & \\
\hline & & Blood test taken as well as first dose & 3 & \\
\hline & & $\begin{array}{l}\text { Blood test taken, and partner } \\
\text { treated on basis of result before } \\
\text { commencing treatment }\end{array}$ & 4 & \\
\hline & & Are not treated & 5 & \\
\hline & & Other: & 6 & \\
\hline
\end{tabular}

\section{PMTCT of HIV in ANC}

\begin{tabular}{|c|c|c|c|c|}
\hline No. & QUESTIONS & CODING CATEGOR & & GO TO \\
\hline 9.1 & Is HIV voluntary counseling conducted during ANC? & Yes & 1 & \\
\hline & Interviewer: Obtain answer from question 7.4-1. & No & 2 & 9.3 \\
\hline 9.2 & For whom is HIV voluntary counseling being offered? & All ANC clients & 1 & \\
\hline & & First ANC visits only & 2 & \\
\hline & & Other: & 3 & \\
\hline 9.3 & Is HIV voluntary testing conducted during ANC visits? & Yes & 1 & \\
\hline & Interviewer: Obtain answer from question 7.4-2. & No & 2 & $\begin{array}{l}\text { next } \\
\text { section }\end{array}$ \\
\hline 9.4 & For whom is HIV voluntary testing being offered? & All ANC clients & 1 & \\
\hline & & First ANC visits only & 2 & \\
\hline & & Other: & 3 & \\
\hline 9.5 & Is HIV voluntary testing conducted in an opt-in (women & Opt-in & 1 & \\
\hline & $\begin{array}{l}\text { receive pretest counseling and consent to an HIV test) or } \\
\text { an opt-out fashion (women are informed that an HIV test } \\
\text { will be conducted and they may refuse)? }\end{array}$ & Opt-out & 2 & \\
\hline
\end{tabular}




\begin{tabular}{|c|c|c|c|c|c|}
\hline \multirow{4}{*}{9.6} & \multirow{4}{*}{$\begin{array}{l}\text { What HIV tests are performed for pregnant women? } \\
\text { Interviewer: Mark all that apply. }\end{array}$} & \multirow{4}{*}{\multicolumn{2}{|c|}{\begin{tabular}{|l|} 
HIV rapid tests \\
ELISA \\
WB \\
Other:
\end{tabular}}} & 1 & \\
\hline & & & & 2 & \\
\hline & & & & 3 & \\
\hline & & & & 4 & \\
\hline \multirow[t]{3}{*}{9.7} & \multirow[t]{3}{*}{ When are antenatal clients given their HIV results? } & \multicolumn{2}{|c|}{ Same day } & 1 & \\
\hline & & \multicolumn{2}{|c|}{$\begin{array}{l}\text { Next ANC } \\
\text { appointment }\end{array}$} & 2 & \\
\hline & & \multicolumn{2}{|c|}{ Other: } & 3 & \\
\hline \multirow[t]{3}{*}{9.8} & \multirow{3}{*}{$\begin{array}{l}\text { Does this clinic routinely provide HIV test results to: } \\
\text { Interviewer: Read options until you get a positive response. }\end{array}$} & \multicolumn{2}{|c|}{ Positive clients only? } & 1 & \\
\hline & & \multicolumn{2}{|c|}{\begin{tabular}{|l|} 
Both positive and \\
negative?
\end{tabular}} & 2 & \\
\hline & & \multicolumn{2}{|c|}{$\begin{array}{l}\text { Neither positive nor } \\
\text { negative clients }\end{array}$} & 3 & \\
\hline \multirow[t]{2}{*}{9.9} & \multirow{2}{*}{$\begin{array}{l}\text { Is there a mechanism for informing clients who do not } \\
\text { return to ANC of test results? }\end{array}$} & \multicolumn{2}{|c|}{ Yes } & 1 & \\
\hline & & \multicolumn{2}{|l|}{ No } & 2 & 9.11 \\
\hline 9.10 & \multicolumn{3}{|l|}{ What is the mechanism? } & & \\
\hline \multirow[t]{2}{*}{9.11} & \multirow{2}{*}{$\begin{array}{l}\text { Is there a mechanism to notify the partners of the test } \\
\text { results? }\end{array}$} & \multirow{2}{*}{\multicolumn{2}{|c|}{\begin{tabular}{|l|} 
Yes \\
No \\
\end{tabular}}} & 1 & \\
\hline & & & & 2 & \\
\hline \multirow[t]{12}{*}{9.12} & $\begin{array}{l}\text { Interviewer: Obtain the following information from the } \\
\text { antenatal and FP records. }\end{array}$ & $\begin{array}{l}\text { Last } 12 \\
\text { months }\end{array}$ & $\begin{array}{l}\text { Last } 6 \\
\text { months }\end{array}$ & $\begin{array}{l}\text { Last } \\
\text { month }\end{array}$ & $\begin{array}{l}\text { Info not } \\
\text { available }\end{array}$ \\
\hline & \multicolumn{5}{|l|}{ PMTCT of HIV: } \\
\hline & \multicolumn{5}{|l|}{$\begin{array}{l}\text { 1) Number of ANC clients who received HIV/AIDS } \\
\text { counseling }\end{array}$} \\
\hline & \multicolumn{5}{|l|}{ 2) Number of ANC clients who were tested for HIV } \\
\hline & \multicolumn{5}{|l|}{ 3) Number of ANC clients who tested positive for HIV } \\
\hline & \multicolumn{5}{|l|}{$\begin{array}{l}\text { 4) Number of ANC clients who returned for their HIV } \\
\text { results }\end{array}$} \\
\hline & \multicolumn{5}{|l|}{ 5) Number of ANC clients who were tested for syphilis } \\
\hline & \multicolumn{5}{|l|}{ 6) Number of ANC clients who tested positive for syphilis } \\
\hline & \multicolumn{5}{|l|}{$\begin{array}{l}\text { 7) Number of ANC clients who returned for their syphilis } \\
\text { results }\end{array}$} \\
\hline & \multicolumn{5}{|l|}{ 8) Number of clients tested for HIV for all facilities } \\
\hline & \multicolumn{5}{|l|}{ 9) Number of new HIV-positive clients in the whole facility } \\
\hline & $\begin{array}{l}\text { 10) Number of HIV-positive antenatal women with CD4 } \\
\text { counts below } 200\end{array}$ & & & & \\
\hline
\end{tabular}

10. General infrastructure of the facility

\begin{tabular}{|l|l|c|}
\hline No. & QUESTIONS & CODING CATEGORIES \\
\hline 10.1 & $\begin{array}{l}\text { Interviewer: Observe the conditions and infrastructure in the facility and mark } \\
\text { if it has the following. }\end{array}$ & Yes \\
\hline 1) Piped running water & 1 & 2 \\
\hline 2) Electricity & 1 & 2 \\
\hline 3) Working latrines/toilets for clients & 1 & 2 \\
\hline 4) Working phone/short wave radio & 1 & 2 \\
\hline $\begin{array}{l}\text { 5) Transport vehicle in working order or standing arrangements for } \\
\text { transport in the case of emergencies }\end{array}$ & 1 & 2 \\
\hline 6) Clean facilities (e.g., the floors are swept, there is no dust in the desks) & 1 & 2 \\
\hline 7) Enough chairs or benches in waiting areas & 1 & 2 \\
\hline $\begin{array}{l}\text { 8) Waiting area for clients where they are protected from the sun, rain, } \\
\text { and snow }\end{array}$ & 1 & 2 \\
\hline
\end{tabular}


11. ANC counseling and examination rooms, equipment, and job aids

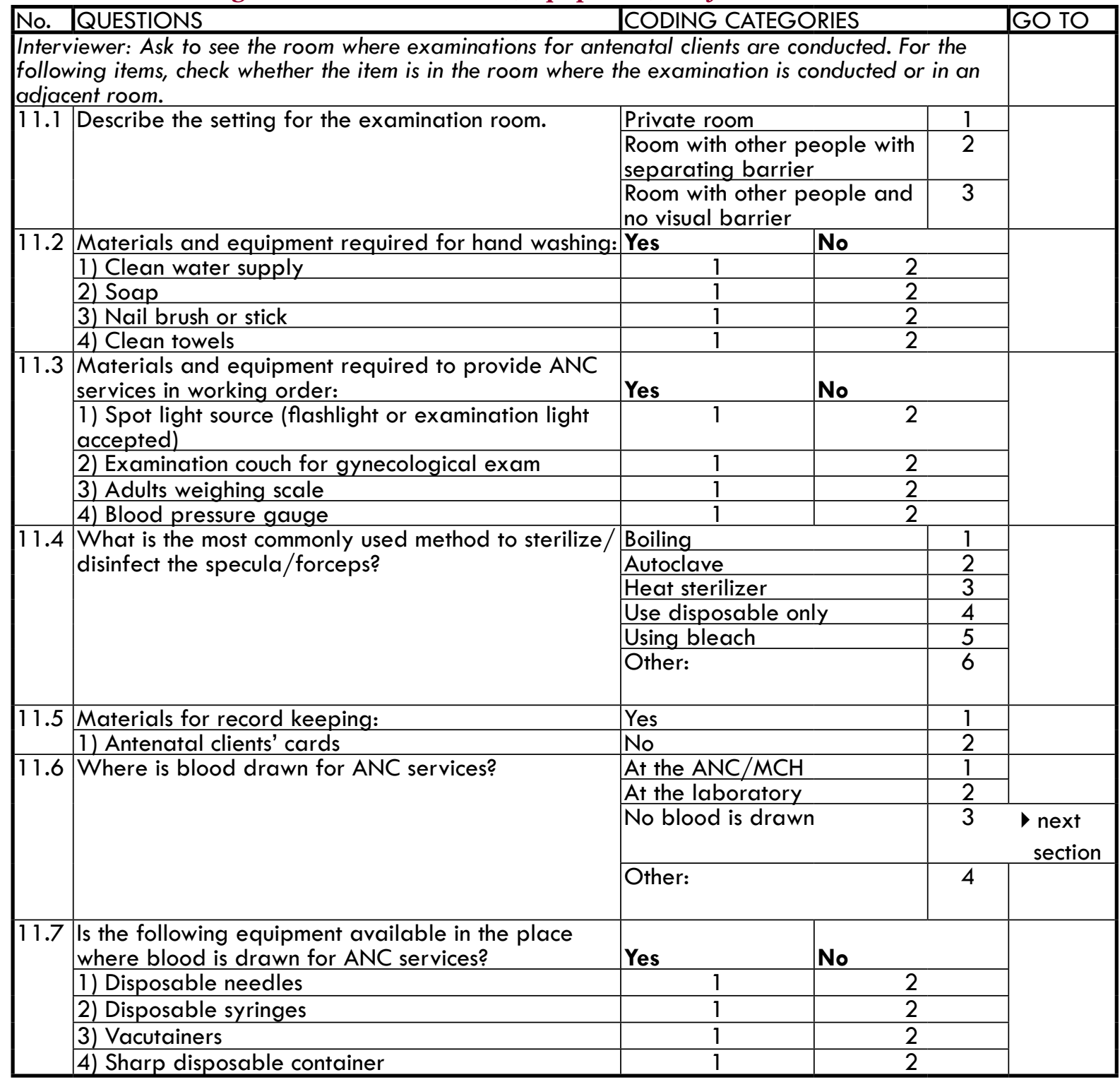

12. Information, education, and communication (IEC) materials

\begin{tabular}{|c|c|c|c|}
\hline \multirow{2}{*}{\multicolumn{2}{|c|}{$\begin{array}{l}\text { No. QUESTIONS } \\
\text { Interviewer: Verify that the following materials are available in the counseling } \\
\text { or the examination room. }\end{array}$}} & \multicolumn{2}{|c|}{ CODING CATEGORIES } \\
\hline & & Yes & No \\
\hline \multirow[t]{8}{*}{12.1} & Visual aids for teaching about: & & \\
\hline & 1) Different FP methods & 1 & 2 \\
\hline & 2) STIs & 1 & 2 \\
\hline & 3) HIV/AIDS & 1 & 2 \\
\hline & 4) PMTCT of HIV & 1 & 2 \\
\hline & 5) Model for demonstrating condom use & 1 & 2 \\
\hline & 6) Postpartum care/newborn care/breastfeeding & 1 & 2 \\
\hline & 7) Danger signs of complications in pregnancy & 1 & 2 \\
\hline \multirow[t]{6}{*}{12.2} & Information booklets/leaflets for clients to take home: & & \\
\hline & 1) On ANC & 1 & 2 \\
\hline & 2) On FP & 1 & 2 \\
\hline & 3) On HIV/AIDS & 1 & 2 \\
\hline & 4) On PMCT of HIV & 1 & 2 \\
\hline & 5) On STIs & 1 & 2 \\
\hline
\end{tabular}


13. Drugs, contraceptives, and reagents

No. QUESTIONS

CODING CATEGORIES

Interviewer: Ask to see where the following drugs/contraceptives/reagents are kept and mark, for each of them, if it is available on the day of your visit.

13.1 Antenatal care:

1) Folic acid

2) Ascorbic acid

3) Ferrous sulphate tabs

4) Tetanus toxoid injection

5) Tetanus antitoxin (antitetanus: immunoglobulan: human)

6) Combout

7) $\mathrm{BCG}$

8) Polio

9) Measles

10) DPT (Diphetheria Pertussis Tetanus)

11) $\mathrm{HIB}$

12) HBV (Hepatitis B Virus)

13) DT

14) Riger Lactate Solution

15) Magnesium Sulphate

16) Lexoprenaline

13.2 Contraceptives:

1) Combined oral contraceptives

2) Progestin-only pills

3) Emergency contraceptive pills (pre-packed)

4) Emergency contraceptive pills (not pre-packed)

5) Progestin-only injectables

6) Monthly injectables

7) Combined patches

8) Combined vaginal rings

9) Jadelle implants

10) Implanon implants

11) Sinoplant (II) implants

12) Copper-bearing intrauterine devices

13) IUD kits

14) Levonorgestrel intrauterine devices

15) Male condoms

16) Female condoms

17) Diaphragms

18) Spermicides

19) Female sterilization

20) Vasectomy

13.3 Sexually transmitted infections:

1) Erythromycin

2) Ciprobay

3) Flagyl

4) Metronidazole

5) Benzathine Penicillin

6) Doxycycline

7) RPR kits

13.4 ARV drugs:

1) Nevirapine (NVP)

2) Azidothymidine (AZT or ZDV) (Also known as Zidovudine or

Retrovir)

3) AZT syrup

4) Lamivudine (3TC)

5) Efavirenz (EFV)

6) Zidovudine + Lamivudine (Combivir)

7) Abacavir (ABC)

8) Stavudine (d4T)

9) Emtricitabine (FTC)

10) Atazanavir/ritonavir (ATV/r)

11) Didanosine (ddl)

12) Fosamprenavir/ritonavir (fos-APV/r)

13) Indinavir (IDV)

14) Lopinavir/ritonavir (LPV/r)

\begin{tabular}{|c|c|}
\hline Yes & No \\
\hline 1 & 2 \\
\hline 1 & 2 \\
\hline 1 & 2 \\
\hline 1 & 2 \\
\hline 1 & 2 \\
\hline 1 & 2 \\
\hline 1 & 2 \\
\hline 1 & 2 \\
\hline 1 & 2 \\
\hline 1 & 2 \\
\hline 1 & 2 \\
\hline 1 & 2 \\
\hline 1 & 2 \\
\hline 1 & 2 \\
\hline 1 & 2 \\
\hline 1 & 2 \\
\hline
\end{tabular}

No

\begin{tabular}{|c|c|}
\hline Yes & No \\
\hline 1 & 2 \\
\hline 1 & 2 \\
\hline 1 & 2 \\
\hline 1 & 2 \\
\hline 1 & 2 \\
\hline 1 & 2 \\
\hline 1 & 2 \\
\hline 1 & 2 \\
\hline 1 & 2 \\
\hline 1 & 2 \\
\hline 1 & 2 \\
\hline 1 & 2 \\
\hline 1 & 2 \\
\hline 1 & 2 \\
\hline 1 & 2 \\
\hline 1 & 2 \\
\hline 1 & 2 \\
\hline 1 & 2 \\
\hline 1 & 2 \\
\hline 1 & 2 \\
\hline Yes & No \\
\hline 1 & 2 \\
\hline 1 & 2 \\
\hline 1 & 2 \\
\hline 1 & 2 \\
\hline 1 & 2 \\
\hline 1 & 2 \\
\hline 1 & 2 \\
\hline Yes & No \\
\hline 1 & 2 \\
\hline 1 & 2 \\
\hline 1 & 2 \\
\hline 1 & 2 \\
\hline 1 & 2 \\
\hline 1 & 2 \\
\hline 1 & 2 \\
\hline 1 & 2 \\
\hline 1 & 2 \\
\hline 1 & 2 \\
\hline 1 & 2 \\
\hline 1 & 2 \\
\hline 1 & 2 \\
\hline 1 & 2 \\
\hline
\end{tabular}




\begin{tabular}{|c|c|c|c|}
\hline & 15) Nelfinavir (NFV) & 1 & 2 \\
\hline & 16) Rifampicin (RIF) & 1 & 2 \\
\hline & 17) Saquinavir/ritonavir (SQV/r) & 1 & 2 \\
\hline & 18) Tenofovir (TDF) & 1 & 2 \\
\hline & 19) Reagents for HIV tests & 1 & 2 \\
\hline \multirow[t]{9}{*}{13.5} & Tuberculosis: & Yes & No \\
\hline & 1) BCG vaccine & 1 & 2 \\
\hline & 2) H-Isoniazid & 1 & 2 \\
\hline & 3) R-Rifampicin & 1 & 2 \\
\hline & 4) Z-Pyrazinamide & 1 & 2 \\
\hline & 5) E-Ethambutol & 1 & 2 \\
\hline & 6) S-Streptomycin & 1 & 2 \\
\hline & 7) Contrimoxazale & 1 & 2 \\
\hline & 8) Reagents for TB test & 1 & 2 \\
\hline
\end{tabular}

\section{Record keeping}

\begin{tabular}{|c|c|c|c|c|c|}
\hline \multirow{3}{*}{\begin{tabular}{|l|} 
No. \\
14.1
\end{tabular}} & \multirow{3}{*}{$\begin{array}{l}\text { QUESTIONS } \\
\text { Is the following information recorded in the clinical history } \\
\text { of ANC clients? }\end{array}$} & \multicolumn{3}{|c|}{ CODING CATEGORIES } & \multirow[t]{2}{*}{ GO TO } \\
\hline & & \multicolumn{3}{|c|}{ Information is recorded? } & \\
\hline & & Yes & \multicolumn{2}{|l|}{ No } & \\
\hline & 1) Client's name & 1 & \multicolumn{2}{|l|}{2} & \\
\hline & 2) Date of last ANC visit & 1 & \multicolumn{2}{|l|}{2} & \\
\hline & 3) Gestational age at last ANC visit & 1 & \multicolumn{2}{|l|}{2} & \\
\hline & 4) Whether client has received FP counseling & 1 & \multicolumn{2}{|l|}{2} & \\
\hline & 5) Whether client has chosen postpartum FP method & 1 & \multicolumn{2}{|l|}{2} & \\
\hline & 6) Whether client has received HIV/AIDS counseling & 1 & \multicolumn{2}{|l|}{2} & \\
\hline & 7) Whether client has been tested for HIV/AIDS & 1 & \multicolumn{2}{|l|}{2} & \\
\hline & 8) Whether client has received syphilis counseling & 1 & \multicolumn{2}{|l|}{2} & \\
\hline & 9) Whether client has been tested for syphilis & 1 & \multicolumn{2}{|l|}{2} & \\
\hline & 10) Risk factors & 1 & \multicolumn{2}{|l|}{2} & \\
\hline & 11) Date of future ANC visit & 1 & \multicolumn{2}{|l|}{2} & \\
\hline \multirow[t]{2}{*}{14.2} & \multirow{2}{*}{$\begin{array}{l}\text { Is there a daily activity register for ANC services } \\
\text { provided in the outpatient area of this facility? }\end{array}$} & \multirow{2}{*}{\multicolumn{2}{|c|}{ Yes }} & 1 & \\
\hline & & & & 2 & end \\
\hline
\end{tabular}




\section{Costs}

\section{\begin{tabular}{l|l} 
No. QQUESTIONS & CODING CATEGORIES \\
\hline
\end{tabular}}

Interviewer: Ask questions 15.1 to 15.3 and register answers in the table below.

15.1 What are outpatient clients charged for obtaining the following services, commodities, tests, or procedures?

15.2 Is there a waiver or exemption policy for women who cannot pay?

15.3 Who is exempted from paying these fees?

\begin{tabular}{|c|c|c|c|c|}
\hline \multirow[t]{2}{*}{ Service or commodity } & \multirow[t]{2}{*}{$\begin{array}{l}15.1 \\
\text { Charge in local } \\
\text { currency }\end{array}$} & \multicolumn{2}{|c|}{$\begin{array}{l}15.2 \\
\text { Is there a waiver } \\
\text { or exemption } \\
\text { policy? }\end{array}$} & \multirow[t]{2}{*}{$\begin{array}{l}15.3 \\
\text { Who is exempted } \\
\text { from paying these } \\
\text { fees? }\end{array}$} \\
\hline & & Yes & No & \\
\hline 1) ANC consultation & $\$$ & 1 & 2 & \\
\hline 2) FP counseling & $\$$ & 1 & 2 & \\
\hline 3) Combined oral contraceptives & $\$$ & 1 & 2 & \\
\hline 4) Minipills (progestin only pills) & $\$$ & 1 & 2 & \\
\hline 5) Emergency contraceptive pills & $\$$ & 1 & 2 & \\
\hline $\begin{array}{l}\text { 6) Progestin-only injectables (injection } \\
\text { every } 2 \text { or } 3 \text { months) }\end{array}$ & $\$$ & 1 & 2 & \\
\hline 7) Monthly injectables & $\$$ & 1 & 2 & \\
\hline 8) Combined patches & $\$$ & 1 & 2 & \\
\hline 9) Combined vaginal rings & $\$$ & 1 & 2 & \\
\hline 10) Jadelle implants & $\$$ & 1 & 2 & \\
\hline 11) Implanon implants & $\$$ & 1 & 2 & \\
\hline 12) Sinoplant (II) implants & $\$$ & 1 & 2 & \\
\hline 13) IUD & $\$$ & 1 & 2 & \\
\hline 14) IUS & $\$$ & 1 & 2 & \\
\hline 15) Male condoms & $\$$ & 1 & 2 & \\
\hline 16) Female condoms & $\$$ & 1 & 2 & \\
\hline 17) Diaphragms & $\$$ & 1 & 2 & \\
\hline 18) Spermicides & $\$$ & 1 & 2 & \\
\hline 19) Cervical caps & $\$$ & 1 & 2 & \\
\hline 20) Female sterilization & $\$$ & 1 & 2 & \\
\hline 21) Vasectomy & $\$$ & 1 & 2 & \\
\hline 22) HIV/AIDS testing & $\$$ & 1 & 2 & \\
\hline 23) Syphilis testing & $\$$ & 1 & 2 & \\
\hline 24) Other STIs testing & $\$$ & 1 & 2 & \\
\hline
\end{tabular}




\section{B. Observation guide}

\section{INSTRUCTIONS TO DATA}

COLLECTOR: Before proceeding to observe the interaction between client and provider, use the greeting below to explain to the provider that you will be observing him/her while he attends to his/her clients, to make sure that she/he knows that you are not there to evaluate her/him and that you are not an "expert" who can be consulted during the session. Then obtain the client's informed consent. When observing, be as discreet as possible. Try to sit so that you are behind the client but not directly in view of the provider, and make notes quickly. For each question, describe or circle the code of the response that most appropriately represents your observation of what happened during the interaction. As discussed during the training, you may witness behavior that poses a serious risk to the client's health. Please keep in mind the guidelines for when to intervene in the consultation on behalf of the client's welfare.

\section{GREETING FOR THE PROVIDER: My} name is and I work with , where we are conducting a study

to see what information clients are given during their antenatal care visits. This information will help us to propose ways in which to improve the services offered. As a part of this study, we are observing the interaction of health providers and their clients during antenatal care visits. I will observe silently as you attend to your clients and take notes. I am in no way an expert in your area, and I am not here to evaluate your work. I will not make any comments or interfere in your consultations.

Your participation in this component of the study will remain confidential. I will not record your name in the notes I take. This way, no one will be able to know that I observed your appointments. Do I have your permission?
INFORMED CONSENT FORM FOR THE CLIENT: My name is

and I work with , where we are conducting a study to see what information clients are given during their antenatal care visits. This information will help us to propose ways in which to improve the services offered. As a part of this study, we are observing the interaction of health providers and their clients during antenatal care visits. I would appreciate it if you allowed me to observe your appointment today. If you do, I will be accompanying you through your visit and seeing what you and your provider talk about. I will also observe when he examines you. I am not a health provider in this facility and will not make any comments or participate in your consultations in any way. At the end of your visit, I will, if you allow me to, ask you some questions regarding your experience during your visit. This interview will be private, and none of the providers that see you today will be present.

However, your participation in this study is voluntary, and you can choose not to let me accompany you or to answer my questions. If you choose not to participate in either component of the study, you will not be penalized in any way. If you agree to participate and you change your mind later, you can also ask me to stop observing and exit the room whenever you want.

If you participate, you will not receive money or gifts, and you will not benefit directly from your participation. However, your participation will result in improved future maternal and reproductive health services. Your participation in this study will remain confidential. I will not record your name in the notes I take. This way, no one will be able to know that I observed your services.

Finally, if you have any questions about this study at a later stage, you can come back here and clear your doubts with your provider at the clinic. Do you agree to participate in this study? 
1. Facility identification

\begin{tabular}{|c|c|c|c|}
\hline No. & QUESTIONS & CODING CATEGORIES & \\
\hline 1.1 & Date of observations & $\overline{\text { (Day / Month/ Year) }}$ & \\
\hline 1.2 & Facility name & & \\
\hline 1.3 & City or locality & & \\
\hline 1.4 & Type of facility & Hospital & 1 \\
\hline & & Health center with maternity ward & 2 \\
\hline & & Health center without maternity ward & 3 \\
\hline & & Health post with maternity ward & 4 \\
\hline & & Health post without maternity ward & 5 \\
\hline & & Dispensary & 6 \\
\hline & & Other: & 7 \\
\hline 1.5 & Type of sector & Government & 1 \\
\hline & & $\mathrm{NGO}$ & 2 \\
\hline & & \begin{tabular}{|l|} 
Private \\
\end{tabular} & 3 \\
\hline & & Other: & 4 \\
\hline 1.6 & Result of the observation & Complete & 1 \\
\hline & & Incomplete & 2 \\
\hline & & Refused & 3 \\
\hline & & Other: & 4 \\
\hline
\end{tabular}

\section{Integration of ANC and FP services}

No. QUESTIONS

Interviewer: Observe the client-provider interaction during the antenatal check-up visit and note whether providers do the following.

2.1 Ask whether client wants more children in the future.

2.2 Ask about previous FP use.

2.3 Ask whether client may want to use a method after delivery.

2.4 Ask for any FP method preference.

2.5 Explain different FP method options.

\begin{tabular}{|l|l|l|}
\hline 2.6 & Interviewer: Mark the FP & Minipills (progestin-only pills)
\end{tabular}

methods discussed.

Combined oral contraceptives

CODING CATEGORIES

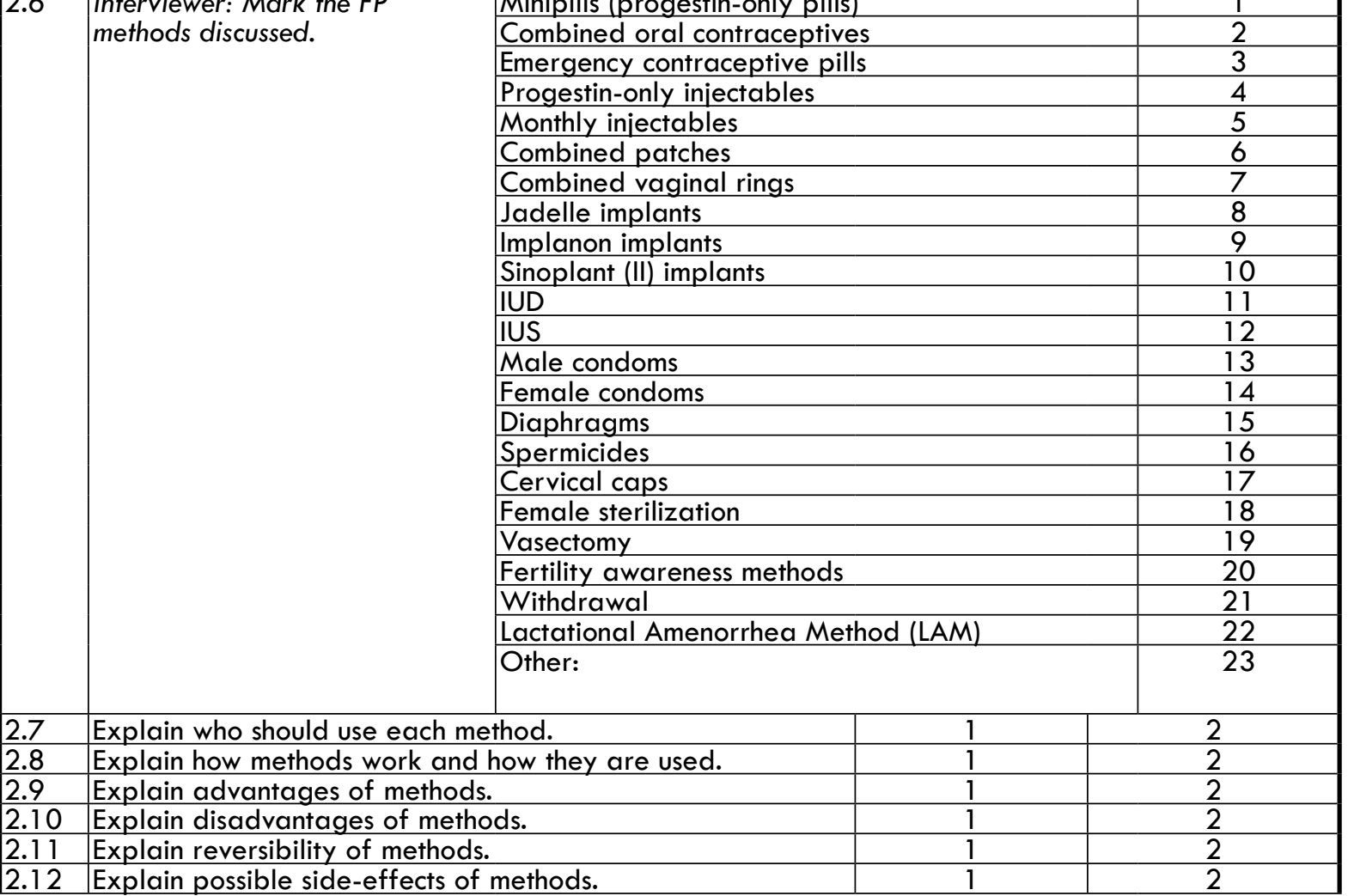




\begin{tabular}{|c|c|c|c|c|}
\hline 2.13 & Discuss client's fears and concern & is about methods. & 1 & 2 \\
\hline Expla & $n$ the following conditions of $\mathrm{L}$ & AM: & Yes & No \\
\hline 2.14 & Exclusive or almost exclusive bre & astfeeding & 1 & 2 \\
\hline 2.15 & Infant must be less than 6 month & & 1 & 2 \\
\hline 2.16 & Absence of menses since deliver & & 1 & 2 \\
\hline 2.17 & $\begin{array}{l}\text { Mention that a condom is the onl } \\
\text { against HIV/AIDS. }\end{array}$ & ly FP method that protects & 1 & 2 \\
\hline 2.18 & Explain where methods can be 0 & btained. & 1 & 2 \\
\hline 2.19 & Recommend the client to seek FP & counseling after delivery. & 1 & 2 \\
\hline 2.20 & $\begin{array}{l}\text { Interviewer: Did the woman expre } \\
\text { method after delivery? }\end{array}$ & ess interest in using an FP & 1 & 2 \\
\hline 2.21 & Interviewer: What methods did & Minipills (progestin-only $p$ & & 1 \\
\hline & the client express an interest in? & Combined oral contracep & & 2 \\
\hline & & Emergency contraceptive & & 3 \\
\hline & & Progestin-only injectables & & 4 \\
\hline & Interviewer: Mark all that apply. & Monthly injectables & & 5 \\
\hline & & Combined patches & & 6 \\
\hline & & Combined vaginal rings & & 7 \\
\hline & & Jadelle implants & & 8 \\
\hline & & Implanon implants & & 9 \\
\hline & & Sinoplant (II) implants & & 10 \\
\hline & & IUD & & 11 \\
\hline & & IUS & & 12 \\
\hline & & Male condoms & & 13 \\
\hline & & Female condoms & & 14 \\
\hline & & Diaphragms & & 15 \\
\hline & & Spermicides & & 16 \\
\hline & & Cervical caps & & 17 \\
\hline & & Female sterilization & & 18 \\
\hline & & Vasectomy & & 19 \\
\hline & & Fertility awareness metho & & 20 \\
\hline & & Withdrawal & & 21 \\
\hline & & LAM & & 22 \\
\hline & & Other: & & 23 \\
\hline
\end{tabular}

\section{Introduction and clinical history}

\begin{tabular}{|c|c|c|c|}
\hline \multirow{2}{*}{\multicolumn{2}{|c|}{\begin{tabular}{|l|l|} 
No. & QUESTIONS \\
Introduction
\end{tabular}}} & \multicolumn{2}{|c|}{ CODING CATEGORIES } \\
\hline & & Yes & No \\
\hline 3.1 & Greet client. & 1 & 2 \\
\hline 3.2 & Introduce yourself to the client. & 1 & 2 \\
\hline 3.3 & $\begin{array}{l}\text { Tell the client what is going to be done and encourage her to } \\
\text { ask questions. }\end{array}$ & 1 & 2 \\
\hline \multicolumn{2}{|r|}{ Clinical history } & Yes & No \\
\hline 3.4 & Ask age of client. & 1 & 2 \\
\hline 3.5 & Ask or help calculate gestational age. & 1 & 2 \\
\hline 3.6 & Ask history of hypertension. & 1 & 2 \\
\hline 3.7 & Ask history of diabetes. & 1 & 2 \\
\hline 3.8 & Ask about alcohol use and smoking. & 1 & 2 \\
\hline 3.9 & Ask about HIV status. & 1 & 2 \\
\hline 3.10 & Ask about TB history. & 1 & 2 \\
\hline 3.11 & Ask about general health problems. & 1 & 2 \\
\hline 3.12 & Ask about medication currently taken. & 1 & 2 \\
\hline \multicolumn{2}{|c|}{ History of previous pregnancies } & Yes & No \\
\hline 3.13 & Ask number of prior pregnancies and births. & 1 & 2 \\
\hline 3.14 & Ask whether client had any infant who died in the first week. & 1 & 2 \\
\hline 3.15 & $\begin{array}{l}\text { Ask whether client had heavy bleeding during or after } \\
\text { delivery with a previous pregnancy. }\end{array}$ & 1 & 2 \\
\hline 3.16 & Ask whether client had previous assisted delivery. & 1 & 2 \\
\hline \multicolumn{2}{|r|}{ Danger signs in pregnancy } & Yes & No \\
\hline 3.17 & Ask about any bleeding during this pregnancy. & 1 & 2 \\
\hline 3.18 & $\begin{array}{l}\text { Ask about any vaginal discharge observed during this } \\
\text { pregnancy. }\end{array}$ & 1 & 2 \\
\hline 3.19 & Ask whether client felt the baby move (late in pregnancy). & 1 & 2 \\
\hline 3.20 & $\begin{array}{l}\text { Ask whether client had any other symptoms or problems that } \\
\text { she thinks might be related to this pregnancy. }\end{array}$ & 1 & 2 \\
\hline
\end{tabular}




\begin{tabular}{|c|c|c|c|}
\hline \multicolumn{2}{|c|}{ Screening for TB } & \multirow{2}{*}{$\begin{array}{ll}\text { Yes } & \\
& 1\end{array}$} & \multirow{2}{*}{ No } \\
\hline 3.21 & $\begin{array}{l}\text { Ask about persistent cough for three or more weeks with or } \\
\text { without blood-stained sputum. }\end{array}$ & & \\
\hline 3.22 & Ask about chest pain. & 1 & 2 \\
\hline 3.23 & Ask about close contact with someone with TB. & 1 & 2 \\
\hline 3.24 & Ask for loss of body weight in past month. & 1 & 2 \\
\hline 3.25 & Ask about intermittent fever for more than 2 weeks. & 1 & 2 \\
\hline 3.26 & Ask about night sweats for more than 2 weeks. & 1 & 2 \\
\hline 3.27 & Ask whether client ever had BGG immunization. & 1 & 2 \\
\hline 3.28 & Explore signs and symptoms of other opportunistic infections. & 1 & 2 \\
\hline
\end{tabular}

4. Physical exam

\begin{tabular}{|c|c|c|c|}
\hline \multirow{2}{*}{\multicolumn{2}{|c|}{\begin{tabular}{|l|l|} 
No. & QUESTIONS \\
\end{tabular}}} & \multicolumn{2}{|l|}{ CODING CATEGORIES } \\
\hline & & Yes & No \\
\hline 4.1 & Wash hands before examining client. & $\begin{array}{l}\text { a. Yes, with water only } \\
\text { b. Yes, water and soap } \\
\text { c. Yes, with antiseptic } \\
\text { d. Other: }\end{array}$ & 2 \\
\hline 4.2 & Take weight. & 1 & 2 \\
\hline 4.3 & Check height. & 1 & 2 \\
\hline 4.4 & Take blood pressure. & 1 & 2 \\
\hline 4.5 & Take temperature. & 1 & 2 \\
\hline 4.6 & Examine hands and eyes for pallor. & 1 & 2 \\
\hline 4.7 & Conduct breast exam. & 1 & 2 \\
\hline 4.8 & Check fetal movements. & 1 & 2 \\
\hline 4.9 & Listen to fetal heart sounds. & 1 & 2 \\
\hline 4.10 & Conduct pelvic examination. & 1 & 2 \\
\hline \multicolumn{4}{|c|}{$\begin{array}{l}\text { Interviewer: If pelvic examination was performed, did the } \\
\text { provider: }\end{array}$} \\
\hline 4.11 & Wash her hands before the exam? & $\begin{array}{l}\text { a. Yes, with water only } \\
\text { b. Yes, water and soap } \\
\text { c. Yes, with antiseptic } \\
\text { d. Other: }\end{array}$ & 2 \\
\hline 4.12 & Put on new or disinfected gloves before the exam? & 1 & 2 \\
\hline 4.13 & Use sterilized or disinfected instruments? & 1 & 2 \\
\hline
\end{tabular}

\section{Drugs and immunizations}

\begin{tabular}{|c|c|c|c|}
\hline No. & QUESTIONS & CODING CA & \\
\hline Iron & nd folic acid & Yes & No \\
\hline 5.1 & Prescribe/give iron/folic acid. & $\begin{array}{l}\text { a. Prescribe } \\
\text { b. Give }\end{array}$ & 2 \\
\hline 5.2 & Explain purpose of iron tables. & 1 & 2 \\
\hline 5.3 & Explain how to take iron tables. & 1 & 2 \\
\hline Teta & s toxoid & Yes & No \\
\hline 5.4 & $\begin{array}{l}\text { Assess need (ask how many injections has the client } \\
\text { had). }\end{array}$ & 1 & 2 \\
\hline 5.5 & Prescribe/give tetanus toxoid. & $\begin{array}{l}\text { a. Prescribe } \\
\text { b. Give }\end{array}$ & 2 \\
\hline 5.6 & Explain purpose of tetanus toxoid. & 1 & 2 \\
\hline
\end{tabular}


6. Information on pregnancy and delivery

\begin{tabular}{|c|c|c|c|}
\hline No. & QUESTIONS & CODING & RIES \\
\hline Self-c & & Yes & No \\
\hline 6.1 & Assess nutritional status using Body Mass Index. & 1 & 2 \\
\hline 6.2 & $\begin{array}{l}\text { Advise about quantity and quality of food to eat during } \\
\text { pregnancy. }\end{array}$ & 1 & 2 \\
\hline 6.3 & Discuss personal hygiene. & 1 & 2 \\
\hline 6.4 & Advise on rest and exercise. & 1 & 2 \\
\hline 6.5 & Give date for next ANC visit. & 1 & 2 \\
\hline Dang & r signs & Yes & No \\
\hline Interv & ewer: Explain that women should return to the facility if they $\mathrm{e}$ & erienced the & ng. \\
\hline 6.6 & Vaginal bleeding & 1 & 2 \\
\hline 6.7 & Fever (feeling hot) & 1 & 2 \\
\hline 6.8 & Excessive tiredness and breathlessness & 1 & 2 \\
\hline 6.9 & Swelling in the face, hands, legs & 1 & 2 \\
\hline 6.10 & Severe headache or blurred vision & 1 & 2 \\
\hline 6.11 & Sudden gush of water in the vagina & 1 & 2 \\
\hline 6.12 & Labored breathing & 1 & 2 \\
\hline 6.12 & Premature labor pains & 1 & 2 \\
\hline 6.13 & Baby moving less or not moving at all & 1 & 2 \\
\hline Deliv & & Yes & No \\
\hline 6.14 & Remind client of expected date of delivery. & 1 & 2 \\
\hline 6.15 & $\begin{array}{l}\text { Suggest that client have a qualified birth attendant/deliver } \\
\text { at health facility. }\end{array}$ & 1 & 2 \\
\hline 6.16 & Suggest that client deliver at health facility. & 1 & 2 \\
\hline 6.17 & Explain symptoms/signs of labor. & 1 & 2 \\
\hline 6.18 & Discuss items to have at hand for delivery. & 1 & 2 \\
\hline 6.19 & Explain danger sians in delivery. & 1 & $\frac{2}{2}$ \\
\hline
\end{tabular}

\section{HIV/AIDS and STIs}

\begin{tabular}{|l|l|l|l|}
\hline No. & QUESTIONS & \multicolumn{1}{l|}{ CODING CATEGORIES } \\
\hline Interviewer: Mark whether the provider discusses the following. & Yes & No \\
\hline 7.1 & Discuss STIs symptoms/signs. & 1 & 2 \\
\hline 7.2 & Discuss effects of STI/HIV/AIDS in pregnancy. & 1 \\
\hline 7.3 & Inquire/ask client about presence of STI/HIV symptoms. & 1 & 2 \\
\hline \multirow{7}{*}{7.4} & Discuss STI/HIV risk factors: & Yes & No \\
\cline { 2 - 4 } & Unprotected sex (no condom use) & 1 & 2 \\
\cline { 2 - 4 } & Multiple sex partners & 1 & 2 \\
\cline { 2 - 4 } & Partner with multiple sex partners & 1 & 2 \\
\cline { 2 - 4 } & Intravenous drug use & 1 & 2 \\
\hline 7.5 & Explain that condoms reduce HIV risk. & 1 & 2 \\
\hline 7.6 & Explain that abstinence reduces HIV risk. & 1 & 2 \\
\hline 7.7 & Explain how to use condoms. & 1 & 2 \\
\hline 7.8 & Ask client about their STI/HIV risk factors. & 1 & 2 \\
\hline 7.9 & Provide information on PMTCT of HIV. & 1 & 2 \\
\hline 7.10 & Discuss HIV testing. & 1 & 2 \\
\hline 7.11 & Discuss where to go for VCT services. & 1 & 2 \\
\hline 7.12 & Discuss client's interest in getting tested. & 1 & 2 \\
\hline 7.13 & Suggest partner gets tested for HIV. & & 2 \\
\hline
\end{tabular}

\section{Counseling for HIV-positive women}

\begin{tabular}{|c|c|c|c|}
\hline \multirow{2}{*}{\multicolumn{2}{|c|}{$\begin{array}{l}\text { No. } Q \text { QUESTIONS } \\
\text { Interviewer: Mark whether the provider asks the following. }\end{array}$}} & \multicolumn{2}{|c|}{ CODING CATEGORIES } \\
\hline & & Yes & No \\
\hline 8.1 & Client received ARVs after last delivery. & 1 & 2 \\
\hline 8.2 & Client is currently taking ARVs. & 1 & 2 \\
\hline 8.3 & Client had a blood test for CD4 recently. & 1 & 2 \\
\hline 8.4 & Client has a good appetite. & 1 & 2 \\
\hline 8.5 & Client is experiencing any diarrhea or nausea. & 1 & 2 \\
\hline 8.6 & Client has lost excess weight. & 1 & 2 \\
\hline 8.7 & Partner's HIV status is established. & 1 & 2 \\
\hline Intel & wer: Mark whether the provider did any of the following. & Yes & No \\
\hline 8.8 & Inform about care and support available. & 1 & 2 \\
\hline 8.9 & Discuss symptoms of opportunistic infections. & 1 & 2 \\
\hline
\end{tabular}




\begin{tabular}{|l|l|c|c|}
\hline 8.10 & $\begin{array}{l}\text { Explain infant feeding Accessible, Feasible, Affordable, Safe } \\
\text { \& Sustainable (AFASS). }\end{array}$ & 1 & 2 \\
\hline 8.11 & $\begin{array}{l}\text { Explain where she and/or her partner can get psychosocial } \\
\text { support. }\end{array}$ & 1 & 2 \\
\hline 8.12 & $\begin{array}{l}\text { Advise against unprotected early penetrative sex after } \\
\text { delivery. }\end{array}$ & 2 \\
\hline
\end{tabular}

\section{Laboratory tests}

\begin{tabular}{ll|l}
\hline No. QUESTIONS & CODING CATEGORIES \\
\hline
\end{tabular}

Interviewer: Observe the client-providers interaction during the antenatal check-up visit, and check which of

the following tests were done on site, for which tests she was referred somewhere else, and which tests were not done at all.

\begin{tabular}{|c|c|c|c|c|}
\hline & Test & Done on site & Referred & Not done \\
\hline 9.1 & Urine test & 1 & 2 & 3 \\
\hline 9.2 & Blood test for hemoglobin & 1 & 2 & 3 \\
\hline 9.3 & Blood grouping & 1 & 2 & 3 \\
\hline 9.4 & HIV test & 1 & 2 & 3 \\
\hline 9.5 & VDRL or RPR for syphilis & 1 & 2 & 3 \\
\hline \multirow[t]{2}{*}{9.6} & TB test & 1 & 2 & 3 \\
\hline & & & Yes & No \\
\hline 9.7 & \multicolumn{2}{|c|}{$\begin{array}{l}\text { Did the health provider explain clearly what tests were } \\
\text { going to be performed? }\end{array}$} & 1 & 2 \\
\hline 9.8 & \multicolumn{2}{|c|}{$\begin{array}{l}\text { If HIV test was done, did the client give her informed } \\
\text { consent? }\end{array}$} & 1 & 2 \\
\hline
\end{tabular}

\section{Post-test information on HIV/AIDS}

\section{\begin{tabular}{|l|l|}
\hline No. & QUESTIONS \\
\hline
\end{tabular}}

Interviewer: Observe the client-provider interaction during the antenatal check-up visit, once the client has taken the HIV test (if she does), and ask the following questions.

\begin{tabular}{|l|l|l|l|}
\hline 10.1 & $\begin{array}{l}\text { Did the woman receive her HIV/AIDS results in } \\
\text { private, or were there other people with her? } \\
\text { If there were other people, who were they? }\end{array}$ & $\begin{array}{l}\text { Received results alone. } \\
\text { There were other pregnant women } \\
\text { with her. }\end{array}$ & 1 \\
\cline { 2 - 4 } & \multicolumn{1}{|c|}{$\begin{array}{l}\text { If there were other people with her, } \\
\text { who? }\end{array}$} & 2 \\
\hline 10.2 & $\begin{array}{l}\text { Did the health provider explain clearly the results of the test? } \\
\text { 10.3 }\end{array}$ & $\begin{array}{l}\text { Did the health provider ask the client whether she had any } \\
\text { questions about her results? }\end{array}$ & 1 \\
\hline 10.4 & $\begin{array}{l}\text { If the results of the HIV test were negative, did the health } \\
\text { provider explain to the client how to protect herself so she } \\
\text { remained negative? }\end{array}$ & 2 \\
\hline 10.5 & $\begin{array}{l}\text { If the results of the HIV test were positive, did the health } \\
\text { provider explain to the client what she should do to protect } \\
\text { herself and her baby from the infection? }\end{array}$ & 2 \\
\hline
\end{tabular}

\section{Client's demographic information}

Interviewer: If you were not able to obtain the following information during the observation, ask the client to provide the following information once her consultation is over.
11.1 Age
11.2 Gestational age
11.3 Number of ANC visits, including this one 


\section{Client exit interview}

\section{INSTRUCTIONS FOR THE}

INTERVIEWERS: Approach all women as they leave the area where antenatal care services are provided, and ask them whether they are willing to be asked some questions about the services they received today. If they accept, make sure that you are in a place that guarantees privacy and where the woman is comfortable. Ask them for their informed consent to be interviewed (read the form below). Interview only women who give their informed consent. For each item in the interview, circle the code of the appropriate response or describe, as appropriate.

\section{INFORMED CONSENT FORM FOR} THE CLIENT: My name is

and I work with , where we are conducting a study to see what information clients are given during their antenatal care visits. This information will help us to propose ways in which to improve the services offered. As a part of this study, we are interviewing women who had an antenatal care visit today. In these interviews, we ask them about the services and information they obtained, their satisfaction with the services received, their plans for having more children in the future, and other health needs they may have. I would appreciate it if you allowed me to ask you some questions. The interview will be private, and none of the providers that saw you today will be present.

However, your participation in this study is voluntary, and you can choose not to let me interview you. If you choose not to participate in our study, you will not be penalized in any way. If you accept to participate and you change your opinion later, you can also ask me to interrupt the interview whenever you want.

If you participate, you will not receive money or gifts, and you will not benefit directly from your participation. However, your participation will result in improved future maternal and reproductive health services.

Your participation in this study will remain confidential. I will not record your name in the questionnaire. This way, no one will be able to know that I observed your appointments.

Finally, if you have any questions about this study at a later stage, you can come back here and clear your doubts with your provider at the clinic. Do you accept to participate in this study? 


\section{Facility identification}

\begin{tabular}{|c|c|c|c|}
\hline No. & QUESTIONS & \multicolumn{2}{|l|}{ CODING CATEGORIES } \\
\hline 1.1 & Date of interview & \multicolumn{2}{|l|}{ (Day/ Month/ Year) } \\
\hline 1.2 & Facility name & & \\
\hline 1.3 & City or locality & & \\
\hline 1.4 & Type of facility & Hospital & 1 \\
\hline & & Health center with maternity ward & 2 \\
\hline & & Health center without maternity ward & 3 \\
\hline & & Health post with maternity ward & 4 \\
\hline & & Health post without maternity ward & 5 \\
\hline & & Dispensary & 6 \\
\hline & & Other: & 7 \\
\hline 1.5 & Type of sector & Government & 1 \\
\hline & & NGO & 2 \\
\hline & & Private & 3 \\
\hline & & Other: & 4 \\
\hline 1.6 & Result of the interview & Complete & 1 \\
\hline & & Incomplete & 2 \\
\hline & & Refused & 3 \\
\hline & & Other: & 4 \\
\hline
\end{tabular}

\section{Reproductive history}

No. QUESTIONS

CODING CATEGORIES

GO TO

Interviewer: Explain that you are now going to ask some questions about the children she already has and her plans to have more children in the future.

\begin{tabular}{|c|c|c|c|c|}
\hline 2.1 & How many living children of your own do you have? & Living children: & \multicolumn{2}{|r|}{$\begin{array}{l}\text { if } 0 \\
-2.5\end{array}$} \\
\hline \multirow[t]{2}{*}{2.2} & \multirow[t]{2}{*}{ For how long have you been pregnant? } & Number of months: & & \\
\hline & & Number of weeks: & & \\
\hline \multirow[t]{4}{*}{2.3} & \multirow[t]{4}{*}{ In the future, would you like to have more children? } & Yes & 1 & \\
\hline & & No & 2 & $\begin{array}{l}\text { next } \\
\text { section }\end{array}$ \\
\hline & & Other: & 3 & \\
\hline & & Don't know & 98 & \\
\hline \multirow[t]{3}{*}{2.4} & \multirow{3}{*}{$\begin{array}{l}\text { How long would you like to wait before becoming } \\
\text { pregnant again? }\end{array}$} & Number of months: & & \\
\hline & & Number of years: & & \\
\hline & & Other: & & \\
\hline
\end{tabular}

\section{FP and optimal birth spacing}

\begin{tabular}{|l|l}
\hline No. & QUESTIONS \\
\hline
\end{tabular}

Interviewer: Explain that you are now going to discuss the FP information given during this visit and her plans to use an FP method.

\begin{tabular}{|c|c|c|c|c|}
\hline \multirow[t]{2}{*}{3.1} & \multirow{2}{*}{$\begin{array}{l}\text { During this ANC visit, did you receive any } \\
\text { written materials about FP? }\end{array}$} & Yes & 1 & \\
\hline & & No & 2 & \\
\hline \multirow[t]{2}{*}{3.2} & \multirow{2}{*}{$\begin{array}{l}\text { During this visit, did any health provider tell } \\
\text { you how soon after delivery a woman can get } \\
\text { pregnant? }\end{array}$} & Yes & 1 & \\
\hline & & No & 2 & > 3.4 \\
\hline
\end{tabular}




\begin{tabular}{|c|c|c|c|c|c|}
\hline \multirow[t]{7}{*}{3.3} & \multirow{7}{*}{$\begin{array}{l}\text { According to what they told you, how soon } \\
\text { after delivery can a woman get pregnant } \\
\text { again? }\end{array}$} & \multicolumn{2}{|c|}{$\begin{array}{l}\text { Whenever she restarts her sexual } \\
\text { relations }\end{array}$} & 1 & \\
\hline & & \multicolumn{2}{|c|}{ After her period returns } & 2 & \\
\hline & & \multicolumn{2}{|c|}{\begin{tabular}{|l|} 
After she stops breastfeeding \\
exclusively
\end{tabular}} & 3 & \\
\hline & & \multirow{2}{*}{\multicolumn{2}{|c|}{$\begin{array}{l}\text { After she stops breastfeeding } \\
\text { altogether } \\
\text { After } 6 \text { months }\end{array}$}} & 4 & \\
\hline & & & & 5 & \\
\hline & & \multicolumn{2}{|c|}{ Other: } & 6 & \\
\hline & & \multicolumn{2}{|l|}{ Don't know } & 98 & \\
\hline \multirow[t]{2}{*}{3.4} & \multirow{2}{*}{$\begin{array}{l}\text { During this visit, did any health provider talk } \\
\text { to you about the importance of waiting before } \\
\text { getting pregnant again? }\end{array}$} & \multicolumn{2}{|l|}{ Yes } & 1 & \\
\hline & & \multicolumn{2}{|l|}{ No } & 2 & 3.6 \\
\hline \multirow[t]{4}{*}{3.5} & \multirow{4}{*}{$\begin{array}{l}\text { After delivery, what is the ideal amount of } \\
\text { time that a woman should wait before getting } \\
\text { pregnant again? }\end{array}$} & \multicolumn{2}{|l|}{ Months: } & & \\
\hline & & \multirow{2}{*}{\multicolumn{2}{|c|}{\begin{tabular}{|l|} 
Years: \\
Other:
\end{tabular}}} & & \\
\hline & & & & & \\
\hline & & \multicolumn{2}{|l|}{ Don't know } & 98 & \\
\hline \multirow[t]{2}{*}{3.6} & \multirow{2}{*}{$\begin{array}{l}\text { During this visit, did a health provider talk to } \\
\text { you about the methods a couple may use to } \\
\text { avoid or delay pregnancy? }\end{array}$} & \multicolumn{2}{|l|}{ Yes } & 1 & \\
\hline & & No & & 2 & 3.8 \\
\hline 3.7 & Which methods were discussed with you? & Minipills (pr & stin-only pills) & 1 & \\
\hline & & Combined & contraceptives & 2 & \\
\hline & & Emergency & raceptive pills & 3 & \\
\hline & Interviewer: Mark all that apply. & Progestin-ol & jectables & 4 & \\
\hline & & Monthly inje & les & 5 & \\
\hline & & Combined $\mathrm{p}$ & nes & 6 & \\
\hline & & Combined & al rings & 7 & \\
\hline & & Jadelle imp & & 8 & \\
\hline & & Implanon im & & 9 & \\
\hline & & Sinoplant (II & olants & 10 & \\
\hline & & IUD & & 11 & \\
\hline & & IUS & & 12 & \\
\hline & & Male condo & & 13 & \\
\hline & & Female con & & 14 & \\
\hline & & Diaphragm & & 15 & \\
\hline & & Spermicide & & 16 & \\
\hline & & Cervical ca & & 17 & \\
\hline & & Female ster & tion & 18 & \\
\hline & & Vasectomy & & 19 & \\
\hline & & Fertility aw & ess methods & 20 & \\
\hline & & Withdrawa & & 21 & \\
\hline & & LAM & & 22 & \\
\hline & & Other: & & 23 & \\
\hline & & Don't know & & 98 & \\
\hline 3.8 & During this visit, did a health provider tell you & Yes & & 1 & \\
\hline & where you can obtain an FP method? & No & & 2 & 3.10 \\
\hline 3.9 & $\begin{array}{l}\text { Where did they tell you could obtain an FP } \\
\text { method? }\end{array}$ & & & & \\
\hline 3.10 & During this visit, did a health provider talk to & Yes & & 1 & \\
\hline & $\begin{array}{l}\text { you about LAM or the method of feeding your } \\
\text { baby only with breast milk? }\end{array}$ & No & & 2 & 3.12 \\
\hline 3.11 & $\begin{array}{l}\text { According to what you know, what are the three } \\
\text { or the method of feeding the baby only with br }\end{array}$ & $\begin{array}{l}\text { conditions t } \\
\text { east milk? }\end{array}$ & nust be fulfilled in & order & to use LAM \\
\hline & $\begin{array}{l}\text { Interviewer: Record spontaneous responses, then } \\
\text { ask about remaining items. }\end{array}$ & Not aided & Aided & Don' & know \\
\hline & $\begin{array}{l}\text { Feed the baby exclusively or almost exclusively } \\
\text { with breast milk. }\end{array}$ & 1 & 2 & & 98 \\
\hline & Baby must be less than 6 months old. & 1 & 2 & & 98 \\
\hline & $\begin{array}{l}\text { Monthly bleedings have not resumed since } \\
\text { delivery. }\end{array}$ & 1 & 2 & & 98 \\
\hline 3.12 & Are you planning to use a contraceptive or FP & Yes & & 1 & \\
\hline & method after the birth of your baby? & No & & 2 & $\begin{array}{l}\text { next } \\
\text { section }\end{array}$ \\
\hline
\end{tabular}




\begin{tabular}{|c|c|c|c|}
\hline \multirow[t]{14}{*}{3.13} & \multirow[t]{14}{*}{ Which method would you like to use? } & Minipills (pills of only progestine) & 1 \\
\hline & & Combined contraceptive pill & 2 \\
\hline & & Female voluntary sterilization & 3 \\
\hline & & Male sterilization (vasectomy) & 4 \\
\hline & & IUD & 5 \\
\hline & & Condom (male or female) & 6 \\
\hline & & Injectables & 7 \\
\hline & & Jadelle implants & 8 \\
\hline & & Implanon implants & 9 \\
\hline & & Sinoplant (II) implants & 10 \\
\hline & & LAM & 11 \\
\hline & & Other natural methods: & 12 \\
\hline & & Other: & 13 \\
\hline & & Don't know & 98 \\
\hline \multirow[t]{7}{*}{3.14} & \multirow{7}{*}{$\begin{array}{l}\text { How soon after delivery are you planning to } \\
\text { start using an FP method? }\end{array}$} & Immediately & 1 \\
\hline & & When she stops breastfeeding & 2 \\
\hline & & When her menstruation resumes & 3 \\
\hline & & After 6 weeks & 4 \\
\hline & & In _ months & 5 \\
\hline & & Other: & 6 \\
\hline & & Don't know & 98 \\
\hline \multirow[t]{7}{*}{3.15} & \multirow[t]{7}{*}{ Where will you go to obtain an FP method? } & This clinic & 1 \\
\hline & & Other clinic & 2 \\
\hline & & Pharmacy & 3 \\
\hline & & Community worker & 4 \\
\hline & & Facility where she delivers & 5 \\
\hline & & Other: & 6 \\
\hline & & Don't know & 98 \\
\hline
\end{tabular}

4. Access to ANC

No. QQUESTIONS

CODING CATEGORIES

Interviewer: Explain that you will now ask a few questions about the ANC she has received.

4.1 Approximately how long had you been pregnant when you received your first antenatal checkup?

4.2 For how long have you been pregnant?

4.3 During this pregnancy, how many times have you come to this or other clinics for antenatal services?

\begin{tabular}{|l|c|}
\hline Months: & \\
\hline Don't know & 98 \\
\hline Weeks: & \\
\hline Months: & \\
\hline Number of visits: & \\
\hline Don't know & 98 \\
\hline
\end{tabular}

5. Information received at ANC (danger signs, care in pregnancy, and breastfeeding)

\begin{tabular}{|c|c|c|c|c|c|}
\hline \multirow{3}{*}{\begin{tabular}{|l|} 
No. \\
5.1
\end{tabular}} & QUESTIONS & \multicolumn{3}{|c|}{ CODING CATEGORIES } & GO TO \\
\hline & \multirow{2}{*}{$\begin{array}{l}\text { During this ANC visit, did a health provider talk to } \\
\text { you about danger signs in pregnancy that need } \\
\text { immediate medical care? }\end{array}$} & \multicolumn{3}{|c|}{ Yes } & \\
\hline & & \multicolumn{3}{|l|}{ No } & 5.3 \\
\hline \multirow[t]{12}{*}{5.2} & \multicolumn{4}{|c|}{$\begin{array}{l}\text { What are the danger signs for which they told you that you need immediate medical care } \\
\text { when you are pregnant? }\end{array}$} & \\
\hline & $\begin{array}{l}\text { Interviewer: Record spontaneous responses, then ask } \\
\text { about remaining items. }\end{array}$ & Not aided & Aided & Don't know & \\
\hline & 1) Vaginal bleeding & 1 & 2 & 98 & \\
\hline & 2) Fever & 1 & 2 & 98 & \\
\hline & 3) Excessive tiredness and breathlessness & 1 & 2 & 98 & \\
\hline & 4) Swelling in the face, hands, legs & 1 & 2 & 98 & \\
\hline & 5) Severe headache or blurred vision & 1 & 2 & 98 & \\
\hline & 6) Sudden gush of water in the vagina & 1 & 2 & 98 & \\
\hline & 7) Labored breathing & 1 & 2 & 98 & \\
\hline & 8) Premature labor pains & 1 & 2 & 98 & \\
\hline & 9) Baby moving less or not moving at all & 1 & 2 & 98 & \\
\hline & 10) Other: & 1 & 2 & 98 & \\
\hline
\end{tabular}




\begin{tabular}{|c|c|c|c|c|c|c|}
\hline \multirow[t]{2}{*}{5.3} & \multirow{2}{*}{$\begin{array}{l}\text { In pregnancy, women must have special care and } \\
\text { precautions. During this ANC visit, did a health } \\
\text { provider give you any information/advice for your } \\
\text { care? }\end{array}$} & \multicolumn{3}{|l|}{ Yes } & 1 & \multirow[b]{2}{*}{5.5} \\
\hline & & \multicolumn{3}{|l|}{ No } & 2 & \\
\hline \multirow[t]{10}{*}{5.4} & \multicolumn{5}{|c|}{ What special care and precautions did they tell you to have when you are pregnant? } & \\
\hline & $\begin{array}{l}\text { Interviewer: Record spontaneous responses, then ask } \\
\text { about remaining items. }\end{array}$ & Not aided & Aided & \multicolumn{2}{|c|}{ Don't know } & \\
\hline & 1) Don't smoke. & 1 & 2 & \multicolumn{2}{|l|}{98} & \\
\hline & 2) Don't drink alcohol. & 1 & 2 & \multicolumn{2}{|l|}{98} & \\
\hline & 3) Reduce your salt intake. & 1 & 2 & \multicolumn{2}{|l|}{98} & \\
\hline & 4) Take a shower every day. & 1 & 2 & \multicolumn{2}{|l|}{98} & \\
\hline & 5) Avoid exercising a lot or carrying heavy loads. & 1 & 2 & \multicolumn{2}{|l|}{98} & \\
\hline & 6) Rest as much as possible. & 1 & 2 & \multicolumn{2}{|l|}{98} & \\
\hline & 7) Keep your feet up while resting. & 1 & 2 & \multicolumn{2}{|l|}{98} & \\
\hline & $\begin{array}{l}\text { 8) Have money and transportation handy for } \\
\text { emergencies. }\end{array}$ & 1 & 2 & \multicolumn{2}{|l|}{98} & \\
\hline \multirow[t]{2}{*}{5.5} & \multirow{2}{*}{$\begin{array}{l}\text { During this ANC visit, did any health provider talk } \\
\text { to you about the importance of taking iron and } \\
\text { folic acid? }\end{array}$} & \multicolumn{3}{|l|}{ Yes } & 1 & \\
\hline & & \multicolumn{3}{|l|}{ No } & 2 & \\
\hline \multirow[t]{4}{*}{5.6} & \multirow[t]{4}{*}{ Are you taking iron and folic acid tablets? } & \multicolumn{3}{|c|}{ Yes, iron and folic acid } & 1 & 5.8 \\
\hline & & \multicolumn{3}{|c|}{ Yes, iron } & 2 & 5.8 \\
\hline & & \multicolumn{3}{|c|}{ Yes, folic acid } & 3 & 5.8 \\
\hline & & \multicolumn{3}{|l|}{ No } & 4 & \\
\hline 5.7 & Why are you not taking iron and folic acid tablets? & I didn't kno & I should & them. & 1 & \\
\hline & & I don't whe & to get $t$ & & 2 & \\
\hline & & I don't have & money to & them. & 3 & \\
\hline & & $\begin{array}{l}\text { I am afraid } \\
\text { baby. }\end{array}$ & hey may & m my & 4 & \\
\hline & & They aren't & xvailable & he clinic. & 5 & \\
\hline & & $\begin{array}{l}\text { My partner } \\
\text { a fiend ad } \\
\text { them. }\end{array}$ & $\begin{array}{l}\text { a family } \\
\text { sed me } n\end{array}$ & $\begin{array}{l}\text { nber, or } \\
\text { take }\end{array}$ & 6 & \\
\hline & & Other: & & & 7 & \\
\hline 5.9 & During this ANC visit, did a health provider talk to & Yes & & & 1 & \\
\hline & you about breastfeeding? & No & & & 2 & 5.11 \\
\hline 5.10 & What information/advice did you receive about hov & $w$ and when & o breast & your bak & oy? & \\
\hline & $\begin{array}{l}\text { Interviewer: Record spontaneous responses, then ask } \\
\text { about remaining items. }\end{array}$ & Not aided & Aided & Don't kn & ow & \\
\hline & 1) How to breastfeed the baby & 1 & 2 & 98 & & \\
\hline & 2) How to solve problems related to breastfeeding & 1 & 2 & 98 & & \\
\hline & $\begin{array}{l}\text { 3) Breastfeed the baby in the first } 2 \text { to } 3 \text { hours } \\
\text { after delivery }\end{array}$ & 1 & 2 & 98 & & \\
\hline & $\begin{array}{l}\text { 4) Breastfeed exclusively for the first } 6 \text { months } \\
\text { after delivery }\end{array}$ & 1 & 2 & 98 & & \\
\hline 5.11 & During this visit, did a health provider inform you & Yes & & & 1 & \\
\hline & about the expected date of delivery? & No & & & 2 & \\
\hline 5.12 & During this visit, did a health provider inform you & Yes & & & 1 & \\
\hline & about the return date for the next ANC visit? & No & & & 2 & \\
\hline & & Don't know & & & 98 & \\
\hline
\end{tabular}


6. Delivery plans

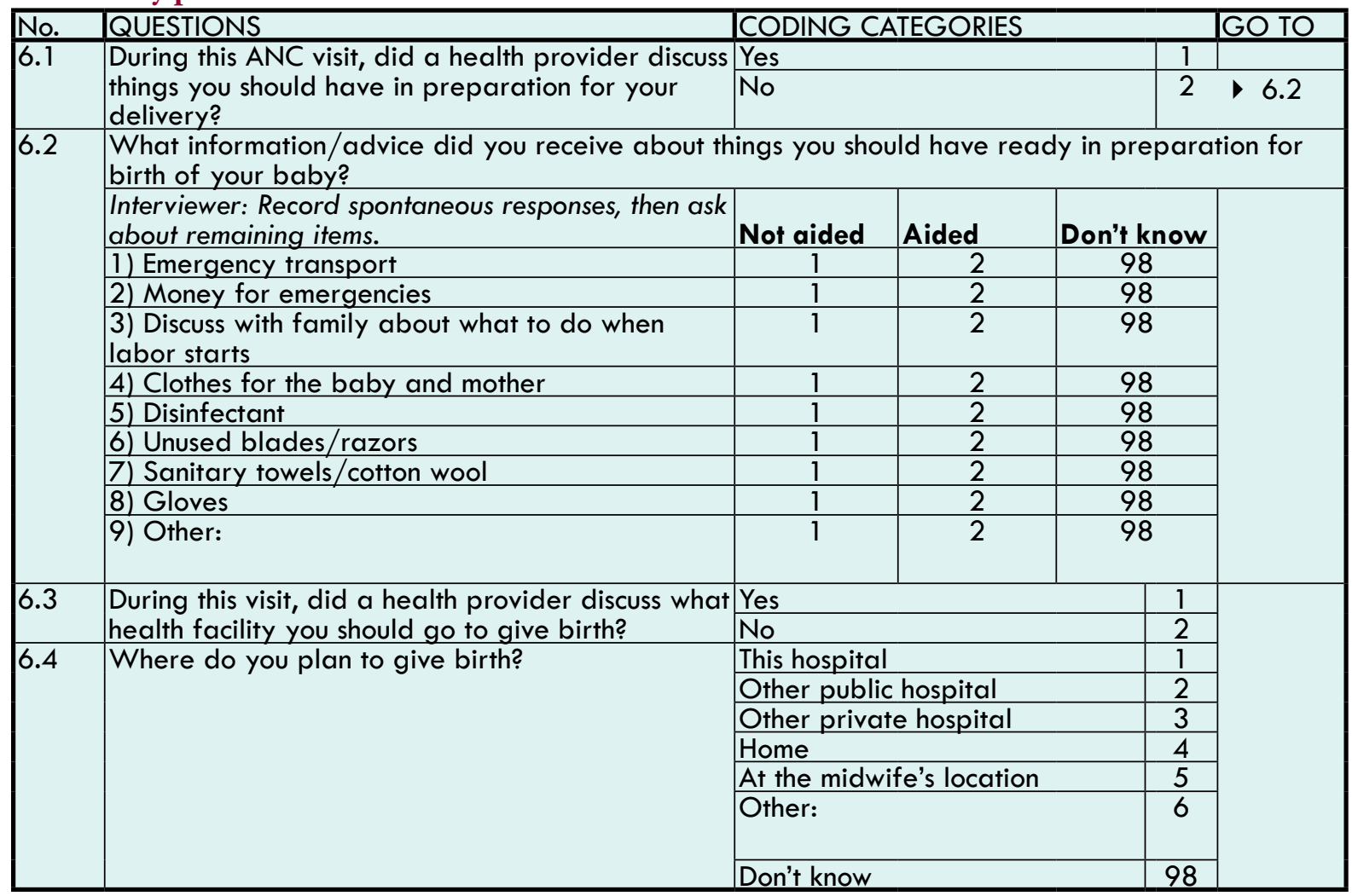

\section{PMTCT of HIV}

\begin{tabular}{|c|c|c|c|c|}
\hline \multirow{3}{*}{ No. } & QUESTIONS & CODING CATEGORIES & & GO TO \\
\hline & \multirow{2}{*}{$\begin{array}{l}\text { Have you ever heard of HIV or the } \\
\text { disease called AIDS? }\end{array}$} & Yes & 1 & \\
\hline & & No & 2 & $\begin{array}{l}\text { next } \\
\text { section }\end{array}$ \\
\hline \multirow[t]{7}{*}{7.2} & \multirow[t]{3}{*}{ Do you know how to prevent HIV? } & Use condoms & 1 & \\
\hline & & Fidelity to one partner & 2 & \\
\hline & & Encourage partner to remain faithful & 3 & \\
\hline & \multirow[t]{4}{*}{ Interviewer: Mark all that apply. } & Abstain from sex & 4 & \\
\hline & & Avoid sharing razors/needles & 5 & \\
\hline & & Other: & 6 & \\
\hline & & Don't know & 98 & \\
\hline \multirow[t]{2}{*}{7.3} & \multirow{2}{*}{$\begin{array}{l}\text { During this visit, did a health provider } \\
\text { talk to you about HIV or AIDS? }\end{array}$} & Yes & 1 & \\
\hline & & No & 2 & 7.5 \\
\hline
\end{tabular}




\begin{tabular}{|c|c|c|c|c|c|c|}
\hline \multirow[t]{13}{*}{7.4} & \multicolumn{5}{|l|}{ What did the provider tell you about HIV? } & \\
\hline & \multirow{2}{*}{\multicolumn{2}{|c|}{$\begin{array}{l}\text { Interviewer: Mark spontaneous responses, then ask } \\
\text { about remaining items. } \\
\text { 1) A woman with HIV can transmit it to her baby } \\
\text { without appropriate care. }\end{array}$}} & Not aided & Aided & Don't know & \\
\hline & & & 1 & 2 & 98 & \\
\hline & \multicolumn{2}{|c|}{$\begin{array}{l}\text { 2) A woman with HIV can transmit it to her baby if } \\
\text { she breastfeeds. }\end{array}$} & 1 & 2 & 98 & \\
\hline & \multirow{2}{*}{\multicolumn{2}{|c|}{$\begin{array}{l}\text { 3) Breastfeeding exclusively reduces the chance } \\
\text { that a woman with HIV will transmit it to her baby. } \\
\text { 4) There are medicines to help prevent a woman } \\
\text { with HIV from transmitting it to her baby. }\end{array}$}} & 1 & 2 & 98 & \\
\hline & & & 1 & 2 & 98 & \\
\hline & \multicolumn{2}{|c|}{ 5) Having multiple sex partners increases HIV risk. } & 1 & 2 & 98 & \\
\hline & \multicolumn{2}{|c|}{$\begin{array}{l}\text { 6) HIV risk is high if partner has multiple sex } \\
\text { partners. }\end{array}$} & 1 & 2 & 98 & \\
\hline & \multicolumn{2}{|l|}{ 7) Using condoms reduces HIV risk. } & 1 & 2 & 98 & \\
\hline & \multicolumn{2}{|l|}{ 8) Abstinence reduces HIV risk. } & 1 & 2 & 98 & \\
\hline & \multicolumn{2}{|c|}{ 9) A pregnant woman should have an HIV test. } & 1 & 2 & 98 & \\
\hline & \multicolumn{2}{|c|}{ 10) The partner should have an HIV test. } & 1 & 2 & 98 & \\
\hline & \multicolumn{2}{|l|}{ 11) Other: } & 1 & 2 & 98 & \\
\hline \multirow[t]{3}{*}{7.5} & \multirow{3}{*}{$\begin{array}{l}\text { In this visit, did a health provider offer } \\
\text { you to take the HIV test at this clinic or } \\
\text { refer you for HIV testing elsewhere? }\end{array}$} & \multicolumn{3}{|c|}{ Yes, take the test at the clinic } & 1 & \\
\hline & & \multicolumn{3}{|c|}{ Yes, be referred to a other clinic } & 2 & \\
\hline & & \multicolumn{3}{|c|}{ No } & 3 & \\
\hline \multirow[t]{4}{*}{7.6} & \multirow[t]{4}{*}{ Did you take the HIV test today? } & \multicolumn{3}{|l|}{ Yes } & 1 & 7.8 \\
\hline & & \multicolumn{3}{|l|}{ No } & 2 & \\
\hline & & \multicolumn{3}{|l|}{ Don't know } & 98 & \\
\hline & & \multicolumn{3}{|l|}{ No response } & 99 & \\
\hline \multirow[t]{2}{*}{7.7} & \multirow[t]{2}{*}{ Did you receive your HIV test result? } & \multicolumn{3}{|l|}{ Yes } & 1 & 7.9 \\
\hline & & \multicolumn{3}{|l|}{ No } & 2 & 7.11 \\
\hline \multirow[t]{4}{*}{7.8} & Have you taken the HIV test during this & Yes & & & 1 & \\
\hline & pregnancy? & No & & & 2 & 7.11 \\
\hline & & Don't know & & & 98 & 7.11 \\
\hline & & No respons & & & 99 & 7.11 \\
\hline 7.9 & Would you tell me your HIV test & HIV positive & & & 1 & \\
\hline & results? Please know that I will keep & HIV negativ & & & 2 & 7.11 \\
\hline & this information confidential. & Would not i & indicate stat & & 3 & 7.11 \\
\hline & & Don't know & & & 98 & 7.11 \\
\hline 7.10 & Have you received any drug to treat & Yes & & & 1 & \\
\hline & your HIV? & No & & & 2 & \\
\hline & & Don't know & & & 98 & \\
\hline 7.11 & Has your partner tested for HIV? & Yes & & & 1 & \\
\hline & & No & & & 2 & \\
\hline & & Don't know & & & 98 & \\
\hline
\end{tabular}

\section{PMTCT of STIs}

\begin{tabular}{|c|c|c|c|c|}
\hline No. & QUESTIONS & CODING CATEGORIES & & GO TO \\
\hline \multirow[t]{2}{*}{8.1} & \multirow{2}{*}{$\begin{array}{l}\text { Have you heard of diseases that men } \\
\text { and women can get through sexual } \\
\text { intercourse, sometimes called sexually } \\
\text { transmitted infections, or STls? }\end{array}$} & Yes & 1 & \\
\hline & & No & 2 & 8.4 \\
\hline \multirow[t]{11}{*}{8.2} & If a woman has an STI, what symptoms & No symptoms & 1 & \\
\hline & might she have? & Lower abdominal pain & 2 & \\
\hline & & Unusual or abnormal discharge & 3 & \\
\hline & \multirow{8}{*}{ Interviewer: Mark all that apply } & Burning pain on urination & 4 & \\
\hline & & Genital ulcers/sores & 5 & \\
\hline & & Swelling in groin area & 6 & \\
\hline & & Itching & 7 & \\
\hline & & Pain during intercourse & 8 & \\
\hline & & Genital warts & 9 & \\
\hline & & Other: & 10 & \\
\hline & & Don't know & 98 & \\
\hline
\end{tabular}




\begin{tabular}{|c|c|c|c|}
\hline \multirow[t]{11}{*}{8.3} & \multirow{3}{*}{$\begin{array}{l}\text { If a man has an STI, what symptoms } \\
\text { might he have? }\end{array}$} & No symptoms & 1 \\
\hline & & Lower abdominal pain & 2 \\
\hline & & Unusual or abnormal discharge & 3 \\
\hline & \multirow{8}{*}{ Interviewer: Mark all that apply. } & Burning pain on urination & 4 \\
\hline & & Genital ulcers/sores & 5 \\
\hline & & Swelling in groin area & 6 \\
\hline & & Itching & 7 \\
\hline & & Pain during intercourse & 8 \\
\hline & & Genital warts & 9 \\
\hline & & Other: & 10 \\
\hline & & Don't know & 98 \\
\hline \multirow[t]{2}{*}{8.4} & \multirow{2}{*}{$\begin{array}{l}\text { During this ANC visit, did a health } \\
\text { provider talk to you about STIs? }\end{array}$} & Yes & 1 \\
\hline & & No & 2 \\
\hline
\end{tabular}

\section{Malaria}

\begin{tabular}{|c|c|c|c|}
\hline No. & QUESTIONS & CODING CATEGORIES & \\
\hline \multirow[t]{2}{*}{9.1} & \multirow{2}{*}{$\begin{array}{l}\text { In this ANC visit, did a health provider talk to you about } \\
\text { why it is important to take antimalarial medicines during } \\
\text { pregnancy? }\end{array}$} & Yes & 1 \\
\hline & & No & 2 \\
\hline \multirow[t]{3}{*}{9.2} & \multirow{3}{*}{$\begin{array}{l}\text { In this visit, has a health provider given or prescribed } \\
\text { any antimalarial medicines for you? }\end{array}$} & Yes, given & 1 \\
\hline & & Yes, prescribed & 2 \\
\hline & & No & 3 \\
\hline \multirow[t]{2}{*}{9.3} & \multirow{2}{*}{$\begin{array}{l}\text { During this visit, did a provider advise you to use } \\
\text { treated bed nets/mosquito nets to prevent malaria? }\end{array}$} & Yes & 1 \\
\hline & & No & 2 \\
\hline \multirow[t]{2}{*}{9.4} & \multirow{2}{*}{$\begin{array}{l}\text { During this visit, did a provider ask you whether you had } \\
\text { ever received a tetanus toxoid injection? }\end{array}$} & Yes & 1 \\
\hline & & No & 2 \\
\hline
\end{tabular}

\section{IEC materials}

\begin{tabular}{|c|c|c|c|c|}
\hline No. & QUESTIONS & CODING CATEGORIES & & GO TO \\
\hline \multirow[t]{2}{*}{10.1} & \multirow{2}{*}{$\begin{array}{l}\text { Did you receive any information materials } \\
\text { during this ANC visit? }\end{array}$} & Yes & 1 & \\
\hline & & No & 2 & $\begin{array}{l}\text { next } \\
\text { section }\end{array}$ \\
\hline \multirow[t]{8}{*}{10.2} & \multirow{8}{*}{$\begin{array}{l}\text { What were they about? The content of the } \\
\text { information materials? }\end{array}$} & Health care of baby/mother & 1 & \\
\hline & & FP & 2 & \\
\hline & & STIs & 3 & \\
\hline & & HIV/AIDS & 4 & \\
\hline & & PMTCT & 5 & \\
\hline & & Male's involvement & 6 & \\
\hline & & Other: & 7 & \\
\hline & & Don't know & 98 & \\
\hline
\end{tabular}

11. Satisfaction with services

\begin{tabular}{|l|l|l|c|}
\hline No. & QUESTIONS & \multicolumn{2}{l|}{ CODING CATEGORIES } \\
\hline 11.1 & $\begin{array}{l}\text { How long did you wait between the time you arrived } \\
\text { at this facility and the time you were able to see a } \\
\text { provider for the consultation? }\end{array}$ & Hours: & \\
\cline { 3 - 4 } & & Minutes: & 97 \\
\cline { 3 - 4 } & Saw provider immediately & 98 \\
\hline 11.2 & $\begin{array}{l}\text { Do you the think the time you waited was too long, } \\
\text { reasonable, or short? }\end{array}$ & Too long & 2 \\
\cline { 3 - 4 } & & Reasonable & 3 \\
\cline { 3 - 4 } & Short & 98 \\
\hline
\end{tabular}




\begin{tabular}{|c|c|c|c|c|}
\hline \multirow[t]{7}{*}{11.3} & $\begin{array}{l}\text { Interviewer: Explain that you will now review some } \\
\text { common experiences clients have at health facilities. As } \\
\text { you mention each one, ask the client if she was satisfied, } \\
\text { dissatisfied, or undecided about any of the services today. } \\
\text { Ability to discuss problems or concerns about your } \\
\text { pregnancy with the providers }\end{array}$ & $\frac{\text { Satisfied }}{1}$ & $\frac{\text { Dissatisfied }}{2}$ & Undecided \\
\hline & $\begin{array}{l}\text { Amount of explanation the providers gave to you about } \\
\text { a problem or treatment }\end{array}$ & 1 & 2 & 3 \\
\hline & Quality of examination and treatment provided & 1 & 2 & 3 \\
\hline & $\begin{array}{l}\text { Visual privacy during examination (that other clients } \\
\text { could not see you) }\end{array}$ & 1 & 2 & 3 \\
\hline & $\begin{array}{l}\text { Auditory privacy during discussion (that other clients } \\
\text { could not hear you) }\end{array}$ & 1 & 2 & 3 \\
\hline & Cleanliness of this facility & 1 & 2 & 3 \\
\hline & How the clinic staff treated you & 1 & 2 & 3 \\
\hline \multirow[t]{3}{*}{11.4} & Would you strongly, not strongly, or never recommend a & \multicolumn{2}{|c|}{ Strongly recommend } & 1 \\
\hline & friend to this facility for ANC? & \multicolumn{2}{|c|}{$\begin{array}{l}\text { Recommend, but not } \\
\text { strongly }\end{array}$} & 2 \\
\hline & & \multicolumn{2}{|c|}{ Never recommend } & $\begin{array}{c}3 \\
08\end{array}$ \\
\hline
\end{tabular}

12. Male involvement

\begin{tabular}{|c|c|c|c|c|}
\hline No. & QUESTIONS & CODING CATEGORIES & & GO TO \\
\hline 12.1 & Did the baby's father or your current partner & Yes & 1 & 12.3 \\
\hline & accompany you to this ANC visit? & No & 2 & \\
\hline 12.2 & During this visit, did a health provider advise you to & Yes & 1 & \\
\hline & $\begin{array}{l}\text { encourage your partner to accompany you to your ANC } \\
\text { visits? }\end{array}$ & No & 2 & \\
\hline 12.3 & During this pregnancy, has your partner beaten or & Yes & 1 & \\
\hline & insulted you at any time? & No & 2 & 12.5 \\
\hline & & No response & 99 & 12.5 \\
\hline 12.4 & Have you talked about this issue to a health provider? & Yes & 1 & \\
\hline & & No & 2 & \\
\hline 12.5 & Would you like your partner to receive information & Yes & 1 & \\
\hline & about FP methods? & No & $\frac{2}{20}$ & \\
\hline 12.6 & Would you like you and your partner to talk with & Yes & 70 & \\
\hline & somebody at this clinic about how both of you can & No & 2 & \\
\hline & protection from HIV infection? & Don't know & 98 & \\
\hline
\end{tabular}

\section{Costs}

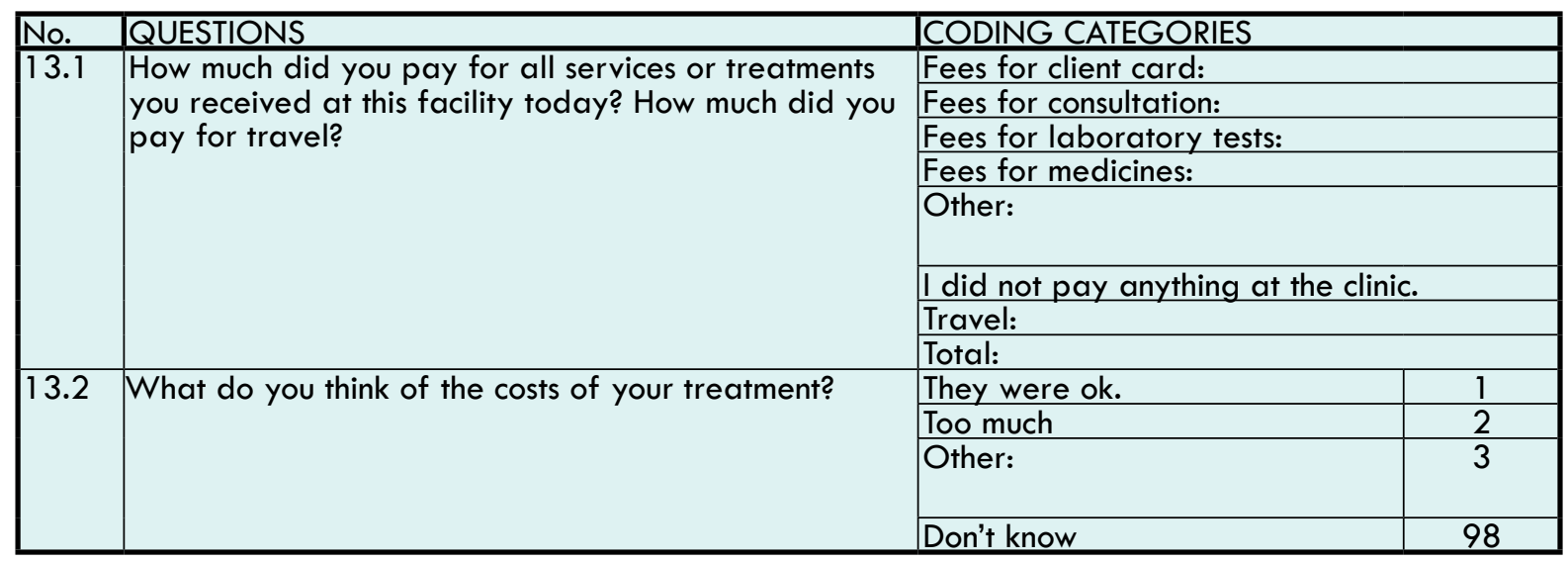


14. Accessibility

\begin{tabular}{|c|c|c|c|c|}
\hline No. & QUESTIONS & CODING CATEGORIES & & GO TO \\
\hline \multirow[t]{7}{*}{14.1} & \multirow{3}{*}{$\begin{array}{l}\text { By what means of transport did you get to } \\
\text { the clinic today? }\end{array}$} & Taxi & 1 & \\
\hline & & Bus & 2 & \\
\hline & & Train & 3 & \\
\hline & \multirow{4}{*}{ Interviewer: Mark all that apply. } & Private car & 4 & \\
\hline & & Bicycle & 5 & \\
\hline & & Walk & 6 & \\
\hline & & Other: & 7 & \\
\hline \multirow[t]{2}{*}{14.2} & \multirow{2}{*}{$\begin{array}{l}\text { Approximately how long did it take you to } \\
\text { get to the clinic today? }\end{array}$} & Hours: & & \\
\hline & & Minutes: & & \\
\hline \multirow[t]{2}{*}{14.3} & \multirow[t]{2}{*}{$\begin{array}{l}\text { Are the hours of service at this facility } \\
\text { appropriate to you? }\end{array}$} & Yes & \multicolumn{2}{|c|}{$\begin{array}{r}\text { next } \\
\text { section }\end{array}$} \\
\hline & & No & 2 & \\
\hline 14.4 & Why not? & & & \\
\hline
\end{tabular}

\section{Demographics}

No. QUESTIONS

15.1 How old are you?

15.2 What is your current marital status?

CODING CATEGORIES

Age in years: Married, monogamous Married, polygamous

Cohabiting/living with partner

Single, never married

15.3 What is the highest level of school you Divorced/separated/widowed attended?

Did not attend formal school

Primary

Secondary

Tertiary

Other: 


\section{Provider interview}

\section{INSTRUCTIONS FOR THE}

INTERVIEWER: Interview all health facility staff who are responsible for providing antenatal care, FP services to antenatal care clients, and those who participate in activities with pregnant women for PMTCT of HIV/STIs (if applicable in the study objectives). Please interview staff at the end of the working day or during their breaks. Make it clear that you are seeking their assistance in finding ways of improving the functioning and quality of the services offered by facilities in general and are not evaluating the performance of the facility or of them individually. For each item, circle the code of the adequate response or describe, as appropriate. Before beginning, read the following greeting when you meet with each provider that you will interview:
GREETING: Good morning. My name is , and I work for We are currently doing a study about the way that FP services are being integrated with antenatal care in the country and the problems that present obstacles to integration. As a part of this study, we are interviewing all health providers who participate in antenatal care, family planning services for pregnant women, and activities to prevent mother-to-child transmission of HIV. These interviews are not to evaluate individual facilities or providers. We are visiting a number of facilities. All the information you give me will be confidential, and no one will know what you said. I will not record your name in the questionnaire, and there will be no way in which the responses you give me can be directly linked to you. They will all be confidential.

\section{Facility identification}

\begin{tabular}{|c|c|c|c|}
\hline No. & QUESTIONS & \multicolumn{2}{|l|}{ CODING CATEGORIES } \\
\hline 1.1 & Date of interview & \multicolumn{2}{|l|}{$\overline{\text { (Day } / \text { Month/ Year) }}$} \\
\hline 1.2 & Facility name & & \\
\hline 1.3 & City or locality & & \\
\hline 1.4 & Type of facility & Hospital & 1 \\
\hline & & Health center with maternity ward & 2 \\
\hline & & Health center without maternity ward & 3 \\
\hline & & Health post with maternity ward & 4 \\
\hline & & Health post without maternity ward & 5 \\
\hline & & Dispensary & 6 \\
\hline & & Other: & 7 \\
\hline 1.5 & Type of sector & Government & 1 \\
\hline & & NGO & 2 \\
\hline & & Private & 3 \\
\hline & & Other: & 4 \\
\hline 1.6 & Result of the interview & Complete & 1 \\
\hline & & Incomplete & 2 \\
\hline & & Refused & 3 \\
\hline & & Other: & 4 \\
\hline
\end{tabular}


2. Demographics and professional experience

\begin{tabular}{|c|c|c|c|}
\hline \multirow{3}{*}{\begin{tabular}{|l|} 
No. \\
2.1
\end{tabular}} & $\begin{array}{l}\text { QUESTIONS } \\
\text { Sex } \\
\text { Interviewer: Please mark. }\end{array}$ & \multicolumn{2}{|l|}{ CODING CATEGORIES } \\
\hline & \multirow{2}{*}{$\begin{array}{l}\text { Sex } \\
\text { Interviewer: Please mark. }\end{array}$} & Male & 1 \\
\hline & & Female & 2 \\
\hline \multirow{10}{*}{$\mid 2.2$} & How old are you? & Age in years: & \\
\hline & \multirow[t]{9}{*}{ What is your current technical qualification? } & Specialist doctor & 1 \\
\hline & & General doctor & 2 \\
\hline & & Social service doctor & 3 \\
\hline & & Intern MD student & 4 \\
\hline & & Professional nurse & 5 \\
\hline & & Auxiliary nurse/aide & 6 \\
\hline & & Nursing student & 7 \\
\hline & & Social worker & 8 \\
\hline & & Other: & 9 \\
\hline 2.4 & $\begin{array}{l}\text { How many years ago did you graduate with this } \\
\text { degree? }\end{array}$ & Years: & \\
\hline \multirow[t]{2}{*}{2.5} & \multirow[t]{2}{*}{ How long have you been working at this facility? } & Months: & \\
\hline & & Years: & \\
\hline \multirow[t]{3}{*}{2.6} & \multirow{3}{*}{$\begin{array}{l}\text { In which unit or department are you currently } \\
\text { working? }\end{array}$} & ANC & 1 \\
\hline & & FP & 2 \\
\hline & & Other: & 3 \\
\hline \multirow[t]{15}{*}{2.7} & \multirow[t]{15}{*}{ What services do you directly provide at this facility? } & FP counseling & 1 \\
\hline & & Contraceptives & 2 \\
\hline & & ANC & 3 \\
\hline & & Delivery & 4 \\
\hline & & Postpartum care & 5 \\
\hline & & Treatment of abortion complications & 6 \\
\hline & & HIV/AIDS counseling & 7 \\
\hline & & HIV/AIDS testing & 8 \\
\hline & & HIV/AIDS treatment and care & 9 \\
\hline & & STI services & 10 \\
\hline & & Child immunization & 11 \\
\hline & & Child growth monitoring & 12 \\
\hline & & Curative services for women & 13 \\
\hline & & Curative services for children & 14 \\
\hline & & Other: & 15 \\
\hline
\end{tabular}

\section{Integration of ANC and FP}

\begin{tabular}{|c|c|c|c|c|c|c|}
\hline \multirow{9}{*}{\begin{tabular}{|l|} 
No. \\
3.1
\end{tabular}} & QUESTIONS & \multicolumn{4}{|c|}{ CODING CATEGORIES } & GO TO \\
\hline & \multirow{2}{*}{$\begin{array}{l}\text { Interviewer: Ask (a) During your in-service professional } \\
\text { training, have you ever received training in [read } 1 \text { to } 6] \text { ? } \\
\text { For every positive response ask: (b) Have you received } \\
\text { training in [...] in the past year? }\end{array}$} & \multicolumn{2}{|c|}{$\begin{array}{l}\text { (a) Ever } \\
\text { received } \\
\text { training }\end{array}$} & \multicolumn{2}{|c|}{$\begin{array}{l}\text { (b) Received } \\
\text { training last } \\
\text { year }\end{array}$} & \\
\hline & & Yes & No & Yes & No & \\
\hline & 1) Counseling/health education for maternity clients & 1 & 2 & 1 & 2 & \\
\hline & 2) FP counseling techniques & 1 & 2 & 1 & 2 & \\
\hline & 3) FP counseling for maternity clients & 1 & 2 & 1 & 2 & \\
\hline & $\begin{array}{l}\text { 4) Advantages and disadvantages of different } \\
\text { contraceptive methods }\end{array}$ & 1 & 2 & 1 & 2 & \\
\hline & $\begin{array}{l}\text { 5) Action mechanisms of different FP contraceptive } \\
\text { methods }\end{array}$ & 1 & 2 & 1 & 2 & \\
\hline & $\begin{array}{l}\text { 6) Contraindications of FP methods for postpartum } \\
\text { women }\end{array}$ & 1 & 2 & 1 & 2 & \\
\hline
\end{tabular}




\begin{tabular}{|c|c|c|c|c|c|c|}
\hline \multirow[t]{9}{*}{3.2} & \multirow{5}{*}{$\begin{array}{l}\text { What are the main services, } \\
\text { information, or orientation you } \\
\text { provide to ANC clients? }\end{array}$} & \multirow{2}{*}{\multicolumn{3}{|c|}{ Apply injection against tetanus }} & 1 & \\
\hline & & & & & 2 & \\
\hline & & \multicolumn{3}{|c|}{\begin{tabular}{|l|} 
Information about danger signs in pregnancy \\
Information about diet and nutrition \\
\end{tabular}} & 3 & \\
\hline & & \multicolumn{3}{|c|}{ Counseling about STIs } & 4 & \\
\hline & & \multicolumn{3}{|c|}{ Counseling about HIV/AIDS } & 5 & \\
\hline & \multirow{4}{*}{$\begin{array}{l}\text { Interviewer: Ask "Something else?" } \\
\text { Mark all the relevant options. }\end{array}$} & \multicolumn{3}{|c|}{ Information about breastfeeding } & 6 & \\
\hline & & \multicolumn{3}{|c|}{ FP counseling } & 7 & 3.4 \\
\hline & & \multicolumn{3}{|c|}{ Information about signs of delivery } & 8 & \\
\hline & & \multicolumn{3}{|c|}{ Other: } & 9 & \\
\hline \multirow[t]{2}{*}{3.3} & \multirow{2}{*}{\multicolumn{4}{|c|}{$\begin{array}{l}\text { During the ANC visits, do you provide information about } \\
\text { FP? }\end{array}$}} & 1 & \\
\hline & & & & & 2 & 3.13 \\
\hline \multirow[t]{6}{*}{3.4} & \multirow{2}{*}{\multicolumn{3}{|c|}{$\begin{array}{l}\text { During the ANC visits: } \\
\text { 1) Do you counsel inter } \\
\text { after delivery? }\end{array}$}} & Yes & No & \\
\hline & & & & 1 & & 2 \\
\hline & \multicolumn{3}{|c|}{ 2) Do you tell women where they can obtain an FP method after delivery? } & 1 & & 2 \\
\hline & \multicolumn{3}{|c|}{$\begin{array}{l}\text { 3) Do you inform women about the importance of using an FP method by } \\
\text { the } 40 \text { th day postpartum? }\end{array}$} & 1 & & 2 \\
\hline & \multirow{2}{*}{\multicolumn{3}{|c|}{$\begin{array}{l}\text { 4) Do you provide information about LAM (breastfeeding as an FP)? } \\
\text { 5) Do you encourage the client to visit the health clinic with her baby by } \\
\text { the } 40 \text { th day postpartum? }\end{array}$}} & 1 & & 2 \\
\hline & & & & 1 & & 2 \\
\hline \multirow[t]{5}{*}{3.5} & \multirow{2}{*}{\multicolumn{3}{|c|}{$\begin{array}{l}\text { Can you tell me the three basic principles for LAM to be an effective FP } \\
\text { method? }\end{array}$}} & & & \\
\hline & & & & Yes & No & \\
\hline & \multicolumn{3}{|c|}{$\begin{array}{l}\text { 1) Exclusive or almost exclusive breastfeeding or full-time breastfeeding } \\
\text { day and night }\end{array}$} & 1 & & 2 \\
\hline & \multicolumn{3}{|c|}{ 2) Infant must be less than 6 months old. } & 1 & & 2 \\
\hline & \multicolumn{3}{|c|}{ 3) Absence of menses since delivery } & 1 & & 2 \\
\hline \multirow[t]{6}{*}{3.6} & \multirow{2}{*}{\multicolumn{2}{|c|}{$\begin{array}{l}\text { What are the main activities you follow when } \\
\text { talking about FP to antenatal clients? }\end{array}$}} & \multicolumn{2}{|c|}{$\begin{array}{l}\text { Identify reproductive goals of } \\
\text { woman. }\end{array}$} & & 1 \\
\hline & & & $\begin{array}{l}\text { Provide information abou } \\
\text { contraceptive methods. }\end{array}$ & Jt different & & 2 \\
\hline & \multirow[t]{4}{*}{ Mark all the relevant options. } & & \multicolumn{2}{|c|}{$\begin{array}{l}\text { Discuss the client's contraceptive } \\
\text { preferences. }\end{array}$} & & 3 \\
\hline & & & \multicolumn{2}{|c|}{$\begin{array}{l}\text { Help women select a suitable } \\
\text { method. }\end{array}$} & & 4 \\
\hline & & & \multirow{2}{*}{\multicolumn{2}{|c|}{$\begin{array}{l}\text { Instruct women in how to use the } \\
\text { selected method. } \\
\text { Other: }\end{array}$}} & & 5 \\
\hline & & & & & & 6 \\
\hline
\end{tabular}




\begin{tabular}{|c|c|c|c|c|c|c|}
\hline \multirow[t]{24}{*}{3.7} & $\begin{array}{l}\text { Interviewer: Explain that you will now ask you abo } \\
\text { For each one of the next methods, please tell me } \\
\text { 1) Know the method sufficiently well to counsel ar } \\
\text { 2) Know the method sufficiently well to counsel al } \\
\text { 3) Know little about the method and would not fe } \\
\text { 4) Do not know the method }\end{array}$ & $\begin{array}{l}\text { ut the client's } \\
\text { if you: } \\
\text { id provide it } \\
\text { out it, but no } \\
\text { el comfortab }\end{array}$ & $\begin{array}{l}\text { to a client } \\
\text { ot to provide } \\
\text { ole counseling }\end{array}$ & it & $g$ it & ods. \\
\hline & & $\begin{array}{l}\text { Know well } \\
\text { to counsel } \\
\text { and } \\
\text { provide it }\end{array}$ & $\begin{array}{l}\text { Know well } \\
\text { to counsel } \\
\text { but not } \\
\text { provide }\end{array}$ & $\begin{array}{l}\text { Know little } \\
\text { about it }\end{array}$ & $\begin{array}{l}\text { Do n } \\
\text { knou }\end{array}$ & \\
\hline & 1) Combined oral contraceptives & 1 & 2 & 3 & & 4 \\
\hline & 2) Minipills (progestin-only pills) & 1 & 2 & 3 & & 4 \\
\hline & 3) Emergency contraceptive pills & 1 & 2 & 3 & & 4 \\
\hline & 4) Progestin-only injectables & 1 & 2 & 3 & & 4 \\
\hline & 5) Monthly injectables & 1 & 2 & 3 & & 4 \\
\hline & 6) Combined patches & 1 & 2 & 3 & & 4 \\
\hline & 7) Combined vaginal rings & 1 & 2 & 3 & & 4 \\
\hline & 8) Jadelle implants & 1 & 2 & 3 & & 4 \\
\hline & 9) Implanon implants & 1 & 2 & 3 & & 4 \\
\hline & 10) Sinoplant (II) implants & 1 & 2 & 3 & & 4 \\
\hline & 11) IUD & 1 & 2 & 3 & & 4 \\
\hline & 12) IUS & 1 & 2 & 3 & & 4 \\
\hline & 13) Male condoms & 1 & 2 & 3 & & 4 \\
\hline & 14) Female condoms & 1 & 2 & 3 & & 4 \\
\hline & 15) Diaphragms & 1 & 2 & 3 & & 4 \\
\hline & 16) Spermicides & 1 & 2 & 3 & & 4 \\
\hline & 17) Cervical caps & 1 & 2 & 3 & & 4 \\
\hline & 18) Female sterilization & 1 & 2 & 3 & & 4 \\
\hline & 19) Vasectomy & 1 & 2 & 3 & & 4 \\
\hline & 20) Fertility awareness methods & 1 & 2 & 3 & & 4 \\
\hline & 21) Withdrawal & 1 & 2 & 3 & & 4 \\
\hline & 22) Other: & 1 & 2 & 3 & & 4 \\
\hline \multirow[t]{2}{*}{3.8} & \multirow{2}{*}{$\begin{array}{l}\text { During the ANC visits, do you encourage women } \\
\text { to wait for some time before getting pregnant } \\
\text { again? }\end{array}$} & \multicolumn{3}{|l|}{ Yes } & 1 & \\
\hline & & \multicolumn{3}{|l|}{ No } & 2 & \\
\hline \multirow[t]{4}{*}{3.9} & \multirow{4}{*}{$\begin{array}{l}\text { According to what you know, what is the ideal } \\
\text { time interval between pregnancies to protect a } \\
\text { woman's health? }\end{array}$} & \multicolumn{3}{|c|}{ Less than 2 years } & 1 & \\
\hline & & \multirow{2}{*}{\multicolumn{3}{|c|}{\begin{tabular}{|l|}
$2-3$ years \\
$3-5$ years
\end{tabular}}} & 2 & \\
\hline & & & & & 3 & \\
\hline & & \multicolumn{3}{|l|}{ Other: } & 4 & \\
\hline \multirow[t]{2}{*}{3.10} & \multirow{2}{*}{$\begin{array}{l}\text { During the ANC visits, do you discuss with the } \\
\text { client how soon after delivery she can get } \\
\text { pregnant again? }\end{array}$} & \multicolumn{3}{|l|}{ Yes } & 1 & \\
\hline & & \multicolumn{3}{|l|}{ No } & 2 & \\
\hline \multirow[t]{5}{*}{3.11} & \multirow[t]{2}{*}{$\begin{array}{l}\text { According to what you know, how soon after } \\
\text { delivery can a woman get pregnant again? }\end{array}$} & \multicolumn{3}{|c|}{$\begin{array}{l}4 \text { weeks after delivery, if she doesn't } \\
\text { breastfeed exclusively }\end{array}$} & 1 & \\
\hline & & As soon as $\mathrm{m}$ & menstruation & resumes & 2 & \\
\hline & Interviewer: Mark all the relevant options. & $\begin{array}{l}\text { After } 6 \text { mont } \\
\text { exclusively }\end{array}$ & ths, if she bre & eastfeeds & 3 & \\
\hline & & Other: & & & 4 & \\
\hline & & Don't know & & & 98 & \\
\hline 3.12 & What are the main difficulties you have had & Lack of supp & plies & & 1 & \\
\hline & in this facility in providing FP services for ANC & Lack of qual & lified personr & inel & 2 & \\
\hline & clients in the last 3 months? & Lack of equi & ipment & & 3 & \\
\hline & & Failures in ec & quipment & & 4 & \\
\hline & & Inappropriat & te facilities & & 5 & \\
\hline & & Do not feels & sufficiently tro & rained & 6 & \\
\hline & & Not enough & time to couns & sel clients & 7 & \\
\hline & & Other: & & & 8 & \\
\hline
\end{tabular}




\begin{tabular}{|c|c|c|c|}
\hline \multirow[t]{3}{*}{3.13} & \multirow{3}{*}{$\begin{array}{l}\text { Are there any written guidelines in this facility for } \\
\text { providing FP services to ANC clients? }\end{array}$} & Yes & 1 \\
\hline & & No & $2 \begin{array}{r}\text { next } \\
\text { section }\end{array}$ \\
\hline & & Don't know & $98 \begin{array}{r}\text { next } \\
\text { section }\end{array}$ \\
\hline 3.14 & $\begin{array}{l}\text { How well do you know the guidelines for } \\
\text { providing FP services to ANC clients? }\end{array}$ & \begin{tabular}{|l|} 
Very well \\
Fairly well \\
Not well
\end{tabular} & $\begin{array}{l}1 \\
2 \\
3\end{array}$ \\
\hline
\end{tabular}

4. ANC experience, knowledge, and practices

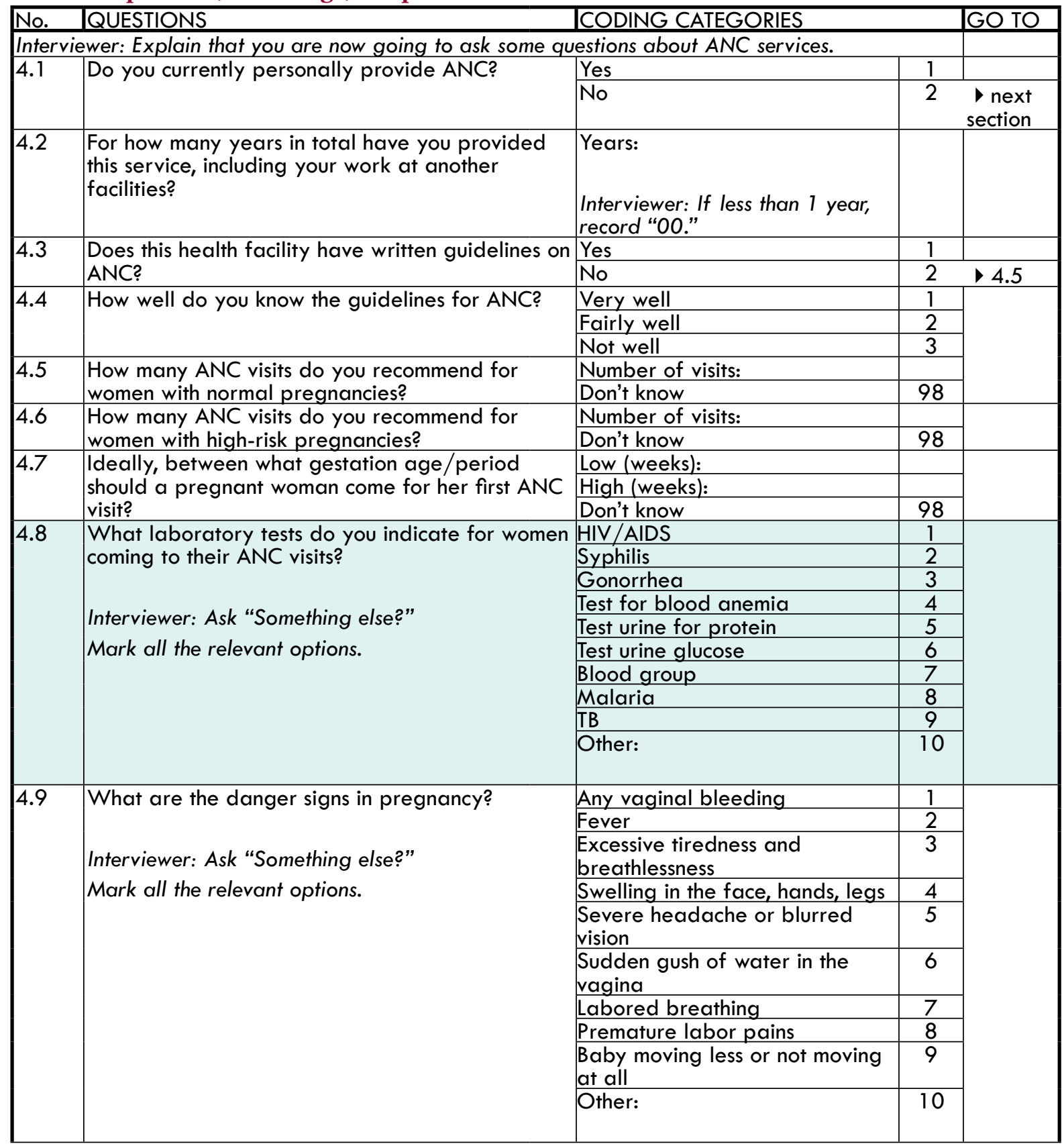




\begin{tabular}{|c|c|c|c|}
\hline 4.10 & $\begin{array}{l}\text { When counseling a woman about } \\
\text { preparations for delivery, what topics do you }\end{array}$ & $\begin{array}{l}\text { When baby is due for delivery } \\
\text { Identify a health facility for any }\end{array}$ & $\frac{1}{2}$ \\
\hline & $\begin{array}{l}\text { discuss with her? } \\
\text { dity }\end{array}$ & $\begin{array}{l}\text { emergency } \\
\text { eme }\end{array}$ & \\
\hline & (1) & $\begin{array}{l}\text { Identifying a health facility for } \\
\text { delivery }\end{array}$ & 3 \\
\hline & Interviewer: Ask "Something else?" & Putting money aside in case of & 4 \\
\hline & Mark all the relevant options. & emergency & \\
\hline & & $\begin{array}{l}\text { Planning transport in case of } \\
\text { emergency and delivery }\end{array}$ & 5 \\
\hline & & Having a birth partner during birth & 6 \\
\hline & & Collecting and preparing the basic & 7 \\
\hline & & Other: & 8 \\
\hline 4.11 & What are the main difficulties you have had & Lack of supplies & 1 \\
\hline & in this facility in providing ANC to women in & Lack of qualified personnel & 2 \\
\hline & the last 3 months? & Lack of equipment & 3 \\
\hline & & Failures in equipment & 4 \\
\hline & & Inappropriate facilities & 5 \\
\hline & & Do not feel adequately trained & 6 \\
\hline & & Not enough time to treat clients & 7 \\
\hline & & Other: & 8 \\
\hline & & Don't know & 9 \\
\hline
\end{tabular}

\section{Supervision}

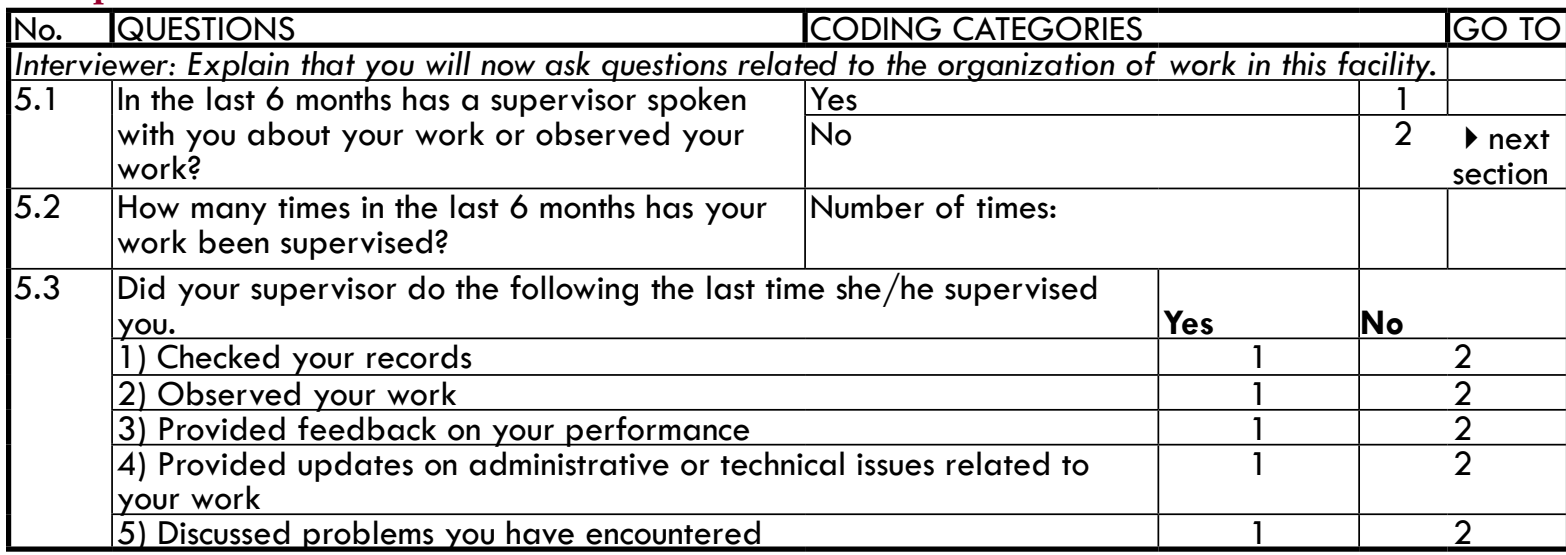

\section{PMTCT of HIV}

\begin{tabular}{|c|c|c|c|c|c|c|}
\hline No. & QUESTIONS & \multicolumn{4}{|c|}{ CODING CATEGORIES } & GO TO \\
\hline \multirow[t]{7}{*}{6.1} & \multirow{2}{*}{$\begin{array}{l}\text { Interviewer: Explain that you will now } \\
\text { discuss the integration of ANC and PMTCT } \\
\text { of HIV. Ask the following. (a) During your } \\
\text { in-service professional training, have you } \\
\text { ever received training in (read } 1 \text { to } 17 \text { ? } \\
\text { For every positive response ask: (b) Have } \\
\text { you received training in [...] in the past } \\
\text { year? }\end{array}$} & \multicolumn{2}{|c|}{$\begin{array}{l}\text { (a) Ever received } \\
\text { training }\end{array}$} & \multicolumn{2}{|c|}{$\begin{array}{l}\text { (b) Received training } \\
\text { last year }\end{array}$} & \\
\hline & & Yes & No & Yes & No & \\
\hline & 1) PMTCT of HIV & 1 & 2 & 1 & 2 & \\
\hline & 2) Counseling for prevention of HIV & 1 & 2 & 1 & 2 & \\
\hline & $\begin{array}{l}\text { 3) Counseling/social support for HIV/AIDS } \\
\text { infected clients }\end{array}$ & 1 & 2 & 1 & 2 & \\
\hline & $\begin{array}{l}\text { 4) Medical management of HIV/AIDS } \\
\text { infected clients }\end{array}$ & 1 & 2 & 1 & 2 & \\
\hline & $\begin{array}{l}\text { 5) ARV therapy for HIV/AIDS infected } \\
\text { clients }\end{array}$ & 1 & 2 & 1 & 2 & \\
\hline 6.2 & \begin{tabular}{|l|l} 
During ANC visits, do you provide & Yes \\
\cline { 2 - 2 }
\end{tabular} & & & & 1 & \\
\hline & $\begin{array}{l}\text { information or counseling to pregnant No } \\
\text { women about HIV/AIDS? }\end{array}$ & & & & 2 & $\begin{array}{l}\text { next } \\
\text { section }\end{array}$ \\
\hline
\end{tabular}




\begin{tabular}{|c|c|c|c|c|}
\hline \multirow[t]{3}{*}{6.3} & \multirow{3}{*}{$\begin{array}{l}\text { Does this health facility have } \\
\text { guidelines on PMTCT of HIV in ANC } \\
\text { clients? }\end{array}$} & Yes & 1 & \\
\hline & & No & 2 & 6.5 \\
\hline & & Don't know & 98 & 6.5 \\
\hline \multirow[t]{3}{*}{6.4} & \multirow{3}{*}{$\begin{array}{l}\text { How well do you know these } \\
\text { guidelines? }\end{array}$} & Very well & 1 & \\
\hline & & Fairly well & 2 & \\
\hline & & Not well & 3 & \\
\hline \multirow[t]{6}{*}{6.5} & \multirow{6}{*}{$\begin{array}{l}\text { Please describe the four pillars } \\
\text { (prongs) of PMTCT. }\end{array}$} & Primary prevention of HIV infection & 1 & \\
\hline & & $\begin{array}{l}\text { Prevention of unintended pregnancies among } \\
\text { HIV-positive women }\end{array}$ & 2 & \\
\hline & & $\begin{array}{l}\text { Prevention of HIV transmission from HIV- } \\
\text { infected women to their children }\end{array}$ & 3 & \\
\hline & & $\begin{array}{l}\text { Treatment, care, and support of HIV-infected } \\
\text { women and their families }\end{array}$ & 4 & \\
\hline & & Other: & 5 & \\
\hline & & Don't know & 98 & \\
\hline \multirow[t]{11}{*}{6.6} & \multirow{2}{*}{$\begin{array}{l}\text { What is the main information or } \\
\text { counseling about HIV/AIDS that you } \\
\text { provide to women during their ANC } \\
\text { visits? }\end{array}$} & $\begin{array}{l}\text { A woman with HIV can transmit it to her } \\
\text { baby without appropriate care. }\end{array}$ & 1 & \\
\hline & & $\begin{array}{l}\text { A woman with HIV can transmit it to her } \\
\text { baby if she breastfeeds. }\end{array}$ & 2 & \\
\hline & Interviewer: Ask "Anything else?" & $\begin{array}{l}\text { Breastfeeding exclusively reduces the chance } \\
\text { that a woman with HIV transmits it to her } \\
\text { baby. }\end{array}$ & 3 & \\
\hline & \multirow{8}{*}{$\begin{array}{l}\text { Interviewer: Ask "Anything else?" } \\
\text { Mark all the relevant options. }\end{array}$} & $\begin{array}{l}\text { There are medicines to help prevent HIV } \\
\text { transmission from a woman to her baby. }\end{array}$ & 4 & \\
\hline & & $\begin{array}{l}\text { Having multiple sex partners increases risks } \\
\text { of HIV infection. }\end{array}$ & 5 & \\
\hline & & $\begin{array}{l}\text { Risk of HIV infection is high if partner has } \\
\text { multiple sex partners. }\end{array}$ & 6 & \\
\hline & & Using condoms reduces risk of HIV infection. & 7 & \\
\hline & & Abstinence reduces risk of HIV infection. & 8 & \\
\hline & & $\begin{array}{l}\text { A pregnant woman needs to be tested for } \\
\text { HIV. }\end{array}$ & 9 & \\
\hline & & The partner needs to be tested for HIV. & 10 & \\
\hline & & Other: & 11 & \\
\hline \multirow[t]{10}{*}{6.7} & \multirow{4}{*}{$\begin{array}{l}\text { What kind of messages would you } \\
\text { give to HIV-positive mothers to } \\
\text { promote safer breastfeeding? }\end{array}$} & Exclusive breastfeeding ( 6 months) & 1 & \\
\hline & & Wean abruptly & 2 & \\
\hline & & Mother to ensure baby is attached and & 3 & \\
\hline & & $\begin{array}{l}\text { positioned to breast properly to prevent } \\
\text { nipple problems }\end{array}$ & & \\
\hline & \multirow[t]{6}{*}{$\begin{array}{l}\text { Interviewer: Mark all the relevant } \\
\text { responses. }\end{array}$} & $\begin{array}{l}\text { To promptly seek medical attention for } \\
\text { breast problems }\end{array}$ & 4 & \\
\hline & & At about 6 months, mother can provide food & 5 & \\
\hline & & $\begin{array}{l}\text { at least } 3 \text { times a day and give fresh fruits } \\
\text { and vegetables. }\end{array}$ & & \\
\hline & & Mothers and their partners should practice & 6 & \\
\hline & & $\begin{array}{l}\text { safer sex. } \\
\text { When to take her and baby's medications }\end{array}$ & 7 & \\
\hline & & Other: & 8 & \\
\hline \multirow[t]{8}{*}{6.8} & \multirow{4}{*}{$\begin{array}{l}\text { What counseling do you give to all } \\
\text { clients for PMTCT of HIV during the } \\
\text { postpartum period? }\end{array}$} & Do not give any counseling & 1 & \\
\hline & & Routine testing and counseling for HIV & 2 & \\
\hline & & Avoid STls by using condoms & 3 & \\
\hline & & Being faithful & 4 & \\
\hline & \multirow{4}{*}{$\begin{array}{l}\text { Interviewer: Mark all relevant } \\
\text { responses. }\end{array}$} & Having a faithful partner & 5 & \\
\hline & & Avoid mother's HIV infection by practicing & 6 & \\
\hline & & Encourage partner testing & 7 & \\
\hline & & Other: & 8 & \\
\hline
\end{tabular}




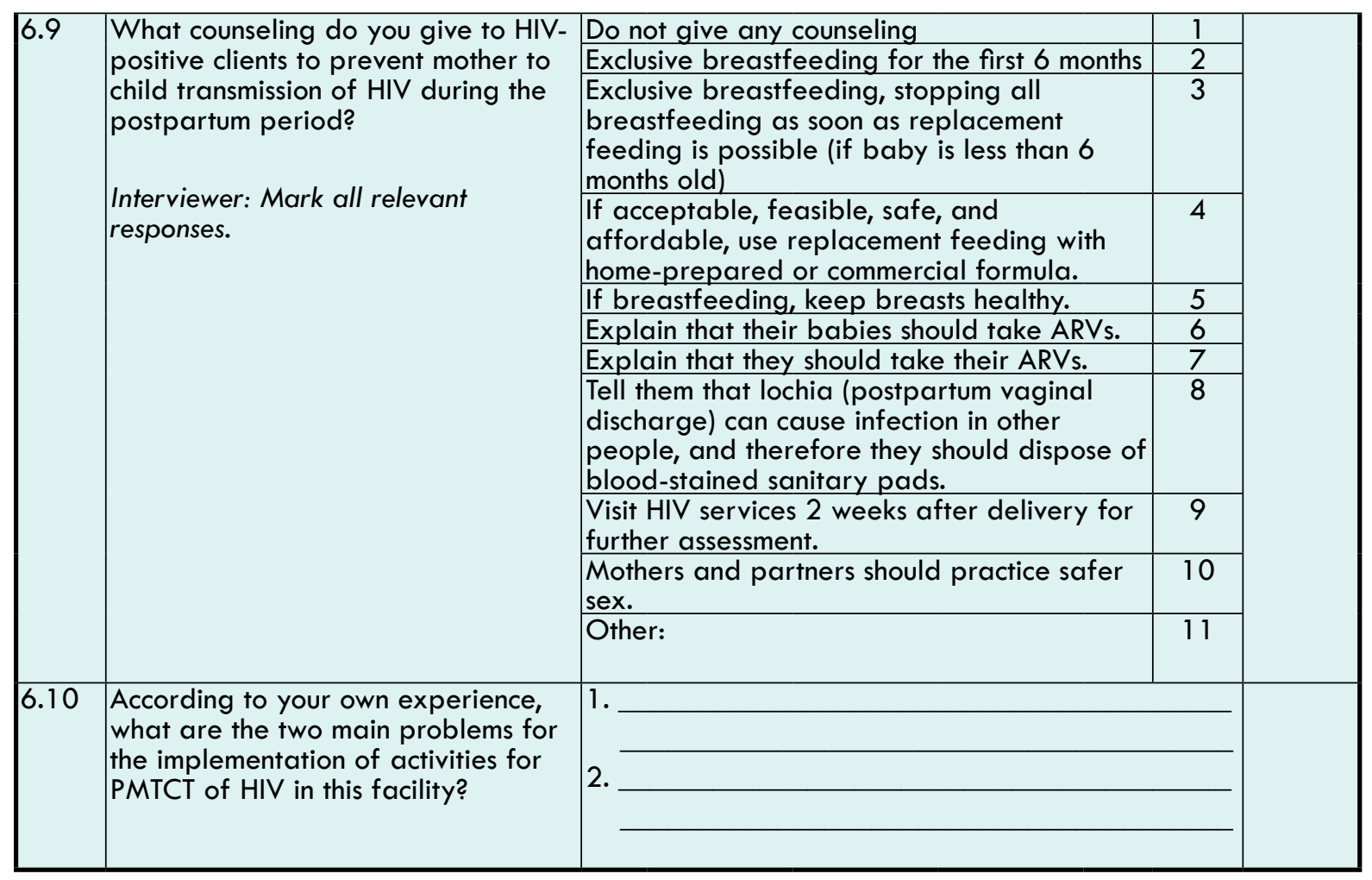

\section{PMTCT of STIs}

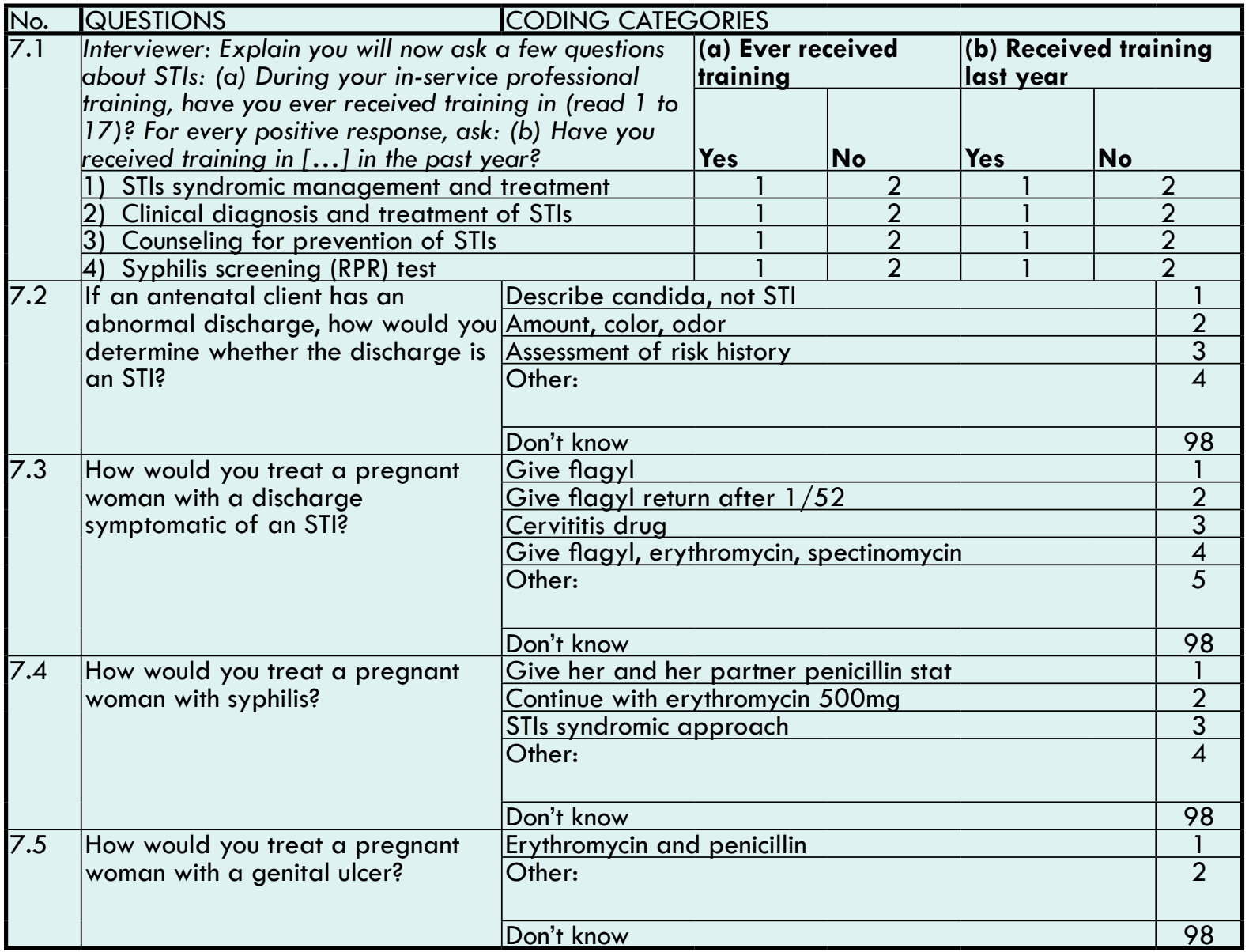


8. Malaria

\begin{tabular}{|c|c|c|c|c|}
\hline No. & QUESTIONS & CODING CATEGORIES & & GO TO \\
\hline Inter & ewer: Explain that you will now ask que & tions about malaria. & & \\
\hline 8.1 & $\begin{array}{l}\text { Please mention three ways of } \\
\text { controlling malaria in pregnancy. }\end{array}$ & $\begin{array}{l}\text { Counsel client about use of treated bed } \\
\text { nets/mosquito nets }\end{array}$ & 1 & \\
\hline & . & $\begin{array}{l}\text { Intermittent preventive treatment (IPT) with } \\
\text { SP (fansidar) }\end{array}$ & 2 & \\
\hline & Interviewer: Mark all that apply. & Case management of symptomatic women & 3 & \\
\hline & & Other: & 4 & \\
\hline & & Don't know & 98 & \\
\hline 8.2 & What antimalarial drug is & SP - Fansidar & 1 & \\
\hline & recommended for use among & Other: & 2 & 7.4 \\
\hline & & Don't know & 98 & 7.4 \\
\hline 8.3 & $\begin{array}{l}\text { At what stages in a woman's } \\
\text { pregnancy should you administer }\end{array}$ & $\begin{array}{l}\text { During the } 2 \text { nd trimester ( } 16 \text { to } 24 \text { weeks } / 4 \\
\text { to } 6 \text { months) }\end{array}$ & 1 & \\
\hline & the 1 st dose of antimalarial (SP) to & Other: & 2 & \\
\hline & & Don't know & 98 & \\
\hline 8.4 & $\begin{array}{l}\text { At what stages in a woman's } \\
\text { pregnancy should you administer }\end{array}$ & $\begin{array}{l}\text { During the } 3 \text { rd trimester ( } 24 \text { to } 36 \text { weeks } / 6 \\
\text { to } 8 \text { months) }\end{array}$ & 1 & \\
\hline & the 2 nd dose of antimalarial (SP) to & Other: & 2 & \\
\hline & & Don't know & 98 & \\
\hline
\end{tabular}

\section{Anemia}

\begin{tabular}{|c|c|c|c|}
\hline No. & QUESTIONS & CODING CATEGORIES & \\
\hline Inter & ewer: Explain that you will now ask qu & stions about anemia. & \\
\hline 9.1 & What are the four major causes of & Iron deficiency & 1 \\
\hline & anemia in pregnancy? & Hookworms & 2 \\
\hline & & Malaria & 3 \\
\hline & & Advanced HIV/AIDS & 4 \\
\hline & Interviewer: Mark all that apply. & Other: & 5 \\
\hline & & Don't know & 98 \\
\hline 9.2 & How would you look for signs and & Hemoglobin testing & 1 \\
\hline & symptoms of anemia in your clients? & Ask client whether legs feel heavy. & 2 \\
\hline & & $\begin{array}{l}\text { Ask client whether she sometimes has difficulty } \\
\text { walking. }\end{array}$ & 3 \\
\hline & $\begin{array}{l}\text { Interviewer: Mark all that apply. Ask } \\
\text { "Something else?" }\end{array}$ & $\begin{array}{l}\text { Ask client whether she sometimes has buzzing in } \\
\text { the ears. }\end{array}$ & 4 \\
\hline & & $\begin{array}{l}\text { Ask client whether she sometimes feels } \\
\text { palpitations (heart running fast). }\end{array}$ & 5 \\
\hline & & $\begin{array}{l}\text { Ask client whether she sometimes has dizziness } \\
\text { that stops her from walking. }\end{array}$ & 6 \\
\hline & & $\begin{array}{l}\text { Examine client's palms, nail beds, inner eyelids, } \\
\text { and tongue (pallor). }\end{array}$ & 7 \\
\hline & & Other: & 8 \\
\hline
\end{tabular}




\section{Data collection instruments for the integration of family planning with postnatal care services}

This section contains the four basic instruments for conducting an AIM on the integration of FP and postnatal care (PNC) services. PNC includes integrated services for the mother and the child.

Instruments are presented in the following order:

\section{A) Inventory for facilities available and services provided at the facility}

B) Observation guide

C) Questionnaire for clients' exit interviews

D) Questionnaire for providers' interviews

Since some may be interested in using AIM to gather information exclusively about the integration of PNC and FP services, while others may want to take advantage of a research team already visiting the facility to obtain information about the general quality of PNC services, the instruments contain questions that are relevant for both purposes. The first two modules of the inventory and the observation guide, and the first three modules of the provider's and client's interviews are designed to serve as a questionnaire that can easily be adapted to any study that focuses exclusively on measuring the integration of PNC and FP services.

All the modules that follow the one labeled "Integration of PNC and Family Planning Services" are designed to assess different components of the quality of PNC services. Those interested in this aspect can adapt the whole instruments to their own context. Some of the questions in these modules are relevant only in certain contexts or for specific objectives, such as those that refer to the activities for PMTCT of transmission of HIV and STIs, or the questions about costs. These optional questions are shaded for easy identification.
We recommend that only those questions that are directly linked to the objectives of each study (as defined by the researchers) are included in the final questionnaires. Otherwise, research teams risk wasting money and time collecting too much information that will not be used.

\section{A. Inventory for facilities available and services provided at the facility}

\section{INSTRUCTIONS TO DATA}

COLLECTOR: This inventory should be completed by observing the facilities that are available and having discussions with the person in charge of PNC on the day of the visit. For some questions, you may also have to talk to the person in charge of FP.

For some of the questions in this instrument, you will have to observe directly the availability of equipment, supplies, and infrastructure. Ask the clinic staff member who is assisting you to direct you to the room, laboratory, or storage area that you need to verify. In all cases, you should verify that the items exist by actually observing them yourself; if you are not able to observe them, then code accordingly. Remember that the objective of the inventory is to identify equipment and facilities that currently exist and are in working order and not to evaluate the performance of the staff or the clinic. For each item, circle the code of the most suitable response or describe as appropriate. Before beginning, read the following greeting when you meet with the person who will help you fill this instrument: 
GREETING: Good morning. My name is , and I work for

We are currently doing a study about the way that family planning services are being integrated with postnatal care in the country and the problems that interfere with the integration. This is not an evaluation of this facility or of the staff who provide us this information. We are visiting a number of facilities. All the information will be combined, and all the information you provide me will be confidential. No one will know what you said. Are you willing to assist?

1. Facility identification

\begin{tabular}{|c|c|c|c|}
\hline No. & QUESTIONS & \multicolumn{2}{|l|}{ CODING CATEGORIES } \\
\hline 1.1 & Date of observations & (Day/Month/ Year) & \\
\hline 1.2 & Facility name & & \\
\hline 1.3 & City or locality & & \\
\hline \multirow[t]{7}{*}{1.4} & \multirow[t]{7}{*}{ Type of facility } & Hospital & 1 \\
\hline & & Health center with maternity ward & 2 \\
\hline & & Health center without maternity ward & 3 \\
\hline & & Health post with maternity ward & 4 \\
\hline & & Health post without maternity ward & 5 \\
\hline & & Dispensary & 6 \\
\hline & & Other (specify): & 7 \\
\hline \multirow[t]{4}{*}{1.5} & \multirow[t]{4}{*}{ Type of sector } & Government & 1 \\
\hline & & NGO & 2 \\
\hline & & Private & 3 \\
\hline & & Other (specify): & 4 \\
\hline \multirow[t]{4}{*}{1.6} & \multirow[t]{4}{*}{ Result of the inventory } & Complete & 1 \\
\hline & & Incomplete & 2 \\
\hline & & Refused & 3 \\
\hline & & Other (specify): & 4 \\
\hline
\end{tabular}

2. Questions to measure the integration between FP and PNC services

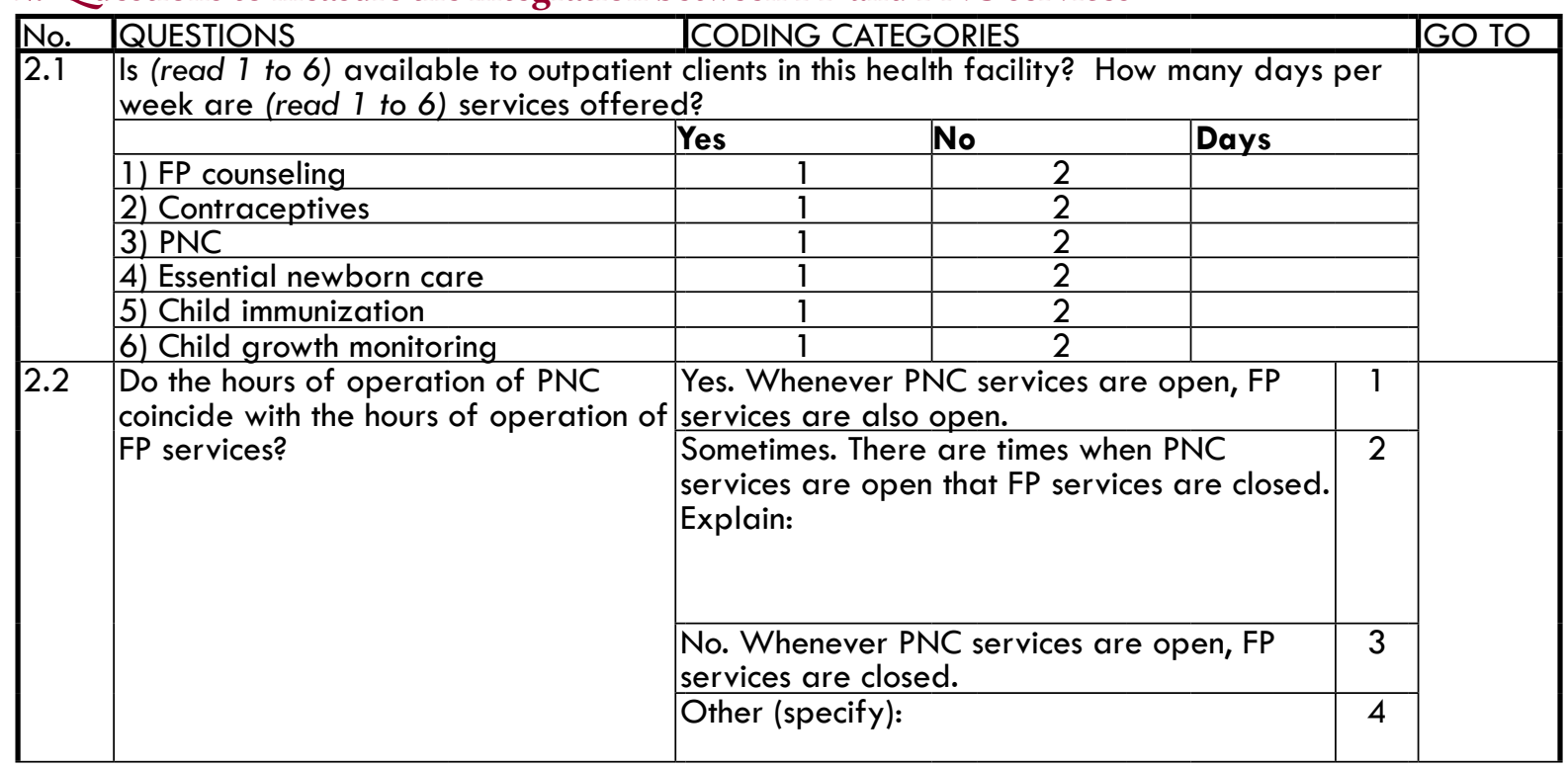




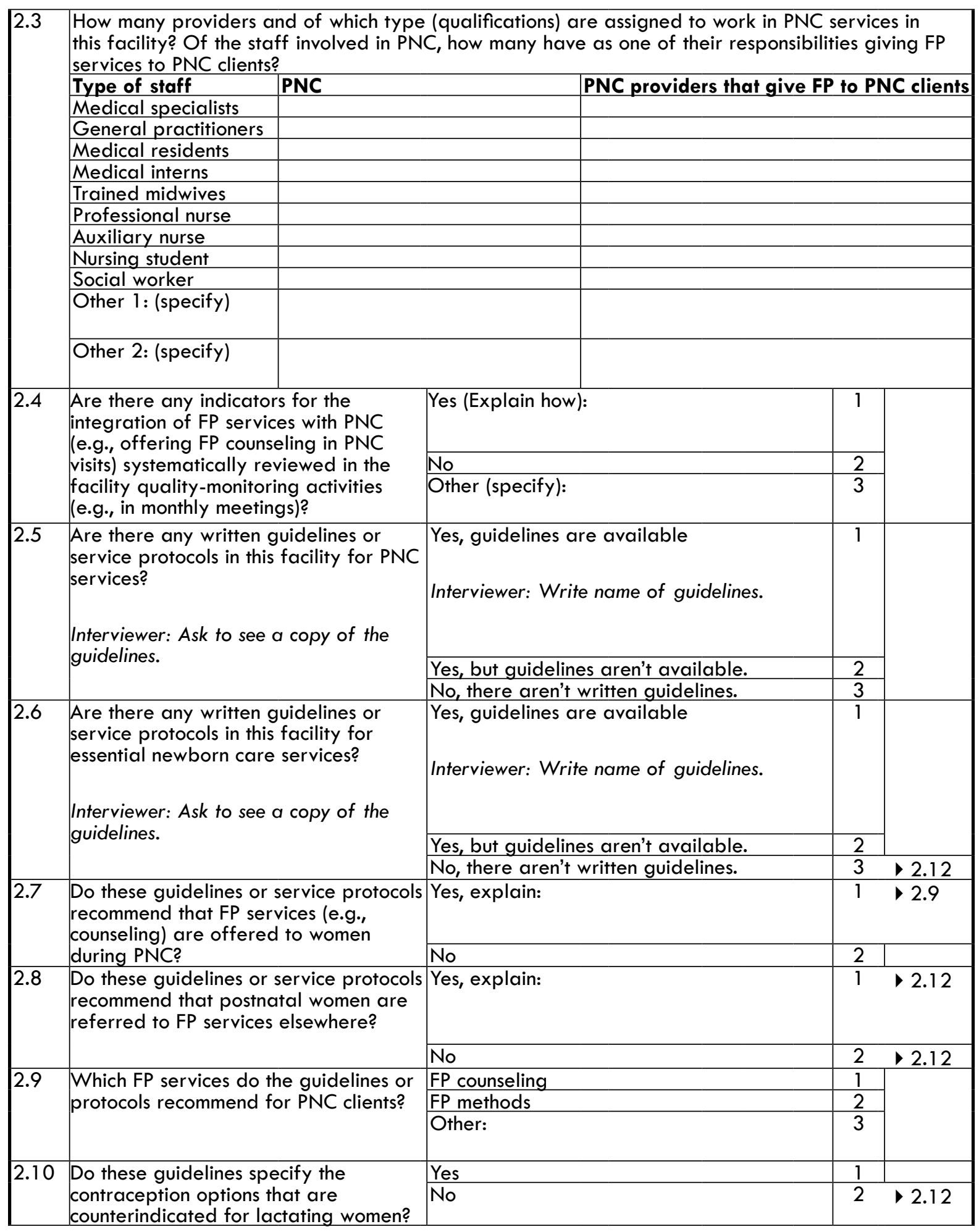




\begin{tabular}{|c|c|c|c|c|}
\hline 2.11 & According to these guidelines, & Combined oral contraceptives & 1 & \\
\hline & which contraceptive options are & Minipills (progestin-only pills) & 2 & \\
\hline & counterindicated for lactating women? & Emergency contraceptive pills & 3 & \\
\hline & & Progestin-only injectables & 4 & \\
\hline & & Monthly injectables & 5 & \\
\hline & Interviewer: Mark all that apply. & Combined patches & 6 & \\
\hline & & Combined vaginal rings & 7 & \\
\hline & & Jadelle implants & 8 & \\
\hline & & Implanon implants & 9 & \\
\hline & & Sinoplant (II) implants & 10 & \\
\hline & & IUD & 11 & \\
\hline & & IUS & 12 & \\
\hline & & Male condoms & 13 & \\
\hline & & Female condoms & 14 & \\
\hline & & Diaphragms & 15 & \\
\hline & & Spermicides & 16 & \\
\hline & & Cervical caps & 17 & \\
\hline & & Female sterilization & 18 & \\
\hline & & Vasectomy & 19 & \\
\hline & & Fertility awareness methods & 20 & \\
\hline & & Withdrawal & 21 & \\
\hline & & LAM & 22 & \\
\hline & & Other: & 23 & \\
\hline 2.12 & Is FP counseling routinely offered to & Yes & 1 & \\
\hline & $\begin{array}{l}\text { PNC clients in this facility? (By routinely, } \\
\text { we mean offered to most patients.) }\end{array}$ & No & 2 & 2.19 \\
\hline 2.13 & $\begin{array}{l}\text { For which PNC clients is FP information } \\
\text { routinely offered? (E.g., is it offered } \\
\text { only to clients in their first visit?) }\end{array}$ & Explain: & & \\
\hline 2.14 & Do PNC clients receive FP counseling & Yes & 1 & \\
\hline & at the same time that they receive their & No & 2 & \\
\hline & PNC consultation? & Other: & 3 & \\
\hline 2.15 & Who gives FP counseling to PNC & Same provider & 1 & \\
\hline & clients? The same provider who gives & Someone else & 2 & \\
\hline & them PNC or someone else? & Other: & 3 & \\
\hline 2.16 & $\begin{array}{l}\text { Where do PNC clients receive FP } \\
\text { information? }\end{array}$ & $\begin{array}{l}\text { In the same area where they receive PNC } \\
\text { services }\end{array}$ & 1 & 2.18 \\
\hline & & In the FP services in this facility & 2 & \\
\hline & & Other: & 3 & \\
\hline 2.17 & Why is FP information not provided in & There is not staff available. & 1 & \\
\hline & the same area where women receive & Staff is not trained. & 2 & \\
\hline & PNC? & Do not have the necessary equipment & 3 & \\
\hline & & Insufficient room/space & 4 & \\
\hline & & Other: & 5 & \\
\hline
\end{tabular}




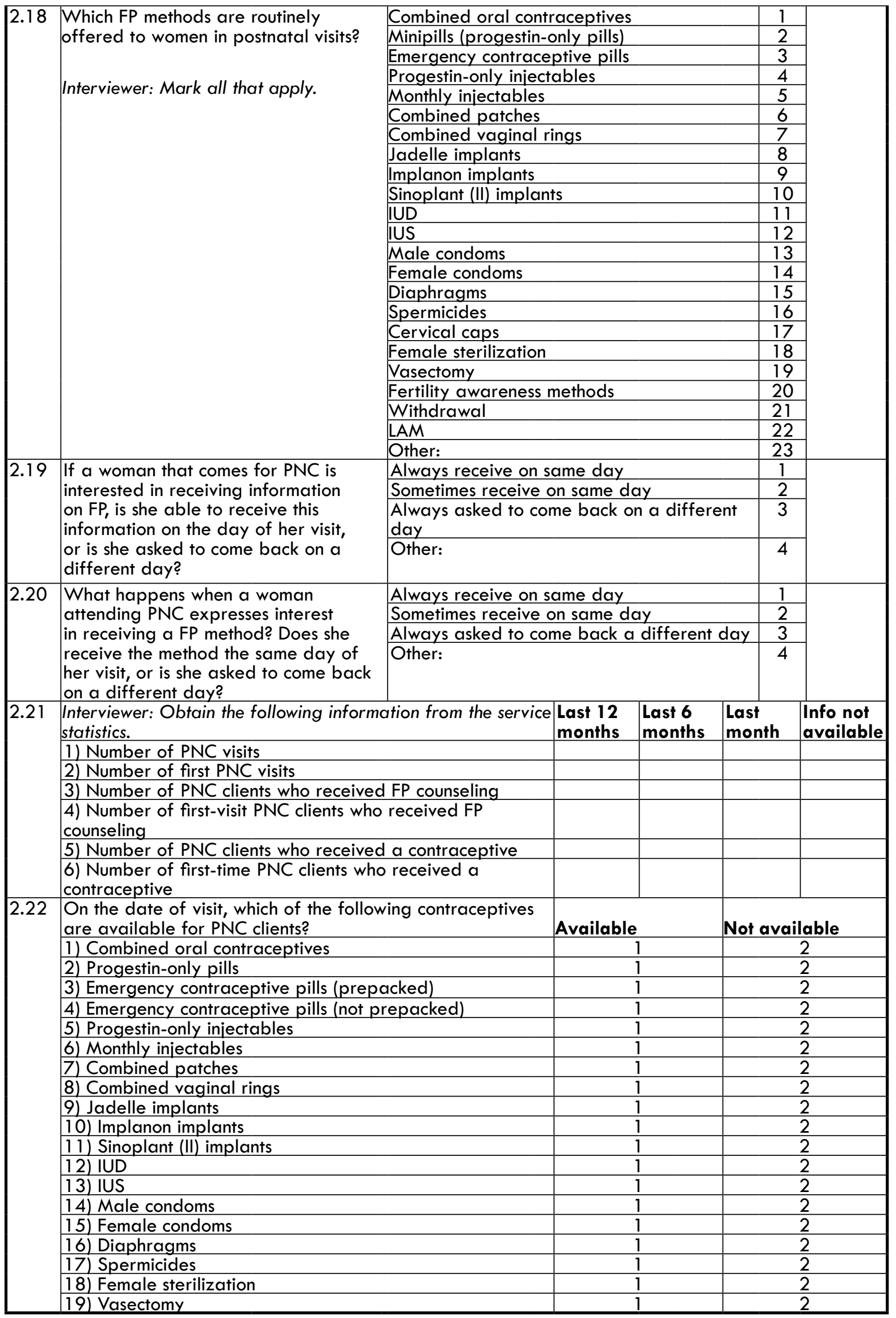


3. Description of district and its functioning

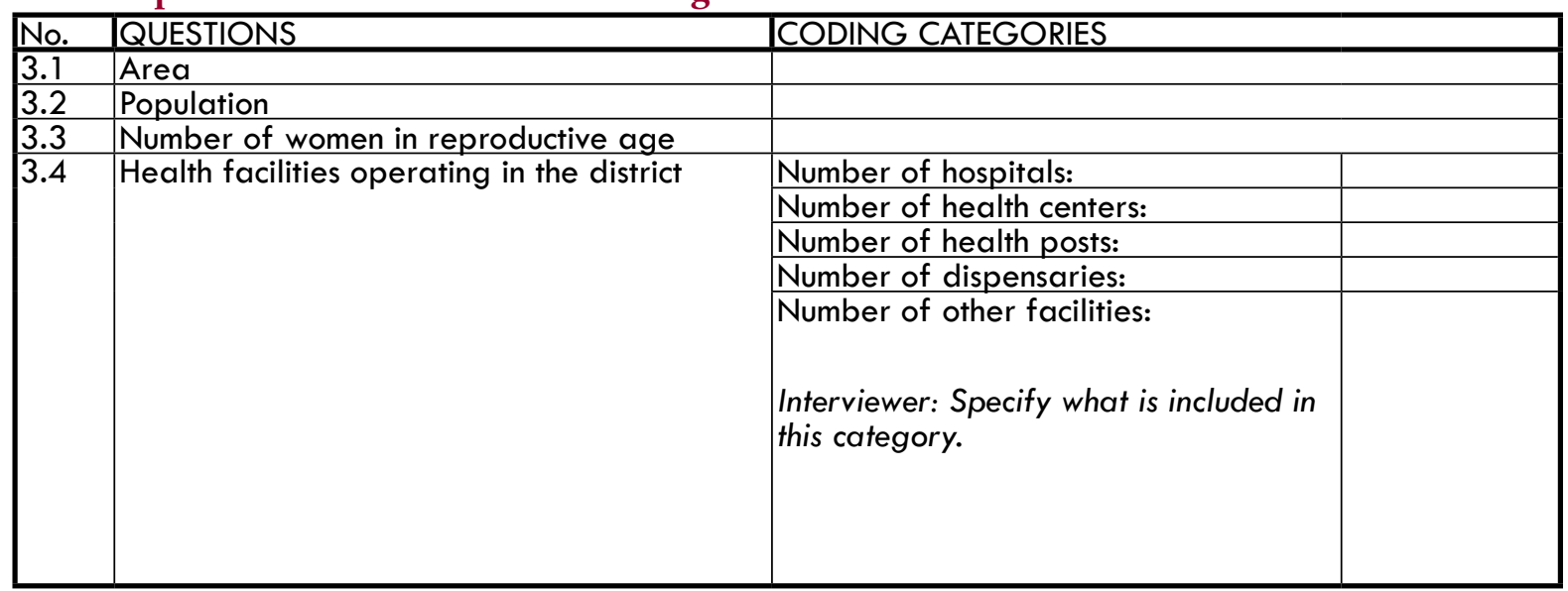

\section{Hours of operation}

\begin{tabular}{|l|l|l|l|}
\hline No. & QUESTIONS & CODING CATEGORIES \\
\hline 4.1 & $\begin{array}{l}\text { Routinely, how many days per week is the facility open for } \\
\text { outpatient services? }\end{array}$ & Days: \\
\hline 4.2 & $\begin{array}{l}\text { What are the opening and closing hours for outpatient } \\
\text { services at this facility? }\end{array}$ & $\begin{array}{l}\text { Opening time } \\
\text { Closing time }\end{array}$ & (Hour : Minutes) \\
\hline 4.3 & $\begin{array}{l}\text { Is there a nurse or doctor present at the facility at all times? } \\
\text { (24 hours/day) }\end{array}$ & Yes & No \\
\cline { 2 - 4 } 4.4 & $\begin{array}{l}\text { Is there a nurse or doctor available on call at all times after } \\
\text { hours? }\end{array}$ & Yes & No \\
\cline { 2 - 4 }
\end{tabular}

\section{Services available/staff}

\begin{tabular}{|c|c|c|c|c|}
\hline \multirow[t]{18}{*}{$\frac{\text { No. }}{5.1}$} & \multicolumn{4}{|c|}{$\begin{array}{l}\text { Is (read } 1 \text { to } 16 \text { ) available to outpatient clients in this health facility? How many days per week are } \\
\text { (read } 1 \text { to } 16 \text { ) services offered? }\end{array}$} \\
\hline & & Yes & No & Days \\
\hline & 1) FP counseling & 1 & 2 & \\
\hline & 2) Contraceptives & 1 & 2 & \\
\hline & 3) Antenatal care & 1 & 2 & \\
\hline & 4) Delivery & 1 & 2 & \\
\hline & 5) $\mathrm{PNC}$ & 1 & 2 & \\
\hline & 6) Treatment of abortion complications & 1 & 2 & \\
\hline & 7) HIV/AIDS counseling & 1 & 2 & \\
\hline & 8) HIV/AIDS testing & 1 & 2 & \\
\hline & 9) HIV/AIDS treatment and care & 1 & 2 & \\
\hline & 10) Services for STIs & 1 & 2 & \\
\hline & 11) Essential newborn care & 1 & 2 & \\
\hline & 12) Child immunization & 1 & 2 & \\
\hline & 13) Child growth monitoring & 1 & 2 & \\
\hline & 14) Curative services for women & 1 & 2 & \\
\hline & 15) Curative services for children & 1 & 2 & \\
\hline & 16) Other: & & & \\
\hline 5.2 & Do you have staff shortages in (read 1 to 4 ) services? & & Yes & No \\
\hline & 1) PNC & & 1 & 2 \\
\hline & 2) FP & & 1 & 2 \\
\hline & 3) STI & & 1 & 2 \\
\hline & 4) $\mathrm{HIV} / \mathrm{VCT}$ & & 1 & 2 \\
\hline
\end{tabular}




\begin{tabular}{|c|c|c|c|}
\hline \multirow[t]{10}{*}{5.3} & \multirow[t]{10}{*}{ What types of staff shortages are most critical? } & Medical specialists & 1 \\
\hline & & General practitioners & 2 \\
\hline & & Medical residents & 3 \\
\hline & & Medical interns & 4 \\
\hline & & Trained midwives & 5 \\
\hline & & Professional nurse & 6 \\
\hline & & Auxiliary nurse & 7 \\
\hline & & Nursing student & 8 \\
\hline & & Social worker & 9 \\
\hline & & Other: & 10 \\
\hline
\end{tabular}

\section{Supervision}

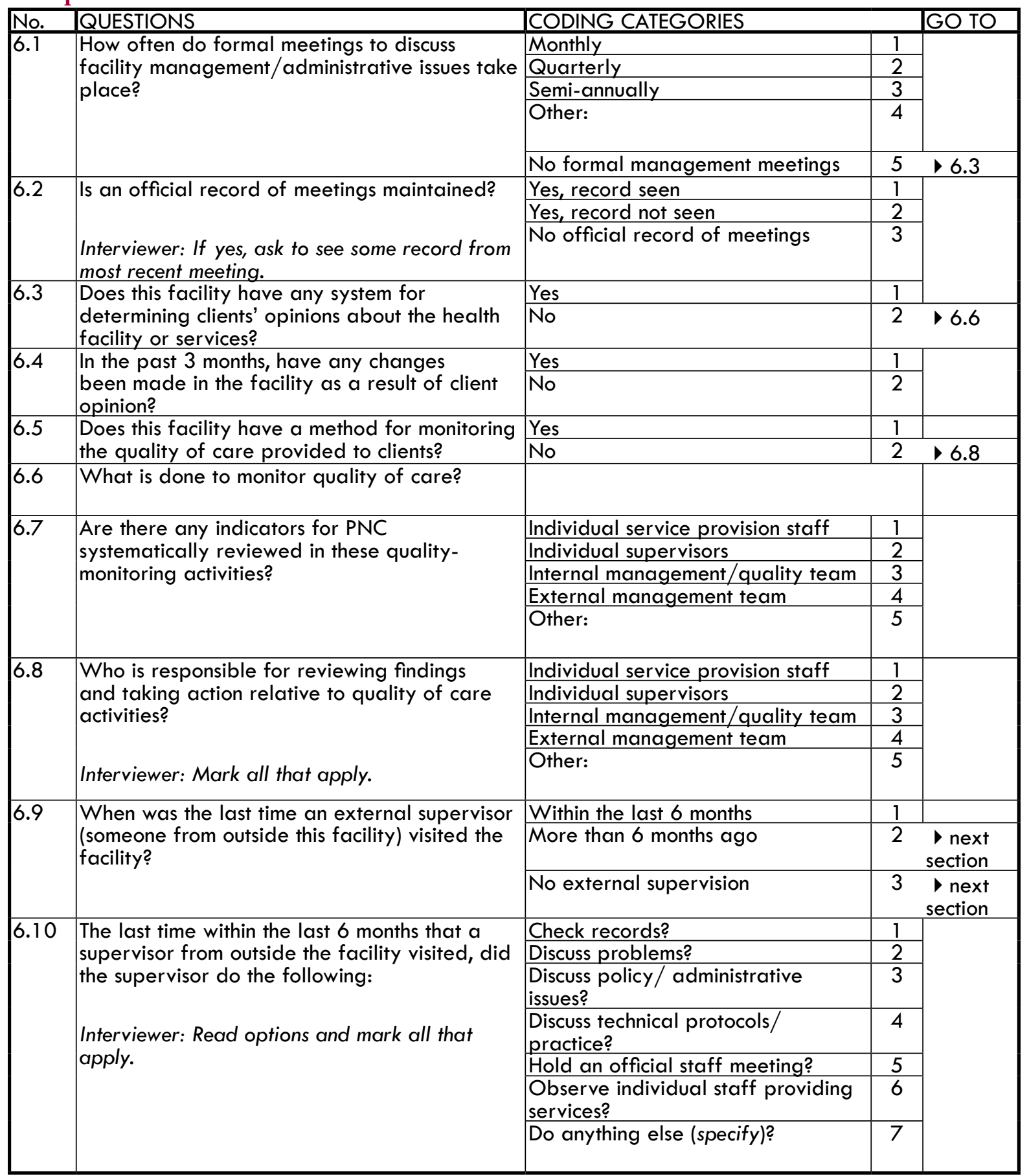


7. PNC quality

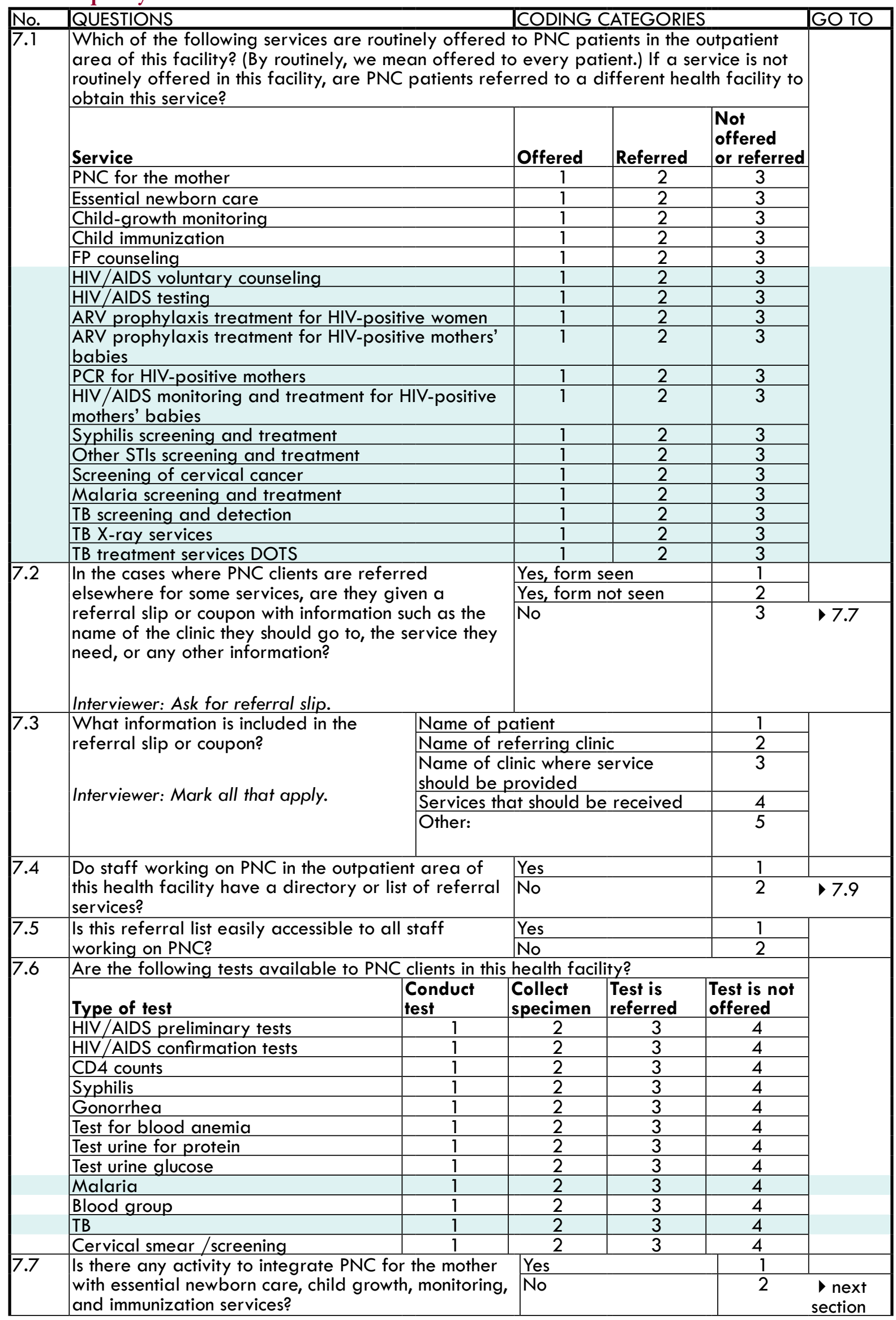


\begin{tabular}{l|l}
7.8 & Please explain the procedure to integrate PNC for
\end{tabular} the mother with essential newborn care, child growth, monitoring, and immunization services.

\section{General infrastructure of the facility}

\begin{tabular}{|c|c|c|c|}
\hline \multirow{10}{*}{$\begin{array}{ll}\text { No. } \\
8.1\end{array}$} & QUESTIONS & \multicolumn{2}{|c|}{ CODING CATEGORIES } \\
\hline & $\begin{array}{l}\text { Interviewer: Observe the conditions and infrastructure in } \\
\text { the facility and mark whether it has the following. }\end{array}$ & Yes & No \\
\hline & Piped running water & 1 & 2 \\
\hline & Electricity & 1 & 2 \\
\hline & Working latrines/toilets for clients & 1 & 2 \\
\hline & Working phone/short wave radio & 1 & 2 \\
\hline & $\begin{array}{l}\text { Transport vehicle or standing arrangements for transport } \\
\text { in the case of emergencies }\end{array}$ & 1 & 2 \\
\hline & $\begin{array}{l}\text { Clean facilities (e.g., the floors are swept, there is no } \\
\text { dust in the desks, etc.) }\end{array}$ & 1 & 2 \\
\hline & Enough chairs or benches in waiting areas & 1 & 2 \\
\hline & $\begin{array}{l}\text { Waiting area for clients where they are protected from } \\
\text { the sun, rain, and snow }\end{array}$ & 1 & 2 \\
\hline
\end{tabular}

9. PNC counseling and examination rooms, equipment, and job aids

\begin{tabular}{|l|l|}
\hline No. QUESTIONS & CODING CATEGORIES \\
\hline
\end{tabular}

Interviewer: Ask to see the room where examinations for postpartum clients are conducted. For the following items, check whether the item is in the room where the examination is conducted or in an adjacent room.

\begin{tabular}{|c|c|c|c|c|c|}
\hline 9.1 & Describe the setting for the & Private room & & & 1 \\
\hline & examination room. & Room with othe & people with separat & g barrier & 2 \\
\hline & & Room with othe & people and no visua & parrier & 3 \\
\hline 9.2 & $\begin{array}{l}\text { Materials and equipment re } \\
\text { washing: }\end{array}$ & for hand & Yes & No & \\
\hline & 1) Clean water supply & & 1 & & 2 \\
\hline & 2) Soap & & 1 & & 2 \\
\hline & 3) Nail brush or stick & & 1 & & 2 \\
\hline & 4) Clean towels & & 1 & & 2 \\
\hline 9.3 & $\begin{array}{l}\text { Materials and equipment re } \\
\text { services in working order: }\end{array}$ & to provide PNC & Yes & No & \\
\hline & $\begin{array}{l}\text { 1) Spot light source (flashlig } \\
\text { accepted) }\end{array}$ & amination light & 1 & & 2 \\
\hline & 2) Examination couch for gy & ical exam & 1 & & 2 \\
\hline & 3) Adults weighing scale & & 1 & & 2 \\
\hline & 4) Infant weighing scale & & 1 & & 2 \\
\hline & 5) Blood pressure gauge & & 1 & & 2 \\
\hline & 6) Stethoscope & & 1 & & 2 \\
\hline & 7) Body thermometer & & 1 & & 2 \\
\hline 9.4 & What is the most commonly & ethod to & Boiling & & 1 \\
\hline & sterilize/disinfect the specu & & Autoclave & & 2 \\
\hline & & & Heat sterilizer & & 3 \\
\hline & & & Use disposable only & & 4 \\
\hline & & & Using bleach & & 5 \\
\hline & & & Other: & & 6 \\
\hline
\end{tabular}


10. IEC materials

\begin{tabular}{|c|c|c|c|}
\hline No. & QQUESTIONS & ICODINC & EGORIES \\
\hline$a r$ & ewer: Verify that & minc & oom. \\
\hline 10.1 & Visual aids for teaching about: & Yes & No \\
\hline & 1) Different FP methods & 1 & 2 \\
\hline & 2) STIs & 1 & 2 \\
\hline & 3) HIV/AIDS & 1 & 2 \\
\hline & 4) PMTCTof HIV & 1 & 2 \\
\hline & 5) Model for demonstrating condom use & 1 & 2 \\
\hline & 6) PNC & 1 & 2 \\
\hline & 7) Newborn care & 1 & 2 \\
\hline & 8) Breastfeeding & 1 & 2 \\
\hline & $\begin{array}{l}\text { 9) Danger signs of complications in the postnatal period for the } \\
\text { mother }\end{array}$ & 1 & 2 \\
\hline & $\begin{array}{l}\text { 10) Danger signs of complications in the postnatal period for the } \\
\text { newborn }\end{array}$ & 1 & 2 \\
\hline 10.2 & Information booklets/leaflets for clients to take home: & Yes & No \\
\hline & 1) On PNC & 1 & 2 \\
\hline & 2) On child care & 1 & 2 \\
\hline & 3) On FP & 1 & 2 \\
\hline & 4) On PMTCT of HIV & 1 & 2 \\
\hline
\end{tabular}

11. Drugs, vitamins, vaccines, and reagents

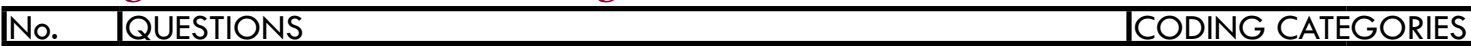

Interviewer: Ask to see where the following drugs/contraceptives/reagents are kept and mark, for each of them, whether it is available on the day of your visit.

\begin{tabular}{|c|c|c|}
\hline Drugs and vitamins for PNC: & Yes & No \\
\hline 1) Oxytocin & 1 & 2 \\
\hline 2) Ergometrine & 1 & 2 \\
\hline 3) Magnesium sulphate & 1 & 2 \\
\hline 4) Calcium gluconate & 1 & 2 \\
\hline 5) Diazepam & 1 & 2 \\
\hline 6) Hydralazine & 1 & 2 \\
\hline 7) Ampicilin & 1 & 2 \\
\hline 8) Gentamicin & 1 & 2 \\
\hline 9) Metronidazole & 1 & 2 \\
\hline 10) Benzathine penicillin & 1 & 2 \\
\hline 11) Cloxacillin & 1 & 2 \\
\hline 12) Amoxycillin & 1 & 2 \\
\hline 13) Ceftriaxone & 1 & 2 \\
\hline 14) Trimethoprim+sulfamethoxazole & 1 & 2 \\
\hline 15) Clotrimazole vaginal pessary & 1 & 2 \\
\hline 16) Erythromycin & 1 & 2 \\
\hline 17) Ciprofloxacin & 1 & 2 \\
\hline 18) Tetracycline or doxycycline & 1 & 2 \\
\hline 19) Arthemether or quinine & 1 & 2 \\
\hline 20) Chloroquine tablet & 1 & 2 \\
\hline 21) Lignocaine & 1 & 2 \\
\hline 22) Adrenaline & 1 & 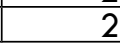 \\
\hline 23) Ringer lactate & 1 & 2 \\
\hline 24) Normal saline $0.9 \%$ & 1 & 2 \\
\hline 25) Glucose $50 \%$ solution & 1 & 2 \\
\hline 26) Water for injection & 1 & 2 \\
\hline 27) Paracetamol & 1 & 2 \\
\hline 28) Gentian violet & 1 & 2 \\
\hline 29) Iron/folic acid tablets & 1 & 2 \\
\hline 30) Mebendazole & 1 & 2 \\
\hline 31) Sulphadoxine+pyrimethamine & 1 & 2 \\
\hline 32) Ferrous sulphate tabs & 1 & 2 \\
\hline 33) Vitamin A & 1 & 2 \\
\hline 34) Lexoprenaline & 1 & 2 \\
\hline
\end{tabular}




\begin{tabular}{|c|c|c|c|}
\hline \multirow[t]{11}{*}{11.2} & Vaccines: & Yes & No \\
\hline & 1) Tetanus toxoid injection & 1 & 2 \\
\hline & 2) Tetanus antitoxin (antitetanus immunoglobulan: human) & 1 & 2 \\
\hline & 3) Combout & 1 & 2 \\
\hline & 4) BCG (TB) & 1 & 2 \\
\hline & 5) OPV (Polio) & 1 & 2 \\
\hline & 6) Measles & 1 & 2 \\
\hline & 7) DPT (Diphetheria Pertussis Tetanus) & 1 & 2 \\
\hline & 8) $\mathrm{HIB}$ & 1 & 2 \\
\hline & 9) HBV (Hepititis B Virus) & 1 & 2 \\
\hline & 10) DT & 1 & 2 \\
\hline \multirow[t]{7}{*}{11.3} & STIs: & Yes & No \\
\hline & 1) Erythromycin & 1 & 2 \\
\hline & 2) Ciprobay & 1 & 2 \\
\hline & 3) Flagyl & 1 & 2 \\
\hline & 4) Metronidazole & 1 & 2 \\
\hline & 5) Benzathine Penicillin & 1 & 2 \\
\hline & 6) Doxycycline & 1 & 2 \\
\hline \multirow[t]{20}{*}{11.4} & ARV drugs: & Yes & No \\
\hline & 1) Nevirapine (NVP) for adults & 1 & 2 \\
\hline & $\begin{array}{l}\text { 2) Azidothymidine (AZT or ZDV) (Also known as Zidovudine or } \\
\text { Retrovir) for adults }\end{array}$ & 1 & 2 \\
\hline & 3) Nevirapine (NVP) for infants & 1 & 2 \\
\hline & 4) AZT or ZDV for infants (syrup) & 1 & 2 \\
\hline & 5) Lamivudine (3TC) & 1 & 2 \\
\hline & 6) Efavirenz (EFV) & 1 & 2 \\
\hline & 7) Zidovudine + Lamivudine (Combivir) & 1 & 2 \\
\hline & 8) Abacavir (ABC) & 1 & 2 \\
\hline & 9) Stavudine (d4T) & 1 & 2 \\
\hline & 10) Emtricitabine (FTC) & 1 & 2 \\
\hline & 11) Atazanavir/ritonavir (ATV/r) & 1 & 2 \\
\hline & 12) Didanosine (ddl) & 1 & 2 \\
\hline & 13) Fosamprenavir/ritonavir (fos-APV/r) & 1 & 2 \\
\hline & 14) Indinavir (IDV) & 1 & 2 \\
\hline & 15) Lopinavir/ritonavir (LPV/r) & 1 & 2 \\
\hline & 16) Nelfinavir (NFV) & 1 & 2 \\
\hline & 17) Rifampicin (RIF) & 1 & 2 \\
\hline & 18) Saquinavir/ritonavir (SQV/r) & 1 & 2 \\
\hline & 19) Tenofovir (TDF) & 1 & 2 \\
\hline \multirow[t]{7}{*}{11.5} & Tuberculosis: & Yes & No \\
\hline & 1) H-Isoniazid & 1 & 2 \\
\hline & 2) R-Rifampicin & 1 & 2 \\
\hline & 3) Z-Pyrazinamide & 1 & 2 \\
\hline & 4) E-Ethambutol & 1 & 2 \\
\hline & 5) S-Streptomycin & 1 & 2 \\
\hline & 6) Contrimoxazale & 1 & 2 \\
\hline \multirow[t]{8}{*}{11.6} & Reagents for tests: & Yes & No \\
\hline & 1) Urine strips & 1 & 2 \\
\hline & 2) Container for catching urine & 1 & 2 \\
\hline & 3) PRP testing kits & 1 & 2 \\
\hline & 4) Proteinuria sticks & 1 & 2 \\
\hline & 5) HIV testing kits & 1 & 2 \\
\hline & 6) Hemoglobin testing kits & 1 & 2 \\
\hline & 7) Reagents for TB test & 1 & 2 \\
\hline
\end{tabular}


12. Record keeping

\begin{tabular}{|c|c|c|c|c|c|}
\hline No. & QUESTIONS & & CODING & GORIES & \\
\hline 12.1 & $\begin{array}{l}\text { Is the following information recorded in the clir } \\
\text { clients? }\end{array}$ & ical history of PNC & Yes & No & \\
\hline & Client's name & & 1 & 2 & \\
\hline & Date of last PNC visit & & 1 & 2 & \\
\hline & Baby's age at last PNC visit & & 1 & 2 & \\
\hline & Whether client has received FP counseling & & 1 & 2 & \\
\hline & Whether client has received FP method & & 1 & 2 & \\
\hline & Whether client has received HIV/AIDS counsel & ing & 1 & 2 & \\
\hline & Whether client has been tested for HIV/AIDS & & 1 & 2 & \\
\hline & Risk factors & & 1 & 2 & \\
\hline & Date of future PNC visit & & 1 & 2 & \\
\hline 12.2 & Is there a record where information on the & Yes & & & 1 \\
\hline & health of the newborn is recorded? & No & & & 2 \\
\hline 12.3 & Is there a record where information on baby's & Yes & & & 1 \\
\hline & immunizations is recorded? & No & & & 2 \\
\hline
\end{tabular}

\section{Service statistics}

\begin{tabular}{|c|c|c|c|c|c|}
\hline \multicolumn{6}{|c|}{ QUESTIONS } \\
\hline \multicolumn{2}{|c|}{$\begin{array}{l}\text { Interviewer: Obtain the following information from the service } \\
\text { statistics. }\end{array}$} & $\begin{array}{l}\text { Last } 12 \\
\text { months }\end{array}$ & $\begin{array}{l}\text { Last } 6 \\
\text { months }\end{array}$ & $\begin{array}{l}\text { Last } \\
\text { month }\end{array}$ & $\begin{array}{l}\text { Info not } \\
\text { available }\end{array}$ \\
\hline \multirow[t]{6}{*}{13.1} & General information on PNC clients: & & & & \\
\hline & $\begin{array}{l}\text { 1) Number of women who attended PNC in the first } \\
\text { week after delivery }\end{array}$ & & & & \\
\hline & $\begin{array}{l}\text { 2) Number of women who attended PNC } 6 \text { weeks after } \\
\text { delivery }\end{array}$ & & & & \\
\hline & $\begin{array}{l}\text { 3) Number of HIV-positive women who attended PNC in } \\
\text { the first week after delivery }\end{array}$ & & & & \\
\hline & $\begin{array}{l}\text { 4) Number of HIV-positive women who attended PNC } 2 \\
\text { weeks after delivery }\end{array}$ & & & & \\
\hline & $\begin{array}{l}\text { 5) Number of HIV-positive women who attended PNC } 6 \\
\text { weeks after delivery }\end{array}$ & & & & \\
\hline \multirow[t]{3}{*}{13.2} & PNC clients who delivered at home: & & & & \\
\hline & $\begin{array}{l}\text { 1) Number of women who delivered at home and } \\
\text { attended PNC in the first week after delivery }\end{array}$ & & & & \\
\hline & $\begin{array}{l}\text { 2) Number of women who delivered at home and } \\
\text { attended PNC } 6 \text { weeks after delivery }\end{array}$ & & & & \\
\hline \multirow[t]{7}{*}{13.3} & PMTCT of HIV: & & & & \\
\hline & $\begin{array}{l}\text { 1) Number of HIV-positive PNC women with CD4 counts } \\
\text { below } 200\end{array}$ & & & & \\
\hline & $\begin{array}{l}\text { 2) Number of HIV-positive PNC women referred for } \\
\text { follow-up care }\end{array}$ & & & & \\
\hline & $\begin{array}{l}\text { 3) Number of babies from HIV-positive women who took } \\
\text { the HIV test using PCR }\end{array}$ & & & & \\
\hline & $\begin{array}{l}\text { 4) Number of babies from HIV-positive women who are } \\
\text { also HIV positive }\end{array}$ & & & & \\
\hline & $\begin{array}{l}\text { 5) Number of HIV-exposed infants started on } \\
\text { cotrimoxazole at } 4 \text { weeks }\end{array}$ & & & & \\
\hline & $\begin{array}{l}\text { 6) Number of infants given follow-up appointments after } \\
\text { cotrimoxazole prophylaxis started }\end{array}$ & & & & \\
\hline
\end{tabular}




\section{Costs}

\begin{tabular}{|c|c|c|c|c|c|}
\hline \multicolumn{6}{|c|}{ QUESTIONS } \\
\hline \multicolumn{6}{|c|}{ Interviewer: Ask questions 14.1 to 14.3 and register answers in the table below. } \\
\hline 14.1 & \multicolumn{5}{|c|}{$\begin{array}{l}\text { What are outpatient clients charged for obtaining the following services, commodities, tests, or } \\
\text { procedures? }\end{array}$} \\
\hline 14.2 & \multicolumn{5}{|c|}{ Is there a waiver or exemption policy for women who cannot pay? } \\
\hline 14.3 & \multicolumn{5}{|c|}{ Who is exempted from paying these fees? } \\
\hline \multirow{2}{*}{\multicolumn{2}{|c|}{ Service or commodity }} & \multirow[t]{2}{*}{$\begin{array}{l}\text { 14.1 Charge in } \\
\text { local currency }\end{array}$} & \multicolumn{2}{|c|}{$\begin{array}{l}14.2 \text { Is there a waiver or } \\
\text { exemption policy? }\end{array}$} & \multirow[t]{2}{*}{$\begin{array}{l}\text { 14.3 Who is } \\
\text { exempted from } \\
\text { paying these fees? }\end{array}$} \\
\hline & & & Yes & No & \\
\hline \multicolumn{2}{|c|}{ PNC consultation } & $\$$ & 1 & 2 & \\
\hline \multicolumn{2}{|c|}{ FP counseling } & $\$$ & 1 & 2 & \\
\hline \multicolumn{2}{|c|}{ Combined oral contraceptives } & $\$$ & 1 & 2 & \\
\hline \multicolumn{2}{|c|}{ Minipills (progestin-only pills) } & $\$$ & 1 & 2 & \\
\hline \multicolumn{2}{|c|}{ Emergency contraceptive pills } & $\$$ & 1 & 2 & \\
\hline \multicolumn{2}{|c|}{$\begin{array}{l}\text { Progestin-only injectables (injection every } \\
2 \text { or } 3 \text { months) }\end{array}$} & $\$$ & 1 & 2 & \\
\hline \multicolumn{2}{|c|}{ Monthly injectables } & $\$$ & 1 & 2 & \\
\hline \multicolumn{2}{|c|}{ Combined patches } & $\$$ & 1 & 2 & \\
\hline \multicolumn{2}{|c|}{ Combined vaginal rings } & $\$$ & 1 & 2 & \\
\hline \multicolumn{2}{|c|}{ Jadelle implants } & $\$$ & 1 & 2 & \\
\hline \multicolumn{2}{|c|}{ Implanon implants } & $\$$ & 1 & 2 & \\
\hline \multicolumn{2}{|c|}{ Sinoplan (II) implants } & $\$$ & 1 & 2 & \\
\hline \multicolumn{2}{|c|}{ IUD } & $\$$ & 1 & 2 & \\
\hline \multicolumn{2}{|l|}{ IUS } & $\$$ & 1 & 2 & \\
\hline \multicolumn{2}{|c|}{ Male condoms } & $\$$ & 1 & 2 & \\
\hline \multicolumn{2}{|c|}{ Female condoms } & $\$$ & 1 & 2 & \\
\hline \multicolumn{2}{|c|}{ Diaphragms } & $\$$ & 1 & 2 & \\
\hline \multicolumn{2}{|c|}{ Spermicides } & $\$$ & 1 & 2 & \\
\hline \multicolumn{2}{|c|}{ Cervical caps } & $\$$ & 1 & 2 & \\
\hline \multicolumn{2}{|c|}{ Female sterilization } & $\$$ & 1 & 2 & \\
\hline \multicolumn{2}{|c|}{ Vasectomy } & $\$$ & 1 & 2 & \\
\hline \multicolumn{2}{|c|}{ HIV/AIDS testing } & $\$$ & 1 & 2 & \\
\hline Syphi & testing & $\$$ & 1 & 2 & \\
\hline Other & TI testing & $\$$ & 1 & 2 & \\
\hline
\end{tabular}




\section{B. Observation guide}

\section{INSTRUCTIONSTO DATA}

COLLECTOR: Before proceeding to observe the interaction between client and provider, use the greeting below to explain to the provider that you will be observing her/him while s/he attends to his/her clients and to make sure that she/he knows that you are not there to evaluate her/him and that you are not an "expert" who can be consulted during the session. Then obtain the client's informed consent. When observing, be as discreet as possible. Try to sit so that you are behind the client but not directly in view of the provider, and make notes quickly. For each question, describe or circle the code of the response that most appropriately represents your observation of what happened during the interaction. As discussed during the training, you may witness behavior that poses a serious risk to the client's health. Please keep in mind the guidelines for when to intervene in the consultation on behalf of the client's welfare.

\section{GREETING FOR THE PROVIDER: My} name is and I work with , where we are conducting a study

to see what information clients are given during their postnatal care visits. This information will help us to propose ways in which to improve the services offered. As a part of this study, we are observing the interaction of health providers and their clients during postnatal care visits. I will observe silently as you attend to your clients and take notes. I am in no way an expert in your area, and I am not here to evaluate your work. I will not make any comments or interfere in your consultations in any way.

Your participation in this component of the study will remain confidential. I will not record your name in the notes I take. This way, no one will be able to know that I observed your appointments. Do I have your permission?
INFORMED CONSENT FROMTHE CLIENT: My name is_ and I work with , where we are conducting a study to see what information clients are given during their postnatal visits. This information will help us to propose ways in which to improve the services offered. As a part of this study we are observing the interaction of health providers and their clients during postnatal visits. I would appreciate it if you allowed me to observe your appointment today. If you do, I will be accompanying you through your visit and seeing what you and your provider talk about. I will also observe when he examines you. I am not a health provider in this facility and will not making any comments or participating in your consultations in any way. At the end of your visit, I will, if you allow me to, ask you some questions regarding your experience during your visit. This interview will be private, and none of the providers that see you today will be present.

However, your participation in this study is voluntary and you can choose not to let me accompany you or to answer to my questions. If you choose not to participate in either component of the study, you will not be penalized in any way. If you accept to participate and you change your opinion later, you can also ask me to exit the room whenever you want.

If you participate, you will not receive money or gifts and you will not benefit directly from your participation. However, your participation will result in improved future maternal and reproductive health services. Your participation in this study will remain confidential. I will not record your name in the notes I take. This way, no one will be able to know that I observed your appointments.

Finally, if you have any questions about this study at a later stage, you can come back here and clear your doubts with your provider at the clinic. Do you accept to participate in this study? 
1. Facility identification

\begin{tabular}{|c|c|c|c|}
\hline \multirow{2}{*}{\begin{tabular}{|l} 
No. \\
1.1
\end{tabular}} & \multirow{2}{*}{$\begin{array}{l}\text { QUESTIONS } \\
\text { Date of observations }\end{array}$} & \multicolumn{2}{|l|}{ CODING CATEGORIES } \\
\hline & & $\overline{\text { (Day / Month/ Year) }}$ & \\
\hline 1.2 & Facility name & & \\
\hline 1.3 & City or locality & & \\
\hline \multirow[t]{7}{*}{1.4} & Type of facility & Hospital & 1 \\
\hline & & Health center with maternity ward & 2 \\
\hline & & Health center without maternity ward & 3 \\
\hline & & Health post with maternity ward & 4 \\
\hline & & Health post without maternity ward & 5 \\
\hline & & Dispensary & 6 \\
\hline & & Other: & 7 \\
\hline \multirow[t]{4}{*}{1.5} & Type of sector & Government & 1 \\
\hline & & NGO & 2 \\
\hline & & Private & 3 \\
\hline & & Other: & 4 \\
\hline \multirow[t]{4}{*}{1.6} & Result of the observation & Complete & 1 \\
\hline & & Incomplete & 2 \\
\hline & & Refused & 3 \\
\hline & & Other: & 4 \\
\hline
\end{tabular}

\section{Integration of PNC and FP services}

No. QUESTIONS CODING CATEGORIES

Interviewer: Observe the client-provider interaction during

the PNC visit and note whether providers do the following.

2.1 Discuss return to fertility.

2.2 Ask about resumption of sexual activity.

2.3 Ask whether client wants more children in the future.

2.4 Ask about current FP use.

2.5 Interviewer: Mark whether client is using an FP method.

2.6 Interviewer: Mark which FP method

the client is using.

Yes

No

Combined oral contraceptives

Minipills (progestin-only pills)

Emergency contraceptive pills

Progestin-only injectables (injection every 2 or

3 months)

Monthly injectables

Combined patches

Combined vaginal rings

Jadelle implants

Implanon implants

Sinoplant (II) implants

IUD

IUS

Male condoms

Female condoms

Diaphragms

Spermicides

Cervical caps

Female sterilization

Vasectomy

Fertility awareness methods

Withdrawal

LAM

Other:

\begin{tabular}{|l|r|}
\hline & \\
& No \\
& 2 \\
& 2 \\
& 2 \\
& 2 \\
\hline
\end{tabular}

\begin{tabular}{l|}
2 \\
2 \\
2 \\
2 \\
1 \\
\hline 2
\end{tabular}

$+2$ 


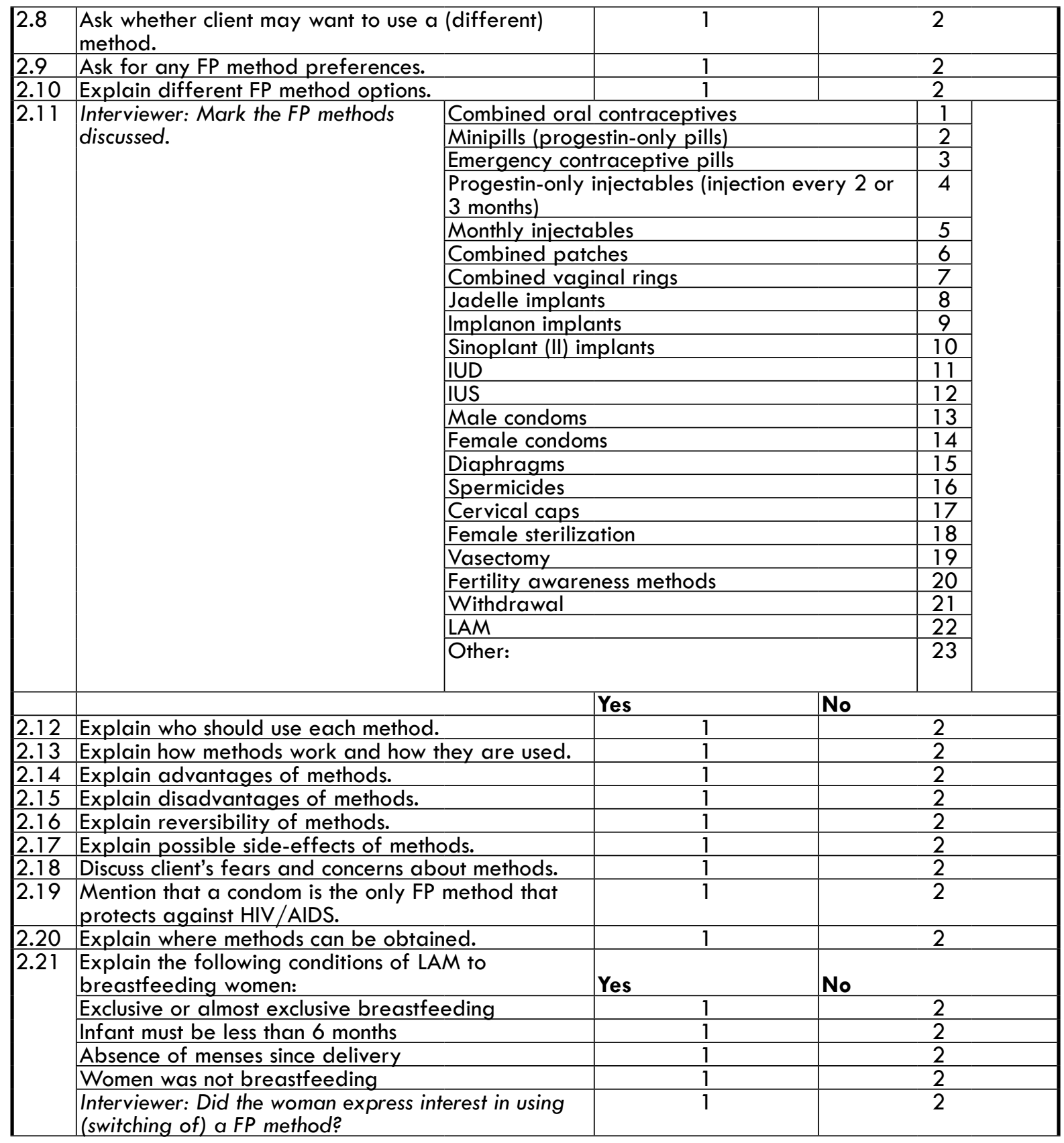




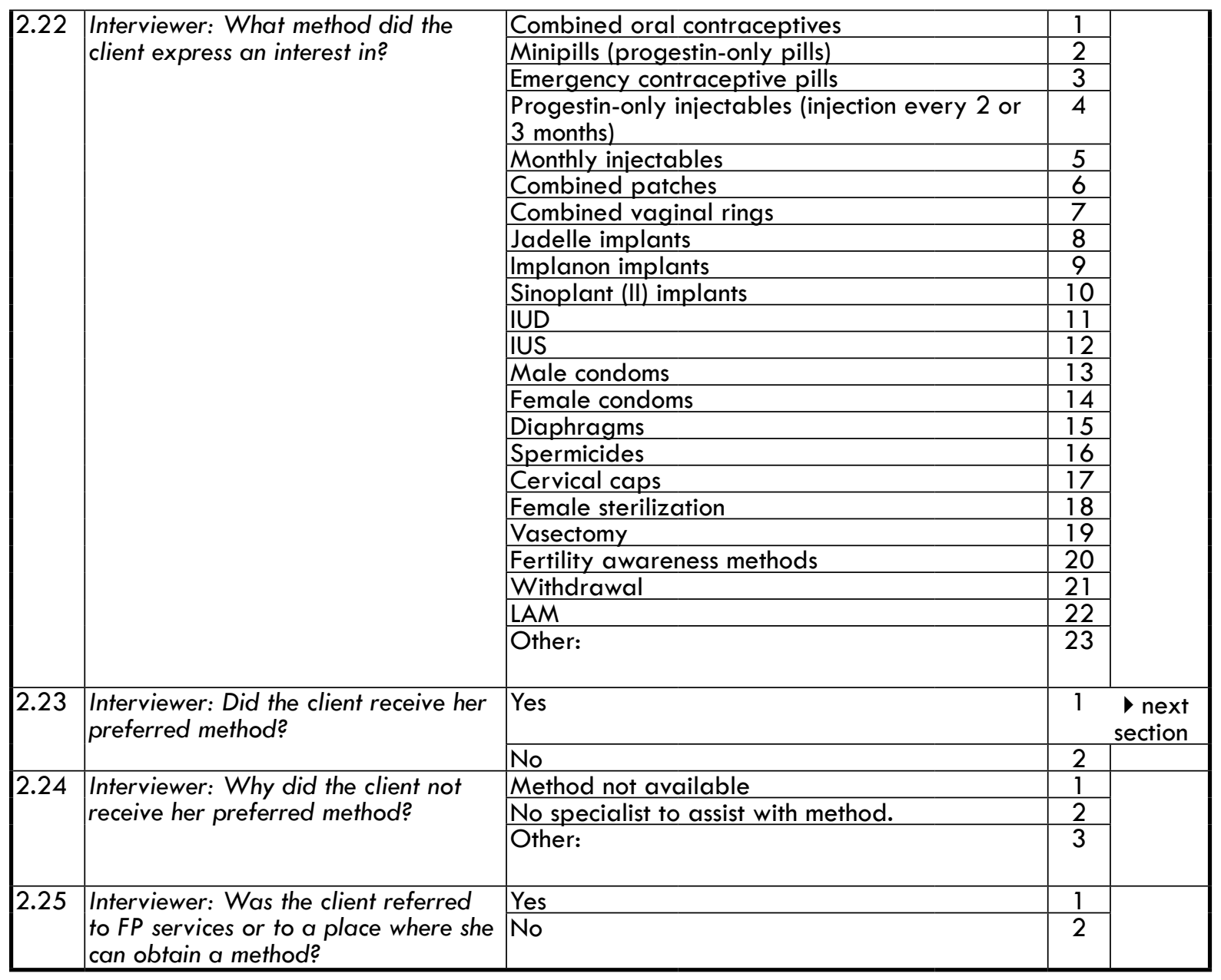

\section{Introduction and clinical history}

\begin{tabular}{|l|l|l|}
\hline No. & QUESTIONS & CODING CATEGORIES \\
\hline
\end{tabular}

Introduction

$3.1 \quad$ Greet client.

3.2 Introduce yourself to the client.

3.3 Tell the client what is going to be done and encourage her to ask questions.

Clinical history

3.4 Ask age of client.

3.5 Ask age of baby.

3.6 Ask date of last menstrual period.

3.7 Ask history of hypertension.

3.8 Ask history of diabetes.

3.9 Ask about alcohol use and smoking.

3.10 Ask about HIV status.

3.11 Ask about TB history.

3.12 Ask about general health problems.

3.13 Ask about medication currently taken.

Recent birth history

3.14 Ask number of prior pregnancies and births.

3.15 Ask place of delivery.

3.16 Ask mode of delivery.

3.17 Ask duration of labor.

3.18 Ask whether client had heavy bleeding during or after delivery with a previous pregnancy.

3.19 Ask whether placenta was delivered normally or retained.

3.20 Ask whether baby cried soon after birth.

3.21 Ask whether client has received a dose of Vitamin A since delivery.

\begin{tabular}{|c|c|}
\hline Yes & No \\
\hline 1 & 2 \\
\hline 1 & 2 \\
\hline 1 & 2 \\
\hline Yes & No \\
\hline 1 & 2 \\
\hline 1 & 2 \\
\hline 1 & 2 \\
\hline 1 & 2 \\
\hline 1 & 2 \\
\hline 1 & 2 \\
\hline 1 & 2 \\
\hline 1 & 2 \\
\hline 1 & 2 \\
\hline 1 & 2 \\
\hline Yes & No \\
\hline 1 & 2 \\
\hline 1 & 2 \\
\hline 1 & 2 \\
\hline 1 & 2 \\
\hline 1 & 2 \\
\hline 1 & 2 \\
\hline 1 & 2 \\
\hline 1 & 2 \\
\hline
\end{tabular}




\begin{tabular}{|c|c|c|c|}
\hline \multirow{2}{*}{\multicolumn{2}{|c|}{\begin{tabular}{|l|l|}
3.22 & Ask how many TT doses client had received. \\
Danger signs in postnatal period
\end{tabular}}} & \multirow{3}{*}{$\begin{array}{|ll|} & 1 \\
\text { Yes } & \\
& 1\end{array}$} & \multirow{3}{*}{\begin{tabular}{|ll} 
& 2 \\
No & \\
& 2
\end{tabular}} \\
\hline & & & \\
\hline 3.23 & $\begin{array}{l}\text { The provider asked the woman whether she has experienced } \\
\text { any problems since delivery (e.g., convulsions, difficulty } \\
\text { breathing, fever, abdominal pain, swollen breasts, foul-smelling } \\
\text { lochia, bleeding or pus from C-section or episiotomy scar/ } \\
\text { perineum, or headache). }\end{array}$ & & \\
\hline \multicolumn{2}{|r|}{ Danger signs in the newborn } & Yes & No \\
\hline 3.24 & $\begin{array}{l}\text { The provider asked the woman whether her baby has } \\
\text { experienced any problems since birth (e.g., difficult breathing, } \\
\text { convulsions, fever, bleeding, diarrhea, difficulty feeding, skin } \\
\text { pustules, yellow skin or eyes, blue skin, tongue, or lips, or pus in } \\
\text { the cord stump). }\end{array}$ & 1 & 2 \\
\hline \multicolumn{2}{|r|}{ Screening for TB } & Yes & No \\
\hline 3.25 & $\begin{array}{l}\text { Ask about persistent cough for } 3 \text { or more weeks with or without } \\
\text { blood-stained sputum }\end{array}$ & 1 & 2 \\
\hline 3.26 & Ask about chest pain. & 1 & 2 \\
\hline 3.27 & Ask about close contact with a case of TB. & 1 & 2 \\
\hline 3.28 & Ask about loss of body weight in past month. & 1 & 2 \\
\hline 3.29 & Ask about intermittent fever for more than 2 weeks. & 1 & 2 \\
\hline 3.30 & Ask about night sweats for more than 2 weeks. & 1 & 2 \\
\hline 3.31 & Ask whether the baby ever had a BGG immunization. & 1 & 2 \\
\hline 3.32 & Explore signs and symptoms of other opportunistic infections. & 1 & 2 \\
\hline
\end{tabular}

4. Physical exam

\begin{tabular}{|c|c|c|c|}
\hline No. & QUESTIONS & CODING CATEGOR & \\
\hline & & Yes & No \\
\hline 4.1 & Wash hands before examining client. & $\begin{array}{l}\text { a) With water only } \\
\text { b) Water and soap } \\
\text { c) With antiseptic } \\
\text { d) Other: }\end{array}$ & 2 \\
\hline 4.2 & Take weight. & 1 & 2 \\
\hline 4.3 & Check height. & 1 & 2 \\
\hline 4.4 & Take blood pressure. & 1 & 2 \\
\hline 4.5 & Take temperature. & 1 & 2 \\
\hline 4.6 & Examine hands and eyes for pallor. & 1 & 2 \\
\hline 4.7 & Conduct breast exam. & 1 & 2 \\
\hline 4.8 & Palpate abdomen for uterine involution. & 1 & 2 \\
\hline 4.9 & Check for any enlarged lymph nodes (TB). & 1 & 2 \\
\hline Pelvi & examination & Yes & No \\
\hline 4.10 & Conduct pelvic examination. & 1 & 2 \\
\hline If pe & jic examination was performed, did the provider: & Yes & No \\
\hline 4.11 & Wash her hands before the exam? & $\begin{array}{l}\text { a) With water only } \\
\text { b) Water and soap } \\
\text { c) With antiseptic } \\
\text { d) Other: }\end{array}$ & 2 \\
\hline 4.12 & Put on new or disinfected gloves before the exam? & 1 & 2 \\
\hline 4.13 & Use sterilized or disinfected instruments? & 1 & 2 \\
\hline
\end{tabular}

5. Vitamins and nutritional supplements

\begin{tabular}{|l|l|l|l|}
\hline No. & QUESTIONS & CODING CATEGORIES \\
\hline Iron and folic acid & Yes & No \\
\hline 5.1 & Prescribe/give iron/folic acid. & $\begin{array}{l}\text { a. Prescribe } \\
\text { b. Give }\end{array}$ & 2 \\
\hline 5.2 & Explain purpose of iron tablets. & 1 & 2 \\
\hline 5.3 & Explain how to take iron tables. & 1 & 2 \\
\hline Vitamin A & Yes & No \\
\hline 5.4 & Assess need (ask if given in delivery). & \multicolumn{1}{|c|}{1} \\
\hline 5.5 & Prescribe/give vitamin A. & $\begin{array}{l}\text { a. Prescribe } \\
\text { b. Give }\end{array}$ & 2 \\
\hline 5.6 & Explain purpose of vitamin A. & \multicolumn{1}{|c|}{1} & 2 \\
\hline
\end{tabular}


6. Information on PNC and danger signs

No. QUESTIONS

CODING CATEGORIES

Self-care

$6.1 \quad$ Assess nutritional status using Body Mass Index.

6.2 Discuss breast care.

6.3 Advise about diet during breastfeeding.

6.4 Discuss personal hygiene and how to clean the perineum.

Danger signs

Interviewer: Explain that women should return to the facility if they

experience the following.

6.5 Excessive bleeding

6.6 Convulsions or fits

\begin{tabular}{ll}
6.6 & Fever \\
\hline 6.8 & Abdomi \\
\hline
\end{tabular}

6.8 Abdominal pain

6.9 Feels ill

6.10 Swollen, red, or tender breasts or sore nipples

6.11 Urine dribbling or pain/burning sensation while urinating

6.12 Pain in the perineum or draining pus

6.13 Foul-smelling vaginal discharge (lochia)

6.14 Broken episiotomy scar

6.15 Bleeding from C-section scar

6.16 Pus oozing from C-section scar/site

6.17 Excessive tiredness or breathlessness

6.18 Swollen hands, face, legs

6.19 Severe headache or blurred vision

6.20 Pain in the calf muscle (Thrombophlebitis)

6.21 Other:

\begin{tabular}{|c|c|}
\hline Yes & No \\
\hline 1 & 2 \\
\hline 1 & 2 \\
\hline 1 & 2 \\
\hline 1 & 2 \\
\hline Yes & No \\
\hline 1 & 2 \\
\hline 1 & 2 \\
\hline 1 & 2 \\
\hline 1 & 2 \\
\hline 1 & 2 \\
\hline 1 & 2 \\
\hline 1 & 2 \\
\hline 1 & 2 \\
\hline 1 & 2 \\
\hline 1 & 2 \\
\hline 1 & 2 \\
\hline 1 & 2 \\
\hline 1 & 2 \\
\hline 1 & 2 \\
\hline 1 & 2 \\
\hline 1 & 2 \\
\hline 1 & 2 \\
\hline
\end{tabular}

7. Advice on infant feeding

\begin{tabular}{|c|c|c|c|c|c|}
\hline \multirow{3}{*}{\begin{tabular}{|l|} 
No. \\
7.1
\end{tabular}} & \multirow{3}{*}{$\begin{array}{l}\text { QUESTIONS } \\
\text { Give advice or counsel on infant feeding. }\end{array}$} & \multicolumn{3}{|c|}{ CODING CATEGORIES } & GO TO \\
\hline & & \multicolumn{2}{|c|}{ Yes } & 1 & \\
\hline & & \multicolumn{2}{|l|}{ No } & 2 & $\begin{array}{l}\text { next } \\
\text { section }\end{array}$ \\
\hline \multirow[t]{2}{*}{7.2} & \multirow[t]{2}{*}{ Ask which feeding method the mother prefers. } & \multicolumn{2}{|l|}{ Yes } & 1 & \\
\hline & & \multicolumn{2}{|l|}{ No } & 2 & \\
\hline \multirow[t]{4}{*}{7.3} & \multirow[t]{4}{*}{ Interviewer: Record mother's choice. } & \multicolumn{2}{|c|}{ Breastfeeding only } & 1 & \\
\hline & & \multicolumn{2}{|c|}{$\begin{array}{l}\text { Formula } x \text { replacement } \\
\text { feeding only }\end{array}$} & 2 & 7.15 \\
\hline & & \multicolumn{2}{|c|}{ Mix feeding (both) } & 3 & 7.15 \\
\hline & & Yes & No & & \\
\hline 7.4 & Request that the mother demonstrates breastfeeding. & 1 & 2 & & \\
\hline 7.5 & Guide or assist with positioning of mother and baby. & 1 & 2 & & \\
\hline 7.6 & Guide or assist with attachment of the baby to the breast. & 1 & 2 & & \\
\hline 7.7 & Asses how the baby attached and sucked the breast. & 1 & 2 & & \\
\hline 7.8 & $\begin{array}{l}\text { Encourage the mother to discuss how she was managing } \\
\text { with breastfeeding. }\end{array}$ & 1 & 2 & & \\
\hline $\begin{array}{l}\text { Discu } \\
\text { enou }\end{array}$ & $\begin{array}{l}\text { ss the following as symptoms that the baby is getting } \\
\text { gh food during breastfeeding. }\end{array}$ & Yes & No & & \\
\hline 7.9 & Whether baby passes urine 6 times in 24 hours & 1 & 2 & & \\
\hline 7.10 & Whether the mother hears the baby swallow & 1 & 2 & & \\
\hline 7.11 & Breasts feel soft after feedings & 1 & 2 & & \\
\hline 7.12 & Baby gains weight & 1 & 2 & & \\
\hline 7.13 & Baby seems contented & 1 & 2 & & \\
\hline 7.14 & Reemphasize the importance of exclusive breastfeeding. & 1 & 2 & & \\
\hline 7.15 & Talk about risks of mixed feeding. & 1 & 2 & & \\
\hline 7.16 & Discuss hygiene in preparing food. & 1 & 2 & & \\
\hline 7.17 & Discuss correct strength of formula in replacement feeding. & 1 & 2 & & \\
\hline 7.18 & Discuss adequate supply of fuel for replacement feeding. & 1 & 2 & & \\
\hline 7.19 & $\begin{array}{l}\text { Discuss use of boiled water when preparing replacement } \\
\text { feeding. }\end{array}$ & 1 & 2 & & \\
\hline
\end{tabular}


8. Danger signs for the newborn

\begin{tabular}{|c|c|c|c|}
\hline No. & QUESTIONS & CODING & ORIES \\
\hline $\begin{array}{l}\text { Interv } \\
\text { exper }\end{array}$ & $\begin{array}{l}\text { ewer: Explain that the client should bring her baby to the facility if it } \\
\text { ences the following. }\end{array}$ & Yes & No \\
\hline 8.1 & $\begin{array}{l}\text { Difficult breathing (grunting or groaning, chest retractions, flaring } \\
\text { of nostrils, shallow breathing) }\end{array}$ & 1 & 2 \\
\hline 8.2 & Convulsions or fits & 1 & 2 \\
\hline 8.3 & Fever & 1 & 2 \\
\hline 8.4 & Feels cold or cooler than a normal person & 1 & 2 \\
\hline 8.5 & Diarrhea & 1 & 2 \\
\hline 8.6 & Not feeding at all - not sucking & 1 & 2 \\
\hline 8.7 & Difficulty feeding - sucking poorly & 1 & 2 \\
\hline 8.8 & $\begin{array}{l}\text { Cannot be awakened to suck and does not stay awake to suck } \\
\text { long enough }\end{array}$ & 1 & 2 \\
\hline 8.9 & Sucks but does not seem satisfied & 1 & 2 \\
\hline 8.10 & Feeds less than 5 times in 24 hours & 1 & 2 \\
\hline 8.11 & Red swollen eyelids and pus discharging from the eyes & 1 & 2 \\
\hline 8.12 & Skin pustules/rash & 1 & 2 \\
\hline 8.13 & Yellow skin or eyes & 1 & 2 \\
\hline 8.14 & Tongue and lips or skin color is blue & 1 & 2 \\
\hline 8.15 & A cord stump that is red or draining pus & 1 & 2 \\
\hline 8.16 & Less than 6 voidings in 24 hours, not frequent yellow, seedy stools & 1 & 2 \\
\hline 8.17 & Baby is flaccid or rigid. & 1 & 2 \\
\hline 8.18 & Irritable crying/inconsolable & 1 & 2 \\
\hline 8.19 & Other: & 1 & 2 \\
\hline
\end{tabular}

\section{Immunization schedule}

\begin{tabular}{|c|c|c|c|c|c|}
\hline No. & QUESTIONS & \multicolumn{3}{|c|}{ CODING CATEGORIES } & GO TO \\
\hline & & Yes & \multicolumn{2}{|l|}{ No } & \\
\hline 9.1 & $\begin{array}{l}\text { Did the provider give advice about immunizations for the } \\
\text { baby? }\end{array}$ & 1 & \multicolumn{2}{|l|}{2} & \\
\hline 9.2 & $\begin{array}{l}\text { Did the provider check which immunizations the baby had } \\
\text { already received? }\end{array}$ & 1 & \multicolumn{2}{|l|}{2} & \\
\hline \multirow[t]{2}{*}{9.3} & \multirow[t]{2}{*}{ Did the mother agree to the baby receiving immunizations? } & \multicolumn{2}{|l|}{ Yes } & 1 & \\
\hline & & \multicolumn{2}{|l|}{ No } & 2 & $\begin{array}{l}\text { next } \\
\text { section }\end{array}$ \\
\hline \multirow[t]{5}{*}{9.4} & Which immunizations did the baby receive at this visit? & Yes & No & & \\
\hline & Polio & 1 & \multicolumn{2}{|l|}{2} & \\
\hline & BCG & 1 & \multicolumn{2}{|l|}{2} & \\
\hline & HBV & 1 & \multirow{2}{*}{\multicolumn{2}{|c|}{2}} & \\
\hline & Other: & 1 & & & \\
\hline
\end{tabular}

\section{HIV and STIs}

\begin{tabular}{|c|c|c|c|}
\hline No. & QUESTIONS & CODING & DRIES \\
\hline Counse & ling about HIV and STIs & Yes & No \\
\hline 10.1 & Discuss STIs symptoms/signs. & 1 & 2 \\
\hline 10.2 & Discuss effects of STI/HIV/AIDS in the baby & 1 & 2 \\
\hline 10.3 & Ask client about presence of STI/HIV symptoms. & 1 & 2 \\
\hline Discuss & STI/HIV risk factors: & Yes & No \\
\hline 10.4 & Unprotected sex (no condom use) & 1 & 2 \\
\hline 10.5 & Multiple sex partners & 1 & 2 \\
\hline 10.6 & Partner with multiple sex partners & 1 & 2 \\
\hline 10.7 & Intravenous drug use & 1 & 2 \\
\hline 10.8 & Explain that condoms reduce HIV risk. & 1 & 2 \\
\hline 10.9 & Explain that abstinence reduces HIV risk. & 1 & 2 \\
\hline 10.10 & Explain how to use condoms. & 1 & 2 \\
\hline 10.11 & Ask client about their STI/HIV risk factors. & 1 & 2 \\
\hline 10.12 & Provide information on PMTCT of HIV & 1 & 2 \\
\hline 10.13 & Discuss HIV testing. & 1 & 2 \\
\hline 10.14 & Discuss where to go for VCT services. & 1 & 2 \\
\hline 10.15 & Discuss client's interest in getting tested. & 1 & 2 \\
\hline 10.16 & Suggest partner get tested for HIV. & 1 & 2 \\
\hline
\end{tabular}


11. Counseling for HIV-positive women

\begin{tabular}{|l|l|c|c|}
\hline No. & QUESTIONS & \multicolumn{2}{l|}{ CODING CATEGORIES } \\
\hline Interviewer: Mark whether the provider asks any of the following. & Yes & No \\
\hline 11.1 & Client received ARVs after delivery. & 1 & 2 \\
\hline 11.2 & Client is currently taking ARVs. & 1 & 2 \\
\hline 11.3 & Client had a blood test for CD4 count since delivery. & 2 \\
\hline 11.4 & Client has a good appetite. & 1 & 2 \\
\hline 11.5 & Client is experiencing any diarrhea or nausea. & 1 & 2 \\
\hline 11.6 & Client has lost excess weight since childbirth. & 1 & 2 \\
\hline 11.7 & Baby received ARVs after delivery. & 1 & 2 \\
\hline 11.8 & Baby is currently taking ARVs. & 1 & 2 \\
\hline 11.9 & Baby had a blood test for CD4 count since delivery. & 1 & 2 \\
\hline 11.10 & Baby is taking cotrimaxazole prophylaxis. & 1 & 2 \\
\hline 11.11 & Partner's HIV status is established. & 1 & 2 \\
\hline Interviewer: Mark whether the provider did any of the following. & 1 & 2 \\
\hline 11.12 & Informed client about care and support available. & 2 \\
\hline 11.13 & Discussed symptoms of opportunistic infections. & 1 \\
\hline 11.14 & Explained infant feeding AFASS. & 1 & 2 \\
\hline 11.15 & $\begin{array}{l}\text { Explained where she and/or her partner can get psychosocial } \\
\text { support. }\end{array}$ & 1 & 2 \\
\hline 11.16 & Discussed the use of cotrimoxazole prophylaxis for baby. & 1 & 2 \\
\hline 11.17 & Prescribed cotrimoxazole for mother. & & 2 \\
\hline 11.18 & $\begin{array}{l}\text { Advised against unprotected early penetrative sex after } \\
\text { delivery. }\end{array}$ & 1 & 2 \\
\hline
\end{tabular}

12. Laboratory tests

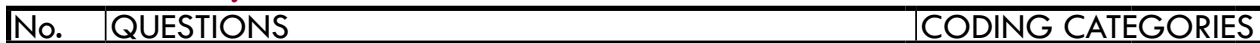

Interviewer: Observe the client-provider interaction during the PNC check-up visit, and check which of the following tests were done on site, for which tests she was referred somewhere else, and which tests were not done at all.

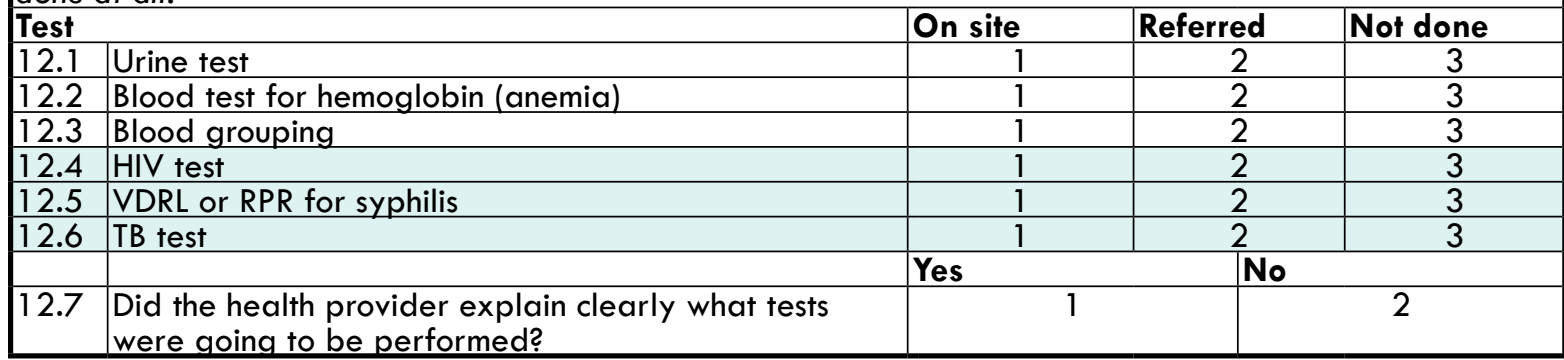

\section{Post-test information on HIV/AIDS}

\section{\begin{tabular}{|l|l|l|l|l|}
\hline No. & QUESTIONS \\
\hline
\end{tabular}}

Interviewer: Observe the client-provider interaction during the PNC check-up visit, once the client has taken the HIV test (if she does), and ask the following questions.

\begin{tabular}{|c|c|c|c|c|c|}
\hline \multirow[t]{3}{*}{13.1} & \multirow{3}{*}{$\begin{array}{l}\text { Did the woman receive her HIV/AIDS results in } \\
\text { privacy, or were there other people with her? If } \\
\text { there were other people, who were they? }\end{array}$} & \multicolumn{3}{|c|}{ Received results alone. } & 1 \\
\hline & & \multicolumn{3}{|c|}{ There were other women with her. } & 2 \\
\hline & & \multicolumn{3}{|c|}{$\begin{array}{l}\text { If there were other people with her, } \\
\text { who? }\end{array}$} & 3 \\
\hline & & & Yes & $\mathbf{N}$ & \\
\hline 13.2 & Did the health provider explain clearly the resul & of the test? & 1 & & 2 \\
\hline 13.3 & $\begin{array}{l}\text { Did the health provider ask the client whether sh } \\
\text { about her results? }\end{array}$ & had any questions & 1 & & 2 \\
\hline 13.4 & $\begin{array}{l}\text { If the results of the HIV test were negative, did t } \\
\text { explain to the client how to protect herself so she } \\
\text { negative? }\end{array}$ & $\begin{array}{l}\text { health provider } \\
\text { remained }\end{array}$ & 1 & & 2 \\
\hline 13.5 & $\begin{array}{l}\text { If the results of the HIV test were positive, did th } \\
\text { explain to the client what she should do to prote } \\
\text { baby from the infection? }\end{array}$ & $\begin{array}{l}\text { health provider } \\
\text { herself and her }\end{array}$ & 1 & & 2 \\
\hline
\end{tabular}


14. Client's demographic information

Interviewer: If you were not able to obtain the following information during the observation, ask the client directly once her consultation is over.

14.1 Age

14.2 Delivery date

14.3 Number of PNC visits, including this one: 


\section{Client exit interview}

\section{INSTRUCTIONS FOR THE}

INTERVIEWER: Approach all women as they leave the area where PNC services are provided, and ask them whether they are willing to be asked some questions about the services they received today. If they accept, make sure that you are in a place that guarantees privacy and where the woman is comfortable. Ask them for their informed consent to be interviewed (read the form below). Interview only women who give their informed consent. For each item in the interview, circle the code of the adequate response or describe, as appropriate.

\section{INFORMED CONSENT FORM FOR} THE CLIENT: My name is and I work with , where we are conducting a study to see what information clients are given during their postnatal care visits. This information will help us to propose ways in which to improve the services offered. As a part of this study, we are interviewing women who had a postnatal care visit today. In these interviews, we ask them about the services and information they obtained, their satisfaction with the services received, their plans for having more children in the future, and other health needs they may have. I would appreciate it if you allowed me to ask you some questions. The interview will be private, and none of the providers that saw you today will be present.

Your participation in this study is voluntary, and you can choose not to let me interview you. If you choose not to participate in our study, you will not be penalized in any way. If you accept to participate and you change your opinion later, you can also ask me to interrupt the interview whenever you want.

If you participate, you will not receive money or gifts, and you will not benefit directly from your participation. However, your participation will result in improved future maternal and reproductive health services.

Your participation in this study will remain confidential. I will not record your name in the questionnaire. This way, no one will be able to know that I observed your appointments.

Finally, if you have any questions about this study at a later stage, you can come back here and clear your doubts with your provider at the clinic. Do you accept to participate in this study? 
1. Facility identification

\begin{tabular}{|c|c|c|c|}
\hline No. & QUESTIONS & \multicolumn{2}{|l|}{ CODING CATEGORIES } \\
\hline 1.1 & Date of interview & \multicolumn{2}{|l|}{ (Day/ Month/ Year) } \\
\hline 1.2 & Facility name & \multicolumn{2}{|l|}{ (Day/ Month/ Year) } \\
\hline 1.3 & City or locality & & \\
\hline \multirow[t]{7}{*}{1.4} & \multirow[t]{7}{*}{ Type of facility } & Hospital & 1 \\
\hline & & Health center with maternity ward & 2 \\
\hline & & Health center without maternity ward & 3 \\
\hline & & Health post with maternity ward & 4 \\
\hline & & Health post without maternity ward & 5 \\
\hline & & Dispensary & 6 \\
\hline & & Other: & 7 \\
\hline \multirow[t]{4}{*}{1.5} & \multirow[t]{4}{*}{ Type of sector } & Government & 1 \\
\hline & & NGO & 2 \\
\hline & & Private & 3 \\
\hline & & Other: & 4 \\
\hline \multirow[t]{4}{*}{1.6} & \multirow{4}{*}{ Result of the interview } & Complete & 1 \\
\hline & & Incomplete & 2 \\
\hline & & Refused & 3 \\
\hline & & Other: & 4 \\
\hline
\end{tabular}

\section{Reproductive history}

\begin{tabular}{|c|c|c|c|c|}
\hline No. & QUESTIONS & CODING CATEGORIES & & GO TO \\
\hline 2.1 & $\begin{array}{l}\text { How many living children of your own do } \\
\text { you have? }\end{array}$ & Living children: & & \\
\hline \multirow[t]{3}{*}{2.2} & \multirow[t]{3}{*}{ How long ago did your last pregnancy end? } & Number of days: & & \\
\hline & & Number of weeks: & & \\
\hline & & Number of months: & & \\
\hline \multirow[t]{4}{*}{2.3} & \multirow{4}{*}{$\begin{array}{l}\text { In the future, would you like to have more } \\
\text { children? }\end{array}$} & Yes & 1 & \\
\hline & & No & 2 & $\begin{array}{l}\text { next } \\
\text { section }\end{array}$ \\
\hline & & Other: & 3 & \\
\hline & & Don't know & 98 & \\
\hline \multirow[t]{3}{*}{2.4} & \multirow{3}{*}{$\begin{array}{l}\text { How long would you like to wait before } \\
\text { becoming pregnant again? }\end{array}$} & Number of months: & & \\
\hline & & Number of years: & & \\
\hline & & Other: & & \\
\hline
\end{tabular}

3. FP and optimal birth spacing

\begin{tabular}{|c|c|c|c|c|}
\hline No. & QUESTIONS & CODING CATEGORIES & & GO TO \\
\hline $\begin{array}{l}\text { Inter } \\
\text { plans }\end{array}$ & $\begin{array}{l}\text { ver: Explain that you will now discuss the FP s } \\
\text { use a FP method. }\end{array}$ & ervices she received during this visi & & \\
\hline 3.1 & During this PNC visit, did any health & Yes & 1 & \\
\hline & $\begin{array}{l}\text { provider tell you how soon after delivery a } \\
\text { woman can get pregnant? }\end{array}$ & No & 2 & 3.3 \\
\hline 3.2 & $\begin{array}{l}\text { According to what they told you, how soon } \\
\text { after delivery can a woman get pregnant }\end{array}$ & $\begin{array}{l}\text { Whenever she restarts her sexual } \\
\text { relations }\end{array}$ & 1 & \\
\hline & again? & After her period returns & 2 & \\
\hline & Interviower. Anet all that ande & $\begin{array}{l}\text { After she stops breastfeeding } \\
\text { exclusively }\end{array}$ & 3 & \\
\hline & Interviewer: Mark all that apply. & $\begin{array}{l}\text { After she stops breastfeeding } \\
\text { altogether }\end{array}$ & 4 & \\
\hline & & After 6 months & 5 & \\
\hline & & Other: & 6 & \\
\hline & & Don't know & 98 & \\
\hline
\end{tabular}




\begin{tabular}{|c|c|c|c|c|c|}
\hline \multirow[t]{2}{*}{3.3} & \multirow[b]{2}{*}{$\begin{array}{l}\text { During this PNC visit, did any } \\
\text { health provider talk to you about } \\
\text { the importance of waiting for } \\
\text { some time before getting pregnant } \\
\text { again? }\end{array}$} & \multicolumn{2}{|l|}{ Yes } & 1 & \\
\hline & & \multicolumn{2}{|l|}{ No } & 2 & 3.5 \\
\hline \multirow[t]{4}{*}{3.4} & \multirow{4}{*}{$\begin{array}{l}\text { After delivery, what is the ideal } \\
\text { amount of time that a woman } \\
\text { should wait before getting } \\
\text { pregnant again? }\end{array}$} & \multirow{2}{*}{\multicolumn{2}{|c|}{$\begin{array}{l}\text { Months: } \\
\text { Years: }\end{array}$}} & & \\
\hline & & & & & \\
\hline & & \multicolumn{2}{|l|}{ Other: } & & \\
\hline & & \multicolumn{2}{|l|}{ Don't know } & 98 & \\
\hline \multirow[t]{2}{*}{3.5} & \multirow{2}{*}{$\begin{array}{l}\text { During your time in this facility, did } \\
\text { you receive any information about } \\
\text { FP methods? }\end{array}$} & \multicolumn{2}{|l|}{ Yes } & 1 & \\
\hline & & \multicolumn{2}{|l|}{ No } & 2 & - 3.8 \\
\hline \multirow[t]{5}{*}{3.6} & \multirow{5}{*}{ How did you get this information? } & \multicolumn{2}{|l|}{ Video } & 1 & \\
\hline & & \multirow{2}{*}{\multicolumn{2}{|c|}{ Individual talk }} & 2 & \\
\hline & & & & 3 & \\
\hline & & \multicolumn{2}{|c|}{$\begin{array}{l}\text { Group talk } \\
\text { Written material }\end{array}$} & 4 & \\
\hline & & \multicolumn{2}{|l|}{ Other: } & 5 & \\
\hline \multirow[t]{24}{*}{3.7} & \multirow{3}{*}{$\begin{array}{l}\text { Which methods were discussed in } \\
\text { the information you received? }\end{array}$} & \multicolumn{2}{|c|}{ Combined oral contraceptives } & 1 & \\
\hline & & Minipills (pr & only pills) & 2 & \\
\hline & & Emergency & ptive pills & 3 & \\
\hline & Interviewer: Mark all that apply. & $\begin{array}{l}\text { Progestin-ol } \\
2 \text { or } 3 \text { mont }\end{array}$ & ables (injection every & 4 & \\
\hline & & \begin{tabular}{|l|l|l}
2 or 3 mont \\
Monthly inje
\end{tabular} & & 5 & \\
\hline & & Combined & & 6 & \\
\hline & & Combined & ings & 7 & \\
\hline & & Jadelle imp & & 8 & \\
\hline & & Implanon im & & 9 & \\
\hline & & Sinoplant (I) & & 10 & \\
\hline & & IUD & & 11 & \\
\hline & & IUS & & 12 & \\
\hline & & Female con & & 13 & \\
\hline & & Male condo & & 14 & \\
\hline & & Diaphragm & & 15 & \\
\hline & & Spermicide & & 16 & \\
\hline & & Cervical ca & & 17 & \\
\hline & & Female ster & & 18 & \\
\hline & & Vasectomy & & 19 & \\
\hline & & Fertility aw & nethods & 20 & \\
\hline & & Withdrawa & & 21 & \\
\hline & & LAM & & 22 & \\
\hline & & Other: & & 23 & \\
\hline & & Don't know & & 98 & \\
\hline 3.8 & During this visit, did a health & Yes & & 1 & \\
\hline & $\begin{array}{l}\text { provider talk to you about LAM or } \\
\text { the method of feeding your baby } \\
\text { only with breast milk? }\end{array}$ & No & & 2 & 3.10 \\
\hline 3.9 & $\begin{array}{l}\text { What are the three conditions that } n \\
\text { the baby only with breast milk? }\end{array}$ & nust be fulfil & der to use LAM or the & metho & f feeding \\
\hline & $\begin{array}{l}\text { Interviewer: Record spontaneous } \\
\text { responses, then ask about remaining } \\
\text { items. }\end{array}$ & Not aided & Aided & Don't & \\
\hline & $\begin{array}{l}\text { Feed the baby exclusively or } \\
\text { almost exclusively with breast milk. }\end{array}$ & 1 & 2 & & 98 \\
\hline & $\begin{array}{l}\text { Baby must be less than } 6 \text { months } \\
\text { old. }\end{array}$ & 1 & 2 & & 98 \\
\hline & $\begin{array}{l}\text { Monthly bleedings have not } \\
\text { resumed since delivery. }\end{array}$ & 1 & 2 & & 98 \\
\hline 3.10 & During this visit, did a health & Yes & & 1 & \\
\hline & $\begin{array}{l}\text { provider offer you a contraceptive } \\
\text { method? }\end{array}$ & No & & 2 & \\
\hline 3.11 & Did you receive a contraceptive & Yes & & 1 & \\
\hline & method today? & No & & 2 & 3.15 \\
\hline
\end{tabular}




\begin{tabular}{|c|c|c|c|c|}
\hline 3.12 & $\begin{array}{l}\text { Which contraceptive } \\
\text { method did you receive? } \\
\text { Interviewer: Mark all that } \\
\text { apply. Ask: "Something } \\
\text { else?" }\end{array}$ & \begin{tabular}{|l|} 
Combined oral contraceptives \\
Minipills (progestin-only pills) \\
Emergency contraceptive pills \\
$\begin{array}{l}\text { Progestin-only injectables (injection every } 2 \text { or } 3 \\
\text { months) }\end{array}$ \\
Monthly injectables \\
Combined patches \\
Combined vaginal rings \\
Jadelle implants \\
Implanon implants \\
Sinoplant (II) implants \\
IUD \\
IUS \\
Male condoms \\
Female condoms \\
Diaphragms \\
Spermicides \\
Cervical caps \\
Female sterilization \\
Vasectomy \\
Fertility awareness methods \\
Withdrawal \\
LAM \\
Other: \\
\end{tabular} & $\begin{array}{c}5 \\
6 \\
7 \\
8 \\
9 \\
10 \\
11 \\
12 \\
13 \\
14 \\
15 \\
16 \\
17 \\
18 \\
19 \\
20 \\
21 \\
22 \\
23\end{array}$ & \\
\hline 3.13 & $\begin{array}{l}\text { Is this the method you } \\
\text { wanted to use? }\end{array}$ & Yes & 1 & $\begin{array}{l}\text { next } \\
\text { section }\end{array}$ \\
\hline & & No & 2 & \\
\hline 3.14 & $\begin{array}{l}\text { Why did you not receive } \\
\text { the method you wanted to } \\
\text { use? } \\
\text { Interviewer: Mark all that } \\
\text { apply. }\end{array}$ & \begin{tabular}{|l|} 
Cost \\
Method was not available. \\
There is no operating room or surgeon. \\
Providers said I have contraindications. \\
Other:
\end{tabular} & $\begin{array}{l}1 \\
2 \\
3 \\
5\end{array}$ & $\begin{array}{l}\text { next } \\
\text { - section } \\
\text { for all } \\
\text { responses }\end{array}$ \\
\hline 3.15 & $\begin{array}{l}\text { Would you have liked } \\
\text { to receive an FP method } \\
\text { before leaving this } \\
\text { facility? }\end{array}$ & \begin{tabular}{|l|} 
Yes \\
No
\end{tabular} & $\begin{array}{l}1 \\
2\end{array}$ & 3.17 \\
\hline 3.16 & $\begin{array}{l}\text { Why did you not receive } \\
\text { a contraceptive method } \\
\text { today? }\end{array}$ & $\begin{array}{l}\text { She is breastfeeding and thinks she does not need } \\
\text { a contraceptive method. } \\
\text { She is not breastfeeding but thinks she does not } \\
\text { need a contraceptive method. }\end{array}$ & 3 & $\begin{array}{l}3.19 \\
3.19\end{array}$ \\
\hline & & \begin{tabular}{|l|} 
Cost \\
She was not offered one. \\
The method she wanted was not available. \\
There is no operating room or surgeon. \\
Providers said she has contraindications. \\
Other: \\
\end{tabular} & \begin{tabular}{c|}
5 \\
6 \\
7 \\
8 \\
9 \\
10
\end{tabular} & \\
\hline 3.17 & $\begin{array}{l}\text { Are you currently using an } \\
\text { FP method? }\end{array}$ & \begin{tabular}{|l|} 
Yes \\
No \\
\end{tabular} & $\frac{1}{2}$ & 13.19 \\
\hline
\end{tabular}




\begin{tabular}{|c|c|c|c|c|}
\hline \multirow[t]{23}{*}{3.18} & \multirow{23}{*}{$\begin{array}{l}\text { Which contraceptive } \\
\text { method are you using? } \\
\text { Interviewer: Mark all that } \\
\text { apply. }\end{array}$} & Combined oral contraceptives & 1 & $\begin{array}{l}\text { next } \\
\text { section }\end{array}$ \\
\hline & & Minipills (progestin-only pills) & 2 & $\begin{array}{l}\text { next } \\
\text { section }\end{array}$ \\
\hline & & Emergency contraceptive pills & 3 & $\begin{array}{l}\text { next } \\
\text { section }\end{array}$ \\
\hline & & $\begin{array}{l}\text { Progestin-only injectables (injection every } 2 \text { or } 3 \\
\text { months) }\end{array}$ & 4 & $\begin{array}{l}\text { next } \\
\text { section }\end{array}$ \\
\hline & & Monthly injectables & 5 & $\begin{array}{l}\text { next } \\
\text { section }\end{array}$ \\
\hline & & Combined patches & 6 & $\begin{array}{l}\text { next } \\
\text { section }\end{array}$ \\
\hline & & Combined vaginal rings & 7 & $\begin{array}{l}\text { next } \\
\text { section }\end{array}$ \\
\hline & & Jadelle implants & 8 & $\begin{array}{l}\text { next } \\
\text { section }\end{array}$ \\
\hline & & Implanon implants & 9 & $\begin{array}{l}\text { next } \\
\text { section }\end{array}$ \\
\hline & & Sinoplant (II) implants & 10 & $\begin{array}{l}\text { next } \\
\text { section }\end{array}$ \\
\hline & & IUD & 11 & $\begin{array}{l}\text { next } \\
\text { section }\end{array}$ \\
\hline & & IUS & 12 & $\begin{array}{l}\text { next } \\
\text { section }\end{array}$ \\
\hline & & Male condoms & 13 & $\begin{array}{l}\text { next } \\
\text { section }\end{array}$ \\
\hline & & Female condoms & 14 & $\begin{array}{l}\text { next } \\
\text { section }\end{array}$ \\
\hline & & Diaphragms & 15 & $\begin{array}{l}\text { next } \\
\text { section }\end{array}$ \\
\hline & & Spermicides & 16 & $\begin{array}{l}\text { next } \\
\text { section }\end{array}$ \\
\hline & & Cervical caps & 17 & $\begin{array}{l}\text { next } \\
\text { section }\end{array}$ \\
\hline & & Female sterilization & 18 & $\begin{array}{l}\text { next } \\
\text { section }\end{array}$ \\
\hline & & Vasectomy & 19 & $\begin{array}{l}\text { next } \\
\text { section }\end{array}$ \\
\hline & & Fertility awareness methods & 20 & $\begin{array}{l}\text { next } \\
\text { section }\end{array}$ \\
\hline & & Withdrawal & 21 & $\begin{array}{l}\text { next } \\
\text { section }\end{array}$ \\
\hline & & LAM & 22 & \\
\hline & & Other: & 23 & $\begin{array}{l}\text { next } \\
\text { section }\end{array}$ \\
\hline \multirow[t]{2}{*}{3.19} & \multirow{2}{*}{$\begin{array}{l}\text { During this visit, did a } \\
\text { health provider tell you } \\
\text { where you can obtain an } \\
\text { FP method? }\end{array}$} & Yes & 1 & \\
\hline & & No & & 3.21 \\
\hline 3.20 & $\begin{array}{l}\text { Where did they tell } \\
\text { you could obtain an FP } \\
\text { method? }\end{array}$ & & & \\
\hline \multirow[t]{2}{*}{3.21} & \multirow{2}{*}{$\begin{array}{l}\text { Since your baby was } \\
\text { born, have you resumed } \\
\text { menstruating (monthly } \\
\text { periods)? }\end{array}$} & Yes & 1 & \\
\hline & & No & 2 & \\
\hline \multirow[t]{2}{*}{3.22} & \multirow{2}{*}{$\begin{array}{l}\text { Since your baby was born, } \\
\text { have you resumed sexual } \\
\text { relations (having sex)? }\end{array}$} & Yes & 1 & \\
\hline & & No & 2 & \\
\hline
\end{tabular}


4. Reasons for visit to health facility and integration of maternal and child care

\begin{tabular}{|c|c|c|c|c|}
\hline No. & QUESTIONS & CODING CATEGORIES & & GO TO \\
\hline Inter & ewer: Explain that you will now discuss the reas & ons for the client's visit today. & & \\
\hline 4.1 & What were your reasons for coming to the & PNC & 1 & \\
\hline & clinic today? & Child immunization & 2 & \\
\hline & & FP & 3 & \\
\hline & & Removal of sutures & 4 & \\
\hline & Interviewer: Mark all that apply. & Baby check-up & 5 & \\
\hline & & Feeding advice & 6 & \\
\hline & & Seeking care because mother is sick & 7 & \\
\hline & & Seeking care because newborn is sick & 8 & \\
\hline & & Other: & 9 & \\
\hline 4.2 & During your visit, did any provider offer you & Yes & 1 & \\
\hline & services other than the ones you requested? & No & 2 & $\begin{array}{l}\text { next } \\
\text { section }\end{array}$ \\
\hline 4.3 & What services did they offer you? & PNC check-up & 1 & \\
\hline & & FP & 2 & \\
\hline & & Other: & 3 & \\
\hline
\end{tabular}

\section{Access to PNC}

No. QUESTIONS

CODING CATEGORIES

Interviewer: Explain that you will now ask a few questions about the PNC she received.

$5.1 \quad$ How many times have you visited a health facility since the birth Number of visits: of this baby? (including this visit)?

5.2 In how many of these visits have you been seen by a health provider to make sure that you are recovering well from your pregnancy?

5.3 In how many of these visits has your baby been seen by a health Number: provider?

6. Information about danger signs during the $P N C$ period

\begin{tabular}{|c|c|c|c|c|c|}
\hline \multirow{2}{*}{$\frac{\mathrm{No}}{6.1}$} & \multirow{3}{*}{$\begin{array}{l}\text { QUESTIONS } \\
\text { During this postnatal visit, has a health provider } \\
\text { talked to you about danger signs in the PNC period } \\
\text { that need immediate medical care? }\end{array}$} & \multicolumn{2}{|c|}{ CODING CATEGORIES } & & $\mathrm{GO} \mathrm{TO}$ \\
\hline & & \multicolumn{2}{|c|}{ Yes } & 1 & \multirow[b]{2}{*}{6.3} \\
\hline & & \multicolumn{2}{|l|}{ No } & 2 & \\
\hline \multirow[t]{20}{*}{6.2} & $\begin{array}{l}\text { What are the danger signs in the PNC period for } \\
\text { which they told you that you need immediate medical } \\
\text { care? }\end{array}$ & \multirow[b]{2}{*}{ Not aided } & \multirow[b]{2}{*}{ Aided } & \multirow{2}{*}{\multicolumn{2}{|c|}{ Don't know }} \\
\hline & $\begin{array}{l}\text { Interviewer: Record spontaneous responses, then ask } \\
\text { about remaining items. }\end{array}$ & & & & \\
\hline & Bleeding & 1 & 2 & \multicolumn{2}{|c|}{98} \\
\hline & Convulsions or fits & 1 & 2 & \multicolumn{2}{|c|}{98} \\
\hline & Fast or difficult breathing & 1 & 2 & \multicolumn{2}{|c|}{98} \\
\hline & Fever & 1 & 2 & \multicolumn{2}{|c|}{98} \\
\hline & Abdominal pain & 1 & 2 & \multicolumn{2}{|c|}{98} \\
\hline & Feeling ill & 1 & 2 & \multicolumn{2}{|c|}{98} \\
\hline & Swollen, red, or tender breasts or sore nipples & 1 & 2 & \multicolumn{2}{|c|}{98} \\
\hline & Urine dribbling or pain/burning while urinating & 1 & 2 & \multicolumn{2}{|c|}{98} \\
\hline & Pain in the perineum or draining pus & 1 & 2 & \multicolumn{2}{|c|}{98} \\
\hline & Foul-smelling vaginal discharge (lochia) & 1 & 2 & \multicolumn{2}{|c|}{98} \\
\hline & Broken episiotomy scar & 1 & 2 & \multicolumn{2}{|c|}{98} \\
\hline & Bleeding from C-section scar & 1 & 2 & \multicolumn{2}{|c|}{98} \\
\hline & Pus oozing from C-section scar/site & 1 & 2 & \multicolumn{2}{|c|}{98} \\
\hline & Excessive tiredness or breathlessness & 1 & 2 & \multicolumn{2}{|c|}{98} \\
\hline & Swollen hands, face, legs & 1 & 2 & \multicolumn{2}{|c|}{98} \\
\hline & Severe headache or blurred vision & 1 & 2 & \multicolumn{2}{|c|}{98} \\
\hline & Pain in the calf muscle (Thrombophlebitis) & 1 & 2 & \multicolumn{2}{|c|}{98} \\
\hline & Other: & 1 & 2 & \multicolumn{2}{|c|}{98} \\
\hline \multirow[t]{2}{*}{6.3} & During your visit today, did a health provider talk to & \multicolumn{2}{|l|}{ Yes } & 1 & \\
\hline & $\begin{array}{l}\text { you about the special care women must have after } \\
\text { delivery? }\end{array}$ & No & & \multicolumn{2}{|r|}{5} \\
\hline
\end{tabular}




\begin{tabular}{|c|c|c|c|c|}
\hline \multirow[t]{9}{*}{6.4} & $\begin{array}{l}\text { What recommendations did you receive from the } \\
\text { health personnel about the special care women must } \\
\text { have after delivery? } \\
\text { Interviewer: Record spontaneous responses, then ask } \\
\text { about remaining items. }\end{array}$ & Not aided & Aided & \\
\hline & Get enough rest and sleep. & 1 & 2 & \begin{tabular}{|c|} 
Don't know \\
98 \\
\end{tabular} \\
\hline & Eat well, and eat everything. & 1 & 2 & 98 \\
\hline & Wash perineum daily and after fecal excretion. & 1 & 2 & 98 \\
\hline & $\begin{array}{l}\text { Change perineal pads every } 4 \text { to } 6 \text { hours, or more } \\
\text { frequently, if necessary. }\end{array}$ & 1 & 2 & 98 \\
\hline & Wash used pads or dispose of them safely. & 1 & 2 & 98 \\
\hline & Wash her body daily. & 1 & 2 & 98 \\
\hline & Avoid sexual intercourse until perineal wound heals. & 1 & 2 & 98 \\
\hline & Other: & 1 & 2 & 98 \\
\hline \multirow[t]{2}{*}{6.5} & \multirow[t]{2}{*}{ Did you receive Vitamin A during your visit today? } & \multicolumn{2}{|l|}{ Yes } & \multirow{2}{*}{$\frac{1}{2}$} \\
\hline & & \multicolumn{2}{|l|}{ No } & \\
\hline
\end{tabular}

\section{Breastfeeding}

No. QUESTIONS

CODING CATEGORIES

GO TO

Interviewer: Explain that you will now ask some questions about her newborn's feeding

\begin{tabular}{|c|c|c|c|c|c|}
\hline \multirow[t]{2}{*}{7.1} & \multirow{2}{*}{$\begin{array}{l}\text { During this PNC visit, did a health provider discuss } \\
\text { with you how to feed your baby? }\end{array}$} & \multicolumn{2}{|l|}{ Yes } & 1 & \multirow[b]{2}{*}{7.3} \\
\hline & & No & & 2 & \\
\hline \multirow[t]{8}{*}{7.2} & \multicolumn{5}{|c|}{$\begin{array}{l}\text { Interviewer: Ask this question only if the answer to } 7.1 \text { was Yes. Record spontaneous responses, then } \\
\text { ask about remaining items. }\end{array}$} \\
\hline & $\begin{array}{l}\text { What recommendations did you receive about how } \\
\text { and when breastfeed your baby? }\end{array}$ & Not aided & Aided & \multicolumn{2}{|c|}{ Don't know } \\
\hline & $\begin{array}{l}\text { 1) Exclusive breastfeeding in the first } 6 \text { months after } \\
\text { delivery }\end{array}$ & 1 & 2 & \multicolumn{2}{|r|}{98} \\
\hline & 2) Feed on demand (as often as baby wants) & 1 & 2 & \multicolumn{2}{|r|}{98} \\
\hline & 3) How to breastfeed the baby (position) & 1 & 2 & \multicolumn{2}{|r|}{98} \\
\hline & $\begin{array}{l}\text { 4) How to solve problems related to breastfeeding } \\
\text { the baby }\end{array}$ & 1 & 2 & \multicolumn{2}{|r|}{98} \\
\hline & $\begin{array}{l}\text { 5) How to assess whether the baby is getting enough } \\
\text { food during breastfeeding }\end{array}$ & 1 & 2 & \multicolumn{2}{|r|}{98} \\
\hline & 6) Other: & 1 & 2 & \multicolumn{2}{|r|}{98} \\
\hline \multirow[t]{2}{*}{7.3} & \multirow[t]{2}{*}{ Are you currently breastfeeding your baby? } & \multicolumn{2}{|l|}{ Yes } & 1 & \multirow[b]{2}{*}{$\begin{array}{l}\text { next } \\
\text { section }\end{array}$} \\
\hline & & No & & 2 & \\
\hline \multirow[t]{3}{*}{7.4} & \multirow{3}{*}{$\begin{array}{l}\text { For how long do you plan to continue feeding your } \\
\text { baby with breast milk? }\end{array}$} & \multicolumn{2}{|l|}{ Weeks: } & & \\
\hline & & \multicolumn{2}{|l|}{\begin{tabular}{|l|} 
Months: \\
\end{tabular}} & & \\
\hline & & Don't know & & 98 & \\
\hline \multirow[t]{2}{*}{7.5} & \multirow{2}{*}{$\begin{array}{l}\text { Are you giving this baby any food or liquids other } \\
\text { than breast milk? }\end{array}$} & \multicolumn{2}{|l|}{ Yes (specify) } & 1 & \\
\hline & & \multicolumn{2}{|l|}{ No } & 2 & \\
\hline
\end{tabular}

8. Danger signs for the newborn

\begin{tabular}{|l|l}
\hline No. & QUESTIONS \\
\hline
\end{tabular}

Interviewer: Explain that you will now ask some questions about the information the client received regarding her newborn's health.

8.1 During this PNC visit, did a health provider talk to you about danger signs for which you should bring your baby to a health facility?

\begin{tabular}{|l|l|l|}
\hline Yes & 1 & \\
\hline No & 2 & $\begin{array}{r}\text { bext } \\
\text { section }\end{array}$ \\
\hline
\end{tabular}




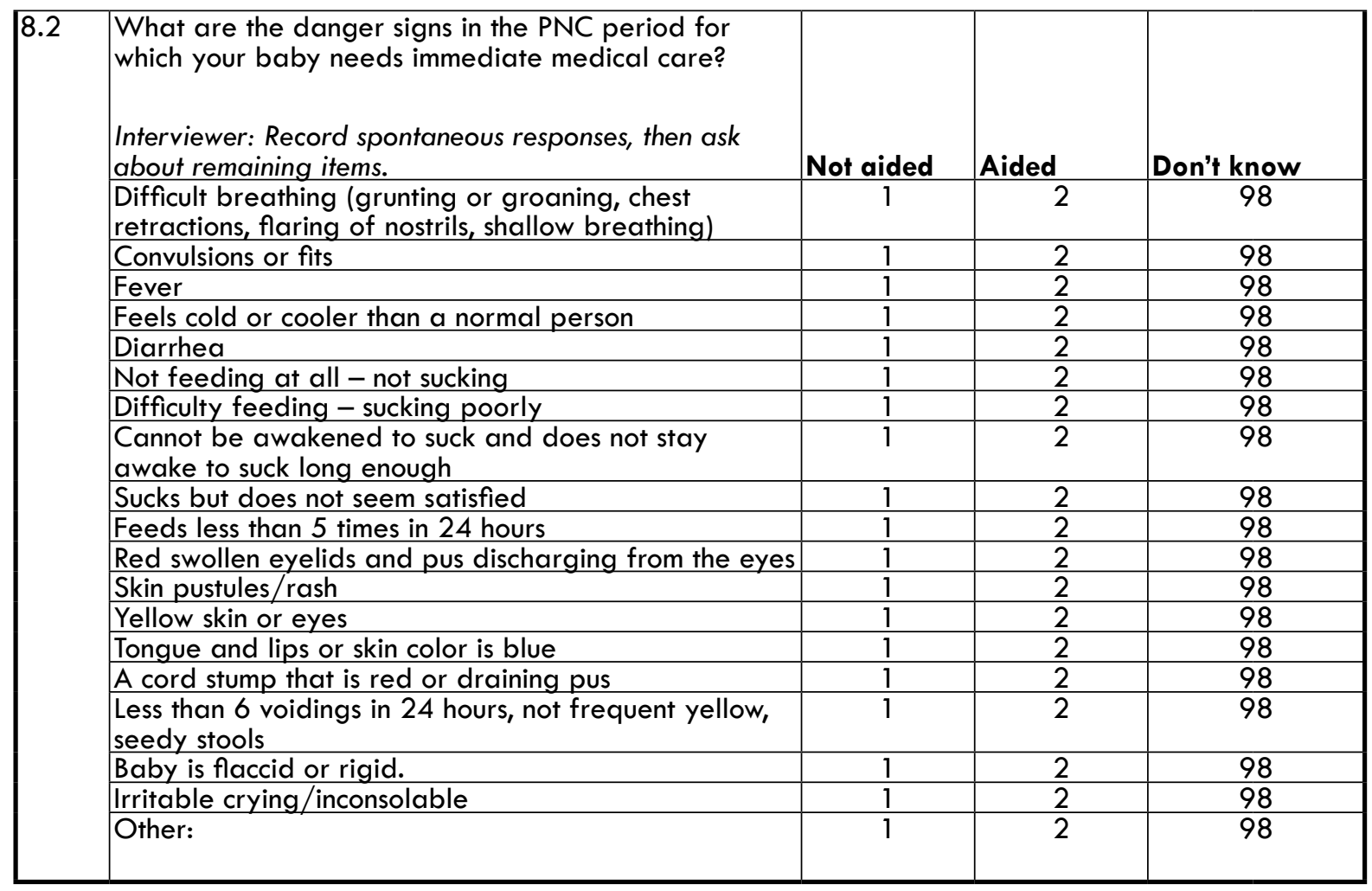

\section{PMTCT of HIV}

\begin{tabular}{|c|c|c|c|c|}
\hline \multirow{4}{*}{\begin{tabular}{|l|} 
No. \\
9.1
\end{tabular}} & QUESTIONS & \multicolumn{2}{|l|}{ CODING CATEGORIES } & \multirow[t]{2}{*}{ GO TO } \\
\hline & \multirow{3}{*}{ Have you ever taken an HIV test? } & Yes & 1 & \\
\hline & & No & 2 & $\begin{array}{l}\text { next } \\
\text { section }\end{array}$ \\
\hline & & Don't know & 3 & $\begin{array}{l}\text { next } \\
\text { section }\end{array}$ \\
\hline \multirow[t]{4}{*}{9.2} & \multirow{4}{*}{$\begin{array}{l}\text { Would you tell me your HIV test results? Please know } \\
\text { that I will keep this information confidential. }\end{array}$} & HIV positive & 1 & \\
\hline & & HIV negative & 2 & $\begin{array}{l}\text { next } \\
\text { section }\end{array}$ \\
\hline & & Would not indicate status & 3 & $\begin{array}{l}\text { next } \\
\text { section }\end{array}$ \\
\hline & & Don't know & 98 & $\begin{array}{l}\text { next } \\
\text { section }\end{array}$ \\
\hline \multirow[t]{2}{*}{9.3} & \multirow{2}{*}{$\begin{array}{l}\text { During your visit today, did a health provider discuss } \\
\text { with you the need for your baby to receive a medicine } \\
\text { to prevent HIV infection? }\end{array}$} & Yes & 1 & \\
\hline & & No & 2 & \\
\hline \multirow[t]{2}{*}{9.4} & \multirow{2}{*}{$\begin{array}{l}\text { Has your baby taken a medicine to prevent HIV } \\
\text { infection? }\end{array}$} & Yes & 1 & \\
\hline & & No & 2 & \\
\hline \multirow[t]{2}{*}{9.5} & \multirow{2}{*}{$\begin{array}{l}\text { During your visit today, did a health provider discuss } \\
\text { with you the need for your baby to receive a medicine } \\
\text { (cotrimoxazole) to prevent opportunistic infections } \\
\text { (getting other infections related to HIV)? }\end{array}$} & Yes & 1 & \\
\hline & & No & 2 & \\
\hline \multirow[t]{2}{*}{9.6} & \multirow{2}{*}{$\begin{array}{l}\text { Has your baby taken a medicine to prevent } \\
\text { opportunistic infections? }\end{array}$} & Yes & 1 & \\
\hline & & No & 2 & \\
\hline \multirow[t]{4}{*}{9.7} & \multirow{4}{*}{$\begin{array}{l}\text { During your visit today, did a health provider give you } \\
\text { any recommendations about how and what to feed } \\
\text { your baby to prevent HIV infection? What did they tell } \\
\text { you? }\end{array}$} & No recommendation & 1 & \\
\hline & & Not to breastfeed at all & 2 & \\
\hline & & Breastfeed exclusively & 3 & \\
\hline & & Other: & 4 & \\
\hline \multirow[t]{2}{*}{9.8} & \multirow{2}{*}{$\begin{array}{l}\text { During your visit today, did you receive information } \\
\text { about where you can go to receive more support about } \\
\text { questions and concerns you may have about HIV? }\end{array}$} & Yes & 1 & \\
\hline & & No & 2 & \\
\hline
\end{tabular}


10. Follow-up and referrals

\begin{tabular}{|c|c|c|c|c|}
\hline No. & QUESTIONS & CODING CATEGORIES & & GO TO \\
\hline 10.1 & During your visit today, were you given any & Yes & 1 & \\
\hline & $\begin{array}{l}\text { information on follow-up care available for you } \\
\text { and your baby? }\end{array}$ & No & 2 & $\begin{array}{l}\text { next } \\
\text { section }\end{array}$ \\
\hline 10.2 & When will you go for a follow-up visit? & Days from now: & & \\
\hline & & Weeks from now: & & \\
\hline & & Other: & & \\
\hline 10.3 & During your visit today, were you given an & Yes & 1 & \\
\hline & appointment for a follow-up visit (return date)? & No & 2 & $\begin{array}{l}\text { next } \\
\text { section }\end{array}$ \\
\hline 10.4 & During your visit today, were you referred for any & Yes & 1 & \\
\hline & services? & No & 2 & $\begin{array}{l}\text { next } \\
\text { section }\end{array}$ \\
\hline 10.5 & For what services were you referred? & PNC check for mother & 1 & \\
\hline & & Child growth monitoring & 2 & \\
\hline & & Immunizations & 3 & \\
\hline & Interviewer: Mark all that apply. & Follow up infant feeding & 4 & \\
\hline & & ARV unit for mother & 5 & \\
\hline & & ARV unit for infant & 6 & \\
\hline & & CD4 count for mother & 7 & \\
\hline & & CD4 count for infant & 8 & \\
\hline & & Cotrimoxazole for infant & 9 & \\
\hline & & Cotrimoxazole for mother & 10 & \\
\hline & & Clinical care for mother & 11 & \\
\hline & & Clinical care for infant & 12 & \\
\hline & & FP & 13 & \\
\hline & & STIs detection and treatment & 14 & \\
\hline & & HIV/AIDS C\&T & 15 & \\
\hline & & Cervical cancer screening & 16 & \\
\hline & & Counseling on how to deal with & 17 & \\
\hline & & violence from partner & & \\
\hline & & Other: & 18 & \\
\hline
\end{tabular}

\section{IEC materials}

\begin{tabular}{|l|l}
\hline No. & QUESTIONS \\
\hline
\end{tabular}

\begin{tabular}{|c|c|c|c|}
\hline \multirow[t]{2}{*}{11.1} & \multirow{2}{*}{$\begin{array}{l}\text { Did you receive any information materials during } \\
\text { this postnatal visit? }\end{array}$} & Yes & 1 \\
\hline & & No & 2 \\
\hline \multirow[t]{7}{*}{11.2} & \multirow{3}{*}{$\begin{array}{l}\text { What were they about? The content of the } \\
\text { information materials? }\end{array}$} & Health care of baby & 1 \\
\hline & & Health care of mother & 2 \\
\hline & & FP & 3 \\
\hline & \multirow{4}{*}{ Interviewer: Mark all that apply. } & STIs & 4 \\
\hline & & HIV/AIDS & 5 \\
\hline & & PMT'CT & 6 \\
\hline & & Other: & 7 \\
\hline
\end{tabular}

12. Satisfaction with services

\begin{tabular}{|c|c|c|c|}
\hline \multirow{5}{*}{\begin{tabular}{|l|} 
No. \\
12.1
\end{tabular}} & QUESTIONS & \multicolumn{2}{|l|}{ CODING CATEGORIES } \\
\hline & \multirow{4}{*}{$\begin{array}{l}\text { How long did you wait between the time you } \\
\text { arrived at this facility and the time you were able } \\
\text { to see a provider for the consultation? }\end{array}$} & Minutes: & \\
\hline & & Hours: & \\
\hline & & Saw provider immediately & 97 \\
\hline & & Don't know & 98 \\
\hline 12.2 & Do you the think the time you waited was too long, & Too long & 1 \\
\hline & reasonable, or short? & Reasonable & 2 \\
\hline & & Short & 3 \\
\hline & & Don't know & 98 \\
\hline
\end{tabular}




\begin{tabular}{|c|c|c|c|c|}
\hline \multirow[t]{8}{*}{12.3} & $\begin{array}{l}\text { Interviewer: Explain that you will now ask about } \\
\text { some common experiences clients have at health } \\
\text { facilities. As you mention each one, ask the client } \\
\text { to say whether she was satisfied, dissatisfied, or } \\
\text { undecided about any of the services received today. }\end{array}$ & Satisfied & Dissatisfied & Undecided \\
\hline & $\begin{array}{l}\text { Ability to discuss problems or concerns about your } \\
\text { and baby's care with the providers }\end{array}$ & 1 & 2 & 3 \\
\hline & $\begin{array}{l}\text { Amount of explanation the providers gave to you } \\
\text { about a problem or treatment }\end{array}$ & 1 & 2 & 3 \\
\hline & Quality of examination and treatment provided & 1 & 2 & 3 \\
\hline & $\begin{array}{l}\text { Visual privacy during examination (that other } \\
\text { clients could not see you) }\end{array}$ & 1 & 2 & 3 \\
\hline & $\begin{array}{l}\text { Auditory privacy during discussion (that other } \\
\text { clients could not hear you) }\end{array}$ & 1 & 2 & 3 \\
\hline & Cleanliness of this facility & 1 & 2 & 3 \\
\hline & How the clinic staff treated you & 1 & 2 & 3 \\
\hline \multirow[t]{3}{*}{12.4} & \multirow{3}{*}{$\begin{array}{l}\text { Would you strongly, not strongly, or never } \\
\text { recommend a friend to this facility for PNC? }\end{array}$} & \multicolumn{2}{|c|}{ Strongly recommend } & 1 \\
\hline & & \multicolumn{2}{|c|}{ Recommend, but not strongly } & 2 \\
\hline & & \multicolumn{2}{|c|}{\begin{tabular}{|l|} 
Never recommend \\
Don't know
\end{tabular}} & 3 \\
\hline
\end{tabular}

\section{Male involvement}

\begin{tabular}{|c|c|c|c|c|}
\hline \multirow{3}{*}{\begin{tabular}{|l|} 
No. \\
13.1
\end{tabular}} & QUESTIONS & CODING CATEGORIES & \multirow{2}{*}{\multicolumn{2}{|c|}{$\frac{\mathrm{GOTO}}{13.3}$}} \\
\hline & \multirow{2}{*}{$\begin{array}{l}\text { Did the baby's father or your current partner } \\
\text { accompany you to this PNC visit? }\end{array}$} & Yes & & \\
\hline & & No & 2 & \\
\hline \multirow[t]{2}{*}{13.2} & \multirow{2}{*}{$\begin{array}{l}\text { During this visit, did a health provider advise you to } \\
\text { encourage your partner to accompany you to your } \\
\text { PNC visits? }\end{array}$} & Yes & 1 & \\
\hline & & No & 2 & \\
\hline \multirow[t]{3}{*}{13.3} & \multirow{3}{*}{$\begin{array}{l}\text { During your last pregnancy or after you gave birth, } \\
\text { has your partner beaten or insulted you at any time? }\end{array}$} & Yes & 1 & \\
\hline & & No & 2 & 13.5 \\
\hline & & No response & 99 & 13.5 \\
\hline \multirow[t]{2}{*}{13.4} & \multirow{2}{*}{$\begin{array}{l}\text { Have you talked about this issue to a health } \\
\text { provider? }\end{array}$} & Yes & 1 & \\
\hline & & No & 2 & \\
\hline \multirow[t]{3}{*}{13.5} & \multirow{3}{*}{$\begin{array}{l}\text { Would you like your partner to receive information } \\
\text { about FP methods? }\end{array}$} & Yes & 1 & \\
\hline & & No & 2 & \\
\hline & & Don't know & 98 & \\
\hline \multirow[t]{3}{*}{13.6} & \multirow{3}{*}{$\begin{array}{l}\text { Would you like you and your partner to talk with } \\
\text { somebody at this clinic about how both of you can } \\
\text { get protection from HIV infection? }\end{array}$} & Yes & 1 & \\
\hline & & No & 2 & \\
\hline & & Don't know & 98 & \\
\hline
\end{tabular}

14. Costs

\begin{tabular}{|c|c|c|c|}
\hline No. & QUESTIONS & CODING CATEGORIES & \\
\hline \multirow[t]{2}{*}{14.1} & $\begin{array}{l}\text { How much did you pay for all services or treatments } \\
\text { you received at this facility today? How much did } \\
\text { you pay for travel? }\end{array}$ & $\begin{array}{l}\text { Fees for client card: } \\
\text { Fees for consultation: } \\
\text { Fees for laboratory tests: } \\
\text { Fees for medicines: } \\
\text { Other: }\end{array}$ & \\
\hline & & \begin{tabular}{|l} 
I did not pay anything at the clinic. \\
Travel: \\
Total:
\end{tabular} & \\
\hline \multirow[t]{2}{*}{14.2} & What do you think of the costs of your treatment? & \begin{tabular}{|l|} 
They were ok. \\
Too much \\
Other:
\end{tabular} & $\begin{array}{l}1 \\
2 \\
3\end{array}$ \\
\hline & & Don't know & 98 \\
\hline
\end{tabular}


15. Accessibility

\begin{tabular}{|c|c|c|c|c|}
\hline No. & QUESTIONS & CODING CA & & GO TO \\
\hline 15.1 & By what means of transport did you get to the clinic & Taxi & 1 & \\
\hline & today? & Bus & 2 & \\
\hline & & Train & 3 & \\
\hline & & Private car & 4 & \\
\hline & Inferviewer: Mark all that apply. & Bicycle & 5 & \\
\hline & & Walk & 6 & \\
\hline & & Other: & 7 & \\
\hline 15.2 & Approximately how long did it take you to get to the & Hours: & & \\
\hline & clinic today? & Minutes: & & \\
\hline 15.3 & Are the hours of service at this facility appropriate for & Yes & 1 & 15.5 \\
\hline & you? & No & 2 & \\
\hline 15.4 & Why not? & & & \\
\hline 15.5 & $\begin{array}{l}\text { When you arrived to the health facility, did you have } \\
\text { any problem to receive care? }\end{array}$ & Yes (specify) & 1 & \\
\hline & & No & 2 & \\
\hline
\end{tabular}

16. Demographics

No. QUESTIONS

16.1 How old are you?

16.2 What is your current marital status?

CODING CATEGORIES

Age in years:

Married, monogamous

Married, polygamous

Cohabiting/living with partner

Single, never married

Divorced/separated/widowed

16.3 What is the highest level of school you attended?

Did not attend formal school

Primary

Secondary

Tertiary

Other: 


\section{Provider interview}

\section{INSTRUCTIONS FOR THE}

INTERVIEWERS: Interview all health facility staff who are responsible for providing PNC FP services to PNC clients, and those who participate in activities with postnatal women for PMTCT of HIV/STIs (if applicable in the study objectives). Please interview staff at the end of the working day or during their breaks. Make it clear that you are seeking their assistance in finding ways of improving the functioning and quality of the services offered by facilities in general and are not evaluating the performance of the facility or of them individually. For each item, circle the code of the adequate response or describe, as appropriate. Read the following greeting when you meet with each provider that you will interview.
GREETING: Good morning. My name is , and I work for

We are currently doing a study about the way that family planning services are being integrated to postnatal care in the country and the problems that present obstacles to integration. As a part of this study, we are interviewing all health providers who participate in postnatal care, family planning services for postnatal women, and activities to prevent mother-to-child transmission of HIV. These interviews are not to evaluate individual facilities or providers. We are visiting a number of facilities. All the information you give me will be confidential, and no one will know what you said. I will not record your name in the questionnaire, and there will be no way in which the responses you give me can be directly linked to you. They will all be confidential.

1. Facility identification

\begin{tabular}{|c|c|c|c|}
\hline No. & QUESTIONS & \multicolumn{2}{|l|}{ CODING CATEGORIES } \\
\hline 1.1 & Date of interview & \multicolumn{2}{|l|}{ (Day/Month/ Year) } \\
\hline 1.2 & Facility name & & \\
\hline 1.3 & City or locality & & \\
\hline 1.4 & Type of facility & Hospital & 1 \\
\hline & & Health center with maternity ward & 2 \\
\hline & & Health center without maternity ward & 3 \\
\hline & & Health post with maternity ward & 4 \\
\hline & & Health post without maternity ward & 5 \\
\hline & & Dispensary & 6 \\
\hline & & Other: & 7 \\
\hline 1.5 & Type of sector & Government & 1 \\
\hline & & NGO & 2 \\
\hline & & Private & 3 \\
\hline & & Other: & 4 \\
\hline 1.6 & Result of the interview & Complete & 1 \\
\hline & & Incomplete & 2 \\
\hline & & Refused & 3 \\
\hline & & Other: & 4 \\
\hline
\end{tabular}


2. Demographics and professional experience

\begin{tabular}{|c|c|c|c|}
\hline \multirow{3}{*}{\begin{tabular}{|l|} 
No. \\
2.1
\end{tabular}} & \multirow{3}{*}{$\begin{array}{l}\text { QUESTIONS } \\
\text { Sex } \\
\text { Interviewer: Please mark. }\end{array}$} & \multicolumn{2}{|l|}{ CODING CATEGORIES } \\
\hline & & Male & 1 \\
\hline & & Female & 2 \\
\hline 2.2 & How old are you? & Age in years: & \\
\hline \multirow[t]{9}{*}{2.3} & \multirow[t]{9}{*}{ What is your current technical qualification? } & Specialist doctor & 1 \\
\hline & & General doctor & 2 \\
\hline & & Social Service doctor & 3 \\
\hline & & Intern MD student & 4 \\
\hline & & Professional nurse & 5 \\
\hline & & Auxiliary nurse & 6 \\
\hline & & Nursing student & 7 \\
\hline & & Social worker & 8 \\
\hline & & Other: & 9 \\
\hline 2.4 & $\begin{array}{l}\text { How many years ago did you graduate with this } \\
\text { degree? }\end{array}$ & Years: & \\
\hline \multirow[t]{2}{*}{2.5} & \multirow[t]{2}{*}{ How long have you been working at this facility? } & Months: & \\
\hline & & Years: & \\
\hline \multirow[t]{3}{*}{2.6} & \multirow[t]{3}{*}{ In which unit or department are you currently working? } & PNC & 1 \\
\hline & & $\mathrm{FP}$ & 2 \\
\hline & & Other: & 3 \\
\hline \multirow[t]{15}{*}{2.7} & \multirow[t]{15}{*}{ What services do you directly provide at this facility? } & FP counseling & 1 \\
\hline & & Contraceptives & 2 \\
\hline & & ANC care & 3 \\
\hline & & Delivery & 4 \\
\hline & & PNC & 5 \\
\hline & & Treatment of abortion complications & 6 \\
\hline & & HIV/AIDS counseling & 7 \\
\hline & & HIV/AIDS testing & 8 \\
\hline & & HIV/AIDS treatment and care & 9 \\
\hline & & STI services & 10 \\
\hline & & Child immunization & 11 \\
\hline & & Child growth monitoring & 12 \\
\hline & & Curative services for women & 13 \\
\hline & & Curative services for children & 14 \\
\hline & & Other: & 15 \\
\hline
\end{tabular}

\section{Integration of PNC and FP}

\begin{tabular}{|c|c|c|c|c|c|c|}
\hline \multirow{10}{*}{\begin{tabular}{|l|} 
No. \\
3.1
\end{tabular}} & QUESTIONS & \multicolumn{4}{|c|}{ CODING CATEGORIES } & GO TO \\
\hline & \multirow{2}{*}{$\begin{array}{l}\text { Interviewer: Ask (a) During your in-service } \\
\text { professional training, have you ever received } \\
\text { training in [read } 1 \text { to } 7] \text { ? For every positive } \\
\text { response, ask: (b) Have you received training in } \\
\text { [... I in the past year? }\end{array}$} & \multicolumn{2}{|c|}{$\begin{array}{l}\text { (a) Ever received } \\
\text { training }\end{array}$} & \multicolumn{2}{|c|}{$\begin{array}{l}\text { (b) Received } \\
\text { training last year }\end{array}$} & \\
\hline & & Yes & No & Yes & No & \\
\hline & $\begin{array}{l}\text { 1) Counseling/health education for postnatal } \\
\text { clients }\end{array}$ & 1 & 2 & 1 & 2 & \\
\hline & $\begin{array}{l}\text { 2) Counseling / health education on newborn } \\
\text { care }\end{array}$ & 1 & 2 & 1 & 2 & \\
\hline & 3) FP counseling techniques & 1 & 2 & 1 & 2 & \\
\hline & 4) FP counseling for postnatal clients & 1 & 2 & 1 & 2 & \\
\hline & $\begin{array}{l}\text { 5) Advantages and disadvantages of different } \\
\text { contraceptive methods }\end{array}$ & 1 & 2 & 1 & 2 & \\
\hline & $\begin{array}{l}\text { 6) Action mechanisms of different family } \\
\text { contraceptive methods }\end{array}$ & 1 & 2 & 1 & 2 & \\
\hline & $\begin{array}{l}\text { 7) Contraindications of FP methods for postnatal } \\
\text { women }\end{array}$ & 1 & 2 & 1 & 2 & \\
\hline
\end{tabular}




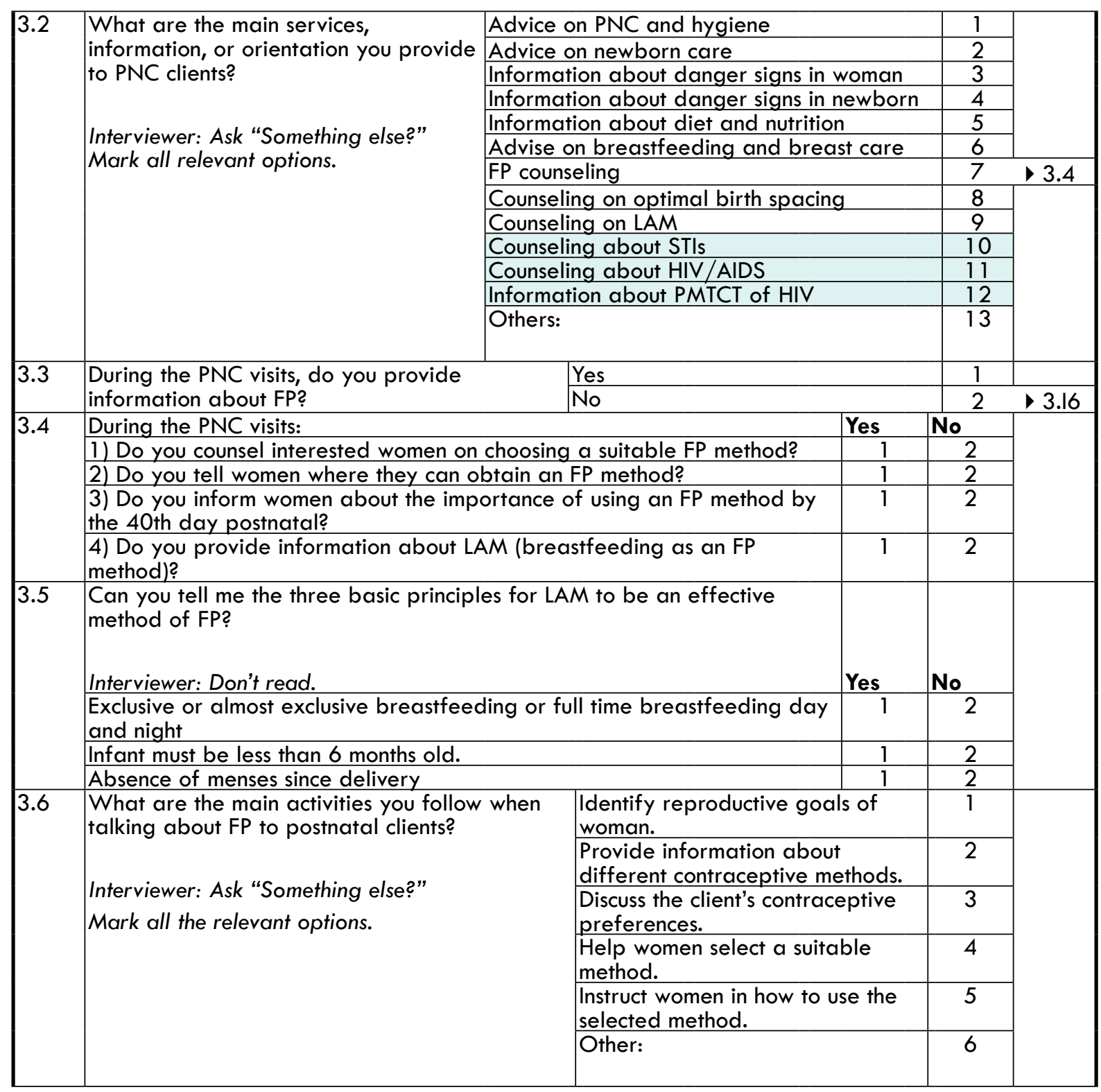




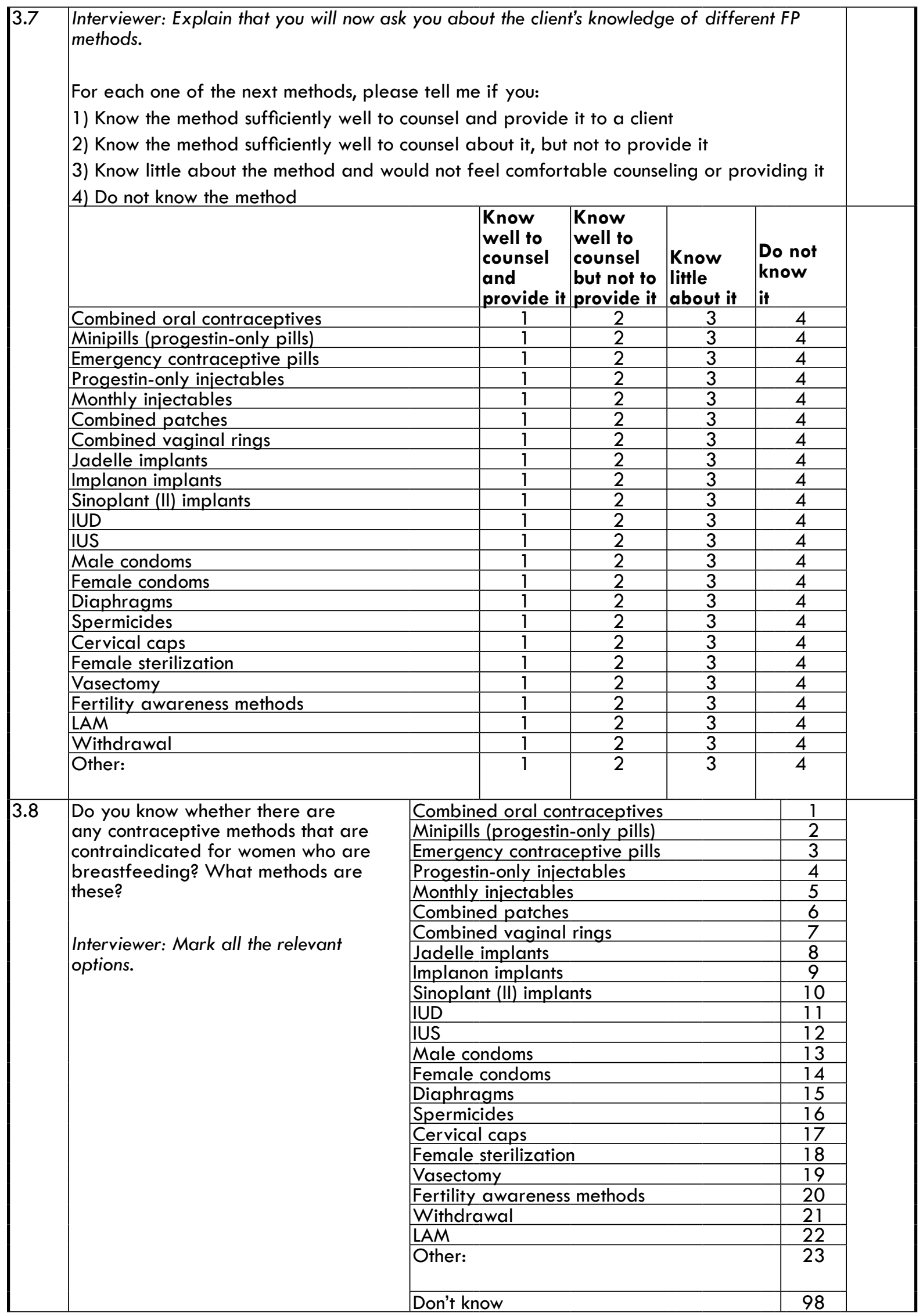




\begin{tabular}{|c|c|c|c|c|c|}
\hline \multirow[t]{24}{*}{3.9} & \multirow{24}{*}{$\begin{array}{l}\text { Do you know whether there are } \\
\text { any contraceptive methods that are } \\
\text { counterindicated for postnatal women } \\
\text { who are not breastfeeding? What } \\
\text { methods are these? }\end{array}$} & \multicolumn{2}{|c|}{ Combined oral contraceptives } & 1 & \\
\hline & & \multicolumn{2}{|c|}{ Mini-pills (progestin-only pills) } & 2 & \\
\hline & & \multicolumn{2}{|c|}{ Emergency contraceptive pills } & 3 & \\
\hline & & \multicolumn{2}{|c|}{ Progestin-only injectables } & 4 & \\
\hline & & \multicolumn{2}{|c|}{ Monthly injectables } & 5 & \\
\hline & & \multicolumn{2}{|c|}{ Combined patches } & 6 & \\
\hline & & \multicolumn{2}{|c|}{ Combined vaginal rings } & 7 & \\
\hline & & \multicolumn{2}{|c|}{ Jadelle implants } & 8 & \\
\hline & & \multicolumn{2}{|c|}{ Implanon implants } & 9 & \\
\hline & & \multicolumn{2}{|c|}{ Sinoplant (II) implants } & 10 & \\
\hline & & \multicolumn{2}{|l|}{ IUD } & 11 & \\
\hline & & \multicolumn{2}{|l|}{ IUS } & 12 & \\
\hline & & \multicolumn{2}{|c|}{ Male condoms } & 13 & \\
\hline & & \multicolumn{2}{|c|}{ Female condoms } & 14 & \\
\hline & & \multicolumn{2}{|c|}{ Diaphragms } & 15 & \\
\hline & & \multicolumn{2}{|c|}{ Spermicides } & 16 & \\
\hline & & \multicolumn{2}{|c|}{ Cervical caps } & 17 & \\
\hline & & \multicolumn{2}{|c|}{ Female sterilization } & 18 & \\
\hline & & Vasector & my & 19 & \\
\hline & & Fertility & awareness methods & 20 & \\
\hline & & Withdra & awal & 21 & \\
\hline & & LAM & & 22 & \\
\hline & & Other: & & 23 & \\
\hline & & Don't kn & low & 98 & 3.11 \\
\hline 3.10 & $\begin{array}{l}\text { For any methods mentioned in } \\
\text { questions } 3.8 \text { and } 3.9, \text { what are the } \\
\text { contraindications? }\end{array}$ & Explain: & & & \\
\hline 3.11 & During the PNC visits, do you encourag & women & Yes & 1 & \\
\hline & $\begin{array}{l}\text { to wait for some time before getting } p \\
\text { again? }\end{array}$ & gnant & No & 2 & \\
\hline 3.12 & According to what you know, what is th & ideal & Less than 2 years & 1 & \\
\hline & time interval between pregnancies to & otect a & $2-3$ years & 2 & \\
\hline & woman's health? & & $3-5$ years & 3 & \\
\hline & & & Other: & 4 & \\
\hline 3.13 & During the PNC visits, do you discuss $w$ & h the & Yes & 1 & \\
\hline & $\begin{array}{l}\text { client how soon after delivery she can } \\
\text { pregnant again? }\end{array}$ & & No & 2 & \\
\hline 3.14 & $\begin{array}{l}\text { According to what you know, how soon } \\
\text { delivery can a woman get pregnant a }\end{array}$ & $\begin{array}{l}\text { after } \\
\text { ain? }\end{array}$ & $\begin{array}{l}4 \text { weeks after delivery, if she } \\
\text { doesn't breastfeed exclusively }\end{array}$ & 1 & \\
\hline & & & As soon as menstruation resumes & 2 & \\
\hline & Interviewer: Mark all the relevant option & & $\begin{array}{l}\text { After } 6 \text { months, if she breastfeeds } \\
\text { exclusively }\end{array}$ & 3 & \\
\hline & & & Other: & 4 & \\
\hline & & & Don't know & 98 & \\
\hline 3.15 & What are the main difficulties you hav & had & Lack of supplies & 1 & \\
\hline & in this facility in providing FP services $f$ & $\mathrm{r}$ PNC & Lack of qualified personnel & 2 & \\
\hline & clients in the last 3 months? & & Lack of equipment & 3 & \\
\hline & & & Failures in equipment & 4 & \\
\hline & & & Inappropriate facilities & 5 & \\
\hline & & & Do not feel sufficiently trained & 6 & \\
\hline & & & Not enough time to counsel clients & 7 & \\
\hline & & & Other: & 8 & \\
\hline 3.16 & Are there any written guidlines in this $f$ & cility for & Yes & 1 & \\
\hline & providing FP services to PNC clients? & & No & 2 & $\begin{array}{l}\text { next } \\
\text { section }\end{array}$ \\
\hline & & & Don't know & 98 & $\begin{array}{l}\text { next } \\
\text { section }\end{array}$ \\
\hline 3.17 & How well do you know the guidlines fo & & Very well & 1 & \\
\hline & providing FP services to PNC clients? & & Fairly well & 2 & \\
\hline & & & Not well & 3 & \\
\hline
\end{tabular}


4. PNC experience, knowledge, and practices

\begin{tabular}{|c|c|c|c|c|}
\hline No. & QUESTIONS & CODING CATEGORIES & & GO TO \\
\hline 4.1 & Do you currently personally provide PNC? & Yes & $\overline{1}$ & \\
\hline & & No & 2 & $\begin{array}{l}\text { next } \\
\text { section }\end{array}$ \\
\hline 4.2 & $\begin{array}{l}\text { For how many years in total have you } \\
\text { provided this service, including your work } \\
\text { at other facilities? }\end{array}$ & $\begin{array}{l}\text { Years: } \\
\text { Interviewer: If less than } 1 \text { year, record } \\
\text { "00." }\end{array}$ & & \\
\hline 4.3 & Does this health facility have written & Yes & 1 & \\
\hline & guidelines on PNC? & No & 2 & 4.6 \\
\hline 4.4 & How well do you know the guidelines for & Very well & 1 & \\
\hline & PNC? & Fairly well & 2 & \\
\hline & & Not well & 3 & \\
\hline 4.5 & What are the recommendations for & Get enough rest and sleep. & 1 & \\
\hline & personal care that should be given to & Eat well, and eat everything. & 2 & \\
\hline & postnatal women? & $\begin{array}{l}\text { Wash perineum daily and after fecal } \\
\text { excretion. }\end{array}$ & 3 & \\
\hline & Interviewer: Ask "Something else?" & $\begin{array}{l}\text { Change perineal pads every } 4 \text { to } 6 \\
\text { hours, or more frequently if necessary. }\end{array}$ & 4 & \\
\hline & Mark all the relevant options. & $\begin{array}{l}\text { Wash used pads or dispose of them } \\
\text { safely. }\end{array}$ & 5 & \\
\hline & & Wash her body daily. & 6 & \\
\hline & & $\begin{array}{l}\text { Avoid sexual intercourse until perineal } \\
\text { wound heals. }\end{array}$ & 7 & \\
\hline & & Other: & 8 & \\
\hline 4.6 & What are the danger signs in the postnatal & Bleeding & 1 & \\
\hline & period? & Convulsions or fits & 2 & \\
\hline & & Fast or difficult breathing & 3 & \\
\hline & 1 . & Fever & 4 & \\
\hline & Interviewer: Ask "Something else?" & Abdominal pain & 5 & \\
\hline & Mark all the relevant options. & Feeling ill & 6 & \\
\hline & & $\begin{array}{l}\text { Swollen, red, or tender breasts or sore } \\
\text { nipples }\end{array}$ & 7 & \\
\hline & & $\begin{array}{l}\text { Urine dribbling or pain/burning } \\
\text { sensation while urinating }\end{array}$ & 8 & \\
\hline & & Pain in the perineum or draining pus & 9 & \\
\hline & & $\begin{array}{l}\text { Foul-smelling vaginal discharge } \\
\text { (lochia) }\end{array}$ & 10 & \\
\hline & & Broken episiotomy scar & 11 & \\
\hline & & Bleeding from C-section scar & 12 & \\
\hline & & Pus oozing from C-section scar/site & 13 & \\
\hline & & Excessive tiredness or breathlessness & 14 & \\
\hline & & Swollen hands, face, legs & 15 & \\
\hline & & Severe headache or blurred vision & 16 & \\
\hline & & $\begin{array}{l}\text { Pain in the calf muscle } \\
\text { (Thrombophlebitis) }\end{array}$ & 17 & \\
\hline & & Other: & 18 & \\
\hline 4.7 & Can you tell me the major causes of anemia & Iron deficiency & 1 & \\
\hline & in the postnatal period? & Hookworms & 2 & \\
\hline & & Advanced HIV/AIDS & 3 & \\
\hline & Intorviawer. Alark all that annly & Malaria & 4 & \\
\hline & Interviewer: Mark all that apply. & Other: & 5 & \\
\hline
\end{tabular}




\begin{tabular}{|c|c|c|c|}
\hline \multirow[t]{13}{*}{4.8} & \multirow{13}{*}{$\begin{array}{l}\text { How would you look for signs and symptoms } \\
\text { of anemia in your clients? } \\
\text { Interviewer: Mark all that apply. }\end{array}$} & Examine client for pallor. & $\frac{1}{2}$ \\
\hline & & $\begin{array}{l}\text { Examine client's palms, nail beds, inner } \\
\text { eyelids, and tongue (conjunctival and } \\
\text { palmar pallor). }\end{array}$ & 2 \\
\hline & & $\begin{array}{l}\text { Check record for bleeding in } \\
\text { pregnancy, delivery, or postnatal. }\end{array}$ & 3 \\
\hline & & $\begin{array}{l}\text { Ask client whether she had heavy } \\
\text { bleeding since delivery. }\end{array}$ & 4 \\
\hline & & Ask client whether she tires easily. & 5 \\
\hline & & $\begin{array}{l}\text { Ask client whether she gets breathless } \\
\text { during her daily routine. }\end{array}$ & 6 \\
\hline & & $\begin{array}{l}\text { Ask client whether she sometimes has } \\
\text { difficulty walking. }\end{array}$ & 7 \\
\hline & & $\begin{array}{l}\text { Ask client whether she sometimes has } \\
\text { buzzing in the ears. }\end{array}$ & 8 \\
\hline & & $\begin{array}{l}\text { Ask client whether she sometimes feels } \\
\text { palpitations (heart beating fast). }\end{array}$ & 9 \\
\hline & & $\begin{array}{l}\text { Ask client whether she sometimes has } \\
\text { dizziness that stops her from walking. }\end{array}$ & 10 \\
\hline & & Ask client whether her legs feel heavy. & 11 \\
\hline & & Check hemoglobin level. & 12 \\
\hline & & Other: & 13 \\
\hline \multirow[t]{7}{*}{4.9} & \multirow{7}{*}{$\begin{array}{l}\text { What do you do to manage anemia in the } \\
\text { postnatal period? }\end{array}$} & Give a double dose of iron. & 1 \\
\hline & & Give ferrous sulphate and folic acid. & 2 \\
\hline & & Treat hookworms. & 3 \\
\hline & & $\begin{array}{l}\text { Counsel client about eating a } \\
\text { balanced diet. }\end{array}$ & 4 \\
\hline & & Advise the client to rest. & 5 \\
\hline & & $\begin{array}{l}\text { Give the client a blood transfusion, if } \\
\text { needed. }\end{array}$ & 6 \\
\hline & & Other: & 7 \\
\hline \multirow[t]{8}{*}{4.10} & \multirow{8}{*}{$\begin{array}{l}\text { What are the main difficulties you have had } \\
\text { in this facility in providing PNC to women in } \\
\text { the last } 3 \text { months? }\end{array}$} & Lack of supplies & 1 \\
\hline & & Lack of qualified personnel & 2 \\
\hline & & Lack of equipment & 3 \\
\hline & & Failures in equipment & 4 \\
\hline & & Inappropriate facilities & 5 \\
\hline & & Do not feel adequately trained & 6 \\
\hline & & Not enough time to treat clients & 7 \\
\hline & & Other: & 8 \\
\hline
\end{tabular}

\section{Supervision}

\begin{tabular}{|c|c|c|c|c|c|c|}
\hline \multirow{3}{*}{\begin{tabular}{|l|} 
No. \\
5.1
\end{tabular}} & \multirow{3}{*}{$\begin{array}{l}\text { QUESTIONS } \\
\text { In the last } 6 \text { months, has a supervisor spoken with you about } \\
\text { your work or observed your work? }\end{array}$} & \multicolumn{4}{|c|}{ CODING CATEGORIES } & GO TO \\
\hline & & \multicolumn{3}{|l|}{ Yes } & 1 & \\
\hline & & \multicolumn{3}{|l|}{ No } & 2 & $\begin{array}{l}\text { next } \\
\text { section }\end{array}$ \\
\hline 5.2 & $\begin{array}{l}\text { How many times in the last } 6 \text { months has your work been } \\
\text { supervised? }\end{array}$ & \multicolumn{3}{|c|}{ Number of times: } & & \\
\hline \multirow[t]{6}{*}{5.3} & \multicolumn{2}{|c|}{$\begin{array}{l}\text { Did your supervisor do the following the last time she/he supervised } \\
\text { you: }\end{array}$} & Yes & \multicolumn{2}{|l|}{ No } & \\
\hline & \multicolumn{2}{|l|}{ 1) Checked your records } & 1 & \multicolumn{2}{|c|}{2} & \\
\hline & \multicolumn{2}{|l|}{ 2) Observed your work } & 1 & \multicolumn{2}{|c|}{2} & \\
\hline & \multicolumn{2}{|l|}{ 3) Provided feedback on your performance } & 1 & \multicolumn{2}{|c|}{2} & \\
\hline & \multicolumn{2}{|l|}{$\begin{array}{l}\text { 4) Provided updates on administrative or technical issues related to } \\
\text { your work }\end{array}$} & 1 & \multicolumn{2}{|c|}{2} & \\
\hline & \multicolumn{2}{|l|}{ 5) Discussed problems you have encountered } & 1 & & & \\
\hline
\end{tabular}




\section{PMTCT of HIV}

\begin{tabular}{|c|c|c|c|c|c|c|c|}
\hline \multirow{8}{*}{ No. } & QUESTIONS & \multicolumn{5}{|c|}{ CODING CATEGORIES } & GO TO \\
\hline & \multirow{2}{*}{\multicolumn{2}{|c|}{$\begin{array}{l}\text { Interviewer: (a) During your professional } \\
\text { experience, have you ever received training in } \\
\text { [read } 1 \text { to } 5] \text { ? For every positive response, ask: } \\
\text { (b) Have you received training in [...] in the past } \\
\text { year? }\end{array}$}} & \multicolumn{2}{|c|}{$\begin{array}{l}\text { (a) Ever received } \\
\text { training }\end{array}$} & \multicolumn{2}{|c|}{$\begin{array}{l}\text { (b) Received } \\
\text { training last year }\end{array}$} & \\
\hline & & & Yes & No & Yes & No & \\
\hline & & 1 & 2 & 1 & 2 & \\
\hline & \multirow{2}{*}{\multicolumn{2}{|c|}{$\begin{array}{l}\text { 2) Counseling for prevention of HIV } \\
\text { 3) Counseling/social support for HIV/AIDS } \\
\text { infected clients }\end{array}$}} & 1 & 2 & 1 & 2 & \\
\hline & & & 1 & 2 & 1 & 2 & \\
\hline & \multicolumn{2}{|c|}{$\begin{array}{l}\text { 4) Medical management of HIV/AIDS-infected } \\
\text { clients }\end{array}$} & 1 & 2 & 1 & 2 & \\
\hline & \multicolumn{2}{|c|}{ 5) ARV for HIV/AIDS-infected clients } & 1 & 2 & 1 & 2 & \\
\hline \multirow[t]{2}{*}{6.2} & \multirow{2}{*}{$\begin{array}{l}\text { During PNC, do you provide } \\
\text { information or counseling to } \\
\text { women about HIV/AIDS? }\end{array}$} & \multicolumn{4}{|l|}{ Yes } & 1 & \\
\hline & & \multicolumn{4}{|l|}{ No } & 2 & end \\
\hline \multirow[t]{3}{*}{6.3} & \multirow{3}{*}{$\begin{array}{l}\text { Does this health facility have } \\
\text { guidelines on PMTCT of HIV? }\end{array}$} & \multicolumn{4}{|l|}{ Yes } & 1 & \\
\hline & & \multicolumn{4}{|l|}{ No } & 2 & 6.6 \\
\hline & & \multicolumn{4}{|l|}{ Don't know } & 98 & 6.6 \\
\hline \multirow[t]{3}{*}{6.5} & \multirow{3}{*}{$\begin{array}{l}\text { How well do you know these } \\
\text { guidelines? }\end{array}$} & \multicolumn{4}{|l|}{ Very well } & 1 & \\
\hline & & \multicolumn{4}{|l|}{ Fairly well } & 2 & \\
\hline & & \multicolumn{4}{|l|}{ Not well } & 3 & \\
\hline \multirow[t]{6}{*}{6.6} & \multirow{6}{*}{$\begin{array}{l}\text { Please describe the four pillars } \\
\text { (prongs) of PMTCT. }\end{array}$} & Primary prevent & ion of & infection & & 1 & \\
\hline & & $\begin{array}{l}\text { Prevention of un } \\
\text { HIV-positive won }\end{array}$ & $\begin{array}{l}\text { intende } \\
\text { nen }\end{array}$ & regnancie & among & 2 & \\
\hline & & $\begin{array}{l}\text { Prevention of HI } \\
\text { women to their c }\end{array}$ & $\begin{array}{l}V \text { trans } \\
\text { hildrer }\end{array}$ & ion from 1 & IV-infected & 3 & \\
\hline & & $\begin{array}{l}\text { Treatment, care, } \\
\text { women and their }\end{array}$ & $\begin{array}{l}\text { and si } \\
\text { famili }\end{array}$ & rt of HIV & nfected & 4 & \\
\hline & & Other: & & & & 5 & \\
\hline & & Don't know & & & & 98 & \\
\hline 6.7 & What counseling do you & Do not give any & counse & & & 1 & \\
\hline & give to all postnatal clients & Routine testing a & nd cou & ing for $\mathrm{HI}$ & & 2 & \\
\hline & $\begin{array}{l}\text { for PMTCT of HIV during the } \\
\text { postnatal period? }\end{array}$ & $\begin{array}{l}\text { Avoid STls by us } \\
\text { faithful partner. }\end{array}$ & ing con & is and ha & ing a & 3 & \\
\hline & . & $\begin{array}{l}\text { Avoid mother's H } \\
\text { sex. }\end{array}$ & IIV infe & n by prac & cing safer & 4 & \\
\hline & Interviewer: Mark all relevant & Encourage partn & er test & & & 5 & \\
\hline & responses. & Other: & & & & 6 & \\
\hline 6.8 & What counseling do you & Do not give any & counse & & & 1 & \\
\hline & give to HIV-positive clients & Exclusive breast & eedinc & the first & months & 2 & \\
\hline & $\begin{array}{l}\text { for PMTCT of HIV during the } \\
\text { postnatal period? }\end{array}$ & $\begin{array}{l}\text { Exclusive breast } \\
\text { breastfeeding a } \\
\text { possible (if bab) }\end{array}$ & $\begin{array}{l}\text { eeding } \\
\text { s soon } \\
\text { is less }\end{array}$ & $\begin{array}{l}\text { opping al } \\
\text { eplaceme } \\
\text { in } 6 \text { montr }\end{array}$ & $\begin{array}{l}\text { f feeding is } \\
\text { old) }\end{array}$ & 3 & \\
\hline & $\begin{array}{l}\text { Interviewer: Mark all relevant } \\
\text { responses. }\end{array}$ & $\begin{array}{l}\text { If acceptable, fe } \\
\text { replacement fee } \\
\text { commercial form }\end{array}$ & $\begin{array}{l}\text { asible, } \\
\text { ding w } \\
\text { ula. }\end{array}$ & $\begin{array}{l}\text { e and aff } \\
\text { lome-pre }\end{array}$ & $\begin{array}{l}\text { rdable, use } \\
\text { ared or }\end{array}$ & 4 & \\
\hline & & If breastfeeding & keep & asts healt & & 5 & \\
\hline & & Explain that thei & $r$ babi & lould take & ARVs. & 6 & \\
\hline & & Explain that they & shoul & ke their $A$ & & 7 & \\
\hline & & $\begin{array}{l}\text { Tell them that loc } \\
\text { people, and the } \\
\text { blood-stained sc }\end{array}$ & $\begin{array}{l}\text { hia ca } \\
\text { efore } \\
\text { anitary }\end{array}$ & $\begin{array}{l}\text { use infect } \\
\text { should di } \\
\text { ds. }\end{array}$ & $\begin{array}{l}\text { on in other } \\
\text { pose of }\end{array}$ & 8 & \\
\hline & & $\begin{array}{l}\text { Visit HIV service } \\
\text { further assessme }\end{array}$ & $\begin{array}{l}52 \text { we } \\
\text { nt. }\end{array}$ & after deli & ery for & 9 & \\
\hline & & Mothers and pa & tners & Id practic & safer sex. & 10 & \\
\hline & & Other: & & & & 11 & \\
\hline
\end{tabular}




\begin{tabular}{|c|c|c|c|}
\hline 6.9 & $\begin{array}{l}\text { What kind of messages do you } \\
\text { give to HIV-positive mothers to }\end{array}$ & $\begin{array}{l}\text { Do not give any counseling. } \\
\text { Exclusive breastfeeding for the first } 6 \text { months }\end{array}$ & $\frac{1}{2}$ \\
\hline & promote safer breastfeeding? & $\begin{array}{l}\text { Exclusive breastfeeding, stopping all } \\
\text { breastfeeding as soon as replacement feeding is } \\
\text { possible (if baby is less than } 6 \text { months old) }\end{array}$ & 3 \\
\hline & $\begin{array}{l}\text { Interviewer: Mark all the } \\
\text { relevant responses. }\end{array}$ & $\begin{array}{l}\text { If acceptable, feasible, affordable, safe and } \\
\text { sustainable, use replacement feeding with home- } \\
\text { prepared or commercial formula. }\end{array}$ & 4 \\
\hline & & $\begin{array}{l}\text { Early weaning and replacement feeding at } \\
\text { around } 6 \text { months }\end{array}$ & 5 \\
\hline & & $\begin{array}{l}\text { Ensure baby is attached and positioned to breast } \\
\text { properly to prevent nipple problems. }\end{array}$ & 6 \\
\hline & & $\begin{array}{l}\text { Promptly seek medical attention for breast } \\
\text { problems. }\end{array}$ & 7 \\
\hline & & Other: & 8 \\
\hline 6.10 & $\begin{array}{l}\text { What are the conditions } \\
\text { necessary for replacement }\end{array}$ & $\begin{array}{l}\text { It has to be acceptable, feasible, affordable, } \\
\text { safe and sustainable. }\end{array}$ & 1 \\
\hline & feeding to be a viable option & Other: & 2 \\
\hline & mothers? & Don't know & 98 \\
\hline 6.11 & What special & Do not give any counseling. & 1 \\
\hline & recommendations/information & Use sit baths to encourage healing. & 2 \\
\hline & $\begin{array}{l}\text { do you provide to postnatal } \\
\text { women who are HIV positive }\end{array}$ & $\begin{array}{l}\text { Treat preexisting vulval warts/abscess } \\
\text { aggressively. }\end{array}$ & 3 \\
\hline & $\begin{array}{l}\text { regarding their personal care } \\
\text { and the care of their babies? }\end{array}$ & $\begin{array}{l}\text { Advise against unprotected early penetrative sex } \\
\text { after delivery. }\end{array}$ & 4 \\
\hline & & $\begin{array}{l}\text { Monitor and seek care early for opportunistic } \\
\text { infections. }\end{array}$ & 5 \\
\hline & & Counseling on available support & 6 \\
\hline & & Regular monitoring of CD4 count & 7 \\
\hline & & Regular checkups (6 monthly) & 8 \\
\hline & & Availability and use of ARVs & 9 \\
\hline & & Cotrimoxazole prophylaxis for newborn & 10 \\
\hline & & Cleanliness & 11 \\
\hline & & Avoid stressful situations. & 12 \\
\hline & & Eat a balanced diet. & 13 \\
\hline & & Other: & 14 \\
\hline 6.12 & What special recommendations & Do not provide special recommendations. & 1 \\
\hline & $\begin{array}{l}\text { do you provide to postnatal } \\
\text { women who are HIV positive }\end{array}$ & $\begin{array}{l}\text { Remind them that a future pregnancy can have } \\
\text { significant health risks for them and their baby. }\end{array}$ & 2 \\
\hline & regarding FP? & $\begin{array}{l}\text { Recommend that they wait before another } \\
\text { pregnancy. }\end{array}$ & 3 \\
\hline & Interviewer: Mark all relevant & $\begin{array}{l}\text { Counsel them on safer sex, including the use of } \\
\text { the condom. }\end{array}$ & 4 \\
\hline & & $\begin{array}{l}\text { Tell them that the IUD is not recommended for } \\
\text { women with AIDS who are not in ART. }\end{array}$ & 5 \\
\hline & & Recommend that they not use LAM. & 6 \\
\hline & & $\begin{array}{l}\text { Recommend that they always use a condom in } \\
\text { addition to other FP methods. }\end{array}$ & 7 \\
\hline & & $\begin{array}{l}\text { Tell them that spermicides are not appropriate } \\
\text { for HIV-positive women. }\end{array}$ & 8 \\
\hline & & $\begin{array}{l}\text { If they are taking pills for tuberculosis or ART } \\
\text { (rifampin), contraceptive pills, monthly injectables, } \\
\text { and implants may not be appropriate for them. }\end{array}$ & 9 \\
\hline & & Other: & 10 \\
\hline
\end{tabular}




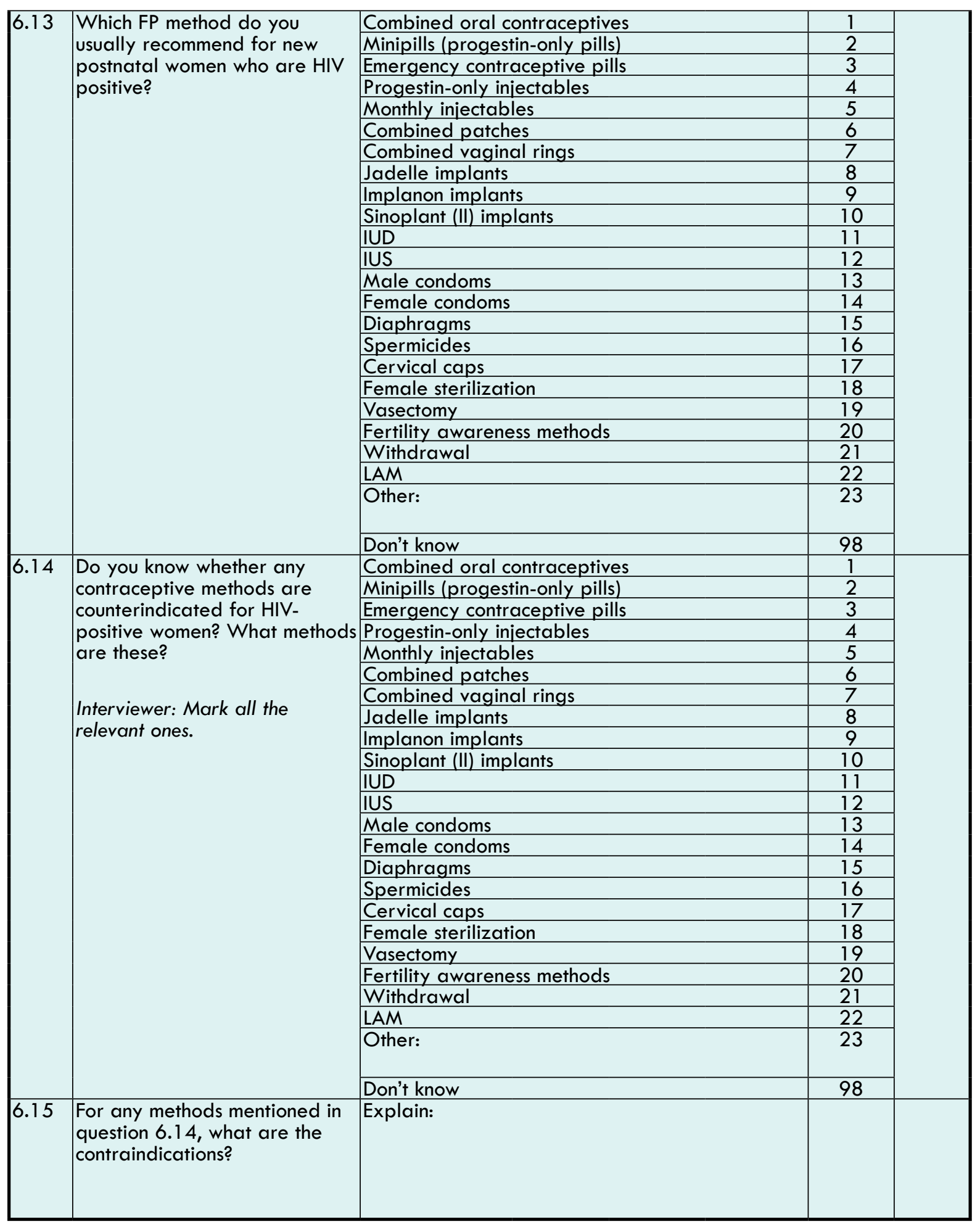




\section{Data collection instruments for family planning \\ in postabortion care services}

This section contains the four basic instruments for conducting an AIM on the FP component of postabortion care (PAC) services. Instruments are presented in the following order:

\section{A) Inventory for facilities available and services provided at the facility \\ B) Observation guide \\ C) Questionnaire for clients' exit interviews \\ D) Questionnaire for providers' interviews}

Since some may be interested in using AIM to gather information exclusively about the FP component of PAC services, while others may want to take advantage of a research team already visiting the facility to obtain information about the general quality of PAC, the instruments below contain questions that are relevant for both purposes. The first two modules of the inventory and the observation guide, and the first three modules of the provider's and client's interviews are designed to serve as a questionnaire that can easily be adapted to any study that focuses exclusively on measuring the quality of $\mathrm{FP}$ services in PAC.

All the modules that follow the one labeled "FP in Postabortion Care Services" are designed to assess different components of the quality of PAC services. Those interested in this aspect can adapt the whole instruments to their own context. Some of the questions in these modules are relevant only in certain contexts or for specific objectives, such as those that refer to hours of operation or the questions about costs. These optional questions are shaded for easy identification.

We recommend that only those questions that are directly linked to the objectives of each study (as defined by the researchers) are included in the final questionnaires. Otherwise, research teams risk wasting money and time collecting too much information that will not be used.

\section{A. Inventory for facilities available and services provided at the facility}

\section{INSTRUCTIONS TO DATA}

COLLECTOR: This inventory should be completed by observing the facilities that are available and having discussions with the person in charge of PAC on the day of the visit. For some questions, you may also have to talk to the person in charge of FP.

For some of the questions in this instrument, you will have to observe directly the availability of equipment, supplies, and infrastructure. Ask the clinic staff member who is assisting you to direct you to the room, laboratory, or storage area that you need to verify the availability of each item. In all cases, you should verify that the items exist by actually observing them yourself; if you are not able to observe them, then code accordingly. Remember that the objective of this instrument is to identify equipment and facilities that currently exist and are in working order and not to evaluate the performance of the staff or the clinic. For each item, circle the code of the most suitable response or describe, as appropriate. Before beginning, read the following greeting when you meet with the person who will help you fill this instrument:

GREETING: Good morning. My name is , and I work for We

are currently doing a study about the way that family planning services are being integrated with PAC in the country and the issues that arise with integration. This is not an evaluation of this facility or of the people who give us this information. We are visiting a number of facilities and all the information you give me will be confidential. No one will know what you said. Are you willing to assist? 
1. Facility identification

\begin{tabular}{|c|c|c|c|}
\hline No. & QUESTIONS & \multicolumn{2}{|l|}{ CODING CATEGORIES } \\
\hline 1.1 & Date of observations & \multicolumn{2}{|l|}{ (Day/Month/ Year) } \\
\hline \multirow{9}{*}{\begin{tabular}{|l|}
1.2 \\
1.3 \\
1.4 \\
\end{tabular}} & \multicolumn{3}{|l|}{ Facility name } \\
\hline & \multicolumn{3}{|l|}{ City or locality } \\
\hline & \multirow[t]{7}{*}{ Type of facility } & Hospital & 1 \\
\hline & & Health center with maternity ward & 2 \\
\hline & & $\begin{array}{l}\text { Health center without maternity } \\
\text { ward }\end{array}$ & 3 \\
\hline & & Health post with maternity ward & 4 \\
\hline & & $\begin{array}{l}\text { Health post without maternity } \\
\text { ward }\end{array}$ & 5 \\
\hline & & Dispensary & 6 \\
\hline & & Other: & 7 \\
\hline \multirow[t]{4}{*}{1.5} & \multirow{4}{*}{ Type of sector } & Government & 1 \\
\hline & & NGO & 2 \\
\hline & & Private & 3 \\
\hline & & Other: & 4 \\
\hline \multirow[t]{4}{*}{1.6} & \multirow[t]{4}{*}{ Result of the inventory } & Complete & 1 \\
\hline & & Incomplete & 2 \\
\hline & & Refused & 3 \\
\hline & & Other: & 4 \\
\hline
\end{tabular}

\section{FP services in PAC}

No. QQUESTIONS

2.1 Is (read 1 to 3 ) available to clients in this health facility? How many days per week are (read 1 to 3 ) services offered?

1) FP counseling

2) Contraceptives

3) Antenatal care

2.2 Do the hours of operation of FP services coincide with the hours of operation and discharge of PAC clients?

\section{CODING CATEGORIES}

GO TO

2.3 How many providers and of which type (qualifications) are assigned to work in PAC in this facility? Of the staff involved in PAC, how many have as one of their responsibilities giving FP to PAC clients?

Type of staff

PAC

PAC providers that give

1) Medical specialists

2) General practitioners

3) Medical residents

4) Medical interns

5) Trained midwives

6) Professional nurse

7) Auxiliary nurse

8) Nursing student

9) Social worker

10) Other 1:

11) Other 2: FP to PAC clients 


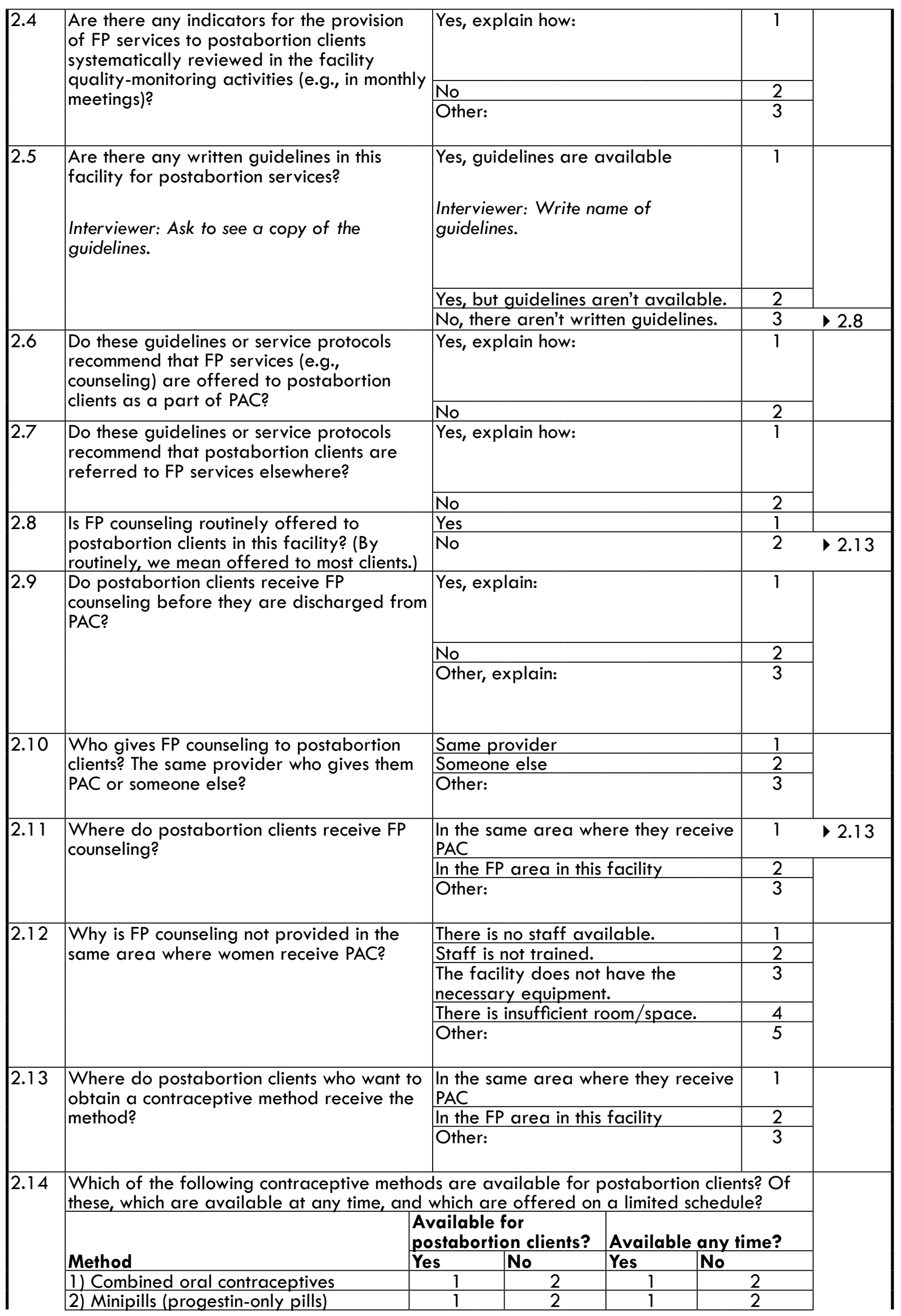


3) Emergency contraceptive pills

4) Progestin-only injectables (injection

every 2 or 3 months)

5) Monthly injectables

6) Combined patches

7) Combined vaginal rings

8) Jadelle implants

9) Implanon implants

10) Sinoplant (II) implants

11) IUD

12) IUS

13) Male condoms

14) Female condoms

15) Diaphragms

16) Spermicides

17) Cervical caps

18) Female sterilization

19) Vasectomy

20) Fertility awareness methods

21) Withdrawal

22) Other:

2.15 Are postabortion clients who are interested in receiving a contraceptive method that is not available in the same area where they receive PAC routinely referred to FP services in this facility or to another place where they can get their desired method?

Interviewer: Obtain the following information from

the service statistics.

Number of PAC clients

Number of PAC clients who received FP

counseling

Number of PAC clients who received a

contraceptive before discharge

Number of PAC clients who were referred to FP services

2.17 On the date of visit, which of the following contraceptives were available for PAC clients?

1) Combined oral contraceptives

2) Progestin-only pills

3) Emergency contraceptive pills (prepacked)

4) Emergency contraceptive pills (not prepacked)

5) Progestin-only injectables

6) Monthly injectables

7) Combined patches

8) Combined vaginal rings

9) Jadelle implants

10) Implanon implants

11) Sinoplant (II) implants

12) IUD

13) IUS

14) Male condoms

15) Female condoms

16) Diaphragms

17) Spermicides

18) Female sterilization

19) Vasectomy

\begin{tabular}{|l|l|l|l|}
\hline 1 & 2 & 1 & 2 \\
\hline 1 & 2 & 1 & 2 \\
\hline 1 & 2 & 1 & 2 \\
\hline 1 & 2 & 1 & 2 \\
\hline 1 & 2 & 1 & 2 \\
\hline 1 & 2 & 1 & 2 \\
\hline 1 & 2 & 1 & 2 \\
\hline 1 & 2 & 1 & 2 \\
\hline 1 & 2 & 1 & 2 \\
\hline 1 & 2 & 1 & 2 \\
\hline 1 & 2 & 1 & 2 \\
\hline 1 & 2 & 1 & 2 \\
\hline 1 & 2 & 1 & 2 \\
\hline 1 & 2 & 1 & 2 \\
\hline 1 & 2 & 1 & 2 \\
\hline 1 & 2 & 1 & 2 \\
\hline 1 & 2 & 1 & 2 \\
\hline 1 & 2 & 1 & 2 \\
\hline 1 & 2 & 1 & 2 \\
& & & \\
\hline
\end{tabular}

Yes, referred to FP services in this facility

Yes, referred elsewhere (specify)

No

Other:

\begin{tabular}{|l|l|l|} 
Last 12 & Last 6 & Last
\end{tabular} months months month

Info not available

1

\begin{tabular}{|l|l|l|l|}
\hline & & & \\
\end{tabular}

\begin{tabular}{|l|l|l|l|}
\hline & & & \\
\hline & & & \\
\hline
\end{tabular}

\section{Available}

Not available

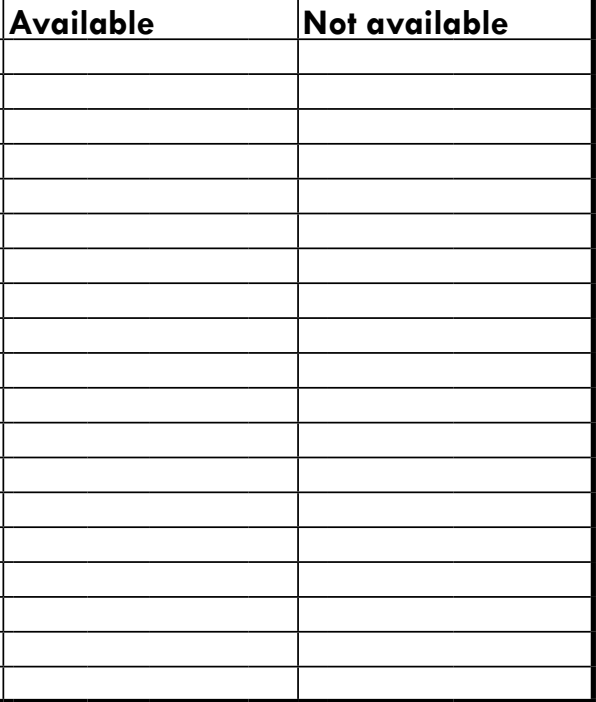


3. Description of the service area

\begin{tabular}{|c|c|c|}
\hline No. & QUESTIONS & CODING CATEGORIES \\
\hline 3.1 & Area & \\
\hline 3.2 & Population & \\
\hline 3.3 & Number of women in reproductive age & \\
\hline 3.4 & Health facilities operating in the district & Number of hospitals: \\
\hline & & Number of health centers: \\
\hline & & Number of health posts: \\
\hline & & Number of dispensaries: \\
\hline & & Number of other facilities: \\
\hline & & $\begin{array}{l}\text { Interviewer: Specify what is included in this } \\
\text { category. }\end{array}$ \\
\hline
\end{tabular}

\section{Hours of operation}

\begin{tabular}{|c|c|c|c|}
\hline No. & QUESTIONS & CODING CATEGORIES & \\
\hline 4.1 & Routinely, how many days per week is the facility open? & Days: & \\
\hline \multirow[t]{3}{*}{4.2} & What are the opening and closing hours at this facility? & Opening time & \\
\hline & & Closing time & \\
\hline & & (Hour : Minutes) & \\
\hline \multirow[t]{2}{*}{4.3} & Does the facility provide PAC 24 hours a day? & Yes & 1 \\
\hline & & No & 2 \\
\hline \multirow[t]{2}{*}{4.4} & Is there a nurse or doctor present at the facility at all & Yes & 1 \\
\hline & times? ( 24 hours/day) & No & 2 \\
\hline \multirow[t]{2}{*}{4.5} & Is there a nurse or doctor available on call at all times & Yes & 1 \\
\hline & after hours? & No & 2 \\
\hline
\end{tabular}

\section{Services available/Staff}

\begin{tabular}{|c|c|c|c|c|}
\hline \multirow{4}{*}{\begin{tabular}{|l} 
No. \\
5.1
\end{tabular}} & QUESTIONS & \multicolumn{3}{|l|}{ CODING CATEGORIES } \\
\hline & Do you have staff shortages in (read 1 to 2 ) services? & Yes & No & \\
\hline & 1) PAC & 1 & \multicolumn{2}{|l|}{2} \\
\hline & 2) $\mathrm{FP}$ & 1 & \multicolumn{2}{|l|}{2} \\
\hline \multirow[t]{10}{*}{5.2} & \multirow[t]{10}{*}{ What types of staff shortages are most critical? } & \multicolumn{2}{|l|}{ Medical specialists } & 1 \\
\hline & & \multicolumn{2}{|l|}{ General practitioners } & 2 \\
\hline & & \multicolumn{2}{|l|}{ Medical residents } & 3 \\
\hline & & \multicolumn{2}{|l|}{ Medical interns } & 4 \\
\hline & & \multicolumn{2}{|l|}{ Trained midwives } & 5 \\
\hline & & \multicolumn{2}{|l|}{ Professional nurse } & 6 \\
\hline & & \multicolumn{2}{|l|}{ Auxiliary nurse } & 7 \\
\hline & & \multicolumn{2}{|l|}{\begin{tabular}{|l|} 
Nursing student \\
Social
\end{tabular}} & 8 \\
\hline & & \multirow{2}{*}{\multicolumn{2}{|c|}{\begin{tabular}{|l} 
Social worker \\
Other:
\end{tabular}}} & 9 \\
\hline & & & & 10 \\
\hline
\end{tabular}

\section{Supervision}

\begin{tabular}{|c|c|c|c|c|}
\hline No. & QUESTIONS & CODING CATEGORIES & & GO TO \\
\hline \multirow[t]{5}{*}{6.1} & \multirow{5}{*}{$\begin{array}{l}\text { How often do formal meetings to discuss facility } \\
\text { management/administrative issues take place? }\end{array}$} & Monthly & 1 & \\
\hline & & Quarterly & 2 & \\
\hline & & Semi-annually & 3 & \\
\hline & & Other: & 4 & \\
\hline & & No formal management meetings & 5 & 6.3 \\
\hline \multirow[t]{3}{*}{6.2} & \multirow[t]{2}{*}{ Is an official record of meetings maintained? } & Yes, record seen & 1 & \\
\hline & & Yes, record not seen & 2 & \\
\hline & $\begin{array}{l}\text { Interviewer: If yes, ask to see some record from } \\
\text { most recent meeting. }\end{array}$ & No official record of meetings & 3 & \\
\hline \multirow[t]{3}{*}{6.3} & \multirow{3}{*}{$\begin{array}{l}\text { Does this facility have any system for } \\
\text { determining clients' opinions about the health } \\
\text { facility or services? }\end{array}$} & Yes & 1 & \\
\hline & & No & 2 & 6.6 \\
\hline & & Unsure & 3 & 6.6 \\
\hline
\end{tabular}




\begin{tabular}{|c|c|c|c|c|}
\hline 6.4 & In the past 3 months, have any changes & Yes & 1 & \\
\hline & $\begin{array}{l}\text { been made in the facility as a result of client } \\
\text { opinion? }\end{array}$ & No & 2 & \\
\hline 6.5 & Does this facility have a method for monitoring & Yes & 1 & \\
\hline & the quality of care provided to clients? & No & 2 & 6.8 \\
\hline 6.6 & What is done to monitor quality of care? & & & \\
\hline 6.7 & Are there any indicators for PAC systematically & Yes & 1 & \\
\hline & reviewed in these quality-monitoring activities? & No & 2 & \\
\hline & & Other: & 3 & \\
\hline 6.8 & Who is responsible for reviewing findings & Individual service provision staff & 1 & \\
\hline & and taking action relative to quality of care & Individual supervisors & 2 & \\
\hline & activities? & Internal management/quality team & 3 & \\
\hline & & External management team & 4 & \\
\hline & Interviewer: Mark all that apply. & Other: & 5 & \\
\hline 6.9 & When was the last time an external supervisor & Within the last 6 months & 1 & \\
\hline & $\begin{array}{l}\text { (someone from outside this facility) visited the } \\
\text { facility? }\end{array}$ & More than 6 months ago & 2 & $\begin{array}{l}\text { next } \\
\text { section }\end{array}$ \\
\hline & & No external supervision & 3 & $\begin{array}{l}\text { next } \\
\text { section }\end{array}$ \\
\hline 6.10 & The last time within the last 6 months that a & Check records? & 1 & \\
\hline & supervisor from outside the facility visited, did & Discuss problems? & 2 & \\
\hline & the supervisor do the following. & $\begin{array}{l}\text { Discuss policy/administrative } \\
\text { issues? }\end{array}$ & 3 & \\
\hline & Interviewer: Read options and mark all that & $\begin{array}{l}\text { Discuss technical protocols/ } \\
\text { practice? }\end{array}$ & 4 & \\
\hline & apply. Ask "Something else?" & Hold an official staff meeting? & 5 & \\
\hline & & $\begin{array}{l}\text { Observe individual staff providing } \\
\text { services? }\end{array}$ & 6 & \\
\hline & & Other: & 7 & \\
\hline
\end{tabular}

7. PAC quality

\begin{tabular}{|c|c|c|c|c|c|c|}
\hline \multirow{8}{*}{$\begin{array}{l}\text { No. } \\
7.1\end{array}$} & QUESTIONS & \multicolumn{4}{|c|}{ CODING CATEGORIES } & GO TO \\
\hline & \multicolumn{5}{|c|}{$\begin{array}{l}\text { Which of the following services are routinely offered to postabortion clients in this facility? } \\
\text { (By routinely, we mean offered to every client.) If a service is not routinely offered in } \\
\text { this facility, are postabortion clients referred to a different health facility to obtain this } \\
\text { service? } \\
\text { Interviewer: Read options. }\end{array}$} & \\
\hline & \multirow{2}{*}{\begin{tabular}{|l|} 
Service \\
FP \\
\end{tabular}} & Offered & Referred & \multicolumn{2}{|c|}{$\begin{array}{l}\text { Not offered } \\
\text { or referred }\end{array}$} & \\
\hline & & 1 & 2 & \multicolumn{2}{|c|}{3} & \\
\hline & HIV/AIDS voluntary counseling & 1 & 2 & \multicolumn{2}{|c|}{3} & \\
\hline & HIV/AIDS testing & 1 & 2 & \multicolumn{2}{|c|}{3} & \\
\hline & STI screening and treatment & 1 & 2 & \multicolumn{2}{|c|}{3} & \\
\hline & Infertility treatment & 1 & 2 & \multicolumn{2}{|c|}{3} & \\
\hline \multirow[t]{4}{*}{7.2} & \multirow{4}{*}{\multicolumn{2}{|c|}{$\begin{array}{l}\text { In the cases where postabortion clients are referred } \\
\text { elsewhere for some services, are they given a referral slip } \\
\text { or coupon with information such as the name of the clinic to } \\
\text { which they should go, the service they need, or any other } \\
\text { information? }\end{array}$}} & \multirow{2}{*}{\multicolumn{3}{|c|}{$\begin{array}{l}\text { Yes, form seen } \\
\text { Yes, form not seen } \\
\text { No }\end{array}$}} & \\
\hline & & & & & & \\
\hline & & & \multirow{2}{*}{\multicolumn{2}{|c|}{ No }} & 3 & 7.4 \\
\hline & & & & & & \\
\hline
\end{tabular}




\begin{tabular}{|c|c|c|c|c|}
\hline \multirow[t]{5}{*}{7.3} & \multirow{5}{*}{$\begin{array}{l}\text { What information is included in the referral slip or coupon? } \\
\text { Interviewer: Mark all that apply. }\end{array}$} & Name of patient & 1 & \\
\hline & & $\begin{array}{l}\text { Name of referring } \\
\text { clinic }\end{array}$ & 2 & \\
\hline & & $\begin{array}{l}\text { Name of clinic } \\
\text { where service should } \\
\text { be provided }\end{array}$ & 3 & \\
\hline & & $\begin{array}{l}\text { Services that should } \\
\text { be received }\end{array}$ & 4 & \\
\hline & & Other: & 5 & \\
\hline \multirow[t]{2}{*}{7.4} & \multirow{2}{*}{$\begin{array}{l}\text { Does staff working with postabortion clients in this facility } \\
\text { have a directory or list of referral services? }\end{array}$} & Yes & 1 & \\
\hline & & No & 2 & $\begin{array}{l}\text { next } \\
\text { section }\end{array}$ \\
\hline \multirow[t]{2}{*}{7.5} & \multirow{2}{*}{$\begin{array}{l}\text { Is this referral list easily accessible to all staff working with } \\
\text { postabortion clients? }\end{array}$} & Yes & 1 & \\
\hline & & No & 2 & \\
\hline
\end{tabular}

\section{Organization of PAC services}

\begin{tabular}{|c|c|c|c|c|c|}
\hline \multirow{5}{*}{\begin{tabular}{|l|} 
No. \\
8.1
\end{tabular}} & QUESTIONS & \multicolumn{3}{|c|}{ CODING CATEGORIES } & GO TO \\
\hline & $\begin{array}{l}\text { What uterine evacuation techniques are used in } \\
\text { this health facility to treat postabortion clients? }\end{array}$ & \multicolumn{2}{|c|}{$\begin{array}{l}\text { Manual Vacuum Aspiration } \\
\text { (MVA) }\end{array}$} & 1 & \\
\hline & & \multicolumn{2}{|c|}{ Electric vacuum aspiration } & 2 & \\
\hline & & \multicolumn{2}{|c|}{$\begin{array}{l}\text { Dilatation and Curettage } \\
(D \& C)\end{array}$} & 3 & \\
\hline & & \multicolumn{2}{|c|}{ Other: } & 4 & \\
\hline \multirow[t]{4}{*}{8.2} & $\begin{array}{l}\text { Does the facility have providers trained in uterine } \\
\text { evacuation in the three shifts? }\end{array}$ & Yes & \multicolumn{2}{|l|}{ No } & \\
\hline & Morning & 1 & \multicolumn{2}{|c|}{2} & \\
\hline & Afternoon & 1 & \multicolumn{2}{|c|}{2} & \\
\hline & Night & 1 & \multicolumn{2}{|c|}{2} & \\
\hline \multirow[t]{2}{*}{8.3} & \multirow[t]{2}{*}{ Does this facility have providers trained in MVA? } & \multirow{2}{*}{\multicolumn{2}{|c|}{\begin{tabular}{|l|} 
Yes \\
No
\end{tabular}}} & 1 & \\
\hline & & & & 2 & 8.5 \\
\hline \multirow[t]{4}{*}{8.4} & $\begin{array}{l}\text { Does the facility have providers trained in MVA in } \\
\text { the three shifts? }\end{array}$ & Yes & \multicolumn{2}{|l|}{ No } & \\
\hline & Morning & 1 & \multicolumn{2}{|c|}{2} & \\
\hline & Afternoon & 1 & \multicolumn{2}{|c|}{2} & \\
\hline & Night & 1 & \multicolumn{2}{|c|}{2} & \\
\hline \multirow[t]{2}{*}{8.5} & Can a postabortion client be discharged at any & \multicolumn{2}{|l|}{ Yes } & 1 & \\
\hline & time of day? & \multicolumn{2}{|l|}{ No } & 2 & \\
\hline \multirow[t]{2}{*}{8.6} & $\begin{array}{l}\text { What is the average hospital stay for postabortion } \\
\text { clients? }\end{array}$ & \multirow{2}{*}{\multicolumn{2}{|c|}{\begin{tabular}{|l} 
Minutes: \\
Hours: \\
Davs.
\end{tabular}}} & & \\
\hline & & & & & \\
\hline
\end{tabular}

\section{General infrastructure of the facility}

\begin{tabular}{|l|l|c|c|}
\hline No. & QUESTIONS & CODING CATEGORIES \\
\hline \multirow{5}{9}{ I.1 } & $\begin{array}{l}\text { Interviewer: Observe the conditions and infrastructure in the facility and } \\
\text { mark whether it has the following. }\end{array}$ & Yes & 1 \\
\hline & 1) Piped running water & 1 & 2 \\
\hline 2) Electricity & 1 & 2 \\
\hline 3) Working latrines/toilets for clients & 1 & 2 \\
\hline 4) Working phone/short wave radio & 1 & 2 \\
\hline $\begin{array}{l}\text { 5) Transport vehicle in working order or standing arrangements for } \\
\text { transport in the case of emergencies }\end{array}$ & 1 & 2 \\
\hline $\begin{array}{l}\text { 6) Clean facilities (e.g., the floors are swept, there is no dust in the } \\
\text { desks) }\end{array}$ & 1 & 2 \\
\hline 7) Enough chairs or benches in waiting areas & 1 & 2 \\
\hline $\begin{array}{l}\text { 8) Waiting area for clients where they are protected from the sun, rain } \\
\text { and snow }\end{array}$ & \\
\hline
\end{tabular}


10. PAC examination rooms

\begin{tabular}{|c|c|c|c|c|}
\hline No. & QUESTIONS & CODING CATI & GORIES & \\
\hline $\begin{array}{l}\text { Interv } \\
\text { items, }\end{array}$ & $\begin{array}{l}\text { wer: Ask to see the area where women with obstetric emergencies a } \\
\text { heck whether the item is in the area or in an adjacent room. }\end{array}$ & first examined. & or the fo & \\
\hline 10.1 & Describe the setting for the examination room: & Private room & & 1 \\
\hline & & $\begin{array}{l}\text { Room with othe } \\
\text { with separatin }\end{array}$ & $\begin{array}{l}\text { people } \\
\text { barrier }\end{array}$ & 2 \\
\hline & & $\begin{array}{l}\text { Room with othe } \\
\text { and no visual }\end{array}$ & $\begin{array}{l}\text { people } \\
\text { arrier }\end{array}$ & 3 \\
\hline 10.2 & Materials and equipment required for hand washing: & Yes & No & \\
\hline & 1) Clean water supply & 1 & 2 & \\
\hline & 2) Soap & 1 & 2 & \\
\hline & 3) Nail brush or stick & 1 & 2 & \\
\hline & 4) Clean towels & 1 & 2 & \\
\hline 10.3 & $\begin{array}{l}\text { Materials and equipment required to examine women in working } \\
\text { order: }\end{array}$ & Yes & No & \\
\hline & 1) Spot light source (flashlight or examination light accepted) & 1 & 2 & \\
\hline & 2) Examination couch for gynecological exam & 1 & 2 & \\
\hline 10.4 & What is the most commonly used method to sterilize/disinfect the & Boiling & & 1 \\
\hline & specula/forceps? & Autoclave & & 2 \\
\hline & & Heat sterilizer & & 3 \\
\hline & & Use disposabl & only & 4 \\
\hline & & Using bleach & & 5 \\
\hline & & Other: & & 6 \\
\hline
\end{tabular}

\section{PAC treatment rooms and equipment}

\begin{tabular}{|c|c|c|c|c|}
\hline No. & QUESTIONS & CODING CA & & \\
\hline $\begin{array}{l}\text { Interv } \\
\text { client }\end{array}$ & $\begin{array}{l}\text { wer: Ask to see the area where the therapeutic procedur } \\
\text { For the following items, check whether the item is in the }\end{array}$ & $\begin{array}{l}\text { S }(D \& C \text { or } M \\
\text { rea or in an a }\end{array}$ & $\begin{array}{l}\text { olace for po } \\
\text { om. }\end{array}$ & rtion \\
\hline 11.1 & Describe the setting for the examination room: & Private room & & 1 \\
\hline & & $\begin{array}{l}\text { Room with of } \\
\text { separating } b\end{array}$ & le with & 2 \\
\hline & & $\begin{array}{l}\text { Room with of } \\
\text { visual barrie }\end{array}$ & le and no & 3 \\
\hline 11.2 & Materials and equipment required for hand washing: & Yes & No & \\
\hline & (1) Clean water supply & 1 & $+r$ & \\
\hline & (2) Soap & 1 & 2 & \\
\hline & (3) Nail brush or stick & 1 & 2 & \\
\hline & (4) Clean towels & 1 & 2 & \\
\hline 11.3 & Instruments and equipment are in working order: & Yes & No & \\
\hline & (1) Instrument table & 1 & 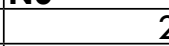 & \\
\hline & (2) Gynecological exam table & 1 & 2 & \\
\hline & (3) Light & 1 & 2 & \\
\hline & (4) Uterine forceps & 1 & 2 & \\
\hline & (5) Ligature forces & 1 & 2 & \\
\hline & (6) Speculum & 1 & 2 & \\
\hline & (7) MVA instruments & 1 & 2 & \\
\hline & (8) D\&C instruments & 1 & 2 & \\
\hline
\end{tabular}

\section{IEC materials}

\begin{tabular}{l|l|l}
\hline No. & QUESTIONS & CODING CATEGORIES
\end{tabular}

Interviewer: Verify that the following materials are available in the room where PAC clients receive counseling.

\begin{tabular}{|l|l|r|c|}
\hline 12.1 & 1) Visual aids for teaching about: & Yes & No \\
\cline { 2 - 3 } & 2) Different FP methods & 1 & 2 \\
\cline { 2 - 3 } & 3) Model for demonstrating condom use & 1 & 2 \\
\cline { 2 - 3 } & 4) PAC & 1 & 2 \\
\cline { 2 - 4 } & 5) STIs & 1 & 2 \\
\cline { 2 - 4 } & 6) HIV/AIDS & 1 & 2 \\
\hline & Information booklets/leaflets for clients to take home: & No \\
\cline { 2 - 4 } & 1) Different FP methods & 1 & 2 \\
\cline { 2 - 4 } & 2) Model for demonstrating condom use & 1 & 2 \\
\cline { 2 - 4 } & 3) PAC & 1 & 2 \\
\cline { 2 - 4 } & 4) STls & 1 & 2 \\
\hline
\end{tabular}


13. Record keeping

\begin{tabular}{|c|c|c|c|c|c|}
\hline \multirow{2}{*}{\begin{tabular}{|l|} 
No. \\
13.1
\end{tabular}} & \multirow{3}{*}{$\begin{array}{l}\text { QUESTIONS } \\
\text { Is there a daily activity record for PAC in this facility? }\end{array}$} & \multicolumn{4}{|c|}{ CODING CATEGORIES } \\
\hline & & \multicolumn{3}{|l|}{ Yes } & 1 \\
\hline & & \multicolumn{3}{|l|}{ No } & 2 \\
\hline \multirow[t]{5}{*}{13.2} & $\begin{array}{l}\text { Interviewer: Complete this information using the available } \\
\text { statistics from the last } 12 \text { months. }\end{array}$ & $\begin{array}{l}\text { Last } 12 \\
\text { months }\end{array}$ & $\begin{array}{l}\text { Lasł } 6 \\
\text { months }\end{array}$ & $\begin{array}{l}\text { Last } \\
\text { month }\end{array}$ & $\begin{array}{l}\text { Info not } \\
\text { available }\end{array}$ \\
\hline & Number of all postabortion clients & & & & \\
\hline & Number of postabortion clients treated with MVA & & & & \\
\hline & Number of postabortion clients treated with D\&C & & & & \\
\hline & Number of postabortion clients treated with diaital & & & & \\
\hline
\end{tabular}

\section{Costs}

\begin{tabular}{|l|l}
\hline No. & QUESTIONS \\
\hline
\end{tabular}

\begin{tabular}{|l|l}
\hline 14.1 & What are clients charged for obtaining the following services, commodities, tests, or procedures?
\end{tabular}

Interviewer: Ask questions 14.1 to 14.3 and register answers in the table below.

14.2 Is there a waiver or exemption policy for women who cannot pay?

14.3 Who is exempted from paying these fees?

Service or commodity

Treatment of incomplete abortion

FP counseling

Combined oral contraceptives

Minipills (progestin-only pills)

Emergency contraceptive pills

Progestin-only injectables (injection

every 2 or 3 months)

Monthly injectables

Combined patches

Combined vaginal rings

Jadelle implants

Implanon implants

Sinoplant (II) implants

IUD

IUS

Male condoms

Female condoms

Diaphragms

Spermicides

Cervical caps

Female sterilization

Vasectomy

HIV/AIDS testing

Syphilis testing

Other STI testing

\begin{tabular}{|c|c|c|c|}
\hline \multirow{2}{*}{$\begin{array}{l}14.1 \\
\text { Charge in local } \\
\text { currency }\end{array}$} & \multicolumn{2}{|c|}{$\begin{array}{l}14.2 \\
\text { Is there a waiver or } \\
\text { exemption policy? }\end{array}$} & \multirow{2}{*}{$\begin{array}{l}14.3 \\
\text { Who is exempted from } \\
\text { paying these fees? }\end{array}$} \\
\hline & & & \\
\hline$\$$ & 1 & 2 & \\
\hline$\$$ & 1 & 2 & \\
\hline$\$$ & 1 & 2 & \\
\hline$\$$ & 1 & 2 & \\
\hline$\$$ & 1 & 2 & \\
\hline$\$$ & 1 & 2 & \\
\hline$\$$ & 1 & 2 & \\
\hline$\$$ & 1 & 2 & \\
\hline$\$$ & 1 & 2 & \\
\hline$\$$ & 1 & 2 & \\
\hline$\$$ & 1 & 2 & \\
\hline$\$$ & 1 & 2 & \\
\hline$\$$ & 1 & 2 & \\
\hline$\$$ & 1 & 2 & \\
\hline$\$$ & 1 & 2 & \\
\hline$\$$ & 1 & 2 & \\
\hline$\$$ & 1 & 2 & \\
\hline$\$$ & 1 & 2 & \\
\hline$\$$ & 1 & 2 & \\
\hline$\$$ & 1 & 2 & \\
\hline$\$$ & 1 & 2 & \\
\hline$\$$ & 1 & 2 & \\
\hline$\$$ & 1 & 2 & \\
\hline$\$$ & 1 & 2 & \\
\hline
\end{tabular}




\section{B. Observation guide}

\section{INSTRUCTIONSTO DATA}

COLLECTOR: Before proceeding to observe the interaction between client and provider, use the greeting below to explain to the provider that you will be observing him/her while he attends to his/her clients to make sure that she/he knows that you are not there to evaluate her/him and that you are not an "expert" who can be consulted during the session. Then obtain the client's informed consent. When observing, be as discreet as possible: try to sit so that you are behind the client but not directly in view of the provider, and make notes quickly. For each question, describe or circle the code of the response that most appropriately represents your observation of what happened during the interaction. As discussed during the training, you may witness behavior that poses a serious risk to the client's health. Please keep in mind the guidelines for when to intervene in the consultation on behalf of the client's welfare.

\section{GREETING FOR THE PROVIDER: My} name is and I work with , where we are conducting a study

to see what information clients are given during postabortion care. This information will help us to propose ways in which to improve the services offered. As a part of this study, we are observing the interaction of health providers and their clients during their postabortion care visits. I will observe silently as you attend to your clients and take notes. I am in no way an expert in your area, and I am not here to evaluate your work. I will not make any comments or interfere in your consultations in any way.

Your participation in this component of the study will remain confidential. I will not record your name in the notes I take. This way, no one will be able to know that I observed your appointments. Do I have your permission?
INFORMED CONSENT FORM FOR THE CLIENT: My name is , and I work with , where we are conducting a study to see what information clients are given during their postabortion care visits. This information will help us to propose ways in which to improve the services offered. As a part of this study, we are observing the interaction of health providers and their clients during the treatment and counseling for postabortion care visits. I would appreciate it if you allowed me to observe your treatment and counseling today. If you do, I will be accompanying you through your visit and seeing what you and your provider talk about. I will also observe when he examines you. I am not a health provider in this facility and will not making any comments or participate in your consultations in any way. At the end of your visit I will, if you allow me to, ask you some questions regarding your experience during your visit. This interview will be private, and none of the providers that see you today will be present.

However, your participation in this study is voluntary, and you can choose not to let me accompany you or not to answer my questions. If you choose not to participate in either component of the study, you will not be penalized in any way. If you agree to participate and you change your opinion later, you can also ask me to exit the room whenever you want. If you participate, you will not receive money or gifts, and you will not benefit directly from your participation. However, your participation will result in improved future maternal and reproductive health services.

Your participation in this study will remain confidential. I will not record your name in the notes I take. This way, no one will be able to know that I observed your appointments.

Finally, if you have any questions about this study at a later stage, you can come back here and clear your doubts with your provider at the clinic. Do you accept to participate in this study? 


\section{Facility identification}

\begin{tabular}{|c|c|c|c|}
\hline No. & QUESTIONS & \multicolumn{2}{|l|}{ CODING CATEGORIES } \\
\hline 1.1 & Date of observations & (Day/Month/ Year) & \\
\hline 1.2 & Facility name & & \\
\hline 1.3 & City or locality & & \\
\hline \multirow[t]{7}{*}{1.4} & \multirow[t]{7}{*}{ Type of facility } & Hospital & 1 \\
\hline & & Health center with maternity ward & 2 \\
\hline & & Health center without maternity ward & 3 \\
\hline & & Health post with maternity ward & 4 \\
\hline & & Health post without maternity ward & 5 \\
\hline & & Dispensary & 6 \\
\hline & & Other: & 7 \\
\hline \multirow[t]{4}{*}{1.5} & \multirow[t]{4}{*}{ Type of sector } & Government & 1 \\
\hline & & NGO & 2 \\
\hline & & Private & 3 \\
\hline & & Other: & 4 \\
\hline \multirow[t]{4}{*}{1.6} & \multirow[t]{4}{*}{ Result of the observation } & Complete & 1 \\
\hline & & Incomplete & 2 \\
\hline & & Refused & 3 \\
\hline & & Other: & 4 \\
\hline
\end{tabular}

\section{FP services in PAC}

\section{No. QUESTIONS}

CODING CATEGORIES GO TO

Interviewer: Observe the client-provider interaction during

$P A C$ and note whether providers do the following.

2.1 Discuss return to fertility.

2.2 Ask whether client wants more children in the future.

2.3 Ask about FP use at the time of pregnancy.

2.4 Interviewer: Mark whether client was using an FP method.

2.5 Ask whether client may want to use a method.

2.6 Ask for any FP method preferences.

2.7 Explain different FP method options.

\begin{tabular}{ll|l}
2.8 & Interviewer: Mark the FP methods discussed. Combined oral contraceptives
\end{tabular}

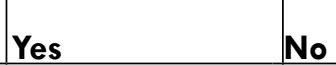

\section{No} Minipills (progestin-only pills)

Emergency contraceptive pills

Progestin-only injectables (injection

every 2 or 3 months)

Monthly injectables

Combined patches

Combined vaginal rings

Jadelle implants

Implanon implants

Sinoplant (II) implants

IUD

IUS

Male condoms

Female condoms

Diaphragms

Spermicides

Cervical caps

Female sterilization

Vasectomy

Fertility awareness methods

Withdrawal

Other:

\begin{tabular}{|l|l|c|c|c|}
\hline & \multicolumn{1}{|c|}{ Yes } & No & \\
\hline 2.9 & Explain who should use each method. & 1 & 2 & \\
\hline 2.10 & Explain how methods work and how they are used. & 1 & 2 & \\
\hline
\end{tabular}


2.11 Explain advantages of methods.

2.12 Explain disadvantages of methods.

2.13 Explain reversibility of methods.

2.14 Explain possible side-effects of methods.

2.15 Discuss client's fears and concerns about methods.

2.16 Mention that condom is the only FP method that protects against HIV/AIDS.

2.17 Explain where methods can be obtained.

2.18 Interviewer: Did the woman express interest in using an FP method?

2.19 Interviewer: What method did the client express an interest in?

Interviewer: Did the client receive her preferred method?

\begin{tabular}{|c|c|}
\hline Combined oral contraceptives & 1 \\
\hline Minipills (progestin-only pills) & 2 \\
\hline Emergency contraceptive pills & 3 \\
\hline $\begin{array}{l}\text { Progestin-only injectables (injection } \\
\text { every } 2 \text { or } 3 \text { months) }\end{array}$ & 4 \\
\hline Monthly injectables & 5 \\
\hline Combined patches & 6 \\
\hline Combined vaginal rings & 7 \\
\hline \begin{tabular}{|l|} 
Jadelle implants \\
\end{tabular} & 8 \\
\hline Implanon implants & 9 \\
\hline Sinoplant (II) implants & 10 \\
\hline IUD & 11 \\
\hline IUS & 12 \\
\hline Male condoms & 13 \\
\hline Female condoms & 14 \\
\hline Diaphragms & 15 \\
\hline Spermicides & 16 \\
\hline Cervical caps & 17 \\
\hline Female sterilization & 18 \\
\hline Vasectomy & 19 \\
\hline Fertility awareness methods & 20 \\
\hline Withdrawal & 21 \\
\hline Other: & 22 \\
\hline Yes & 1 \\
\hline No & 2 \\
\hline Method not available & 1 \\
\hline No specialist to assist with method & 2 \\
\hline Other: & 3 \\
\hline Yes & 1 \\
\hline No & 2 \\
\hline
\end{tabular}

Interviewer: Was the client referred to FP

services or to a place where she can obtain a method after today?

\begin{tabular}{|l|l|l}
\hline & 1 & \\
\hline & 1 & \\
\hline & 1 & \\
\hline 1 & \\
\hline
\end{tabular}

\begin{tabular}{|l|l|}
\hline 2 & \\
\hline 2 & \\
\hline 2 & \\
\hline 2 & \\
\hline 2 & \\
\hline
\end{tabular}

2.21 Interviewer: Why did the client not receive her preferred method?

\section{Introduction and clinical history}

\begin{tabular}{|c|c|c|c|}
\hline No. & QUESTIONS & CODING & ORIES \\
\hline Introd & uction & Yes & No \\
\hline 3.1 & Greet client. & 1 & 2 \\
\hline 3.2 & Introduce yourself to the client. & 1 & 2 \\
\hline 3.3 & $\begin{array}{l}\text { Tell the client what is going to be done and encourage her to } \\
\text { ask questions. }\end{array}$ & 1 & 2 \\
\hline Clinic & al history & Yes & No \\
\hline 3.4 & Review client's clinical record or pregnancy carnet. & 1 & 2 \\
\hline 3.5 & Ask date of last menstrual period. & 1 & 2 \\
\hline 3.6 & Ask history of hypertension. & 1 & 2 \\
\hline 3.7 & Ask history of diabetes. & 1 & 2 \\
\hline 3.8 & Ask about history of problems with current pregnancy. & 1 & 2 \\
\hline 3.9 & Ask about obstetric history. & 1 & 2 \\
\hline 3.10 & Ask about past medical history. & 1 & 2 \\
\hline 3.11 & Ask about surgical history. & 1 & 2 \\
\hline Recen & t birth history & Yes & No \\
\hline 3.12 & Ask number of prior pregnancies and births. & 1 & 2 \\
\hline 3.13 & Ask mode of delivery. & 1 & 2 \\
\hline 3.14 & $\begin{array}{l}\text { Ask whether client had heavy bleeding during or after delivery } \\
\text { with a previous pregnancy. }\end{array}$ & 1 & 2 \\
\hline
\end{tabular}


4. Physical exam

\begin{tabular}{|c|c|c|c|}
\hline No. & QUESTIONS & CODING CATEGOR & \\
\hline 4.1 & Wash hands before examining client. & Yes & No \\
\hline & & a) With water only & 2 \\
\hline & & b) Water and soap & \\
\hline & & c) With antiseptic & \\
\hline & & d) Other: & \\
\hline 4.2 & Take blood pressure. & 1 & 2 \\
\hline 4.3 & Take pulse. & 1 & 2 \\
\hline 4.4 & Take temperature. & 1 & 2 \\
\hline 4.5 & Auscultate heart. & 1 & 2 \\
\hline 4.6 & Examine abdomen. & 1 & 2 \\
\hline
\end{tabular}

5. Pain relief

\begin{tabular}{|l|l|l|l|}
\hline No. & QUESTIONS & CODING CATEGORIES \\
\hline 5.1 & $\begin{array}{l}\text { Did the woman ask for pain relief or show signs of } \\
\text { pain or distress at any time during her stay? }\end{array}$ & Yes, asked for pain relief & 1 \\
\cline { 3 - 4 } & & Yes, showed signs of pain & 2 \\
\hline 5.2 & Did the provider respond? & No & 3 \\
\hline \multirow{2}{*}{5.3} & \multirow{2}{*}{ How did they provider respond? } & No & 1 \\
\cline { 3 - 4 } & & Gave medication & 2 \\
\cline { 3 - 4 } & & Reassured client & 2 \\
\cline { 3 - 4 } & Scolded client & 3 \\
\cline { 3 - 4 } & & & 4 \\
\hline
\end{tabular}

\section{Information on danger signs}

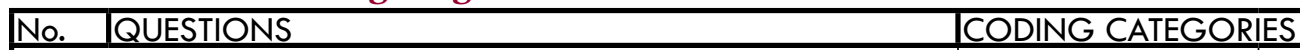

Interviewer: Before leaving the facility, was the woman instructed

about the following danger signs and symptoms that may arise?

$6.1 \quad$ Increased bleeding

6.2 Bleeding heavier than a normal period

6.3 Continued bleeding for 2 weeks

6.4 Foul-smelling vaginal discharge

6.5 Severe abdominal pain

6.6 Fever

6.7 Chills

6.8 Muscle aches

6.9 Tenderness to pressure in the abdomen

6.10 Delay (6 weeks or more) in resuming menstrual period

6.11 Dizziness or fainting

6.12 Feeling ill, weakness

6.13 Nausea or vomiting

6.14 Severe and constant headaches

6.15 Was the client told were to go in case she had any of these alarm signs?

\begin{tabular}{|l|l|}
\hline Yes & No \\
\hline 1 & 2 \\
\hline 1 & 2 \\
\hline 1 & 2 \\
1 & 2 \\
1 & 2 \\
\hline 1 & 2 \\
\hline 1 & 2 \\
\hline 1 & 2 \\
\hline 1 & 2 \\
\hline 1 & 2 \\
\hline 1 & 2 \\
\hline 1 & 2 \\
\hline 1 & 2 \\
\hline 1 & 2 \\
\hline 1 & 2 \\
\hline
\end{tabular}

\section{Information on follow-up care}

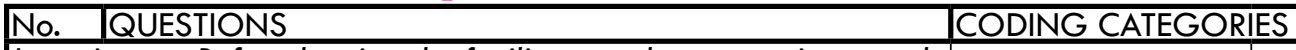

Interviewer: Before leaving the facility, was the woman instructed about the following?

7.1 When and where to return for a check-up

7.2 $\quad$ When she can start having sexual relations again

$\begin{array}{ll}7.3 & \text { Rest and hygiene precautions she needs to follow after }\end{array}$ leaving the facility

\section{Yes}

\begin{tabular}{l|l} 
& No \\
\hline 1 & \\
1 & \\
1 & \\
\hline
\end{tabular}

No

\begin{tabular}{l|}
\hline 2 \\
2 \\
2
\end{tabular}




\section{Client exit interview}

\section{INSTRUCTIONS FOR THE}

INTERVIEWER: Approach all women as they leave the area where PAC services are provided and asked them whether they are willing to be asked a few questions about the services they received today. If they accept, make sure that you are in a place that guarantees privacy and where the woman is comfortable. Ask them for their informed consent to be interviewed (read the form below). Interview only women who give their informed consent. For each item in the interview, circle the code of the adequate response or describe, as appropriate.

\section{INFORMED CONSENT FORM FOR THE} CLIENT: My name is , and I work with , where we are conducting a study to see what information clients are given when they are treated for postabortion care services. This information will help us to propose ways in which to improve the services offered. As a part of this study, we are interviewing women who had postabortion care services today. In these interviews, we ask them about the services and information they obtained, their satisfaction with the services received, their plans for having more children in the future, and other health needs they may have. I would appreciate it if you allowed me to ask you some questions. The interview will be private, and none of the providers that saw you today will be present.

However, your participation in this study is voluntary, and you can choose not to let me interview you. If you choose not to participate in our study, you will not be penalized in any way. If you accept to participate and you change your opinion later, you can also ask me to interrupt the interview whenever you want.

If you participate, you will not receive money or gifts, and you will not benefit directly from your participation. However, your participation will result in improved future maternal and reproductive health services.

Your participation in this study will remain confidential. I will not record your name in the questionnaire. This way, no one will be able to know that I observed your appointments.

Finally, if you have any questions about this study at a later stage, you can come back here and clear your doubts with your provider at the clinic. Do you accept to participate in this study?

\section{Facility identitfication}

\begin{tabular}{|c|c|c|c|}
\hline No. & QUESTIONS & \multicolumn{2}{|l|}{ CODING CATEGORIES } \\
\hline 1.1 & Date of interview & \multicolumn{2}{|l|}{ 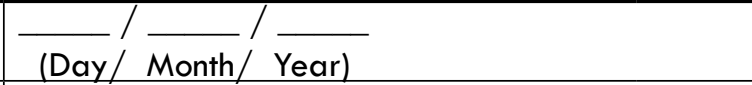 } \\
\hline 1.2 & Facility name & & \\
\hline 1.3 & City or locality & & \\
\hline \multirow{7}{*}{1.4} & Type of facility & Hospital & 1 \\
\hline & & Health center with maternity ward & 2 \\
\hline & & Health center without maternity ward & 3 \\
\hline & & Health post with maternity ward & 4 \\
\hline & & Health post without maternity ward & 5 \\
\hline & & Dispensary & 6 \\
\hline & & Other: & 7 \\
\hline \multirow[t]{4}{*}{1.5} & Type of sector & Government & 1 \\
\hline & & $\mathrm{NGO}$ & 2 \\
\hline & & Private & 3 \\
\hline & & Other: & 4 \\
\hline \multirow[t]{4}{*}{1.6} & \multirow[t]{4}{*}{ Result of the interview } & Complete & 1 \\
\hline & & Incomplete & 2 \\
\hline & & Refused & 3 \\
\hline & & Other: & 4 \\
\hline
\end{tabular}


2. Reproductive history

\begin{tabular}{|c|c|c|c|c|}
\hline No. & QUESTIONS & CODING CATEGORIES & & GO TO \\
\hline 2.1 & $\begin{array}{l}\text { How many living children of your own do } \\
\text { you have? }\end{array}$ & Living children: & & \\
\hline \multirow[t]{4}{*}{2.2} & \multirow{4}{*}{$\begin{array}{l}\text { In the future, would you like to have more } \\
\text { children? }\end{array}$} & Yes & 1 & \\
\hline & & No & 2 & $\begin{array}{l}\text { next } \\
\text { section }\end{array}$ \\
\hline & & Other: & 3 & \\
\hline & & Don't know & 98 & \\
\hline \multirow[t]{3}{*}{2.3} & \multirow{3}{*}{$\begin{array}{l}\text { How long would you like to wait before } \\
\text { becoming pregnant again? }\end{array}$} & Number of months: & & \\
\hline & & Number of years: & & \\
\hline & & Other: & & \\
\hline
\end{tabular}

\section{FP services during PAC}

\begin{tabular}{|c|c|c|c|c|}
\hline \multirow{3}{*}{$\frac{\text { No. }}{3.1}$} & QUESTIONS & CODING CATEGORIES & & GO TO \\
\hline & \multirow{2}{*}{$\begin{array}{l}\text { During this visit, did a health provider talk to } \\
\text { you about how soon you can get pregnant } \\
\text { again? }\end{array}$} & Yes & 1 & \\
\hline & & No & 2 & 3.3 \\
\hline \multirow[t]{7}{*}{3.2} & \multirow{5}{*}{$\begin{array}{l}\text { According to what they told you, how soon } \\
\text { is the earliest that a woman is fertile (can } \\
\text { become pregnant again) after she has had } \\
\text { an abortion? }\end{array}$} & Almost immediately & 1 & \\
\hline & & Before her period & 2 & \\
\hline & & After her period & 3 & \\
\hline & & Within 4 weeks & 4 & \\
\hline & & Within 4 weeks & 5 & \\
\hline & \multirow[t]{2}{*}{ Interviewer: Mark all that apply. } & Other: & 6 & \\
\hline & & Don't know & 98 & \\
\hline \multirow[t]{2}{*}{3.3} & \multirow{2}{*}{$\begin{array}{l}\text { During this visit, did a provider ask you } \\
\text { whether you wanted to get pregnant any } \\
\text { time soon? }\end{array}$} & Yes & 1 & \\
\hline & & No & 2 & \\
\hline \multirow[t]{2}{*}{3.4} & \multirow{2}{*}{$\begin{array}{l}\text { During this visit, did you receive any } \\
\text { information about FP methods? }\end{array}$} & Yes & 1 & \\
\hline & & No & 2 & 3.7 \\
\hline \multirow[t]{5}{*}{3.5} & \multirow[t]{5}{*}{ How did you get this information? } & Video & 1 & \\
\hline & & Individual talk & 2 & \\
\hline & & Group talk & 3 & \\
\hline & & Written material & 4 & \\
\hline & & Other: & 5 & \\
\hline \multirow[t]{23}{*}{3.6} & \multirow{3}{*}{$\begin{array}{l}\text { Which methods were discussed in the } \\
\text { information you received? }\end{array}$} & Combined oral contraceptives & 1 & \\
\hline & & Minipills (progestin-only pills) & 2 & \\
\hline & & Emergency contraceptive pills & 3 & \\
\hline & \multirow[t]{20}{*}{ Interviewer: Mark all that apply. } & $\begin{array}{l}\text { Progestin-only injectables (injection } \\
\text { every } 2 \text { or } 3 \text { months) }\end{array}$ & 4 & \\
\hline & & Monthly injectables & 5 & \\
\hline & & Combined patches & 6 & \\
\hline & & Combined vaginal rings & 7 & \\
\hline & & Jadelle implants & 8 & \\
\hline & & Implanon implants & 9 & \\
\hline & & Sinoplant (II) implants & 10 & \\
\hline & & IUD & 11 & \\
\hline & & IUS & 12 & \\
\hline & & Male condoms & 13 & \\
\hline & & Female condoms & 14 & \\
\hline & & Diaphragms & 15 & \\
\hline & & Spermicides & 16 & \\
\hline & & Cervical caps & 17 & \\
\hline & & Female sterilization & 18 & \\
\hline & & Vasectomy & 19 & \\
\hline & & Fertility awareness methods & 20 & \\
\hline & & Withdrawal & 21 & \\
\hline & & Other: & 22 & \\
\hline & & Don't know & 98 & \\
\hline
\end{tabular}




\begin{tabular}{|c|c|c|c|c|}
\hline \multirow[t]{2}{*}{3.7} & \multirow{2}{*}{$\begin{array}{l}\text { During this visit, did a health provider offer } \\
\text { you a FP method? }\end{array}$} & Yes & 1 & \\
\hline & & No & 2 & \\
\hline \multirow[t]{2}{*}{3.8} & \multirow[t]{2}{*}{ Did you receive an FP method today? } & Yes & 1 & \\
\hline & & No & 2 & 3.12 \\
\hline \multirow[t]{22}{*}{3.9} & \multirow[t]{22}{*}{ Which FP method did you receive? } & Combined oral contraceptives & 1 & \\
\hline & & Minipills (progestin-only pills) & 2 & \\
\hline & & Emergency contraceptive pills & 3 & \\
\hline & & $\begin{array}{l}\text { Progestin-only injectables (injection } \\
\text { every } 2 \text { or } 3 \text { months) }\end{array}$ & 4 & \\
\hline & & Monthly injectables & 5 & \\
\hline & & Combined patches & 6 & \\
\hline & & Combined vaginal rings & 7 & \\
\hline & & Jadelle implants & 8 & \\
\hline & & Implanon implants & 9 & \\
\hline & & Sinoplant (II) implants & 10 & \\
\hline & & IUD & 11 & \\
\hline & & IUS & 12 & \\
\hline & & Male condoms & 13 & \\
\hline & & Female condoms & 14 & \\
\hline & & Diaphragms & 15 & \\
\hline & & Spermicides & 16 & \\
\hline & & Cervical caps & 17 & \\
\hline & & Female sterilization & 18 & \\
\hline & & Vasectomy & 19 & \\
\hline & & Fertility awareness methods & 20 & \\
\hline & & Withdrawal & 21 & \\
\hline & & Other: & 22 & \\
\hline \multirow[t]{2}{*}{3.10} & \multirow[t]{2}{*}{$\begin{array}{l}\text { Is(Are) this(these) the method(s) you wanted } \\
\text { to use? }\end{array}$} & Yes & 1 & $\begin{array}{l}\text { next } \\
\text { section }\end{array}$ \\
\hline & & No & 2 & \\
\hline \multirow[t]{5}{*}{3.11} & \multirow[t]{2}{*}{$\begin{array}{l}\text { Why did you not receive the method you } \\
\text { wanted to use? }\end{array}$} & Cost & 1 & $\begin{array}{l}\text { next } \\
\text { section }\end{array}$ \\
\hline & & Method was not available. & 2 & $\begin{array}{l}\text { next } \\
\text { section }\end{array}$ \\
\hline & \multirow{3}{*}{ Interviewer: Mark all that apply. } & There is no operating room or surgeon. & 3 & $\begin{array}{l}\text { next } \\
\text { section }\end{array}$ \\
\hline & & Providers said I had contraindications. & 4 & $\begin{array}{r}\text { next } \\
\text { section }\end{array}$ \\
\hline & & Other: & 5 & $\begin{array}{l}\text { next } \\
\text { section }\end{array}$ \\
\hline \multirow[t]{2}{*}{3.12} & \multirow{2}{*}{$\begin{array}{l}\text { Would have you liked to receive an FP } \\
\text { method before leaving this facility today? }\end{array}$} & Yes & 1 & \\
\hline & & No & 2 & 3.14 \\
\hline \multirow[t]{6}{*}{3.13} & \multirow{3}{*}{$\begin{array}{l}\text { Why did you not receive a contraceptive } \\
\text { method today? }\end{array}$} & Cost & 1 & \\
\hline & & She was not offered one. & 2 & \\
\hline & & $\begin{array}{l}\text { The method she wanted was not } \\
\text { available. }\end{array}$ & 3 & \\
\hline & \multirow{3}{*}{ Interviewer: Mark all that apply. } & There is no operating room or surgeon. & 4 & \\
\hline & & $\begin{array}{l}\text { Providers said she has } \\
\text { contraindications. }\end{array}$ & 5 & \\
\hline & & Other: & 6 & \\
\hline \multirow[t]{2}{*}{3.14} & \multirow{2}{*}{$\begin{array}{l}\text { During this visit, did a health provider tell you } \\
\text { where you can obtain an FP method? }\end{array}$} & Yes & 1 & \\
\hline & & No & 2 & $\begin{array}{l}\text { next } \\
\text { section }\end{array}$ \\
\hline 3.15 & $\begin{array}{l}\text { Where did they tell you could obtain a FP } \\
\text { method? }\end{array}$ & & & \\
\hline
\end{tabular}


4. Quality of service of provider-client interactions

No QUESTIONS

CODING CATEGORIES

Interviewer: Explain that you will now ask some questions about the quality of the care the client received at this facility.

\begin{tabular}{|c|c|c|c|}
\hline \multirow[t]{3}{*}{4.1} & \multirow{3}{*}{$\begin{array}{l}\text { Did the provider who treated you tell you his or her } \\
\text { name? }\end{array}$} & Yes & 1 \\
\hline & & No & 2 \\
\hline & & Don't remember & 98 \\
\hline \multirow[t]{3}{*}{4.2} & \multirow{3}{*}{$\begin{array}{l}\text { During your stay in this facility, did the staff call you by } \\
\text { your name? }\end{array}$} & Yes & 1 \\
\hline & & No & 2 \\
\hline & & Don't remember & 98 \\
\hline \multirow[t]{3}{*}{4.3} & \multirow{3}{*}{$\begin{array}{l}\text { Did the doctor explain to you what would happen during } \\
\text { your treatment? Did you understand the explanation? }\end{array}$} & Yes & 1 \\
\hline & & No & 2 \\
\hline & & Don't remember & 98 \\
\hline
\end{tabular}

5. Pain management

\begin{tabular}{|c|c|c|c|}
\hline No. & QUESTIONS & CODING CATEGORIES & \\
\hline \multirow[t]{3}{*}{5.1} & \multirow{3}{*}{$\begin{array}{l}\text { Did a health provider ask you whether you } \\
\text { were feeling pain while you were in the facility } \\
\text { today? }\end{array}$} & Yes & 1 \\
\hline & & No & 2 \\
\hline & & Don't remember & 98 \\
\hline \multirow[t]{3}{*}{5.2} & \multirow{3}{*}{$\begin{array}{l}\text { Were you given any medication to ease the } \\
\text { pain? }\end{array}$} & Yes & 1 \\
\hline & & No & 2 \\
\hline & & Don't remember & 98 \\
\hline
\end{tabular}

6. Counseling about self-care and danger signs

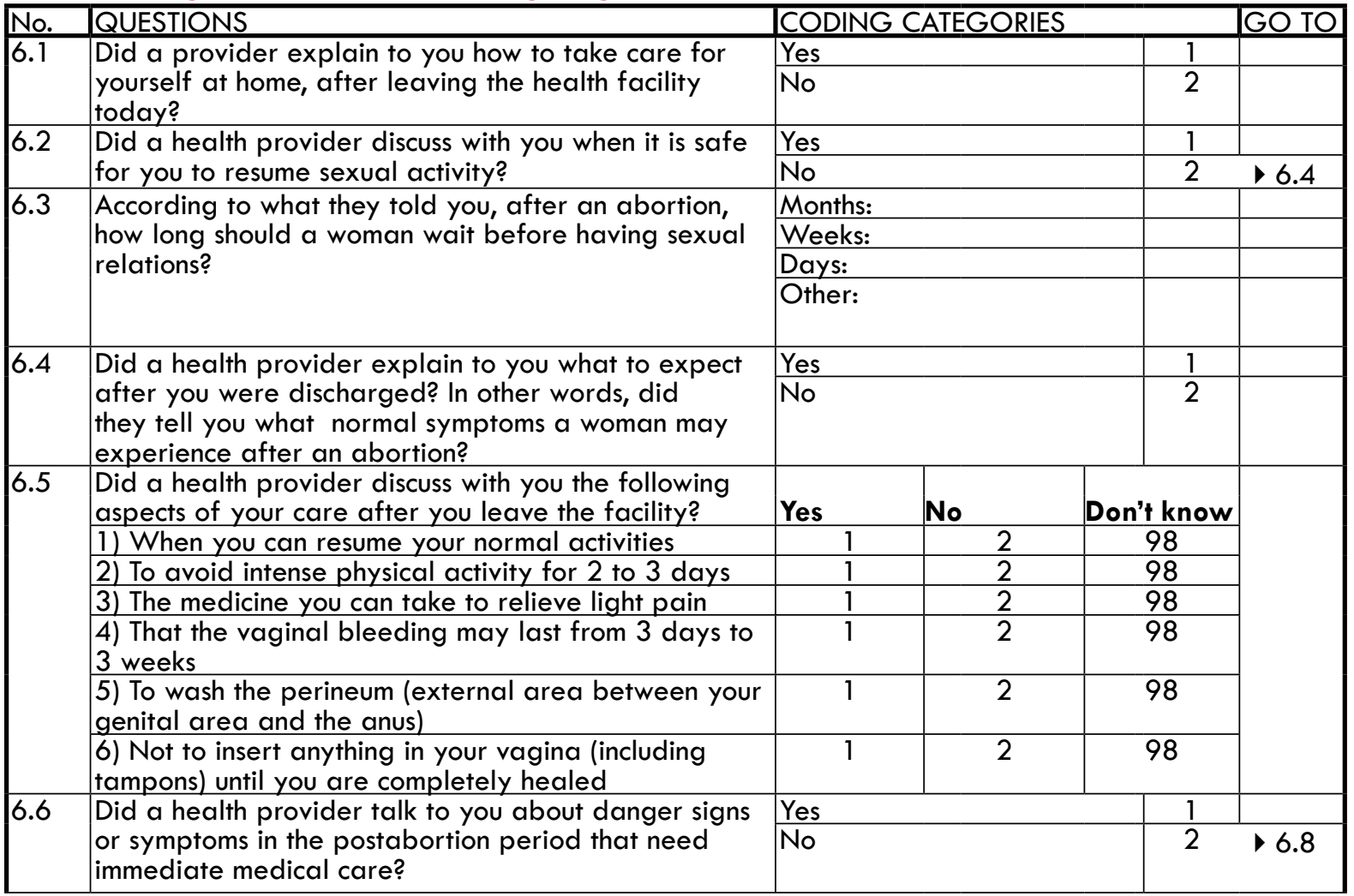




\begin{tabular}{|l|l|r|c|}
\hline 6.7 & \multicolumn{4}{|l|}{$\begin{array}{l}\text { What are the danger signs or symptoms for which they told you that you need immediate medical } \\
\text { care in the postabortion period? }\end{array}$} & \multicolumn{2}{l|}{ Don't know } \\
\hline $\begin{array}{l}\text { Interviewer: Record spontaneous responses, then ask } \\
\text { about remaining items. }\end{array}$ & Not aided & \multicolumn{1}{l|}{ Aided } & 98 \\
\hline Increased bleeding & 1 & 2 & 98 \\
\hline Bleeding heavier than a normal period & 1 & 2 & 98 \\
\hline Continued bleeding for 2 weeks & 1 & 2 & 98 \\
\hline Foul-smelling vaginal discharge & 1 & 2 & 98 \\
\hline Severe abdominal pain & 1 & 2 & 98 \\
\hline Fever & 1 & 2 & 98 \\
\hline Chills & 1 & 2 & 98 \\
\hline Muscle aches & 1 & 2 & 98 \\
\hline Tenderness to pressure in the abdomen & 1 & 2 & 98 \\
\hline Delay (6 weeks or more) in resuming menstrual period & 1 & 2 & 98 \\
\hline Dizziness or fainting & 1 & 2 & 98 \\
\hline Feeling ill, weakness & 1 & 2 & 98 \\
\hline Nausea or vomiting & 1 & 2 & 98 \\
\hline Severe and constant headache & 1 & 2 & 98 \\
\hline Other: & 1 & 2 & \\
\hline
\end{tabular}

7. Follow-up and information about other services and referrals

\begin{tabular}{|c|c|c|c|c|}
\hline No. & QUESTIONS & CODING CATEGORIES & & GO TO \\
\hline 7.1 & Did a health provider tell you when to make a & Yes & 1 & \\
\hline & follow-up visit? & No & 2 & 7.3 \\
\hline 7.2 & When were you told to come for a follow-up visit & In days: & & \\
\hline & (return date)? & In weeks: & & \\
\hline & & Other: & & \\
\hline 7.3 & During your stay in this facility, were you given & Yes & 1 & \\
\hline & information about other health services? & No & 2 & 7.5 \\
\hline 7.4 & About which services did you receive information? & FP & 1 & \\
\hline & & STIs & 2 & \\
\hline & & HIV/AIDS & 3 & \\
\hline & Interviewer: Mark all that apply. & Cervical cancer screening & 4 & \\
\hline & & Breast cancer screening & 5 & \\
\hline & & Counseling on how to deal with & 6 & \\
\hline & & $\begin{array}{l}\text { Violence trom my partner } \\
\text { Other. }\end{array}$ & 7 & \\
\hline & & & & \\
\hline 7.5 & During your visit today, were you referred for any & Yes & 1 & \\
\hline & services? & No & 2 & $\begin{array}{l}\text { next } \\
\text { section }\end{array}$ \\
\hline 7.6 & For what services were you referred? & FP & 1 & \\
\hline & & STIs detection and treatment & 2 & \\
\hline & & HIV/AIDS counseling and testing & 3 & \\
\hline & Interviewer: Mark all that apply. & Cervical cancer screening & 4 & \\
\hline & & $\begin{array}{l}\text { Counseling on how to deal with } \\
\text { violence from partner }\end{array}$ & 5 & \\
\hline & & Other: & 6 & \\
\hline
\end{tabular}

\section{IEC materials}

\begin{tabular}{|c|c|c|c|}
\hline No. & QUESTIONS & CODING CATEGORIES & \\
\hline \multirow[t]{2}{*}{8.1} & \multirow{2}{*}{$\begin{array}{l}\text { Did you receive any information materials during this } \\
\text { visit? }\end{array}$} & Yes & 1 \\
\hline & & No & 2 \\
\hline \multirow[t]{6}{*}{8.2} & \multirow{3}{*}{$\begin{array}{l}\text { What were they about? The content of the information } \\
\text { materials? }\end{array}$} & PAC & 1 \\
\hline & & FP & 2 \\
\hline & & STIs & 3 \\
\hline & \multirow{3}{*}{ Interviewer: Mark all that apply. } & HIV/AIDS & 4 \\
\hline & & Domestic violence & 5 \\
\hline & & Other: & 6 \\
\hline
\end{tabular}


9. Satisfaction with services

\begin{tabular}{|c|c|c|c|}
\hline No. & QUESTIONS & CODING CATEGORIES & \\
\hline \multirow[t]{4}{*}{9.1} & \multirow{4}{*}{$\begin{array}{l}\text { How long did you wait between the time you } \\
\text { arrived at this facility and the time you were } \\
\text { able to see a provider? }\end{array}$} & Minutes: & \\
\hline & & Hours: & \\
\hline & & Saw provider immediately & 97 \\
\hline & & Don't know & 98 \\
\hline \multirow[t]{4}{*}{9.2} & \multirow{4}{*}{$\begin{array}{l}\text { Would you strongly, not strongly, or never } \\
\text { recommend a friend to this facility? }\end{array}$} & Strongly recommend & 1 \\
\hline & & Recommend, but not strongly & 2 \\
\hline & & Never recommend & 3 \\
\hline & & Don't know & 98 \\
\hline \multirow[t]{7}{*}{9.3} & \multirow[t]{3}{*}{ Why? } & Courtesy & 1 \\
\hline & & Competence of staff & 2 \\
\hline & & Quality of services & 3 \\
\hline & \multirow[t]{4}{*}{ Interviewer: Mark all that apply. } & Overall environment & 4 \\
\hline & & Pace of services & 5 \\
\hline & & Cost & 6 \\
\hline & & Other: & 7 \\
\hline
\end{tabular}

\section{Costs}

\begin{tabular}{|c|c|c|c|}
\hline No. & QUESTIONS & CODING CATEGORIES & \\
\hline \multirow[t]{9}{*}{10.1} & \multirow{9}{*}{$\begin{array}{l}\text { How much did you pay for all services or } \\
\text { treatments you received at this facility today? } \\
\text { How much did you pay for travel? }\end{array}$} & Fees for client card: & \\
\hline & & Fees for procedure: & \\
\hline & & Fees for anesthesia: & \\
\hline & & Fees for laboratory tests: & \\
\hline & & Fees for medicines: & \\
\hline & & Other: & \\
\hline & & I did not pay anything at the clinic. & \\
\hline & & Travel: & \\
\hline & & Total: & \\
\hline \multirow[t]{4}{*}{10.2} & \multirow{4}{*}{$\begin{array}{l}\text { What do you think of the costs of your } \\
\text { treatment? }\end{array}$} & They were okay. & 1 \\
\hline & & Too much & 2 \\
\hline & & Other: & 3 \\
\hline & & Don't know & 98 \\
\hline
\end{tabular}

\section{Accessibility}

\begin{tabular}{|c|c|c|c|}
\hline$\longdiv { \text { No. } }$ & QUESTIONS & CODING CATEGORIES & \\
\hline \multirow[t]{7}{*}{11.1} & \multirow{3}{*}{$\begin{array}{l}\text { By what means of transport did you get to the } \\
\text { clinic today? }\end{array}$} & Taxi & 1 \\
\hline & & Bus & 2 \\
\hline & & Train & 3 \\
\hline & \multirow{4}{*}{ Interviewer: Mark all that apply. } & Private car & 4 \\
\hline & & Bicycle & 5 \\
\hline & & Walk & 6 \\
\hline & & Other: & 7 \\
\hline \multirow[t]{2}{*}{11.2} & \multirow{2}{*}{$\begin{array}{l}\text { Approximately how long did it take you to get } \\
\text { to the clinic today? }\end{array}$} & Hours: & \\
\hline & & Minutes: & \\
\hline \multirow[t]{2}{*}{11.3} & \multirow{2}{*}{$\begin{array}{l}\text { At approximately what time did you get to this } \\
\text { facility? }\end{array}$} & Hours: & \\
\hline & & Minutes: & \\
\hline \multirow[t]{2}{*}{11.4} & \multirow[t]{2}{*}{ Interviewer: Record current time. } & Hours: & \\
\hline & & Minutes: & \\
\hline \multirow[t]{2}{*}{11.5} & \multirow{2}{*}{$\begin{array}{l}\text { When you arrived to the health facility, did } \\
\text { you have any problem in receiving care? }\end{array}$} & Yes. Which one? & 1 \\
\hline & & No & 2 \\
\hline
\end{tabular}


12. Demographics

\begin{tabular}{|l|l}
\hline No. & QUESTIONS \\
\hline
\end{tabular}

12.1 How old are you?

12.2 What is your current marital status?

CODING CATEGORIES

Age in years:

Married, monogamous

Married, polygamous

Cohabiting/living with partner

Single, never married

Divorced/separated/widowed

\begin{tabular}{l|l|l}
12.3 & What is the highest level of school you attended? & Did not attend formal school
\end{tabular}

Primary

Secondary

Tertiary

Other:

1

2

3

4

5

1

2

3

4




\section{Provider interview}

\section{INSTRUCTIONS FOR THE}

INTERVIEWERS: Interview all health facility staff who are responsible for providing PAC, including FP services, to PAC clients. Please interview staff at the end of the working day or during their breaks. Make it clear that you are seeking their assistance in finding ways of improving the functioning and quality of the services offered by facilities in general and are not evaluating the performance of the facility or of them individually. For each item, circle the code of the adequate response or describe, as appropriate. Read the following greeting when you meet with each provider that you will interview.
GREETING: Good morning. My name is , and I work for

We are currently doing a study about the way that $\mathrm{FP}$ services are provided during postabortion care in the country and the problems that present obstacles to integration. As a part of this study, we are interviewing all health providers who participate in postabortion care, including FP services for postabortion women. These interviews are not to evaluate individual facilities or providers. We are visiting a number of facilities. All the information you give me will be confidential, and no one will know what you said. I will not record your name in the questionnaire, and there will be no way in which the responses you give me can be directly linked to you. They will all be confidential.

1. Facility identification

\begin{tabular}{|c|c|c|c|}
\hline No. & QUESTIONS & \multicolumn{2}{|l|}{ CODING CATEGORIES } \\
\hline 1.1 & Date of interview & \multicolumn{2}{|l|}{ (Day/ Month/ Year) } \\
\hline 1.2 & Facility name & & \\
\hline 1.3 & City or locality & & \\
\hline 1.4 & Type of facility & Hospital & 1 \\
\hline & & Health center with maternity ward & 2 \\
\hline & & Health center without maternity ward & 3 \\
\hline & & Health post with maternity ward & 4 \\
\hline & & Health post without maternity ward & 5 \\
\hline & & Dispensary & 6 \\
\hline & & Other: & 7 \\
\hline 1.5 & Type of sector & Government & 1 \\
\hline & & NGO & 2 \\
\hline & & Private & 3 \\
\hline & & Other: & 4 \\
\hline 1.6 & Result of the interview & Complete & 1 \\
\hline & & Incomplete & 2 \\
\hline & & Refused & 3 \\
\hline & & Other: & 4 \\
\hline
\end{tabular}


2. Demographics and professional experience

\begin{tabular}{|c|c|c|c|}
\hline \multirow{3}{*}{$\frac{\text { No. }}{2.1}$} & QUESTIONS & \multicolumn{2}{|l|}{ CODING CATEGORIES } \\
\hline & \multirow[t]{2}{*}{ Sex } & Male & 1 \\
\hline & & Female & 2 \\
\hline & \multicolumn{3}{|l|}{ Interviewer: Please mark. } \\
\hline 2.2 & How old are you? & Age in years: & \\
\hline \multirow[t]{9}{*}{2.3} & \multirow{9}{*}{ What is your current technical qualification? } & Specialist doctor & 1 \\
\hline & & General doctor & 2 \\
\hline & & Social service doctor & 3 \\
\hline & & Intern MD student & 4 \\
\hline & & Professional nurse & 5 \\
\hline & & Auxiliary nurse & 6 \\
\hline & & Nursing student & 7 \\
\hline & & Social worker & 8 \\
\hline & & Other: & 9 \\
\hline 2.4 & $\begin{array}{l}\text { How many years ago did you graduate with this } \\
\text { degree? }\end{array}$ & Years: & \\
\hline \multirow[t]{2}{*}{2.5} & \multirow[t]{2}{*}{ How long have you been working at this facility? } & Months: & \\
\hline & & Years: & \\
\hline \multirow[t]{3}{*}{2.6} & \multirow{3}{*}{$\begin{array}{l}\text { In which unit or department are you currently } \\
\text { working? }\end{array}$} & PAC & 1 \\
\hline & & FP & 2 \\
\hline & & Other: & 3 \\
\hline \multirow[t]{15}{*}{2.7} & \multirow{3}{*}{$\begin{array}{l}\text { What services do you directly provide at this } \\
\text { facility? }\end{array}$} & FP counseling & 1 \\
\hline & & Contraceptives & 2 \\
\hline & & Antenatal care & 3 \\
\hline & \multirow{12}{*}{ Interviewer: Mark all that apply. } & Delivery & 4 \\
\hline & & Postpartum care & 5 \\
\hline & & Treatment of abortion complications & 6 \\
\hline & & HIV/AIDS counseling & 7 \\
\hline & & HIV/AIDS testing & 8 \\
\hline & & HIV/AIDS treatment and care & 9 \\
\hline & & STI services & 10 \\
\hline & & Child immunization & 11 \\
\hline & & Child growth monitoring & 12 \\
\hline & & Curative services for women & 13 \\
\hline & & Curative services for children & 14 \\
\hline & & Other: & 15 \\
\hline
\end{tabular}

\section{Integration of PAC and FP}

\begin{tabular}{|c|c|c|c|c|c|c|}
\hline \multirow{9}{*}{\begin{tabular}{|l|} 
No. \\
3.1
\end{tabular}} & QUESTIONS & \multicolumn{4}{|c|}{ CODING CATEGORIES } & GO TO \\
\hline & \multirow{2}{*}{$\begin{array}{l}\text { Interviewer: (a) During your in-service } \\
\text { professional training, have you ever received } \\
\text { training in [read } 1 \text { to 6]? For every positive } \\
\text { response, ask: (b) Have you received training in } \\
\text { [...] in the past year? }\end{array}$} & \multicolumn{2}{|c|}{$\begin{array}{l}\text { (a) Ever received } \\
\text { training }\end{array}$} & \multicolumn{2}{|c|}{$\begin{array}{l}\text { (b) Received training } \\
\text { last year }\end{array}$} & \\
\hline & & Yes & No & Yes & No & \\
\hline & $\begin{array}{l}\text { 1) Counseling/health education for } \\
\text { postabortion clients }\end{array}$ & 1 & 2 & 1 & 2 & \\
\hline & 2) FP counseling techniques & 1 & 2 & 1 & 2 & \\
\hline & 3) FP counseling for postabortion clients & 1 & 2 & 1 & 2 & \\
\hline & $\begin{array}{l}\text { 4) Advantages and disadvantages of different } \\
\text { contraceptive methods }\end{array}$ & 1 & 2 & 1 & 2 & \\
\hline & $\begin{array}{l}\text { 5) Action mechanisms of different family } \\
\text { contraceptive methods }\end{array}$ & 1 & 2 & 1 & 2 & \\
\hline & 6) IUD insertions in postabortion women & 1 & 2 & 1 & 2 & \\
\hline \multirow[t]{5}{*}{3.2} & \multirow{3}{*}{$\begin{array}{l}\text { What are the main services, information, or } \\
\text { orientation you provide to PAC clients? }\end{array}$} & \multicolumn{3}{|c|}{ Comfort women } & 1 & \\
\hline & & \multirow{2}{*}{\multicolumn{3}{|c|}{\begin{tabular}{|l|} 
Advise on PAC and hygiene \\
Information about danger signs \\
\end{tabular}}} & 2 & \\
\hline & & & & & 3 & \\
\hline & \multirow{2}{*}{ Interviewer: Mark all the relevant options. } & \multicolumn{3}{|c|}{ FP counseling } & 4 & 3.4 \\
\hline & & \multicolumn{3}{|c|}{ Others: } & 5 & \\
\hline
\end{tabular}




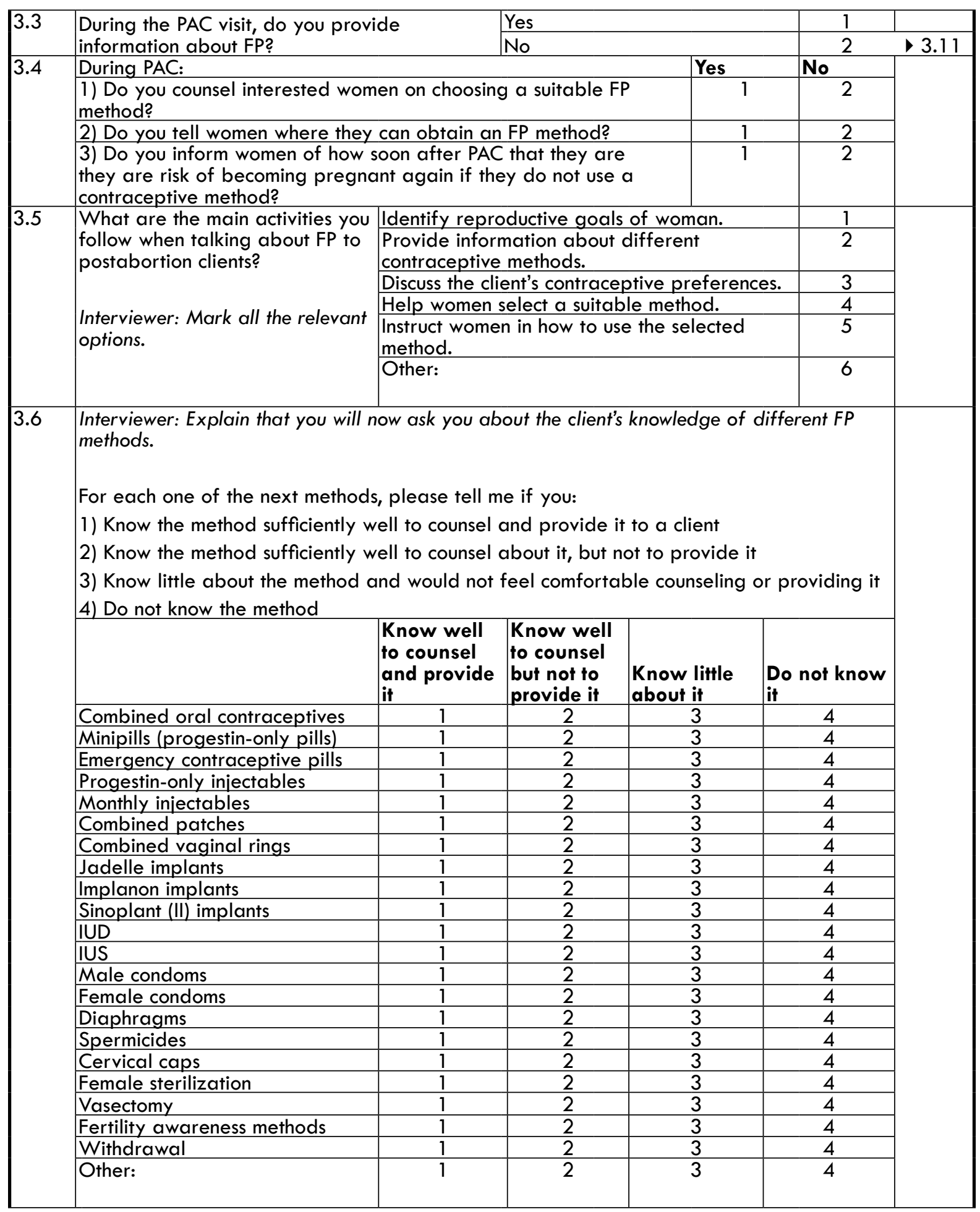




\begin{tabular}{|c|c|c|c|c|}
\hline \multirow[t]{10}{*}{3.7} & \multirow{10}{*}{$\begin{array}{l}\text { Do you know of any special } \\
\text { consideration to have in mind } \\
\text { while providing FP services to } \\
\text { postabortion women? Which } \\
\text { ones? } \\
\text { Interviewer: Mark all that apply. }\end{array}$} & No special considerations & 1 & \\
\hline & & $\begin{array}{l}\text { Infection should be ruled out or resolved } \\
\text { before the use of IUDs, female sterilization, } \\
\text { and fertility awareness methods. }\end{array}$ & 2 & \\
\hline & & $\begin{array}{l}\text { Injuries to the genital tract should be resolved } \\
\text { before the use of IUDs, combined vaginal } \\
\text { rings, spermicides, diaphragms, cervical caps, } \\
\text { female sterilization, and fertility awareness } \\
\text { methods. }\end{array}$ & 3 & \\
\hline & & $\begin{array}{l}\text { IUD insertion after a second-trimester } \\
\text { abortion requires a specifically trained } \\
\text { provider. }\end{array}$ & 4 & \\
\hline & & $\begin{array}{l}\text { Female sterilization must not be decided when } \\
\text { woman is sedated, under stress, or in pain. }\end{array}$ & 5 & \\
\hline & & $\begin{array}{l}\text { The diaphragm must be refitted after first- } \\
\text { trimester abortions. }\end{array}$ & 6 & \\
\hline & & $\begin{array}{l}\text { In second-trimester abortions, use of the } \\
\text { diaphragm must be delayed } 6 \text { weeks. }\end{array}$ & 7 & \\
\hline & & $\begin{array}{l}\text { Fertility-awareness methods should be started } \\
\text { once the woman has no infection-related } \\
\text { secretions or bleeding. }\end{array}$ & 8 & \\
\hline & & Other: & 9 & \\
\hline & & Don't know & 10 & \\
\hline \multirow[t]{4}{*}{3.8} & \multirow{3}{*}{$\begin{array}{l}\text { According to what you know, } \\
\text { how soon after PAC is a woman } \\
\text { at risk of getting pregnant } \\
\text { again? }\end{array}$} & Before 2 weeks if in a first-trimester abortion & 1 & \\
\hline & & $\begin{array}{l}\text { Within } 4 \text { weeks in a second- or third-trimester } \\
\text { abortion }\end{array}$ & 2 & \\
\hline & & Other: & 3 & \\
\hline & $\begin{array}{l}\text { Interviewer: Mark all the relevant } \\
\text { options. }\end{array}$ & Don't know & 98 & \\
\hline \multirow[t]{4}{*}{3.9} & \multirow{4}{*}{$\begin{array}{l}\text { From a medical point of } \\
\text { view, for how long should a } \\
\text { postabortion client wait before } \\
\text { becoming pregnant again? }\end{array}$} & \multicolumn{2}{|l|}{ Months: } & \\
\hline & & \multicolumn{2}{|l|}{ Weeks: } & \\
\hline & & \multicolumn{2}{|l|}{ Other: } & \\
\hline & & Don't know & 98 & \\
\hline \multirow[t]{8}{*}{3.10} & \multirow{8}{*}{$\begin{array}{l}\text { What are the main difficulties } \\
\text { you have had in this facility } \\
\text { in providing FP services for } \\
\text { postabortion clients in the last } 3 \\
\text { months? }\end{array}$} & Lack of supplies & 1 & \\
\hline & & Lack of qualified personnel & 2 & \\
\hline & & Lack of equipment & 3 & \\
\hline & & Failures in equipment & 4 & \\
\hline & & Inappropriate facilities & 5 & \\
\hline & & Do not feel sufficiently trained & 6 & \\
\hline & & Not enough time to counsel clients & 7 & \\
\hline & & Other: & 8 & \\
\hline \multirow[t]{3}{*}{3.11} & \multirow{3}{*}{$\begin{array}{l}\text { Are there any written guidelines } \\
\text { in this facility for providing FP } \\
\text { services to PAC clients? }\end{array}$} & Yes & 1 & \\
\hline & & No & 2 & 3.13 \\
\hline & & Don't know & 98 & 3.13 \\
\hline \multirow[t]{3}{*}{3.12} & \multirow{3}{*}{$\begin{array}{l}\text { How well do you know the } \\
\text { guidelines for providing FP } \\
\text { services to PAC clients? }\end{array}$} & Very well & 1 & \\
\hline & & Fairly well & 2 & \\
\hline & & Not well & 3 & \\
\hline 3.13 & $\begin{array}{l}\text { What are your suggestions for } \\
\text { improving the integration of FP } \\
\text { with postabortion services? }\end{array}$ & \multicolumn{2}{|l|}{ Recommendations: } & \\
\hline
\end{tabular}


4. PAC experience, knowledge, and practices

\begin{tabular}{|c|c|c|c|c|}
\hline No. & QQUESTIONS & CODING CATEGORIES & & GO TO \\
\hline 4.1 & Are you directly involved in the & Yes & 1 & \\
\hline & $\begin{array}{l}\text { clinical treatment of women with } \\
\text { postabortion complications? }\end{array}$ & No & 2 & 4.5 \\
\hline 4.2 & $\begin{array}{l}\text { For how many years in total have } \\
\text { you provided this service, including } \\
\text { your work in other facilities? }\end{array}$ & $\begin{array}{l}\text { Years: } \\
\text { Interviewer: If less than } 1 \text { year, record "00." }\end{array}$ & & \\
\hline 4.3 & Do you consider yourself competent & MVA & 1 & \\
\hline & to practice the following. & Electric vacuum aspiration & 2 & \\
\hline & & $\mathrm{D} \& \mathrm{C}$ & 3 & \\
\hline & $\begin{array}{l}\text { Interviewer: Read the options and } \\
\text { mark all the relevant ones. }\end{array}$ & & & \\
\hline 4.4 & Which of the following methods do & MVA & 1 & \\
\hline & you personally use to treat women & Digital curage & 2 & \\
\hline & with incomplete abortions and & $D \& C$ & 3 & \\
\hline & abortion complications? & Abortion with drugs & 4 & \\
\hline & 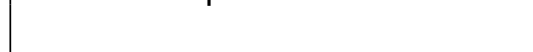 & Other: & 5 & \\
\hline & $\begin{array}{l}\text { Interviewer: Read the options and } \\
\text { mark all the relevant ones. }\end{array}$ & & & \\
\hline 4.5 & Do you currently provide & Yes & 1 & \\
\hline & $\begin{array}{l}\text { postabortion counseling or } \\
\text { orientation to women in this facility? }\end{array}$ & No & 2 & 4.10 \\
\hline 4.6 & $\begin{array}{l}\text { For how many years in total have } \\
\text { you provided this service? Please } \\
\text { include your work at other facilities. }\end{array}$ & $\begin{array}{l}\text { Years: } \\
\text { Interviewer: If less than } 1 \text { year, record "00." }\end{array}$ & & \\
\hline 4.7 & What are the main components of & Comfort woman & 1 & \\
\hline & the counseling and orientation you & Inform about health condition & 2 & \\
\hline & offer to postabortion clients? & Inform about surgical procedure & 3 & \\
\hline & & Inform about post-treatment care & 4 & \\
\hline & & Inform about danger signs & 5 & \\
\hline & Interviewer: Mark all that apply. & Counsel about FP & 6 & \\
\hline & & Counsel about STIs, HIV/AIDS & 7 & \\
\hline & & Respond to questions and concerns & 8 & \\
\hline & & Refer to other services & 9 & \\
\hline & & Other: & 10 & \\
\hline 4.8 & $\begin{array}{l}\text { What are the main } \\
\text { recommendations for personal care }\end{array}$ & $\begin{array}{l}\text { Avoid intense physical activity for } 2 \text { to } 3 \\
\text { days. }\end{array}$ & 1 & \\
\hline & that should be given to postabortion & The medicine they can take to relieve pain & 2 & \\
\hline & women? & To wash the perineum & 3 & \\
\hline & & To avoid vaginal sex until bleeding stops & 4 & \\
\hline & lentoriour Alack all rolount & (2) & 5 & \\
\hline & options. & & & \\
\hline & & Don't know & 98 & \\
\hline 4.9 & What are the danger signs in the & Increased bleeding & 1 & \\
\hline & postabortion period? & Bleeding heavier than abnormal period & 2 & \\
\hline & & Continued bleeding for 2 weeks & 3 & \\
\hline & & Foul-smelling vaginal discharge & 4 & \\
\hline & Interviewer: Mark all that apply. & Severe abdominal pain & 5 & \\
\hline & & Fever & 6 & \\
\hline & & Chills & 7 & \\
\hline & & Muscle aches & 8 & \\
\hline & & Tenderness to pressure in the abdomen & 9 & \\
\hline & & $\begin{array}{l}\text { Delay (6 weeks or more) in resuming } \\
\text { menstrual period }\end{array}$ & 10 & \\
\hline & & Dizziness or fainting & 11 & \\
\hline & & Feeling ill, weakness & 12 & \\
\hline & & Nausea or vomiting & 13 & \\
\hline & & Severe and constant headache & 14 & \\
\hline & & Other: & 15 & \\
\hline & & Don't know & 98 & \\
\hline
\end{tabular}




\begin{tabular}{|c|c|c|c|c|}
\hline \multirow[t]{9}{*}{4.10} & \multirow{9}{*}{$\begin{array}{l}\text { What are the main difficulties you } \\
\text { have had in this facility in treating } \\
\text { postabortion women in the last } 3 \\
\text { months? }\end{array}$} & Lack of supplies & 1 & \\
\hline & & Lack of qualified personnel & 2 & \\
\hline & & Lack of equipment & 3 & \\
\hline & & Failures in equipment & 4 & \\
\hline & & Inappropriate facilities & 5 & \\
\hline & & Do not feel adequately trained & 6 & \\
\hline & & Not enough time to treat clients & 7 & \\
\hline & & Other: & 8 & \\
\hline & & Don't know & 98 & \\
\hline \multirow[t]{3}{*}{4.11} & \multirow{3}{*}{$\begin{array}{l}\text { Does this health facility have } \\
\text { guidelines for PAC? }\end{array}$} & Yes & 1 & \\
\hline & & No & 2 & $\begin{array}{l}\text { next } \\
\text { section }\end{array}$ \\
\hline & & Don't know & 98 & $\begin{array}{l}\text { next } \\
\text { section }\end{array}$ \\
\hline \multirow[t]{3}{*}{4.12} & \multirow{3}{*}{$\begin{array}{l}\text { How well do you know the } \\
\text { guidelines for PAC? }\end{array}$} & Very well & 1 & \\
\hline & & Fairly well & 2 & \\
\hline & & Not well & 3 & \\
\hline
\end{tabular}

5. Suggestions for improving PAC

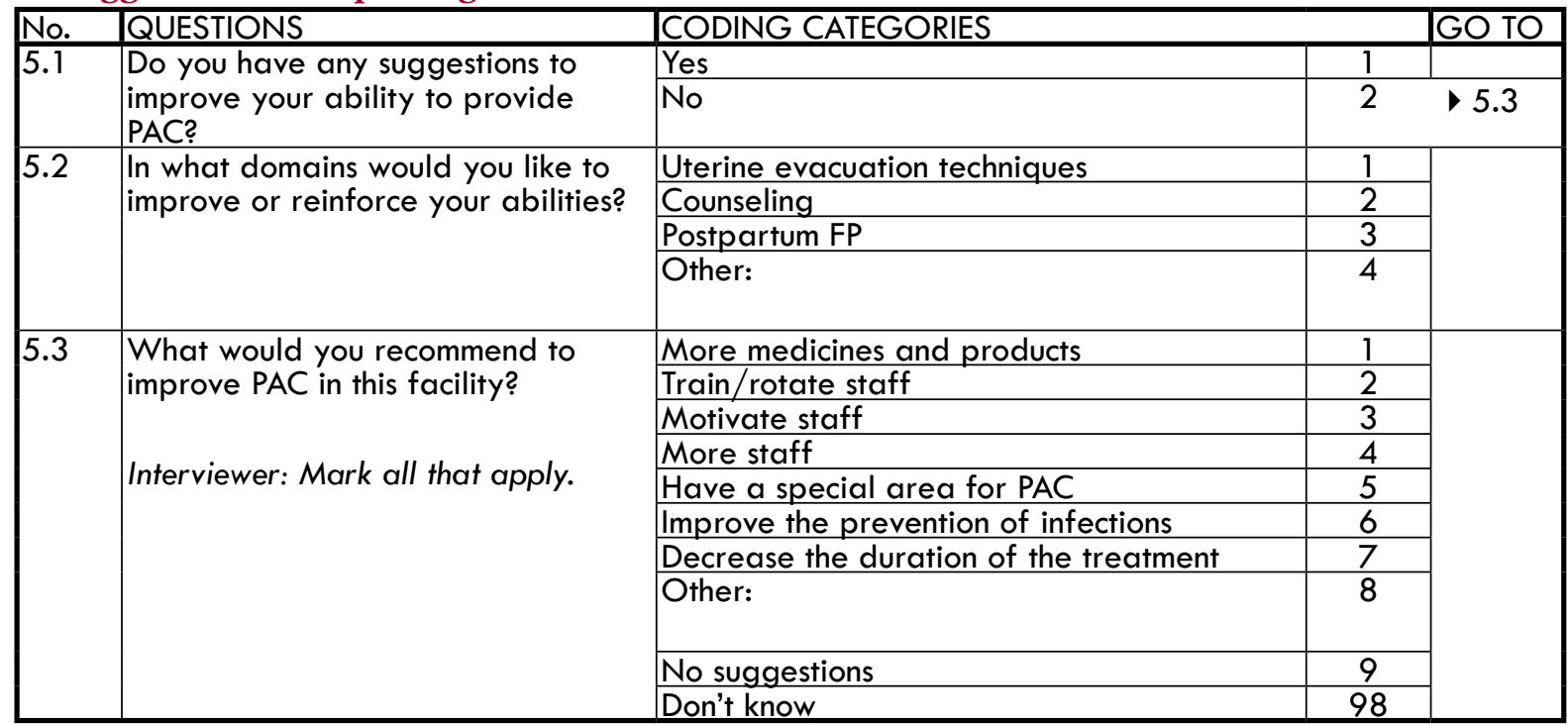

\section{Supervision}

\begin{tabular}{|c|c|c|c|c|c|c|}
\hline \multirow{3}{*}{$\frac{\text { No. }}{6.1}$} & \multirow{3}{*}{$\begin{array}{l}\text { QUESTIONS } \\
\text { In the last } 6 \text { months, has a supervisor } \\
\text { spoken with you about your work or } \\
\text { observed your work? }\end{array}$} & \multicolumn{4}{|c|}{ CODING CATEGORIES } & GO TO \\
\hline & & \multicolumn{3}{|c|}{ Yes } & 1 & \multirow[b]{2}{*}{ end } \\
\hline & & \multicolumn{3}{|l|}{ No } & 2 & \\
\hline 6.2 & $\begin{array}{l}\text { How many times in the last } 6 \text { months } \\
\text { has your work been supervised? }\end{array}$ & \multicolumn{3}{|l|}{ Number of times: } & & \\
\hline \multirow[t]{6}{*}{6.3} & \multicolumn{2}{|c|}{$\begin{array}{l}\text { Did your supervisor do the following the last time she/he } \\
\text { supervised you? }\end{array}$} & Yes & \multicolumn{2}{|l|}{ No } & \\
\hline & \multicolumn{2}{|l|}{ 1) Checked your records } & 1 & \multicolumn{2}{|l|}{2} & \\
\hline & \multicolumn{2}{|l|}{ 2) Observed your work } & 1 & \multicolumn{2}{|l|}{2} & \\
\hline & \multicolumn{2}{|c|}{ 3) Provided feedback on your performance } & 1 & \multicolumn{2}{|l|}{2} & \\
\hline & \multicolumn{2}{|c|}{$\begin{array}{l}\text { 4) Provided updates on administrative or technical issues } \\
\text { related to your work }\end{array}$} & 1 & \multicolumn{2}{|l|}{2} & \\
\hline & \multicolumn{2}{|c|}{ 5) Discussed problems you have encountered } & 1 & \multicolumn{2}{|l|}{2} & \\
\hline
\end{tabular}


This section contains the three basic instruments for conducting an AIM for using FP services as a platform for offering or integrating HIV and STI prevention and detection services. Instruments are presented in the following order:

\section{A) Inventory for facilities available and services provided at the facility \\ B) Observation guide \\ C) Questionnaire for clients' exit interview \\ D) Questionnaire for providers' interviews}

Since some may be interested in using AIM to gather information exclusively about how FP services can be used as an entry point for HIV and STI prevention and detection services, while others may want to take advantage of a research team already visiting the facility to obtain information about the general quality of these services, the instruments below contain questions that are relevant for both purposes. The first three modules of the inventories, the first two modules of the observation guide, and the first four modules of the interviews are designed to serve as a questionnaire that can easily be adapted to any study that focuses exclusively on measuring how FP services are integrated with HIV and STI prevention and detection services.

All the modules following the integration modules are designed to assess different components of the quality of FP and HIV and STI prevention and detection services. Those interested in this aspect can adapt the whole instruments to their own context. Some of the questions in these modules are relevant only in certain contexts or for specific objectives, such as those that refer to accessibility or the questions about costs. These optional questions are shaded for easy identification. We recommend that only those questions that are directly linked to the objectives of each study (as defined by the researchers) are included in the final questionnaires. Otherwise, research teams risk wasting money and time collecting too much information that will not be used.

\section{A. Inventory for facilities available and services provided at the facility}

\section{INSTRUCTIONS TO DATA}

COLLECTOR: This inventory should be completed by observing the facilities that are available and having discussions with the person in charge of FP services on the day of the visit

For some of the questions in this instrument, you will have to observe directly the availability of equipment, supplies, and infrastructure. Ask the clinic staff member who is assisting you to direct you to the room, laboratory, or storage area that you need to verify the availability of each item. In all cases, you should verify that the items exist by actually observing them yourself; if you are not able to observe them, then code accordingly. Remember that the objective of the inventory is to identify equipment and facilities that currently exist and are in working order and not to evaluate the performance of the staff or the clinic. For each item, circle the code of the adequate response or describe, as appropriate. For each item, circle the code of the most suitable response or describe as appropriate. Read the following greeting when you meet with the person who will help you complete the inventory.

GREETING: Good morning. My name is , and I work for

We are currently doing a study about the way that family planning services are being integrated with HIV and STI prevention and detection counseling and the issues that arise with integration. This is not an evaluation of this facility or of the staff who provide us this information. We are visiting a number of facilities. All the information will be combined, and all the information you provide me will be confidential. No one will know what you said. Are you willing to assist? 
1. Facility identification

\begin{tabular}{|c|c|c|c|}
\hline No. & QUESTIONS & \multicolumn{2}{|l|}{ CODING CATEGORIES } \\
\hline 1.1 & Date of observation & (Day/Month/ Year) & \\
\hline 1.2 & Facility name & & \\
\hline 1.3 & City or locality & & \\
\hline \multirow[t]{7}{*}{1.4} & \multirow[t]{7}{*}{ Type of facility } & Hospital & 1 \\
\hline & & Health center with maternity ward & 2 \\
\hline & & Health center without maternity ward & 3 \\
\hline & & Health post with maternity ward & 4 \\
\hline & & Health post without maternity ward & 5 \\
\hline & & Dispensary & 6 \\
\hline & & Other: & 7 \\
\hline \multirow[t]{4}{*}{1.5} & \multirow[t]{4}{*}{ Type of sector } & Government & 1 \\
\hline & & $\mathrm{NGO}$ & 2 \\
\hline & & Private & 3 \\
\hline & & Other: & 4 \\
\hline \multirow[t]{4}{*}{1.6} & \multirow[t]{4}{*}{ Result of the inventory } & Complete & 1 \\
\hline & & Incomplete & 2 \\
\hline & & Refused & 3 \\
\hline & & Other: & 4 \\
\hline
\end{tabular}

\section{Current integration between FP and HIV/STI prevention and detection services}

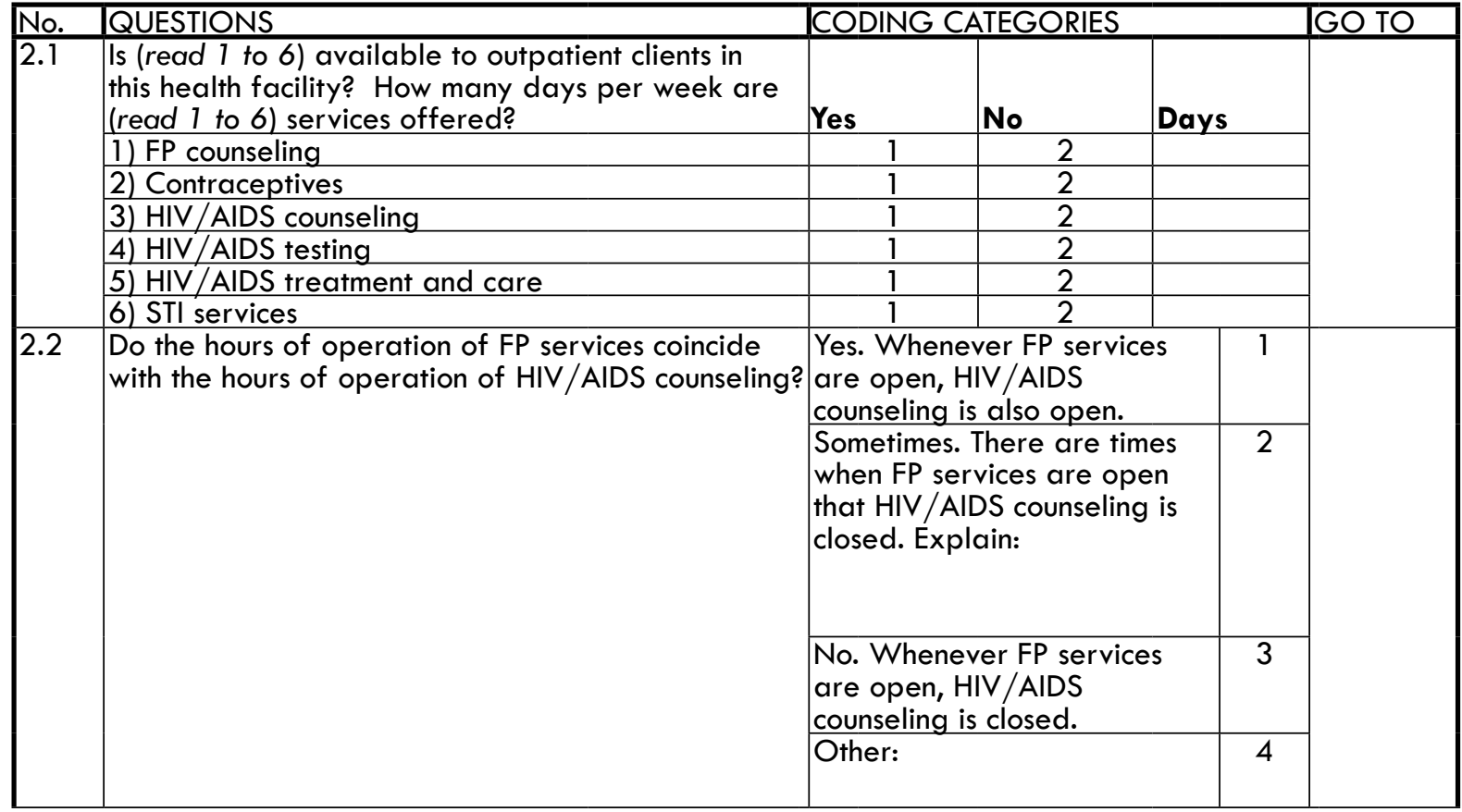




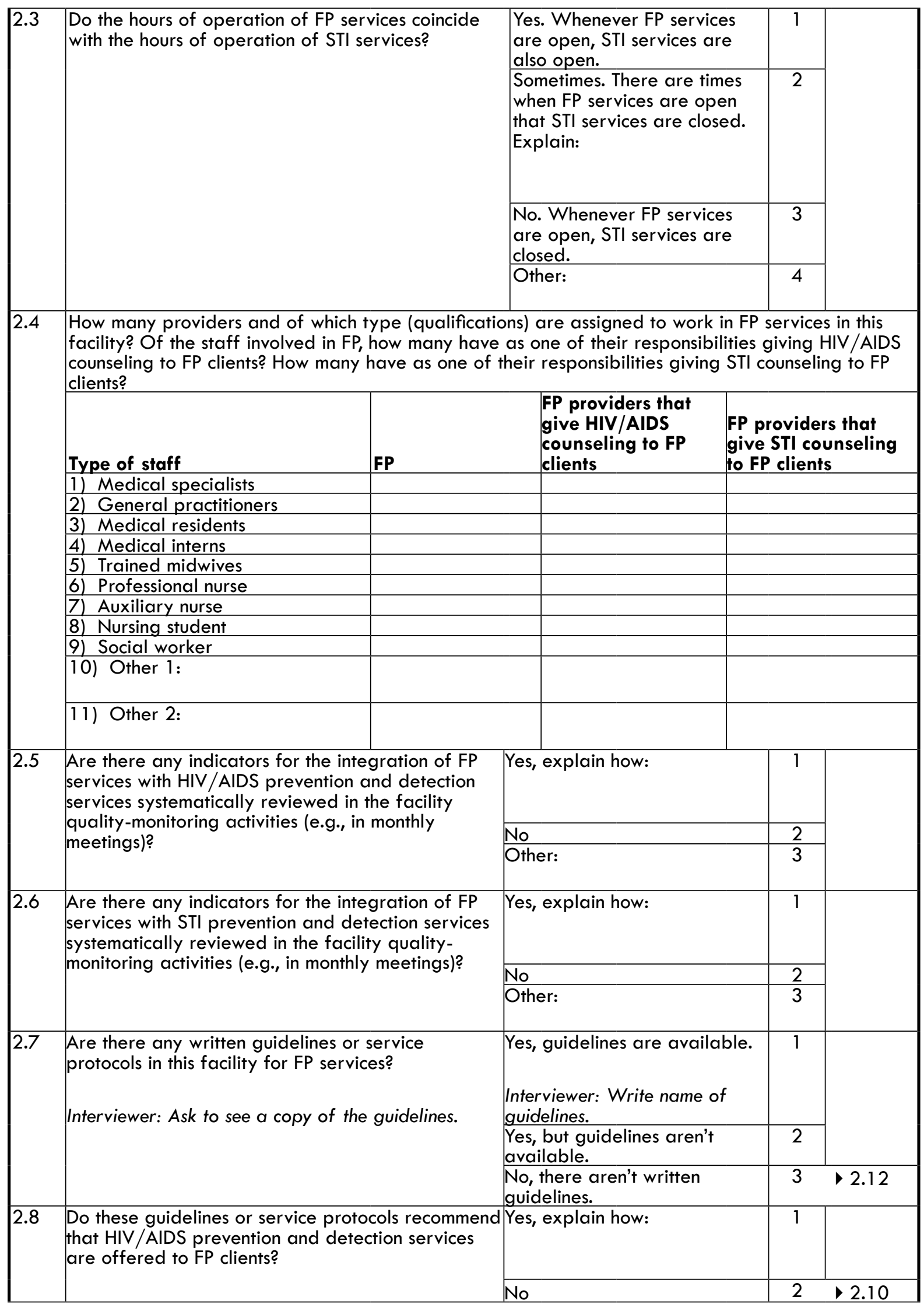




\begin{tabular}{|c|c|c|c|c|}
\hline 2.9 & $\begin{array}{l}\text { Which HIV/AIDS prevention and detection services } \\
\text { do the guidelines or protocols recommend for FP } \\
\text { clients? } \\
\text { Interviewer: Mark all that apply. }\end{array}$ & \begin{tabular}{|l|} 
Counseling \\
Testing \\
Other:
\end{tabular} & $\begin{array}{l}1 \\
2 \\
3\end{array}$ & \\
\hline 2.10 & $\begin{array}{l}\text { Do these guidelines or service protocols recommend } \\
\text { that STI prevention and detection services are } \\
\text { offered to FP clients? }\end{array}$ & $\begin{array}{l}\text { Yes, explain how: } \\
\text { No }\end{array}$ & $\frac{1}{2}$ & - 2.12 \\
\hline 2.11 & $\begin{array}{l}\text { Which STI prevention and detection services do the } \\
\text { guidelines or protocols recommend for FP clients? } \\
\text { Interviewer: Mark all that apply. }\end{array}$ & $\begin{array}{l}\text { Counseling on prevention } \\
\text { Testing } \\
\text { Syndromic management } \\
\text { Other: }\end{array}$ & $\begin{array}{l} \\
2 \\
3 \\
4\end{array}$ & \\
\hline 2.12 & $\begin{array}{l}\text { Are HIV/AIDS prevention and detection services } \\
\text { routinely offered to FP clients in this facility? }\end{array}$ & \begin{tabular}{|l|} 
Yes \\
No
\end{tabular} & $\frac{1}{2}$ & 2.17 \\
\hline 2.13 & $\begin{array}{l}\text { Which HIV/AIDS prevention and detection services } \\
\text { are routinely offered to FP clients in this facility? } \\
\text { Interviewer: Mark all that apply. }\end{array}$ & \begin{tabular}{|l|} 
Counseling \\
Testing \\
Other:
\end{tabular} & $\begin{array}{l}1 \\
2 \\
3\end{array}$ & \\
\hline 2.14 & $\begin{array}{l}\text { Who gives HIV/AIDS counseling to FP clients? The } \\
\text { same provider who gives them FP or someone else? }\end{array}$ & $\begin{array}{l}\text { Same provider } \\
\text { Someone else } \\
\text { Other: }\end{array}$ & $\begin{array}{l}1 \\
2 \\
3\end{array}$ & \\
\hline 2.15 & Where do FP clients receive HIV/AIDS counseling? & $\begin{array}{l}\text { In the same area where they } \\
\text { receive FP services } \\
\text { Somewhere else, where? }\end{array}$ & 2 & 2.17 \\
\hline 2.16 & $\begin{array}{l}\text { Why is HIV/AIDS counseling not provided in the } \\
\text { same area where women receive FP services? }\end{array}$ & $\begin{array}{l}\text { There is not staff available. } \\
\text { Staff is not trained. } \\
\text { The facility does not have the } \\
\text { necessary equipment. } \\
\text { There is insufficient room/ } \\
\text { space. } \\
\text { Other: }\end{array}$ & $\begin{array}{l}1 \\
2 \\
3\end{array}$ & \\
\hline 2.17 & $\begin{array}{l}\text { Are STI prevention and detection services routinely } \\
\text { offered to FP clients in this facility? }\end{array}$ & \begin{tabular}{|l|} 
Yes \\
No
\end{tabular} & $\frac{1}{2}$ & 2.22 \\
\hline 2.18 & $\begin{array}{l}\text { Which STI prevention and detection services are } \\
\text { routinely offered to FP clients in this facility? } \\
\text { Interviewer: Mark all that apply. }\end{array}$ & \begin{tabular}{|l|} 
Counseling \\
Testing \\
Other:
\end{tabular} & $\begin{array}{l}1 \\
2 \\
3\end{array}$ & \\
\hline 2.19 & $\begin{array}{l}\text { Who gives STI counseling to FP clients? The same } \\
\text { provider who gives them FP or someone else? }\end{array}$ & \begin{tabular}{|l|} 
Same provider \\
Someone else \\
Other:
\end{tabular} & $\begin{array}{l}1 \\
2 \\
3\end{array}$ & \\
\hline 2.20 & Where do FP clients receive STI counseling? & $\begin{array}{l}\text { In the same area where they } \\
\text { receive FP services } \\
\text { Somewhere else, where? }\end{array}$ & 1 & $\begin{array}{l}\text { next } \\
\text { section }\end{array}$ \\
\hline \multirow[t]{4}{*}{2.21} & \multirow[t]{4}{*}{$\begin{array}{l}\text { Why is STI counseling not provided in the same } \\
\text { area where women receive FP services? }\end{array}$} & There is not staff available. & 1 & $\begin{array}{l}\text { next } \\
\text { section }\end{array}$ \\
\hline & & Staff is not trained. & 2 & $\begin{array}{l}\text { next } \\
\text { section }\end{array}$ \\
\hline & & $\begin{array}{l}\text { The facility does not have the } \\
\text { necessary equipment. }\end{array}$ & 3 & $\begin{array}{l}\text { next } \\
\text { section }\end{array}$ \\
\hline & & Other: & 4 & $\begin{array}{l}\text { next } \\
\text { section }\end{array}$ \\
\hline 2.22 & Are FP clients routinely referred to other services? & \begin{tabular}{|l|} 
Yes \\
No
\end{tabular} & $\frac{1}{2}$ & $\begin{array}{l}\text { next } \\
\text { section }\end{array}$ \\
\hline
\end{tabular}




\begin{tabular}{|c|c|c|c|}
\hline 2.23 & To what location or room are FP client referred? & & \\
\hline 2.24 & $\begin{array}{l}\text { For what other additional services are FP clients } \\
\text { referred? }\end{array}$ & $\begin{array}{l}\text { HIV VCT } \\
\text { STI screening and } \\
\text { treatment } \\
\text { Pap smears } \\
\text { Breast cancer screening } \\
\text { Other: }\end{array}$ & $\begin{array}{l}3 \\
4 \\
5\end{array}$ \\
\hline 2.25 & $\begin{array}{l}\text { How are FP clients referred in the case of routine } \\
\text { referrals? }\end{array}$ & \begin{tabular}{|l|} 
Verbally \\
With a written referral \\
Other:
\end{tabular} & $\begin{array}{l}1 \\
2 \\
3\end{array}$ \\
\hline 2.26 & $\begin{array}{l}\text { How are FP clients referred in the case of other } \\
\text { referrals? }\end{array}$ & $\begin{array}{l}\text { Verbally } \\
\text { With a written referral } \\
\text { Other: }\end{array}$ & $\begin{array}{l}1 \\
2 \\
3\end{array}$ \\
\hline 2.27 & $\begin{array}{l}\text { Do you have a way of knowing whether the FP clients } \\
\text { went to the referral services? }\end{array}$ & Explain: & \\
\hline
\end{tabular}

3. Potential for further integration between FP and HIV/STI prevention and detection services

\begin{tabular}{|c|c|c|c|c|}
\hline \multirow{4}{*}{\begin{tabular}{|l} 
No. \\
3.1
\end{tabular}} & \multirow{4}{*}{$\begin{array}{l}\text { QUESTIONS } \\
\text { Is there an FP clinic at this health facility, or are } \\
\text { FP services mainly offered at outpatient service } \\
\text { consultations? }\end{array}$} & \multicolumn{2}{|l|}{ CODING CATEGORIES } & GO TO \\
\hline & & There is a clinic or special room. & 1 & \\
\hline & & They are mainly offered at & 2 & \\
\hline & & Other: & 3 & \\
\hline \multirow[t]{3}{*}{3.2} & How do FP clients come to the service? All at & All at once & 1 & \\
\hline & once or trickle in? & Trickle in & 2 & \\
\hline & & Other: & 3 & \\
\hline \multirow[t]{2}{*}{3.3} & Do FP clients wait for services together? & Yes & 1 & \\
\hline & & No & 2 & \\
\hline \multirow[t]{3}{*}{3.4} & $\begin{array}{l}\text { Is there a provider available to do a group } \\
\text { education session during the time that FP clients }\end{array}$ & $\begin{array}{l}\text { Yes, an education session is } \\
\text { already being done. }\end{array}$ & 1 & \\
\hline & are waiting? & Yes & 2 & \\
\hline & & No & 3 & \\
\hline \multirow[t]{4}{*}{3.5} & $\begin{array}{l}\text { In which of the following forms is FP counseling } \\
\text { provided? }\end{array}$ & $\begin{array}{l}\text { Several women are counseled } \\
\text { together. }\end{array}$ & 1 & \\
\hline & & $\begin{array}{l}\text { The woman is alone with the } \\
\text { counselor. }\end{array}$ & 2 & \\
\hline & Interviewer: Read options and mark all that apply. & $\begin{array}{l}\text { The woman and her male partner } \\
\text { are counseled together. }\end{array}$ & 3 & \\
\hline & & Other: & 4 & \\
\hline \multirow[t]{2}{*}{3.6} & Are group education sessions conducted for FP & Yes & 1 & \\
\hline & clients? & No & 2 & $\begin{array}{l}\text { next } \\
\text { section }\end{array}$ \\
\hline \multirow[t]{2}{*}{3.7} & Are HIV or STI topics also covered in these & Yes & 1 & \\
\hline & sessions? & No & 2 & \\
\hline
\end{tabular}


4. Description of the service area

\begin{tabular}{|c|c|c|}
\hline No. & QUESTIONS & CODING CATEGORIES \\
\hline 4.1 & Area & \\
\hline 4.2 & Population & \\
\hline 4.3 & Number of women in reproductive age & \\
\hline \multirow[t]{6}{*}{4.4} & \multirow[t]{6}{*}{ Health facilities operating in the district } & Number of hospitals: \\
\hline & & Number of health centers: \\
\hline & & Number of health posts: \\
\hline & & Number of dispensaries: \\
\hline & & Number of other facilities: \\
\hline & & $\begin{array}{l}\text { Interviewer: Specify what is included in this } \\
\text { category: }\end{array}$ \\
\hline
\end{tabular}

\section{Hours of operation}

\begin{tabular}{|c|c|c|c|c|}
\hline No. & QUESTIONS & \multicolumn{3}{|c|}{ CODING CATEGORIES } \\
\hline 5.1 & $\begin{array}{l}\text { Routinely, how many days per week is the facility } \\
\text { open for outpatient services? }\end{array}$ & Days: & & \\
\hline 5.2 & $\begin{array}{l}\text { What are the opening and closing hours for } \\
\text { outpatient services at this facility? }\end{array}$ & $\begin{array}{l}\text { Opening time } \\
\text { Closing time }\end{array}$ & $\bar{l}: \overline{:}=\overline{\text { (Hour : Minutes) }}$ & \\
\hline 5.3 & $\begin{array}{l}\text { Is there a nurse or doctor present at the facility at } \\
\text { all times ( } 24 \text { hours/day)? }\end{array}$ & \begin{tabular}{|l|} 
Yes \\
No \\
\end{tabular} & & $\frac{1}{2}$ \\
\hline 5.4 & $\begin{array}{l}\text { Is there a nurse or doctor available on call at all } \\
\text { times after hours? }\end{array}$ & \begin{tabular}{|l|} 
Yes \\
No \\
\end{tabular} & & $\frac{1}{2}$ \\
\hline
\end{tabular}

6. Services available/staff

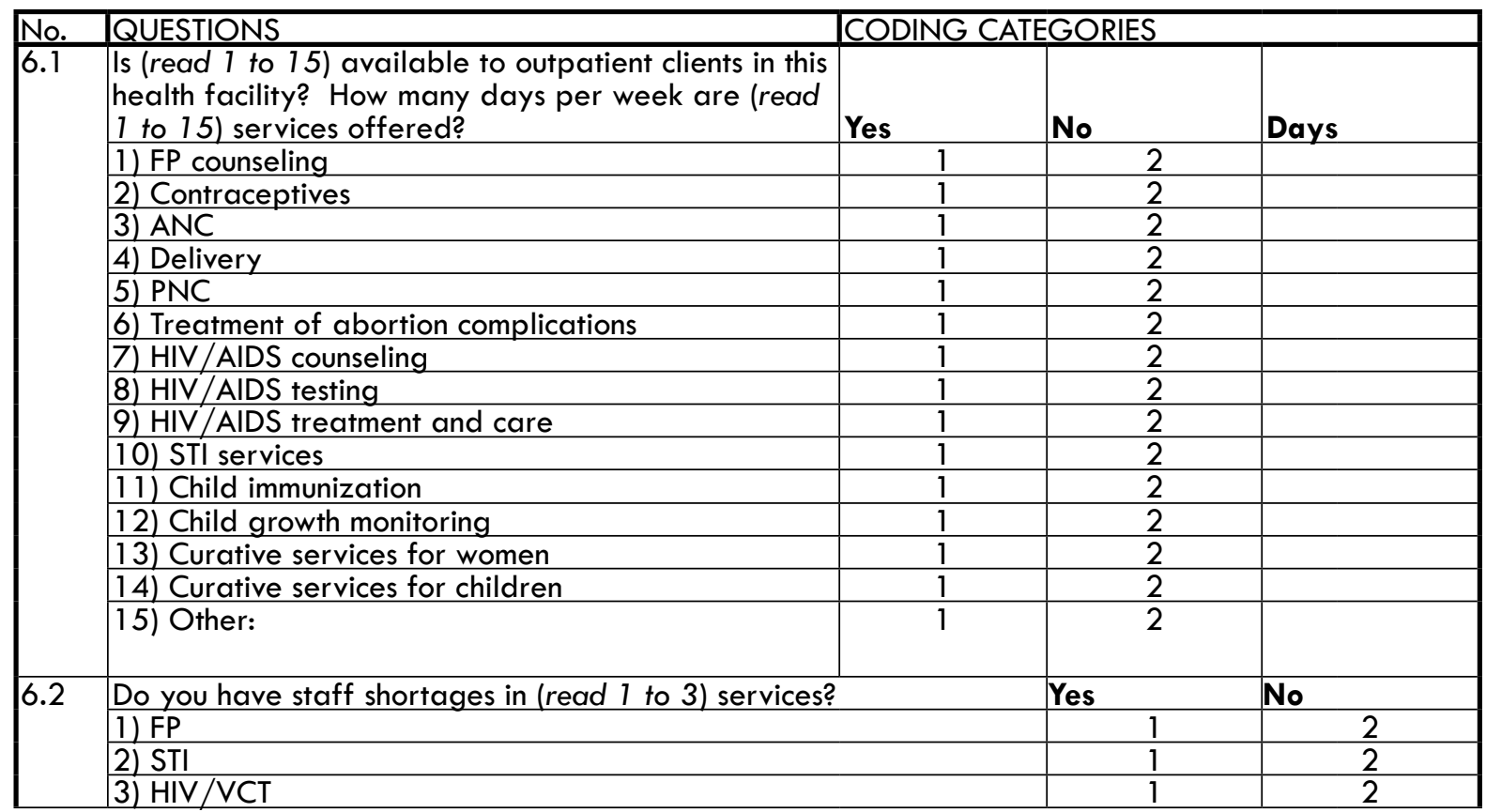




\begin{tabular}{|c|c|c|c|}
\hline \multirow[t]{10}{*}{6.3} & What types of staff shortages are most critical? & Medical specialists & 1 \\
\hline & & General practitioners & 2 \\
\hline & & Medical residents & 3 \\
\hline & & Medical interns & 4 \\
\hline & & Trained midwives & 5 \\
\hline & & Professional nurse & 6 \\
\hline & & Auxiliary nurse & 7 \\
\hline & & Nursing student & 8 \\
\hline & & Social worker & 9 \\
\hline & & Other: & 10 \\
\hline
\end{tabular}

\section{Supervision}

\begin{tabular}{|c|c|c|c|c|}
\hline \multirow{6}{*}{\begin{tabular}{|l|} 
No. \\
7.1
\end{tabular}} & QUESTIONS & \multicolumn{2}{|l|}{ CODING CATEGORIES } & \multirow[t]{5}{*}{ GO TO } \\
\hline & \multirow{5}{*}{$\begin{array}{l}\text { How often do formal meetings to discuss } \\
\text { facility management/administrative issues } \\
\text { take place? }\end{array}$} & Monthly & 1 & \\
\hline & & Quarterly & 2 & \\
\hline & & Semi-annually & 3 & \\
\hline & & Other: & 4 & \\
\hline & & No formal management meetings & 5 & 7.3 \\
\hline \multirow[t]{3}{*}{7.2} & \multirow[t]{2}{*}{ Is an official record of meetings maintained? } & Yes, record seen & 1 & \\
\hline & & Yes, record not seen & 2 & \\
\hline & $\begin{array}{l}\text { Interviewer: If yes, ask to see some record from } \\
\text { most recent meeting. }\end{array}$ & No official record of meetings & 3 & \\
\hline \multirow[t]{2}{*}{7.3} & \multirow{2}{*}{$\begin{array}{l}\text { Does this facility have any system for } \\
\text { determining clients' opinions about the health } \\
\text { facility or services? }\end{array}$} & Yes & 1 & \\
\hline & & No & 2 & 7.6 \\
\hline \multirow[t]{2}{*}{7.4} & \multirow{2}{*}{$\begin{array}{l}\text { In the past } 3 \text { months, have any changes } \\
\text { been made in the facility as a result of client } \\
\text { opinion? }\end{array}$} & Yes & 1 & \\
\hline & & No & 2 & \\
\hline \multirow[t]{2}{*}{7.5} & \multirow{2}{*}{$\begin{array}{l}\text { Does this facility have a method for } \\
\text { monitoring the quality of care provided to } \\
\text { clients? }\end{array}$} & Yes & 1 & \\
\hline & & No & 2 & 7.8 \\
\hline 7.6 & \multicolumn{3}{|l|}{ What is done to monitor quality of care? } & \\
\hline \multirow[t]{5}{*}{7.7} & \multirow{5}{*}{$\begin{array}{l}\text { Are there any indicators for PNC that are } \\
\text { systematically reviewed in these quality- } \\
\text { monitoring activities? }\end{array}$} & Individual service provision staff & 1 & \\
\hline & & Individual supervisors & 2 & \\
\hline & & Internal management/quality team & 3 & \\
\hline & & External management team & 4 & \\
\hline & & Other: & 5 & \\
\hline \multirow[t]{5}{*}{7.8} & \multirow{5}{*}{$\begin{array}{l}\text { Who is responsible for reviewing findings } \\
\text { and taking action relative to quality of care } \\
\text { activities? }\end{array}$} & Individual service provision staff & 1 & \\
\hline & & Individual supervisors & 2 & \\
\hline & & Internal management/quality team & 3 & \\
\hline & & External management team & 4 & \\
\hline & & Other: & 5 & \\
\hline \multirow[t]{3}{*}{7.9} & \multirow{3}{*}{$\begin{array}{l}\text { When was the last time an external } \\
\text { supervisor (someone from outside this facility) } \\
\text { visited the facility? }\end{array}$} & Within the last 6 months & 1 & \multirow[b]{2}{*}{$\begin{array}{l}\text { next } \\
\text { section }\end{array}$} \\
\hline & & More than 6 months ago & 2 & \\
\hline & & No external supervision & 3 & $\begin{array}{l}\text { next } \\
\text { section }\end{array}$ \\
\hline \multirow[t]{7}{*}{7.10} & \multirow{7}{*}{$\begin{array}{l}\text { The last time within the last } 6 \text { months that a } \\
\text { supervisor from outside the facility visited, did } \\
\text { the supervisor do the following: }\end{array}$} & Check records? & 1 & \\
\hline & & Discuss problems? & 2 & \\
\hline & & Discuss policy/administrative issues? & 3 & \\
\hline & & Discuss technical protocols/practice? & 4 & \\
\hline & & Hold an official staff meeting? & 5 & \\
\hline & & $\begin{array}{l}\text { Observe individual staff providing } \\
\text { services? }\end{array}$ & 6 & \\
\hline & & Do anything else? (specify) & 7 & \\
\hline
\end{tabular}


8. Laboratory tests

\begin{tabular}{|c|c|c|c|c|c|c|}
\hline \multirow{3}{*}{\begin{tabular}{|l} 
No. \\
8.1
\end{tabular}} & QUESTIONS & \multicolumn{5}{|c|}{ CODING CATEGORIES } \\
\hline & \multicolumn{6}{|c|}{ Are the following tests available to clients in this health facility? } \\
\hline & Type of test & $\begin{array}{l}\text { Conduct } \\
\text { test }\end{array}$ & $\begin{array}{l}\text { Collect } \\
\text { specimen }\end{array}$ & $\begin{array}{l}\text { Test is } \\
\text { referred }\end{array}$ & \multicolumn{2}{|c|}{$\begin{array}{l}\text { Test is not } \\
\text { offered }\end{array}$} \\
\hline & HIV preliminary tests & 1 & 2 & 3 & \multicolumn{2}{|c|}{4} \\
\hline & HIV confirmation tests & 1 & 2 & 3 & \multicolumn{2}{|c|}{4} \\
\hline & Syphilis & 1 & 2 & 3 & \multicolumn{2}{|c|}{4} \\
\hline & Gonorrhea/chlamydia & 1 & 2 & 3 & \multicolumn{2}{|c|}{4} \\
\hline & Test for blood anemia & 1 & 2 & 3 & \multicolumn{2}{|c|}{4} \\
\hline & Test urine for protein & 1 & 2 & 3 & \multicolumn{2}{|c|}{4} \\
\hline & Test urine glucose & 1 & 2 & 3 & \multicolumn{2}{|c|}{4} \\
\hline & Malaria & 1 & 2 & 3 & \multicolumn{2}{|c|}{4} \\
\hline & Blood group & 1 & 2 & 3 & \multicolumn{2}{|c|}{4} \\
\hline & TB & 1 & 2 & 3 & \multicolumn{2}{|c|}{4} \\
\hline & Cervical smear & 1 & 2 & 3 & \multicolumn{2}{|c|}{4} \\
\hline & Pregnancy test & 1 & 2 & 3 & \multicolumn{2}{|c|}{4} \\
\hline \multirow[t]{2}{*}{8.2} & \multirow{2}{*}{\multicolumn{2}{|c|}{$\begin{array}{l}\text { Does the facility have the ability to do viral load counts to } \\
\text { monitor HIV/AIDS, or is blood sent to another facility? }\end{array}$}} & \multicolumn{4}{|c|}{ Yes, at this facility } \\
\hline & & & No, sent to & another $\mathrm{fc}$ & & 2 \\
\hline \multirow[t]{2}{*}{8.3} & \multirow{2}{*}{\multicolumn{2}{|c|}{$\begin{array}{l}\text { Does the facility have the ability to do CD4 counts to monitor } \\
\text { HIV/AIDS, or is blood sent to another facility? }\end{array}$}} & \multicolumn{4}{|c|}{ Yes, at this facility } \\
\hline & & & No, sent to & another $\mathrm{fc}$ & & 2 \\
\hline \multirow[t]{2}{*}{8.4} & \multirow{2}{*}{\multicolumn{2}{|c|}{ Does the facility have a DOTS program for TB? }} & \multicolumn{4}{|l|}{ Yes } \\
\hline & & & No & & & 2 \\
\hline
\end{tabular}

9. General infrastructure of the facility

\begin{tabular}{|l|l|l|}
\hline No. & QUESTIONS & CODING CATEGORIES
\end{tabular}

9.1 Interviewer: Observe the conditions and infrastructure in the facility and mark whether it has the following.

1) Piped running water

2) Electricity

3) Working latrines/toilets for clients

4) Working phone/short wave radio

5) Transport vehicle or standing arrangements for transport in the case of emergencies

6) Clean facilities (e.g., the floors are swept, there is no dust in the desks)

7) Enough chairs or benches in waiting areas

8) Waiting area for clients where they are protected from the sun, rain, and snow

10. Conditions of FP area

\begin{tabular}{l|l|l}
\hline No. & QUESTIONS & CODING CATEGORIES \\
\hline
\end{tabular}

10.1 Interviewer: Ask to see the room where FP counseling is given. For the following items, check whether

the item is in the room where the examination is conducted or in an adjacent room.

Describe the setting for the examination $\quad$ Private room

room.

Room with other people with separating

barrier

Room with other people and no visual barrier

No

\begin{tabular}{|r|r|}
\hline Yes & No \\
\hline 1 & 2 \\
\hline 1 & 2 \\
\hline 1 & 2 \\
\hline 1 & 2 \\
1 & 2 \\
\hline 1 & 2 \\
\hline 1 & 2 \\
\hline 1 & 2 \\
\hline
\end{tabular}

10.2 Mark whether the area satisfies the following conditions:

(1) Visual privacy

(2) Auditory privacy

Yes

\begin{tabular}{l|l} 
Yes & No
\end{tabular}

10.3 Is there a visible sign outside the FP area announcing that FP services are available?

10.4 Is there a visible sign announcing that FP services are available elsewhere in the outpatient services area?

\begin{tabular}{l|r}
1 & 2 \\
1 & 2
\end{tabular}

\begin{tabular}{|l|l|}
\hline Yes & 1 \\
\hline No & 2 \\
\hline Yes, where?: & 1 \\
\hline No & 2 \\
\hline
\end{tabular}


11. Availability and resupply of HIV rapid tests

\begin{tabular}{|l|l|l|l|}
\hline No. & QUESTIONS & CODING CATEGORIES \\
\hline 11.1 & Are HIV rapid test kits available in the facility? & Yes, observed & 1 \\
\cline { 3 - 4 } & & Yes, not observed & 2 \\
\cline { 3 - 4 } 11.2 & Are HIV rapid test kits ordered from the same supplier as & Yes & 3 \\
\cline { 3 - 4 } & No & 1 \\
\hline 11.3 & From whom are they ordered? & & 2 \\
\hline 11.4 & $\begin{array}{l}\text { Are HIV rapid test kits and contraceptive supplies ordered in } \\
\text { the same way? }\end{array}$ & Yes & No \\
\hline 11.5 & How are rapid tests ordered? & & 2 \\
\hline
\end{tabular}

12. Condom dispensers

Interviewer: Collect information on the location and accessibility of condoms at the facility. A condom dispenser can be any container that the facility uses to put condoms in for ease of accessibility. Examples of dispensers are a cardboard box or a bowl.

\begin{tabular}{|l|l|l|l|l|l|l|}
\hline \multirow{2}{*}{$\begin{array}{l}\text { Location of } \\
\text { dispenser }\end{array}$} & Appropriateness of location & $\begin{array}{l}\text { Designated } \\
\text { person to } \\
\text { check and fill }\end{array}$ & $\begin{array}{l}\text { How often } \\
\text { checked }\end{array}$ & $\begin{array}{l}\text { When last } \\
\text { checked }\end{array}$ & $\begin{array}{l}\text { Condoms } \\
\text { currently in } \\
\text { dispenser }\end{array}$ \\
\hline & & & & & \\
\hline & & & & & \\
\hline & & & & & & \\
\hline & & & & & & \\
\hline
\end{tabular}

* Visibility: Dispenser is located in a place where clients can easily find it.

** Privacy: Dispenser is located in an area where clients can get condoms without being observed by other clients/providers.

\section{IEC materials}

No. QQUESTIONS

13.1 Interviewer: Verify that the following materials are available in the FP counseling or examination room.

Visual aids for teaching about:

1) Different FP methods

2) Dual protection

3) STIs prevention

4) HIV/AIDS prevention

5) HIV/AIDS treatment and care

6) PMTCT

13.2 Information booklets/leaflets for clients to take home:

1) Different FP methods

2) Dual protection

3) STIs prevention

4) HIV/AIDS prevention

5) HIV/AIDS treatment and care

6) PMTCT CODING CATEGORIES

\begin{tabular}{|c|c|}
\hline Yes & No \\
\hline 1 & 2 \\
\hline 1 & 2 \\
\hline 1 & 2 \\
\hline 1 & 2 \\
\hline 1 & 2 \\
\hline 1 & 2 \\
\hline Yes & No \\
\hline 1 & 2 \\
\hline 1 & 2 \\
\hline 1 & 2 \\
\hline 1 & 2 \\
\hline 1 & 2 \\
\hline 1 & 2 \\
\hline
\end{tabular}


14. Record keeping

\begin{tabular}{|c|c|c|c|c|c|c|}
\hline No. & QUESTIONS & & CODINC & EGORIES & & GO TO \\
\hline 14.1 & Do women who receive FP services in & his health facility & Yes & & 1 & \\
\hline & receive a record card they carry wit & them? & No & & 2 & 14.3 \\
\hline 14.2 & What information is recorded in this & $\operatorname{ard} ?$ & Informa & recorded & & \\
\hline & & & Yes & No & & \\
\hline & 1) Client's name & & 1 & 2 & & \\
\hline & 2) Date of last visit & & 1 & 2 & & \\
\hline & 3) Whether client has received FP m & hod & 1 & 2 & & \\
\hline & 4) Method delivered & & 1 & 2 & & \\
\hline & 5) Whether client has received HIV/ & DS counseling & 1 & 2 & & \\
\hline & 6) Whether client has received HIV & & 1 & 2 & & \\
\hline & 7) Whether client has received STI c & nseling & 1 & 2 & & \\
\hline & 8) Date of future visit & & 1 & 2 & & \\
\hline 14.3 & Is there a record where information & Yes. Where? & & & 1 & \\
\hline & & No & & & 2 & \\
\hline
\end{tabular}

\section{Service statistics}

\begin{tabular}{|c|c|c|c|c|c|}
\hline \multirow{3}{*}{\begin{tabular}{|l|} 
No. \\
15.1
\end{tabular}} & QUESTIONS & \multicolumn{4}{|c|}{ CODING CATEGORIES } \\
\hline & $\begin{array}{l}\text { Interviewer: Ask to see the service statistics and obtain the } \\
\text { following information from them. }\end{array}$ & $\begin{array}{l}\text { Last } 12 \\
\text { months }\end{array}$ & $\begin{array}{l}\text { Last } 6 \\
\text { months }\end{array}$ & $\begin{array}{l}\text { Last } \\
\text { month }\end{array}$ & $\begin{array}{l}\text { Info not } \\
\text { available }\end{array}$ \\
\hline & $\begin{array}{l}\text { 1) General information on FP (should be availab from the } \\
\text { FP records) }\end{array}$ & & & & \\
\hline & 2) Number of women who received FP services & & & & \\
\hline & 3) Number of first-time FP visitors & & & & \\
\hline & 4) Number of repeat FP visitors & & & & \\
\hline & 5) Number of FP clients referred for HIV testing & & & & \\
\hline & 6) Number of FP clients referred for STI services & & & & \\
\hline 15.2 & 1) VCT (should be available from the testing records) & & & & \\
\hline & 2) Number of VCT clients & & & & \\
\hline & 3) Number of VCT clients who were tested & & & & \\
\hline & 4) Number of clients receiving results & & & & \\
\hline & 5) Number of clients who tested positive & & & & \\
\hline & 6) Number referred for other services & & & & \\
\hline & 7) Number referred to community or support groups & & & & \\
\hline
\end{tabular}




\section{B. Observation guide}

\section{INSTRUCTIONS TO DATA}

COLLECTOR: Before proceeding to observe the interaction between client and provider, use the greeting below to explain to the provider that you will be observing him while he attends to his/her clients and to make sure that she/he knows that you are not there to evaluate her/him and that you are not an "expert" who can be consulted during the session. Then obtain the client's informed consent. When observing, be as discreet as possible: try to sit so that you are behind the client but not directly in view of the provider, and make notes quickly. For each question, describe or circle the code of the response that most appropriately represents your observation of what happened during the interaction. As discussed during the training, you may witness behavior that poses a serious risk to the client's health. Please keep in mind the guidelines for when to intervene in the consultation on behalf of the client's welfare.

\section{GREETING FOR THE PROVIDER:}

My name is , and I work with , where we are conducting a study

to see what information clients are given during their family planning visits. This information will help us to propose ways in which to improve the services offered. As a part of this study, we are observing the interaction of health providers and their clients during family planning visits. I will observe silently as you attend to your clients and take notes. I am in no way an expert in your area, and I am not here to evaluate your work. I will not make any comments or interfere in your consultations in any way.

Your participation in this component of the study will remain confidential. I will not record your name in the notes I take. This way, no one will be able to know that I observed your appointments. Do I have your permission?
INFORMED CONSENT FORM FOR THE CLIENT: My name is , and I work

with , where we are conducting a study to see what information clients are given during their FP visits. This information will help us to propose ways in which to improve the services offered. As a part of this study, we are observing the interaction of health providers and their clients during FP visits. I would appreciate it if you allowed me to observe your appointment today. If you do, I will be accompanying you through your visit and seeing what you and your provider talk about. I will also observe when he examines you. I am not a health provider in this facility and will not making any comments or participating in your consultations in any way. At the end of your visit, I will, if you allow me to, ask you some questions regarding your experience during your visit. This interview will be private, and none of the providers that see you today will be present.

However, your participation in this study is voluntary, and you can choose not to let me accompany you or not to answer my questions. If you choose not to participate in either component of the study, you will not be penalized in any way. If you agree to participate and you change your opinion later, you can also ask me to exit the room whenever you want.

If you participate, you will not receive money or gifts, and you will not benefit directly from your participation. However, your participation will result in improved future maternal and reproductive health services.

Your participation in this study will remain confidential. I will not record your name in the notes I take. This way, no one will be able to know that I observed your appointments.

Finally, if you have any questions about this study at a later stage, you can come back here and clear your doubts with your provider at the clinic. Do you accept to participate in this study? 
1. Facility identification

\begin{tabular}{|c|c|c|c|}
\hline No. & QUESTIONS & \multicolumn{2}{|l|}{ CODING CATEGORIES } \\
\hline 1.1 & Date of observations & \multicolumn{2}{|l|}{ (Day/ Month/ Year) } \\
\hline 1.2 & Facility name & \multirow{2}{*}{\multicolumn{2}{|c|}{ (2) }} \\
\hline 1.3 & City or locality & & \\
\hline \multirow[t]{7}{*}{1.4} & \multirow{7}{*}{ Type of facility } & Hospital & 1 \\
\hline & & Health center with maternity ward & 2 \\
\hline & & Health center without maternity ward & 3 \\
\hline & & Health post with maternity ward & 4 \\
\hline & & Health post without maternity ward & 5 \\
\hline & & Dispensary & 6 \\
\hline & & Other: & 7 \\
\hline \multirow[t]{4}{*}{1.5} & \multirow{4}{*}{ Type of sector } & Government & 1 \\
\hline & & NGO & 2 \\
\hline & & Private & 3 \\
\hline & & Other: & 4 \\
\hline \multirow[t]{4}{*}{1.6} & \multirow[t]{4}{*}{ Result of the observation } & Complete & 1 \\
\hline & & Incomplete & 2 \\
\hline & & Refused & 3 \\
\hline & & Other: & 4 \\
\hline
\end{tabular}

2. Integration of FP services and HIV/AIDS and STI prevention and detection

\begin{tabular}{|c|c|c|c|}
\hline No. & QUESTIONS & CODING & SORIES \\
\hline & & Yes & No \\
\hline 2.1 & Discuss STI/HIV/AIDS symptoms/signs. & 1 & 2 \\
\hline 2.2 & Explain that STIs may be asymptomatic. & 1 & 2 \\
\hline 2.3 & Ask client about presence of STI/HIV symptoms. & 1 & 2 \\
\hline 2.4 & $\begin{array}{l}\text { Advise client to seek medical treatment if they notice any symptoms } \\
\text { of an STI. }\end{array}$ & 1 & 2 \\
\hline 2.5 & Discuss STI/HIV risk factors: & Yes & No \\
\hline & 1) Unprotected sex (no condom use) & 1 & 2 \\
\hline & 2) Multiple concurrent partners & 1 & 2 \\
\hline & 3) Partner with multiple partners & 1 & 2 \\
\hline 2.6 & Explain that STIs increase HIV risk. & 1 & 2 \\
\hline 2.7 & Explain that condoms reduce HIV risk. & 1 & 2 \\
\hline 2.8 & Explain that abstinence reduces HIV risk. & 1 & 2 \\
\hline 2.9 & $\begin{array}{l}\text { Encourage the use of condoms for STI/HIV prevention along with } \\
\text { the use of another FP method. }\end{array}$ & 1 & 2 \\
\hline 2.10 & Explain how to use a condom. & 1 & 2 \\
\hline 2.11 & Explain PMTCT. & 1 & 2 \\
\hline 2.11 & Ask client about their STI/HIV risk factors. & 1 & 2 \\
\hline 2.12 & Discuss HIV testing: & Yes & No \\
\hline & 1) Ask whether client has ever been tested for HIV. & 1 & 2 \\
\hline & 2) Ask date of last test. & 1 & 2 \\
\hline & 3) Ask client's status. & 1 & 2 \\
\hline & 4) Does the client disclose her/his status? & 1 & 2 \\
\hline & 5) Offer VCT. & 1 & 2 \\
\hline
\end{tabular}

\section{Integration of FP and HIV services for HIV-positive clients}

\begin{tabular}{|c|c|c|c|}
\hline No. & QUESTIONS & \multicolumn{2}{|c|}{ CODING CATEGORIES } \\
\hline & & Yes & No \\
\hline 3.1 & $\begin{array}{l}\text { Screen for symptoms of TB (chronic cough, weight loss, and night } \\
\text { sweats). }\end{array}$ & 1 & 2 \\
\hline 3.2 & If TB negative, ask whether they have started prophylaxis. & 1 & 2 \\
\hline 3.3 & If TB positive, ask whether they been referred to a TB clinic. & 1 & 2 \\
\hline 3.4 & Ask about CD 4 count. & 1 & 2 \\
\hline 3.5 & Ask about ARV treatment. & 1 & 2 \\
\hline
\end{tabular}


4. Integration of FP and HIV services for HIV-negative or HIV-unknown clients

\begin{tabular}{|l|l|l|l|}
\hline No. & QUESTIONS & \multicolumn{2}{l|}{ CODING CATEGORIES } \\
\hline & \multicolumn{1}{|l|}{ Yes } & No \\
\hline 4.1 & Discuss where to go for VCT services. & 1 & 2 \\
\hline 4.2 & Discuss client's interest in getting tested. & 1 & 2 \\
\hline 4.3 & Refer client to another facility for VCT. & 1 & 2 \\
\hline 4.4 & Test client for HIV. & 1 & 2 \\
\hline 4.5 & Suggest that partner gets tested for HIV. & 1 & 2 \\
\hline
\end{tabular}

5. Quality of FP counseling

\begin{tabular}{|c|c|c|c|c|}
\hline \multirow{8}{*}{$\frac{\text { No. }}{5.1}$} & QUESTIONS & \multicolumn{2}{|c|}{ CODING CATEGORIES } & \multirow[t]{8}{*}{ GO TO } \\
\hline & Which IEC materials are used during the consultation? & Used & Not used & \\
\hline & 1) Flip chart & 1 & 2 & \\
\hline & 2) Brochures/leaflet & 1 & 2 & \\
\hline & 3) Contraceptive samples (e.g., pills, condom) & 1 & 2 & \\
\hline & 4) Posters & 1 & 2 & \\
\hline & 5) Anatomical models & 1 & 2 & \\
\hline & 6) Other: & 1 & 2 & \\
\hline \multirow[t]{18}{*}{5.2} & Which methods were discussed during the consultation? & Yes & No & \\
\hline & Combined oral contraceptives & 1 & 2 & \\
\hline & Minipills (progestin-only pills) & 1 & 2 & \\
\hline & Emergency contraceptive pills & 1 & 2 & \\
\hline & Progestin-only injectables (injection every 2 or 3 months) & 1 & 2 & \\
\hline & Jadelle Implants & 1 & 2 & \\
\hline & Implanon implants & 1 & 2 & \\
\hline & Sinoplant (II) implants & 1 & 2 & \\
\hline & IUD & 1 & 2 & \\
\hline & IUS & 1 & 2 & \\
\hline & Male condoms & 1 & 2 & \\
\hline & Diaphragms & 1 & 2 & \\
\hline & Cervical caps & 1 & 2 & \\
\hline & Female sterilization & 1 & 2 & \\
\hline & Vasectomy & 1 & 2 & \\
\hline & Fertility awareness methods & 1 & 2 & \\
\hline & Withdrawal & 1 & 2 & \\
\hline & Other: & 1 & 2 & \\
\hline \multirow[t]{2}{*}{5.3} & \multirow{2}{*}{$\begin{array}{l}\text { Did the provider promote or emphasize one method in } \\
\text { particular? }\end{array}$} & Yes & 1 & \\
\hline & & No & 2 & 5.5 \\
\hline \multirow[t]{17}{*}{5.4} & & & \begin{tabular}{|l|l|} 
Not \\
emphasized
\end{tabular} & 0.0 \\
\hline & $\begin{array}{l}\text { If yes, which method did the provider emphasize? } \\
\text { Combined oral contraceptives }\end{array}$ & Emphasized & emphasized & \\
\hline & Minipills (progestin-only pills) & 1 & $\frac{2}{2}$ & \\
\hline & Emergency contraceptive pills & 1 & 2 & \\
\hline & Progestin-only injectables (injection every 2 or 3 months) & 1 & 2 & \\
\hline & Jadelle implants & 1 & 2 & \\
\hline & Implanon implants & 1 & 2 & \\
\hline & Sinoplant (II) implants & 1 & 2 & \\
\hline & IUD & 1 & 2 & \\
\hline & IUS & 1 & 2 & \\
\hline & Male condoms & 1 & 2 & \\
\hline & Diaphragms & 1 & 2 & \\
\hline & Cervical caps & 1 & 2 & \\
\hline & Female sterilization & 1 & 2 & \\
\hline & Vasectomy & 1 & 2 & \\
\hline & Fertility awareness methods & 1 & 2 & \\
\hline & Withdrawal & 1 & 2 & \\
\hline \multirow{2}{*}{5.5} & \multirow{2}{*}{$\begin{array}{l}\text { Did the client mention a preference for a particular method } \\
\text { without being asked? }\end{array}$} & Yes & 1 & \\
\hline & & No & 2 & \\
\hline \multirow[t]{2}{*}{5.6} & \multirow{3}{*}{$\begin{array}{l}\text { Did the provider ask the client which method she would prefer } \\
\text { to use? }\end{array}$} & Yes & 1 & \\
\hline & & No & 2 & \\
\hline \multirow[t]{2}{*}{5.7} & & Yes & 1 & \\
\hline & Did the client decide to use (switch to) a contraceptive method? & No & 2 & \\
\hline
\end{tabular}




\begin{tabular}{|c|c|c|c|c|}
\hline 5.8 & $\begin{array}{l}\text { If not, what is the main reason the client did not choose a } \\
\text { method? }\end{array}$ & Yes & No & \\
\hline & Came for info only & 1 & 2 & \\
\hline & Changed mind & 1 & 2 & \\
\hline & Pregnancy suspected & 1 & 2 & \\
\hline & Medical contraindications & 1 & 2 & \\
\hline & Other health reasons & 1 & 2 & \\
\hline & Method not available & 1 & 2 & \\
\hline & Was happy with current method & 1 & 2 & \\
\hline & Other: & 1 & 2 & \\
\hline 5.9 & What method did the client decide to use? & Yes & No & \\
\hline & Combined oral contraceptives & 1 & 2 & \\
\hline & Minipills (progestin-only pills) & 1 & 2 & \\
\hline & Emergency contraceptive pills & 1 & 2 & \\
\hline & Progestin-only injectables (injection every 2 or 3 months) & 1 & 2 & \\
\hline & Jadelle implants & 1 & 2 & \\
\hline & Implanon implants & 1 & 2 & \\
\hline & Sinoplant implants & 1 & 2 & \\
\hline & IUD & 1 & 2 & \\
\hline & IUS & 1 & 2 & \\
\hline & Male condoms & 1 & 2 & \\
\hline & Diaphragms & 1 & 2 & \\
\hline & Cervical caps & 1 & 2 & \\
\hline & Female sterilization & 1 & 2 & \\
\hline & Vasectomy & 1 & 2 & \\
\hline & Fertility awareness methods & 1 & 2 & \\
\hline & Withdrawal & 1 & 2 & \\
\hline 5.10 & Did the provider: & Yes & No & \\
\hline & Explain how method works and how it is used? & 1 & 2 & \\
\hline & Explain advantages of method? & 1 & 2 & \\
\hline & Explain disadvantages of method? & 1 & 2 & \\
\hline & Explain reversibility of method? & 1 & 2 & \\
\hline & Explain possible side-effects of method? & 1 & 2 & \\
\hline & Discuss client's fears and concerns about method? & 1 & 2 & \\
\hline 5.11 & Did the client receive her/his preferred method? & Yes & 1 & 5.14 \\
\hline & & No & 2 & \\
\hline 5.12 & Why did the client not receive her preferred method? & Yes & No & \\
\hline & Referred to another place for method & 1 & 2 & \\
\hline & Client to return with menses & 1 & 2 & \\
\hline & Method out of stock & 1 & 2 & \\
\hline & Client to return for procedure & 1 & 2 & \\
\hline & Other: & 1 & 2 & \\
\hline 5.13 & $\begin{array}{l}\text { Was an alternative method provided to the client to use while } \\
\text { waiting to receive her method of choice? Which method was } \\
\text { given? }\end{array}$ & Yes & No & \\
\hline & None & 1 & 2 & \\
\hline & Combined oral contraceptives & 1 & 2 & \\
\hline & Minipills (progestin-only pills) & 1 & 2 & \\
\hline & Emergency contraceptive pills & 1 & 2 & \\
\hline & Progestin-only injectables (injection every 2 or 3 months) & 1 & 2 & \\
\hline & Jadelle implants & 1 & 2 & \\
\hline & Implanon implants & 1 & 2 & \\
\hline & Sinoplant (II) implants & 1 & 2 & \\
\hline & IUD & 1 & 2 & \\
\hline & IUS & 1 & 2 & \\
\hline & Male condoms & 1 & 2 & \\
\hline & Diaphragms & 1 & 2 & \\
\hline & Cervical caps & 1 & 2 & \\
\hline & Female sterilization & 1 & 2 & \\
\hline & Vasectomy & 1 & 2 & \\
\hline & Fertility awareness methods & 1 & 2 & \\
\hline & Withdrawal & 1 & 2 & \\
\hline & Others: & 1 & 2 & \\
\hline
\end{tabular}




\begin{tabular}{|l|l|l|c|c|}
5.14 & Was the client told when to return for a resupply or a follow-up? & Yes & 1 & \\
\cline { 3 - 4 } & No & 2 & \multicolumn{2}{|c|}{$\begin{array}{c}\text { next } \\
\text { section }\end{array}$} \\
\hline & & Yes & No \\
\hline If yes, where? & 1 & 2 \\
\hline This facility & 1 & 2 \\
\hline Another health facility & 1 & 2 \\
\hline Pharmacy/private doctor & & 1 & \\
\hline Other: & & \\
\hline
\end{tabular}

6. Medical procedures performed

\begin{tabular}{|c|c|c|c|c|}
\hline \multirow{3}{*}{\begin{tabular}{|l|} 
No. \\
6.1
\end{tabular}} & \multirow{3}{*}{$\begin{array}{l}\text { QUESTIONS } \\
\text { Was a pelvic examination performed? }\end{array}$} & \multicolumn{2}{|c|}{ CODING CATEGORIES } & \multirow[t]{2}{*}{ GO TO } \\
\hline & & Yes & 1 & \\
\hline & & No & 2 & 6.3 \\
\hline \multirow[t]{10}{*}{6.2} & If yes, did the provider: & Yes & No & \\
\hline & 1) Inform the client what would happen before the exam? & 1 & 2 & \\
\hline & 2) Wash hands before the exam? & 1 & 2 & \\
\hline & 3) Use new or disinfected gloves? & 1 & 2 & \\
\hline & 4) Visually inspect external genitalia? & 1 & 2 & \\
\hline & 5) Take a pap smear/specimen? & 1 & 2 & \\
\hline & 6) Perform a digital/bimanual examination? & 1 & 2 & \\
\hline & 7) Wash hands after the exam? & 1 & 2 & \\
\hline & 8) Inform the client about the results of the exam? & 1 & 2 & \\
\hline & 9) Use sterilized or disinfected instruments? & 1 & 2 & \\
\hline \multirow[t]{3}{*}{6.3} & If a speculum examination was performed, did the provider: & Yes & No & \\
\hline & 1) Use a clean speculum? & 1 & 2 & \\
\hline & 2) Use new or disinfected gloves? & 1 & 2 & \\
\hline \multirow[t]{4}{*}{6.4} & If an IUD was inserted, did the provider: & Yes & No & \\
\hline & 1) Sound the uterus? & 1 & 2 & \\
\hline & 2) Handle the IUD with aseptic procedures? & 1 & 2 & \\
\hline & 3) Use new or disinfected gloves? & 1 & 2 & \\
\hline \multirow[t]{4}{*}{6.5} & If an injectable was given, did the provider: & Yes & No & \\
\hline & 1) Disinfect the injection site? & 1 & 2 & \\
\hline & 2) Use a sterile needle? & 1 & 2 & \\
\hline & 3) Massage the injection site? & 1 & 2 & \\
\hline
\end{tabular}

7. Other health issues

\begin{tabular}{|c|c|c|c|}
\hline \multirow{2}{*}{\begin{tabular}{|l} 
No. \\
7.1
\end{tabular}} & \multirow{2}{*}{$\begin{array}{l}\text { QUESTIONS } \\
\text { During the consultation, did any provider take or perform any } \\
\text { of these actions? }\end{array}$} & \multicolumn{2}{|c|}{ CODING CATEGORIES } \\
\hline & & Yes & No \\
\hline & 1) Assess weight & 1 & 2 \\
\hline & 2) Perform/refer for pregnancy test & 1 & 2 \\
\hline & 3) Perform general physical exam & 1 & 2 \\
\hline & 4) Perform/request/refer for blood test & 1 & 2 \\
\hline & 5) Perform a breast exam & 1 & 2 \\
\hline & 6) Perform/request/refer for blood test for a pap smear & 1 & 2 \\
\hline & 7) Perform a syndromic analysis for STIs & 1 & 2 \\
\hline 7.2 & $\begin{array}{l}\text { What other health issues were discussed with the client during } \\
\text { the consultation? }\end{array}$ & Yes & No \\
\hline & 1) Gynecological exam/pap smear & 1 & 2 \\
\hline & 2) Pregnancy testing & 1 & 2 \\
\hline & 3) PMTCT & 1 & 2 \\
\hline & 4) Gender-based violence/partner's abuse & 1 & 2 \\
\hline & 5) Curative services & 1 & 2 \\
\hline & 6) Other: & 1 & 2 \\
\hline
\end{tabular}




\section{Client exit interview}

\section{INSTRUCTIONS FOR THE}

INTERVIEWERS: Approach all women as they leave the area where FP services are provided, and asked them whether they are willing to be asked a few questions about the services they received today. If they accept, make sure that you are in a place that guarantees privacy and where the woman is comfortable. Ask them for their informed consent to be interviewed (read the form below). Interview only women who give their informed consent. For each item in the interview, circle the code of the adequate response or describe, as appropriate.

\section{INFORMED CONSENT FORM FOR THE} CLIENT: My name is , and I work with , where we are conducting a study to see what information clients are given during their FP services. This information will help us to propose ways in which to improve the services offered. As a part of this study, we are interviewing women who visited the facility for FP services today. In these interviews, we ask them about the services and information they obtained, their satisfaction with the services received, their plans for having more children in the future, and other health needs they may have.
I would appreciate it if you allowed me to ask you some questions. The interview will be private, and none of the providers that saw you today will be present.

However, your participation in this study is voluntary, and you can choose not to let me interview you. If you choose not to participate in our study, you will not be penalized in any way. If you accept to participate and you change your opinion later, you can also ask me to interrupt the interview whenever you want.

If you participate, you will not receive money or gifts, and you will not benefit directly from your participation. However, your participation will result in improved future maternal and reproductive health services.

Your participation in this study will remain confidential. I will not record your name in the questionnaire. This way, no one will be able to know that I observed your appointments.

Finally, if you have any questions about this study at a later stage, you can come back here and clear your doubts with your provider at the clinic. Do you accept to participate in this study?

1. Facility identification

\begin{tabular}{|c|c|c|c|}
\hline No. & QQUESTIONS & \multicolumn{2}{|l|}{ CODING CATEGORIES } \\
\hline$\overline{1.1}$ & Date of interview & \multicolumn{2}{|l|}{ (Day/ Month/ Year) } \\
\hline 1.2 & Facility name & & \\
\hline 1.3 & City or locality & & \\
\hline 1.4 & Type of facility & Hospital & 1 \\
\hline & & Health center with maternity ward & 2 \\
\hline & & Health center without maternity ward & 3 \\
\hline & & Health post with maternity ward & 4 \\
\hline & & Health post without maternity ward & 5 \\
\hline & & Dispensary & 6 \\
\hline & & Other: & 7 \\
\hline 1.5 & Type of sector & Government & 1 \\
\hline & & NGO & 2 \\
\hline & & Private & 3 \\
\hline & & Other: & 4 \\
\hline 1.6 & Result of the interview & Complete & 1 \\
\hline & & Incomplete & 2 \\
\hline & & Refused & 3 \\
\hline & & Other: & 4 \\
\hline
\end{tabular}


2. HIV services received during this visit

\begin{tabular}{|c|c|c|c|c|c|}
\hline \multirow{5}{*}{$\frac{\text { No. }}{2.1}$} & \multirow{5}{*}{$\begin{array}{l}\text { QUESTIONS } \\
\text { During your visit to this health facility, did a } \\
\text { health provider talk to you about STIs and/or } \\
\text { HIV/AIDS? }\end{array}$} & \multicolumn{3}{|c|}{ CODING CATEGORIES } & GO TO \\
\hline & & \multicolumn{2}{|c|}{ Yes, about HIV/AIDS } & 1 & \\
\hline & & \multicolumn{2}{|c|}{ Yes, about STIs } & 2 & \\
\hline & & \multirow{2}{*}{\multicolumn{2}{|c|}{ Don't know }} & 3 & \\
\hline & & & & & \\
\hline & Interviewer: Mark all that apply. & \multirow[b]{3}{*}{$\begin{array}{l}\text { Not } \\
\text { prompted }\end{array}$} & & & \\
\hline \multirow[t]{8}{*}{2.2} & If yes, what did the provider tell you? & & & & \\
\hline & $\begin{array}{l}\text { Interviewer: Mark spontaneous responses, then } \\
\text { ask about remaining items. }\end{array}$ & & Prompted & Don't know & \\
\hline & $\begin{array}{l}\text { 1) Having multiple sex partners increases } \\
\text { STI/HIV risk. }\end{array}$ & 1 & 2 & 98 & \\
\hline & $\begin{array}{l}\text { 2) STI/HIV risk is high if partner has multiple } \\
\text { sex partners. }\end{array}$ & 1 & 2 & 98 & \\
\hline & 3) Using condoms reduces STI/HIV risk. & 1 & 2 & 98 & \\
\hline & 4) Abstinence reduces STI/HIV risk. & 1 & 2 & 98 & \\
\hline & 5) Recommended an STI/HIV test for me. & 1 & 2 & 98 & \\
\hline & $\begin{array}{l}\text { 6) Recommended an STI/HIV test for my } \\
\text { partner. }\end{array}$ & 1 & 2 & 98 & \\
\hline \multirow[t]{3}{*}{2.3} & \multirow{3}{*}{$\begin{array}{l}\text { During your visit to this health facility, did a } \\
\text { health provider offer you an HIV test at this } \\
\text { clinic or a referral for HIV testing? }\end{array}$} & \multicolumn{2}{|c|}{ Yes, take the test at the clinic } & 1 & \\
\hline & & \multicolumn{2}{|c|}{$\begin{array}{l}\text { Yes, a referral to a other } \\
\text { clinic }\end{array}$} & 2 & \\
\hline & & \multicolumn{2}{|c|}{ No } & 3 & 2.11 \\
\hline \multirow[t]{3}{*}{2.4} & Who offered you HIV testing today? & \multicolumn{2}{|l|}{ Nurse } & 1 & \\
\hline & & \multirow{2}{*}{\multicolumn{2}{|c|}{\begin{tabular}{|l|} 
Counselor \\
Other:
\end{tabular}}} & 2 & \\
\hline & & & & 3 & \\
\hline \multirow[t]{4}{*}{2.5} & \multirow{4}{*}{$\begin{array}{l}\text { Did you feel comfortable discussing HIV and } \\
\text { sexual health issues with that person? }\end{array}$} & \multicolumn{2}{|l|}{ Yes } & 1 & \\
\hline & & \multirow{2}{*}{\multicolumn{2}{|c|}{$\begin{array}{l}\text { No } \\
\text { There was no discussion of } \\
\text { these issues. }\end{array}$}} & 2 & \\
\hline & & & & 3 & \\
\hline & & Don't know & & 98 & \\
\hline 2.6 & Were you tested for HIV today? & Yes & & 1 & 2.11 \\
\hline & & No & & 2 & \\
\hline 2.7 & Do you intend to go for HIV testing? & Yes & & 1 & 2.10 \\
\hline & & No & & 2 & \\
\hline & & Don't know & & 98 & \\
\hline 2.8 & Why are you not interested in being tested? & Not ready & & 1 & \\
\hline & & $\begin{array}{l}\text { Fear to be in } \\
\text { infected bloc }\end{array}$ & cted with & 2 & \\
\hline & & Afraid of kn & ving status & 3 & \\
\hline & & Only have ol & partner & 4 & \\
\hline & & Already test & $1 /$ know status & 5 & 2.12 \\
\hline & & Other: & & 6 & \\
\hline & & Don't know & & 98 & \\
\hline 2.9 & Where do you plan to go for testing? & This facility & & 1 & 2.10 \\
\hline & & Other facility & & 2 & 2.10 \\
\hline & & Other: & & 3 & 2.10 \\
\hline 2.10 & Have you ever taken an HIV test before? & Yes & & 1 & \\
\hline & & No & & 2 & 2.14 \\
\hline & & Don't know & & 98 & 2.14 \\
\hline & & No response & & 99 & 2.14 \\
\hline 2.11 & Were you pregnant at the time you took the & Yes & & 1 & \\
\hline & test? & No & & 2 & \\
\hline 2.12 & Where did you go to get tested? & This facility & & 1 & \\
\hline & & Other facilit) & & 2 & \\
\hline & & Doctor & & 3 & \\
\hline & Interviewer: Mark all that apply. & \begin{tabular}{|l|l|} 
Work \\
\end{tabular} & & 4 & \\
\hline & & Other: & & 5 & \\
\hline
\end{tabular}




\begin{tabular}{|l|l|l|l|}
\hline 2.13 & $\begin{array}{l}\text { Have any of your sexual partners gone for } \\
\text { HIV testing? }\end{array}$ & Yes & 1 \\
\cline { 2 - 4 } & No & 2 \\
\hline \multirow{2}{*}{2.14} & $\begin{array}{l}\text { Do you intend to ask your sexual partner(s) to } \\
\text { go for an HIV test? }\end{array}$ & Yes & 1 \\
\cline { 2 - 4 } & No & 2 \\
\hline
\end{tabular}

3. Follow-up and referrals

\begin{tabular}{|c|c|c|c|c|}
\hline No. & QUESTIONS & CODING CATEGORIES & & GO TO \\
\hline \multirow[t]{3}{*}{3.1} & \multirow{3}{*}{$\begin{array}{l}\text { During your visit today, were you given any } \\
\text { information on follow-up care available for } \\
\text { you? }\end{array}$} & Yes & 1 & \\
\hline & & No & 2 & 3.5 \\
\hline & & Don't know & 98 & \\
\hline \multirow[t]{4}{*}{3.2} & \multirow[t]{4}{*}{ When will you go for a follow-up visit? } & Days from now: & 1 & \\
\hline & & Weeks from now: & 2 & \\
\hline & & Other: & 97 & \\
\hline & & Don't know & 98 & \\
\hline \multirow[t]{3}{*}{3.3} & \multirow{3}{*}{$\begin{array}{l}\text { During your visit today, were you given an } \\
\text { appointment date for a follow-up visit (return } \\
\text { date)? }\end{array}$} & Yes & 1 & \\
\hline & & No & 2 & 3.5 \\
\hline & & Don't know & 98 & \\
\hline \multirow[t]{12}{*}{3.4} & \multirow[t]{3}{*}{ For what services were you referred? } & ANC & 1 & \\
\hline & & PNC for the mother & 2 & \\
\hline & & Postnatal check-up for the baby & 3 & \\
\hline & \multirow[t]{9}{*}{ Interviewer: Mark all that apply. } & Follow-up on infant feeding & 4 & \\
\hline & & Child growth monitoring & 5 & \\
\hline & & Immunizations & 6 & \\
\hline & & STIs diagnosis and treatment & 7 & \\
\hline & & HIV/AIDS counseling and testing & 8 & \\
\hline & & Cervical cancer screening & 9 & \\
\hline & & Nutrition counseling & 10 & \\
\hline & & Other: & 11 & \\
\hline & & Don't know & 98 & \\
\hline \multirow[t]{12}{*}{3.5} & \multirow{3}{*}{$\begin{array}{l}\text { Can you please tell me what health services } \\
\text { you know this clinic offers? }\end{array}$} & ANC & 1 & \\
\hline & & Postnatal check-up for mother & 2 & \\
\hline & & Postnatal check-up for baby & 3 & \\
\hline & \multirow{9}{*}{ Interviewer: Mark all that apply. } & Follow-up on infant feeding & 4 & \\
\hline & & Child growth monitoring & 5 & \\
\hline & & Immunizations & 6 & \\
\hline & & Clinical care services & 7 & \\
\hline & & STIs diagnosis and treatment & 8 & \\
\hline & & HIV/AIDS counseling and testing & 9 & \\
\hline & & Cervical cancer screening & 10 & \\
\hline & & Other: & 11 & \\
\hline & & Don't know & 98 & \\
\hline
\end{tabular}

4. Reproductive history

\begin{tabular}{|c|c|c|c|c|}
\hline No. & QUESTIONS & CODING CATEGORIES & & GO TO \\
\hline 4.1 & $\begin{array}{l}\text { How many living children of your own do } \\
\text { you have? }\end{array}$ & Living children: & & \\
\hline \multirow[t]{3}{*}{4.2} & \multirow{3}{*}{$\begin{array}{l}\text { How long ago did your last pregnancy } \\
\text { end? }\end{array}$} & Number of days: & & \\
\hline & & Number of weeks: & & \\
\hline & & Number of months: & & \\
\hline \multirow[t]{4}{*}{4.3} & \multirow{4}{*}{$\begin{array}{l}\text { In the future, would you like to have more } \\
\text { children? }\end{array}$} & Yes & 1 & \\
\hline & & No & 2 & $\begin{array}{l}\text { next } \\
\text { section }\end{array}$ \\
\hline & & Other: & 3 & \\
\hline & & Don't know & 98 & \\
\hline \multirow[t]{3}{*}{4.4} & \multirow{3}{*}{$\begin{array}{l}\text { How long would you like to wait before } \\
\text { becoming pregnant again? }\end{array}$} & Number of months: & & \\
\hline & & Number of years: & & \\
\hline & & Other: & & \\
\hline
\end{tabular}


5. FP services received

No. QUESTIONS

CODING CATEGORIES

GO TO

Interviewer: Explain that you will now discuss the FP services the client has received at this facility.

Were you using a contraceptive method

when you came to the facility today?

5.2 Have you ever used any contraceptive method in the past?

5.3 Which method(s) have you ever used?

Interviewer: Mark all that apply.

\begin{tabular}{|l|c|}
\hline Yes & 1 \\
\hline No & 2 \\
\hline Yes & 1 \\
\hline No
\end{tabular}

5.9

No

Combined oral contraceptives

Minipills (progestin-only pills)

Emergency contraceptive pills

1

1

Progestin-only injectables (injection

every 2 or 3 months)

Monthly injectables

Jadelle implants

Implanon implants

Sinoplant (II) implants

IUD

IUS

\begin{tabular}{|l}
\hline Male condoms \\
\hline Female condoms \\
\hline
\end{tabular}

$2 \quad 5.4$

Female condom

Cervical caps

1

Female sterilization

Vasectomy

Fertility awareness methods

Withdrawal

LAM

Other:

2

3

4

5

7




\begin{tabular}{|c|c|c|c|c|}
\hline \multirow[t]{3}{*}{5.7} & \multirow{3}{*}{$\begin{array}{l}\text { Is (Are) this (these) the method(s) you want } \\
\text { to use? }\end{array}$} & Yes & 1 & 5.14 \\
\hline & & No & 2 & \\
\hline & & Don't know & 98 & 5.14 \\
\hline \multirow[t]{7}{*}{5.8} & \multirow{7}{*}{$\begin{array}{l}\text { Why did you not receive the method you } \\
\text { want to use? }\end{array}$} & Cost & 1 & \\
\hline & & Method not available & 2 & \\
\hline & & Partner objected method & 3 & \\
\hline & & Doctor said it was not good & \multirow{3}{*}{$\begin{array}{ll}4 & \text { for all } \\
5 & \text { responses }\end{array}$} & \\
\hline & & Doctor said I had contraindications & & \\
\hline & & Other: & & \\
\hline & & Don't know & 98 & \\
\hline \multirow[t]{21}{*}{5.9} & \multirow{21}{*}{$\begin{array}{l}\text { Which method(s) were you using before } \\
\text { coming to the facility today? }\end{array}$} & Combined oral contraceptives & 1 & \\
\hline & & Minipills (progestin-only pills) & 2 & \\
\hline & & Emergency contraceptive pills & 3 & \\
\hline & & $\begin{array}{l}\text { Progestin-only injectables (injection } \\
\text { every } 2 \text { or } 3 \text { months) }\end{array}$ & 4 & \\
\hline & & Monthly injectables & 5 & \\
\hline & & Jadelle implants & 6 & \\
\hline & & Implanon implants & 7 & \\
\hline & & Sinoplant (II) implants & 8 & \\
\hline & & IUD & 9 & \\
\hline & & IUS & 10 & \\
\hline & & Male condoms & 11 & \\
\hline & & Female condoms & 12 & \\
\hline & & Diaphragms & 13 & \\
\hline & & Cervical caps & 14 & \\
\hline & & Female sterilization & 15 & \\
\hline & & Vasectomy & 16 & \\
\hline & & Fertility awareness methods & 17 & \\
\hline & & Withdrawal & 18 & \\
\hline & & LAM & 19 & \\
\hline & & Other: & 20 & \\
\hline & & Don't know & 98 & \\
\hline \multirow[t]{3}{*}{5.10} & \multirow{3}{*}{$\begin{array}{l}\text { Have you had a problem, wanted to } \\
\text { changed methods, or wanted to stop FP? }\end{array}$} & Yes & 1 & \\
\hline & & No & 2 & $\begin{array}{l}\text { next } \\
\text { section }\end{array}$ \\
\hline & & Don't know & 98 & $\begin{array}{l}\text { next } \\
\text { section }\end{array}$ \\
\hline \multirow[t]{9}{*}{5.11} & \multirow{9}{*}{$\begin{array}{l}\text { What was the main problem you had or the } \\
\text { main reason you wanted to change or stop } \\
\text { FP? }\end{array}$} & Medical side-effects & 1 & \\
\hline & & Partner did not like the method & 2 & \\
\hline & & Pressure from others & 3 & \\
\hline & & Fear of infertility & 4 & \\
\hline & & Wanted pregnancy & 5 & \\
\hline & & Did not like the method & 6 & \\
\hline & & $\begin{array}{l}\text { Method unavailable/difficult to } \\
\text { obtain }\end{array}$ & 7 & \\
\hline & & Other: & 8 & \\
\hline & & Don't know & 98 & \\
\hline \multirow[t]{4}{*}{5.12} & \multirow[t]{4}{*}{ What are you now going to do about FP? } & Change to new method & 1 & \\
\hline & & Continue with same method & 2 & $\begin{array}{l}\text { next } \\
\text { section }\end{array}$ \\
\hline & & Stop using any method & 3 & $\begin{array}{l}\text { next } \\
\text { section }\end{array}$ \\
\hline & & Don't know & 98 & $\begin{array}{l}\text { next } \\
\text { section }\end{array}$ \\
\hline
\end{tabular}




\begin{tabular}{|c|c|c|c|c|}
\hline \multirow{21}{*}{$5.13 \mathrm{~V}$} & \multirow[t]{21}{*}{ Which method(s) will you now use? } & Combined oral contraceptives & 1 & \\
\hline & & Minipills (progestin-only pills) & 2 & \\
\hline & & Emergency contraceptive pills & 3 & \\
\hline & & Progestin-only injectables (injection & 4 & \\
\hline & & \begin{tabular}{|l} 
every 2 or 3 months) \\
Monthly iniectables
\end{tabular} & 5 & \\
\hline & & Jadelle implants & 6 & \\
\hline & & Implanon implants & 7 & \\
\hline & & Sinoplant (II) implants & 8 & \\
\hline & & IUD & 9 & \\
\hline & & IUS & 10 & \\
\hline & & Male condoms & 11 & \\
\hline & & Female condoms & 12 & \\
\hline & & Diaphragms & 13 & \\
\hline & & Cervical caps & 14 & \\
\hline & & Female Sterilization & 15 & \\
\hline & & Vasectomy & 16 & \\
\hline & & Fertility awareness methods & 17 & \\
\hline & & Withdrawal & 18 & \\
\hline & & LAM & 19 & \\
\hline & & Other: & 20 & \\
\hline & & Don't know & 98 & \\
\hline \multirow[t]{3}{*}{5.14} & \multirow{3}{*}{$\begin{array}{l}\text { Did a health provider explain to you how to } \\
\text { use the FP method you received? }\end{array}$} & Yes & 1 & \\
\hline & & No & 2 & \\
\hline & & Don't know & 98 & \\
\hline \multirow[t]{3}{*}{5.15} & \multirow{3}{*}{$\begin{array}{l}\text { Did a health provider describe the possible } \\
\text { side-effects or what kind of problems may } \\
\text { you experience while using this method? }\end{array}$} & Yes & 1 & \\
\hline & & No & 2 & \\
\hline & & Don't know & 98 & \\
\hline \multirow[t]{3}{*}{5.16} & \multirow{3}{*}{$\begin{array}{l}\text { Did a health provider explain what to do } \\
\text { if you experience any problems or side- } \\
\text { effects? }\end{array}$} & Yes & 1 & \\
\hline & & No & 2 & \\
\hline & & Don't know & 98 & \\
\hline \multirow[t]{3}{*}{5.17} & \multirow{3}{*}{$\begin{array}{l}\text { Did the provider mention any other method } \\
\text { to you? }\end{array}$} & Yes & 1 & \\
\hline & & No & 2 & $\begin{array}{l}\text { next } \\
\text { section }\end{array}$ \\
\hline & & Don't know & 98 & $\begin{array}{l}\text { next } \\
\text { section }\end{array}$ \\
\hline \multirow[t]{21}{*}{5.18} & \multirow[t]{21}{*}{ Which methods were discussed with you? } & Combined oral contraceptives & 1 & \\
\hline & & Minipills (progestin-only pills) & 2 & \\
\hline & & Emergency Contraceptive Pills & 3 & \\
\hline & & $\begin{array}{l}\text { Progestin-only injectables (injection } \\
\text { every } 2 \text { or } 3 \text { months) }\end{array}$ & 4 & \\
\hline & & Monthly injectables & 5 & \\
\hline & & Jadelle implants & 6 & \\
\hline & & \begin{tabular}{|l} 
Implanon implants \\
\end{tabular} & 7 & \\
\hline & & Sinoplant (II) implants & 8 & \\
\hline & & IUD & 9 & \\
\hline & & IUS & 10 & \\
\hline & & Male condoms & 11 & \\
\hline & & Female condoms & 12 & \\
\hline & & Diaphragms & 13 & \\
\hline & & Cervical caps & 14 & \\
\hline & & Female sterilization & 15 & \\
\hline & & Vasectomy & 16 & \\
\hline & & Fertility awareness methods & 17 & \\
\hline & & Withdrawal & 18 & \\
\hline & & LAM & 19 & \\
\hline & & Other: & 20 & \\
\hline & & Don't know & 98 & \\
\hline
\end{tabular}


6. Client's feelings about the quality of FP services

\begin{tabular}{|c|c|c|c|c|}
\hline No. & QUESTIONS & CODING CATEGORIES & & GO TO \\
\hline \multirow{2}{*}{6.1} & \multirow{2}{*}{$\begin{array}{l}\text { Do you feel that you received the information } \\
\text { that you wanted today about FP? }\end{array}$} & Yes & 1 & \\
\hline & & No & 2 & \\
\hline \multirow[t]{3}{*}{6.2} & \multirow{3}{*}{$\begin{array}{l}\text { Did you feel that your FP consultation was too } \\
\text { short, too long, or about the right amount of } \\
\text { time? }\end{array}$} & Too short & 1 & \\
\hline & & Too long & 2 & \\
\hline & & About the right amount of time & 3 & \\
\hline \multirow[t]{2}{*}{6.3} & \multirow{2}{*}{$\begin{array}{l}\text { In your opinion, did you have enough privacy } \\
\text { during the consultation today? }\end{array}$} & Yes & 1 & \\
\hline & & No & 2 & 7.5 \\
\hline
\end{tabular}

\section{Condom use}

\begin{tabular}{|c|c|c|c|}
\hline No. & QUESTIONS & CODING CATEGORIES & GO TO \\
\hline \multirow[t]{2}{*}{7.1} & \multirow{2}{*}{ Have you ever used a condom? } & Yes & 7.3 \\
\hline & & No & 2 \\
\hline \multirow[t]{7}{*}{7.2} & \multirow{3}{*}{$\begin{array}{l}\text { What are the reasons you have never used a } \\
\text { condom before? }\end{array}$} & I have never had sex. & \multirow{7}{*}{$\begin{array}{l}\text { next } \\
\text { section } \\
\text { for all } \\
\text { - questions }\end{array}$} \\
\hline & & I don't know how to use them. & \\
\hline & & I am married/a faithful partner. & \\
\hline & \multirow{4}{*}{ Interviewer: Mark all that apply. } & I am afraid it will burst. & \\
\hline & & I do not like them. & \\
\hline & & My partner doesn't like them. & \\
\hline & & Other: & \\
\hline \multirow[t]{3}{*}{7.3} & \multirow{3}{*}{$\begin{array}{l}\text { In the last month, how often did you use } \\
\text { condoms when you had sex? }\end{array}$} & Never & 1 \\
\hline & & Sometimes & 2 \\
\hline & & Always & 3 \\
\hline \multirow[t]{3}{*}{7.4} & \multirow{3}{*}{$\begin{array}{l}\text { The last time you had sex, did you use a } \\
\text { condom? }\end{array}$} & Yes & 1 \\
\hline & & No & 2 \\
\hline & & Don't Know & 98 \\
\hline \multirow[t]{4}{*}{7.5} & \multirow[t]{4}{*}{ Why do you use condoms? } & To protect against HIV/STIs & 1 \\
\hline & & To prevent pregnancies & 2 \\
\hline & & I'm on treatment. & 3 \\
\hline & & Other: & 4 \\
\hline
\end{tabular}

\section{Knowledge of STIs and HIV}

\begin{tabular}{|c|c|c|c|c|}
\hline No. & QUESTIONS & CODING CATEGORIES & & GO TO \\
\hline \multirow[t]{3}{*}{8.1} & \multirow{3}{*}{$\begin{array}{l}\text { As far as you know, are there any diseases that } \\
\text { can be transmitted through sexual intercourse? }\end{array}$} & Yes & 1 & \\
\hline & & No & 2 & 8.4 \\
\hline & & Don't know & 98 & 8.4 \\
\hline \multirow[t]{11}{*}{8.2} & \multirow{3}{*}{$\begin{array}{l}\text { If a woman has an STI, what symptoms might } \\
\text { she have? }\end{array}$} & No symptoms & 1 & \\
\hline & & Lower abdominal pain & 2 & \\
\hline & & $\begin{array}{l}\text { Unusual or abnormal vaginal } \\
\text { discharge }\end{array}$ & 3 & \\
\hline & \multirow[t]{8}{*}{ Interviewer: Mark all that apply. } & Burning pain or urination & 4 & \\
\hline & & Genital ulcers/sores & 5 & \\
\hline & & Swelling in the groin area & 6 & \\
\hline & & Itching & 7 & \\
\hline & & Pain during intercourse & 8 & \\
\hline & & Genital warts & 9 & \\
\hline & & Other: & 10 & \\
\hline & & on't kno & 98 & \\
\hline
\end{tabular}




\begin{tabular}{|c|c|c|c|c|}
\hline \multirow[t]{11}{*}{8.3} & \multirow{3}{*}{$\begin{array}{l}\text { If a man has an STI, what symptoms might he } \\
\text { have? }\end{array}$} & No symptoms & 1 & \\
\hline & & Lower abdominal pain & 2 & \\
\hline & & $\begin{array}{l}\text { Unusual or abnormal discharge } \\
\text { from the penis }\end{array}$ & 3 & \\
\hline & \multirow[t]{8}{*}{ Interviewer: Mark all that apply. } & Burning pain on urination & 4 & \\
\hline & & Genital ulcers/sores & 5 & \\
\hline & & Swelling in the groin area & 6 & \\
\hline & & Itching & 7 & \\
\hline & & Pain during intercourse & 8 & \\
\hline & & Genital warts & 9 & \\
\hline & & Other: & 10 & \\
\hline & & Don't know & 98 & \\
\hline \multirow[t]{3}{*}{8.4} & \multirow{3}{*}{$\begin{array}{l}\text { Have you ever heard of HIV or the disease } \\
\text { called AIDS? }\end{array}$} & Yes & 1 & \\
\hline & & No & 2 & 8.10 \\
\hline & & Don't know & 98 & 8.10 \\
\hline \multirow[t]{3}{*}{8.5} & \multirow{3}{*}{$\begin{array}{l}\text { Is it possible to have an STI, including HIV/AIDS, } \\
\text { and still look healthy? }\end{array}$} & Yes & 1 & \\
\hline & & No & 2 & \\
\hline & & Don't know & 98 & \\
\hline \multirow[t]{3}{*}{8.6} & \multirow{3}{*}{$\begin{array}{l}\text { What do you think are the chances that you } \\
\text { personally may become infected with an STI, } \\
\text { including HIV? }\end{array}$} & No chance & 1 & \\
\hline & & Some chance & 2 & \\
\hline & & High chance & 98 & \\
\hline \multirow[t]{8}{*}{8.7} & \multirow[t]{8}{*}{ Why do you think you are not at risk? } & $\begin{array}{l}\text { I believe my partners are not } \\
\text { infected. }\end{array}$ & 1 & \multirow{8}{*}{$\begin{array}{l}\text { - } 8.9 \\
\text { for all } \\
\text { questions }\end{array}$} \\
\hline & & I abstain from sex. & 2 & \\
\hline & & I always use a condom. & 3 & \\
\hline & & $\begin{array}{l}\text { I use condoms with partners I don't } \\
\text { trust. }\end{array}$ & 4 & \\
\hline & & I only have one partner. & 5 & \\
\hline & & My partner and I are faithful. & 6 & \\
\hline & & Other: & 7 & \\
\hline & & Don't know & 98 & \\
\hline \multirow[t]{9}{*}{8.8} & \multirow[t]{9}{*}{ Why do you think you are at risk? } & I do not use condoms. & 1 & \\
\hline & & I have more than one partner. & 2 & \\
\hline & & $\begin{array}{l}\text { My partner has more than one } \\
\text { partner. }\end{array}$ & 3 & \\
\hline & & I have had an STI previously. & 4 & \\
\hline & & My partner has symptoms. & 5 & \\
\hline & & My partner is an IV drug user. & 6 & \\
\hline & & I am an IV drug user. & 7 & \\
\hline & & Other: & 8 & \\
\hline & & Don't know & 98 & \\
\hline \multirow[t]{7}{*}{8.9} & \multirow{7}{*}{$\begin{array}{l}\text { Do you know which methods exist to prevent } \\
\text { HIV? }\end{array}$} & Use condoms & 1 & \\
\hline & & Fidelity to one partner & 2 & \\
\hline & & Encourage partner to remain & 3 & \\
\hline & & \begin{tabular}{|l|} 
Talthitul \\
Abstinence \\
\end{tabular} & 4 & \\
\hline & & Avoid sharing razors/needles & 5 & \\
\hline & & Other: & 6 & \\
\hline & & Don't know & 98 & \\
\hline \multirow[t]{3}{*}{8.10} & \multirow{3}{*}{$\begin{array}{l}\text { Please tell me which FP methods protect both } \\
\text { men and women from STls, including HIV/AIDS? }\end{array}$} & Condoms & 1 & \\
\hline & & Other: & 2 & \\
\hline & & \begin{tabular}{|l|} 
Don't know \\
\end{tabular} & 98 & \\
\hline \multirow[t]{4}{*}{8.11} & \multirow{4}{*}{$\begin{array}{l}\text { Do you know where someone in your community } \\
\text { could go for an HIV test? }\end{array}$} & Yes, about HIV & 1 & \\
\hline & & Yes, about STIs & 2 & \\
\hline & & No & 3 & \\
\hline & & Don't know & 98 & \\
\hline
\end{tabular}


9. IEC materials

\begin{tabular}{|c|c|c|c|c|}
\hline \multirow{3}{*}{\begin{tabular}{|l|} 
No. \\
9.1
\end{tabular}} & QUESTIONS & \multicolumn{2}{|l|}{ CODING CATEGORIES } & $\mathrm{GO}$ TO \\
\hline & \multirow{2}{*}{$\begin{array}{l}\text { At any time during the consultation, did you } \\
\text { receive any information materials from this } \\
\text { facility? }\end{array}$} & Yes & 1 & \\
\hline & & No & 2 & $\begin{array}{r}\text { Dext } \\
\text { section }\end{array}$ \\
\hline \multirow[t]{9}{*}{9.2} & \multirow{3}{*}{$\begin{array}{l}\text { What were they about? The content of the } \\
\text { information materials? }\end{array}$} & FP & 1 & \\
\hline & & ANC & 2 & \\
\hline & & PNC & 3 & \\
\hline & \multirow{6}{*}{ Interviewer: Mark all that apply. } & HIV/AIDS & 4 & \\
\hline & & Other STIs & 5 & \\
\hline & & PMTCT & 6 & \\
\hline & & Child welfare & 7 & \\
\hline & & Other: & 8 & \\
\hline & & Don't know & 98 & \\
\hline
\end{tabular}

10. Satisfaction with services

\begin{tabular}{|c|c|c|c|c|}
\hline No. & QUESTIONS & CODING & TEGORIES & \\
\hline 10.1 & How long did you wait between the time you arrived at this & Minutes: & & \\
\hline & facility and the time you were able to see a provider for & Hours: & & \\
\hline & the consultation? & $\begin{array}{l}\text { Saw prov } \\
\text { immediat }\end{array}$ & & 97 \\
\hline & & Don't kno & & 98 \\
\hline 10.2 & Do you the think the time you waited was too long, & Too long & & 1 \\
\hline & reasonable, or short? & Reasonab & & 2 \\
\hline & & Short & & 3 \\
\hline & & Don't kno & & 98 \\
\hline 10.3 & $\begin{array}{l}\text { Interviewer: Explain that you will now ask about some } \\
\text { common experiences clients have at health facilities. As you } \\
\text { mention each one, ask they client whether she was satisfied, } \\
\text { dissatisfied, or undecided about any of the services received } \\
\text { today. }\end{array}$ & Satisfied & Dissatisfied & Undecided \\
\hline & $\begin{array}{l}\text { 1) Ability to discuss problems or concerns about your care } \\
\text { with the providers }\end{array}$ & 1 & 2 & 3 \\
\hline & $\begin{array}{l}\text { 2) Amount of explanation the providers gave to you about } \\
\text { a problem or treatment }\end{array}$ & 1 & 2 & 3 \\
\hline & 3) Quality of examination and treatment provided & 1 & 2 & 3 \\
\hline & $\begin{array}{l}\text { 4) Visual privacy during examination (that other clients } \\
\text { could not see you) }\end{array}$ & 1 & 2 & 3 \\
\hline & $\begin{array}{l}\text { 5) Auditory privacy during discussion (that other clients } \\
\text { could not hear you) }\end{array}$ & 1 & 2 & 3 \\
\hline & 6) Cleanliness of this facility & 1 & 2 & 3 \\
\hline & 7) How the clinic staff treated you & 1 & 2 & 3 \\
\hline 10.4 & Would you strongly, not strongly, or never recommend a & Strongly $r$ & mmend & 1 \\
\hline & friend to this facility for FP services? & $\begin{array}{l}\text { Recommer } \\
\text { strongly }\end{array}$ & but not & 2 \\
\hline & & Never rec & mend & 3 \\
\hline & & Don't knor & & 98 \\
\hline
\end{tabular}

\section{Male involvement}

\begin{tabular}{|c|c|c|c|c|}
\hline \multirow{4}{*}{\begin{tabular}{|l|} 
No. \\
11.1
\end{tabular}} & QUESTIONS & \multicolumn{2}{|l|}{ CODING CATEGORIES } & \multirow{2}{*}{$\frac{\mathrm{GO} T O}{11.4}$} \\
\hline & \multirow[t]{3}{*}{ Did your current partner accompany you to this visit? } & Yes & 1 & \\
\hline & & No & 2 & \\
\hline & & Don't know & 98 & \\
\hline 11.2 & During this visit, did a health provider advise you to & Yes & 1 & \\
\hline & encourage your partner to accompany you to your & No & 2 & \\
\hline & FP visits? & Don't know & 98 & \\
\hline 11.3 & Would you like your partner to receive information & Yes & 1 & \\
\hline & about FP methods? & No & 2 & \\
\hline & & Don't know & 98 & \\
\hline 11.4 & Has your current partner ever beaten or insulted & Yes & 1 & \\
\hline & you? & No & 2 & 11.6 \\
\hline & & No response & 99 & 11.6 \\
\hline
\end{tabular}




\begin{tabular}{|l|l|l|c|}
\hline 11.5 & $\begin{array}{l}\text { Have you talked about this issue to a health } \\
\text { provider? }\end{array}$ & Yes & 1 \\
\cline { 2 - 3 } & No & 2 \\
\hline 11.6 & $\begin{array}{l}\text { Would you like you and your partner to talk with } \\
\text { somebody at this clinic about how both of you can } \\
\text { get protection from HIV infection? }\end{array}$ & Yes & 1 \\
\cline { 2 - 3 } & No & 2 \\
\cline { 2 - 3 } & Don't know & 98 \\
\hline
\end{tabular}

\section{Costs}

\begin{tabular}{|c|c|c|c|}
\hline \multirow{9}{*}{\begin{tabular}{|l|} 
No. \\
12.1
\end{tabular}} & QUESTIONS & \multicolumn{2}{|l|}{ CODING CATEGORIES } \\
\hline & \multirow{8}{*}{$\begin{array}{l}\text { How much did you pay for all services or } \\
\text { treatments you received at this facility today? } \\
\text { How much did you pay for travel? }\end{array}$} & Fees for client card: & \\
\hline & & Fees for consultation: & \\
\hline & & Fees for laboratory tests: & \\
\hline & & Fees for methods: & \\
\hline & & Other: & \\
\hline & & I did not pay anything at the clinic. & \\
\hline & & Travel: & \\
\hline & & Total: & \\
\hline \multirow[t]{4}{*}{12.2} & \multirow{4}{*}{$\begin{array}{l}\text { What do you think of the costs of your } \\
\text { treatment? }\end{array}$} & They were ok. & 1 \\
\hline & & Too much & 2 \\
\hline & & Other: & 3 \\
\hline & & Don't know & 98 \\
\hline
\end{tabular}

\section{Accessibility}

\begin{tabular}{|c|c|c|c|}
\hline No. & QUESTIONS & CODING CATEGORIES & \\
\hline \multirow[t]{7}{*}{13.1} & \multirow{3}{*}{$\begin{array}{l}\text { By what means of transport did you get to the clinic } \\
\text { today? }\end{array}$} & Taxi & 1 \\
\hline & & Bus & 2 \\
\hline & & Train & 3 \\
\hline & \multirow{4}{*}{ Interviewer: Mark all that apply. } & Private car & 4 \\
\hline & & Bicycle & 5 \\
\hline & & Walk & 6 \\
\hline & & Other: & 7 \\
\hline \multirow[t]{2}{*}{13.2} & \multirow{2}{*}{$\begin{array}{l}\text { Approximately how long did it take you to get to the } \\
\text { clinic today? }\end{array}$} & Hours: & \\
\hline & & Minutes: & \\
\hline \multirow[t]{2}{*}{13.3} & \multirow{2}{*}{$\begin{array}{l}\text { Are the hours of service at this facility appropriate } \\
\text { for you? }\end{array}$} & Yes & 1 \\
\hline & & No & 2 \\
\hline 13.4 & Why not? & & \\
\hline
\end{tabular}

\section{Demographics}

\begin{tabular}{|c|c|c|c|}
\hline No. & QUESTIONS & CODING CATEGORIES & \\
\hline 14.1 & How old are you? & Age in years: & \\
\hline \multirow[t]{5}{*}{14.2} & \multirow[t]{5}{*}{ What is your current marital status? } & Married, monogamous & 1 \\
\hline & & Married, polygamous & 2 \\
\hline & & Cohabiting/living with partner & 3 \\
\hline & & Single, never married & 4 \\
\hline & & Divorced/separated/widowed & 5 \\
\hline \multirow[t]{5}{*}{14.3} & \multirow{5}{*}{$\begin{array}{l}\text { What is the highest level of school you } \\
\text { attended? }\end{array}$} & Did not attend formal school & 1 \\
\hline & & Primary & 2 \\
\hline & & Secondary & 3 \\
\hline & & Tertiary & 4 \\
\hline & & Other: & 5 \\
\hline
\end{tabular}




\section{Provider interview}

\section{INSTRUCTIONS FOR THE}

INTERVIEWERS: Interview all health facility staff who are responsible for providing FP services and HIV/STI prevention and detection services to FP clients. Please interview staff at the end of the working day or during their breaks. Make it clear that you are seeking their assistance in finding ways of improving the functioning and quality of the services offered by facilities in general and are not evaluating the performance of the facility or of them individually. For each item, circle the code of the adequate response or describe, as appropriate. Read the following greeting when you meet with each provider that you will interview.
GREETING: Good morning. My name is , and I work for We are currently doing a study about the way that family planning services are being integrated with HIV and STI prevention and detection services and the issues that arise with integration. As a part of this study, we are interviewing all health providers who participate in FP services and HIV and STI services for family planning clients. These interviews are not to evaluate individual facilities or providers. We are visiting a number of facilities. All the information you give me will be confidential, and no one will know what you said. I will not record your name in the questionnaire, and there will be no way in which the responses you give me can be directly linked to you. They will all be confidential.

\section{Facility identification}

\begin{tabular}{|c|c|c|c|}
\hline No. & QUESTIONS & \multicolumn{2}{|l|}{ CODING CATEGORIES } \\
\hline 1.1 & Date of interview & \multicolumn{2}{|l|}{ (Day/ Month/ Year) } \\
\hline 1.2 & Facility name & & \\
\hline 1.3 & City or locality & & \\
\hline \multirow[t]{7}{*}{1.4} & \multirow[t]{7}{*}{ Type of facility } & Hospital & 1 \\
\hline & & Health center with maternity ward & 2 \\
\hline & & Health center without maternity ward & 3 \\
\hline & & Health post with maternity ward & 4 \\
\hline & & Health post without maternity ward & 5 \\
\hline & & Dispensary & 6 \\
\hline & & Other: & 7 \\
\hline \multirow[t]{4}{*}{1.5} & \multirow[t]{4}{*}{ Type of sector } & Government & 1 \\
\hline & & NGO & 2 \\
\hline & & Private & 3 \\
\hline & & Other: & 4 \\
\hline \multirow[t]{4}{*}{1.6} & \multirow[t]{4}{*}{ Result of the interview } & Complete & 1 \\
\hline & & Incomplete & 2 \\
\hline & & Refused & 3 \\
\hline & & Other: & 4 \\
\hline
\end{tabular}


2. Demographics and professional experience

\begin{tabular}{|c|c|c|c|}
\hline \multirow{2}{*}{\begin{tabular}{|l} 
No. \\
2.1
\end{tabular}} & QUESTIONS & \multicolumn{2}{|l|}{ CODING CATEGORIES } \\
\hline & \multirow{2}{*}{$\begin{array}{l}\text { Sex } \\
\text { Interviewer: Please mark. }\end{array}$} & Male & 1 \\
\hline & & Female & 2 \\
\hline 2.2 & How old are you? & Age in years: & \\
\hline \multirow[t]{10}{*}{2.3} & \multirow{10}{*}{ What is your current technical qualification? } & Specialist doctor & 1 \\
\hline & & General doctor & 2 \\
\hline & & Social service doctor & 3 \\
\hline & & Intern MD student & 4 \\
\hline & & Nurse-midwife & 5 \\
\hline & & Professional nurse & 6 \\
\hline & & Auxiliary nurse & 7 \\
\hline & & Nursing student & 8 \\
\hline & & Social worker & 9 \\
\hline & & Other: & \\
\hline 2.4 & How many years ago did you qualify? & Years: & \\
\hline \multirow[t]{2}{*}{2.5} & \multirow[t]{2}{*}{ How long have you been working at this facility? } & Months: & \\
\hline & & Years: & \\
\hline \multirow[t]{5}{*}{2.6} & \multirow[t]{5}{*}{ In which unit or department are you currently working? } & FP & 1 \\
\hline & & $\mathrm{MCH}$ & 2 \\
\hline & & HIV prevention and detection & 3 \\
\hline & & STI prevention and detection & 4 \\
\hline & & Other: & 5 \\
\hline \multirow[t]{15}{*}{2.7} & \multirow{3}{*}{$\begin{array}{l}\text { What services do you personally provide at this } \\
\text { facility? }\end{array}$} & FP counseling & 1 \\
\hline & & Contraceptives & 2 \\
\hline & & ANC & 3 \\
\hline & \multirow{12}{*}{ Interviewer: Mark all that apply. } & Delivery & 4 \\
\hline & & Postnatal care & 5 \\
\hline & & $\begin{array}{l}\text { Treatment of abortion } \\
\text { complications }\end{array}$ & 6 \\
\hline & & HIV/AIDS counseling & 7 \\
\hline & & HIV/AIDS testing & 8 \\
\hline & & HIV/AIDS treatment and care & 9 \\
\hline & & STI services & 10 \\
\hline & & Child immunization & 11 \\
\hline & & Child growth monitoring & 12 \\
\hline & & Curative services for women & 13 \\
\hline & & Curative services for children & 14 \\
\hline & & Other: & 15 \\
\hline
\end{tabular}

\section{Integration of FP and HIV/STI prevention and detection}

\begin{tabular}{|c|c|c|c|c|c|c|c|c|}
\hline \multirow{10}{*}{$\frac{\text { No. }}{3.1}$} & \multicolumn{2}{|l|}{ QUESTIONS } & \multicolumn{5}{|c|}{ CODING CATEGORIES } & GO TO \\
\hline & \multirow{2}{*}{\multicolumn{2}{|c|}{$\begin{array}{l}\text { Interviewer: (a) During your in-service professional } \\
\text { training, have you ever received training in [read } 1 \\
\text { to 6]? For every positive response, ask: (b) Have you } \\
\text { received training in [... in the past year? }\end{array}$}} & \multicolumn{2}{|c|}{$\begin{array}{l}\text { (a) Ever receivec } \\
\text { training }\end{array}$} & \multicolumn{3}{|c|}{$\begin{array}{l}\text { (b) Received } \\
\text { training last year }\end{array}$} & \\
\hline & & & & No & \multirow{2}{*}{ Yes } & \multicolumn{2}{|l|}{ No } & \\
\hline & \multicolumn{2}{|l|}{ 1) FP counseling techniques } & 1 & 2 & & \multicolumn{2}{|c|}{2} & \\
\hline & \multicolumn{2}{|l|}{ 2) HIV counseling in general } & 1 & 2 & 1 & \multicolumn{2}{|c|}{2} & \\
\hline & \multicolumn{2}{|l|}{ 3) HIV pre-test counseling } & 1 & 2 & 1 & \multicolumn{2}{|c|}{2} & \\
\hline & \multicolumn{2}{|l|}{ 4) HIV testing and post-test counseling } & 1 & 2 & 1 & \multicolumn{2}{|c|}{2} & \\
\hline & \multicolumn{2}{|l|}{ 5) STI counseling } & 1 & 2 & 1 & \multicolumn{2}{|c|}{2} & \\
\hline & \multicolumn{2}{|l|}{ 6) STI syndromic detection } & 1 & 2 & 1 & \multicolumn{2}{|c|}{2} & \\
\hline & \multicolumn{2}{|l|}{ Other: } & 1 & 2 & 1 & \multicolumn{2}{|c|}{2} & \\
\hline \multirow[t]{4}{*}{3.2} & \multirow{4}{*}{$\begin{array}{l}\text { During FP consultations, do you provide } \\
\text { information about HIV/AIDS or about STIs? }\end{array}$} & \multicolumn{4}{|c|}{ Yes, always } & & 1 & \\
\hline & & \multirow{2}{*}{\multicolumn{4}{|c|}{$\begin{array}{l}\text { Yes, sometimes } \\
\text { Yes, only in client asks }\end{array}$}} & & 2 & \\
\hline & & \multirow{2}{*}{\multicolumn{4}{|c|}{$\begin{array}{l}\text { Yes, only in client asks } \\
\text { No }\end{array}$}} & & 3 & \\
\hline & & & & & & & 4 & 3.8 \\
\hline
\end{tabular}




\begin{tabular}{|c|c|c|c|c|c|}
\hline \multirow{7}{*}{3.3} & \multicolumn{2}{|l|}{ During FP consultations do you: } & Yes & No & \\
\hline & \multicolumn{2}{|l|}{ 1) Discuss STI and/or HIV risk factors with the client? } & 1 & & 2 \\
\hline & \multicolumn{2}{|l|}{ 2) Give clients information on symptoms of STIs? } & 1 & & 2 \\
\hline & \multicolumn{2}{|l|}{ 3) Tell clients that STIs can be asymptomatic? } & 1 & & 2 \\
\hline & \multicolumn{2}{|l|}{ 4) Discuss STI/HIV prevention methods? } & 1 & & 2 \\
\hline & \multirow{2}{*}{\multicolumn{2}{|c|}{$\begin{array}{l}\text { 5) Tell clients where they can obtain STI/HIV information? } \\
\text { 6) Tell clients where they can obtain STI/HIV tests? }\end{array}$}} & 1 & & 2 \\
\hline & & & 1 & & 2 \\
\hline \multirow[t]{8}{*}{3.4} & \multicolumn{2}{|c|}{$\begin{array}{l}\text { Which methods to prevent STI/HIV transmission do you discuss with } \\
\text { clients? }\end{array}$} & \multirow[b]{2}{*}{ Yes } & \multirow{2}{*}{\multicolumn{2}{|c|}{ No }} \\
\hline & \multicolumn{2}{|l|}{ Interviewer: Don't read. } & & & \\
\hline & \multicolumn{2}{|l|}{ 1) Consistent condom use } & 1 & & 2 \\
\hline & \multicolumn{2}{|l|}{ 2) Abstinence } & 1 & & 2 \\
\hline & \multicolumn{2}{|l|}{ 3) Monogamy } & 1 & & 2 \\
\hline & \multicolumn{2}{|l|}{ 4) Partner monogamy } & 1 & & 2 \\
\hline & \multicolumn{2}{|l|}{ 5) Knowing your partner's status } & 1 & & 2 \\
\hline & \multicolumn{2}{|l|}{ 6) Knowing your own status } & 1 & \multicolumn{2}{|r|}{2} \\
\hline \multirow[t]{2}{*}{3.5} & \multirow{2}{*}{$\begin{array}{l}\text { Do you personally provide HIV C\&T to FP } \\
\text { clients? }\end{array}$} & \multicolumn{2}{|l|}{ Yes } & 1 & \\
\hline & & No & & 2 & 3.8 \\
\hline \multirow[t]{10}{*}{3.6} & \multirow{3}{*}{$\begin{array}{l}\text { What are the main activities you follow when } \\
\text { giving HIV C\&T services to FP clients? }\end{array}$} & \multicolumn{2}{|c|}{ Discuss HIV/STI risk factors. } & 1 & \\
\hline & & Discuss $\mathrm{H}$ & oms. & 2 & \\
\hline & & Discuss $\mathrm{H}$ & tion methods. & 3 & \\
\hline & Interviewer: Mark all the relevant options. & Give info & ow to use a & 4 & \\
\hline & & \begin{tabular}{|l} 
Condom. \\
Fmphasi-
\end{tabular} & ince of being & 5 & \\
\hline & & $\begin{array}{l}\text { Emprisiz } \\
\text { tested. }\end{array}$ & ince of being & & \\
\hline & & Discuss $\mathrm{W}$ & an tell them. & 6 & \\
\hline & & Explain & dow period. & 7 & \\
\hline & & Give info & t where to & 8 & \\
\hline & & Other: & & 9 & \\
\hline 3.7 & What are the main difficulties you have had in & Lack of s & & 1 & \\
\hline & this facility in providing HIV/STI services to FP & Lack of & onnel & 2 & \\
\hline & clients in the last 3 months? & Lack of & & 3 & \\
\hline & & Failures & & 4 & \\
\hline & & Inapprop & & 5 & \\
\hline & & Do not fe & trained & 6 & \\
\hline & & Not enou & unsel clients & 7 & \\
\hline & & Other: & & 8 & \\
\hline 3.8 & Are there any written guidelines in this facility & Yes, for & STI & 1 & \\
\hline & for providing STI/HIV services to FP clients? & Yes, for 1 & & 2 & \\
\hline & & Yes, for & & 3 & \\
\hline & & No & & 4 & end \\
\hline & & Don't knc & & 98 & end \\
\hline 3.9 & How well do you know the guidelines for & Very we & & 1 & \\
\hline & providing STI/HIV? & Fairly we & & 2 & \\
\hline & & Not well & & 3 & \\
\hline
\end{tabular}


